\title{
Suomen kulutusverotuksen \\ historia ja veneveron haaksirikko
}


Esko Linnakangas

\section{Suomen kulutus- verotuksen historia ja veneveron haaksirikko}


Copyright (C) 2017 Esko Linnakangas

ISBN 978-952-93-8835-6

Kansi ja sivunvalmistus: NotePad

Kannen kuva: Taija Haapaniemi

Kirjapaino: Grano Oy

Helsinki 2017 


\section{Alkusanat}

Vuotuinen ajoneuvovero Suomessa alkoi 1920-luvulla. Ensimmäistä ajoneuvoverolakia koskevaa esitystä käsiteltäessä pohdittiin, tosin huonolla menestyksellä, eikö veron alaisiksi olisi autojen lisäksi säädettävä huvitarkoituksiin käytetyt moottoriveneet.

Helsingin yliopiston kansantaloustieteen professori $\mathrm{Ilm}$. Kovero totesi vuonna 1932 kirjassaan Ylellisyysverotus:

"Ylellisyysverotuksemme lisääminen olisi etusijassa suotavaa [--] muun verotuksen (tarpeellisempaan kulutukseen kohdistuvan ja rikkausverotuksen) lieventämiseksi. Mitä erikoisesti rikkausverotukseen tulee, on se meillä nykyisessä korkeudessaan, kun myöskin kunnallisverotus on otettava huomioon, suureen pääomaköyhyyteemme katsoen epäilemättä arveluttava. Mikäli kuitenkaan verotusta ei muuten voida järjestää tarkoituksenmukaisella tavalla, on välttämätöntä ryhtyä supistamaan julkisten talouksiemme suuresti kasvaneita menoja."

Kovero siis suositteli rikkausverojen tilalle ylellisyysverotuksen lisäämistä. Uusina mahdollisina verokohteina hän mainitsi muun muassa nopeakulkuiset huvialukset. Esitys ei ottanut tuulta.

Veneveron säätäminen valtion verotulojen lisäämiseksi otettiin pääministeri Juha Sipilän hallituksen ohjelmaan vuonna 2015. Valtiovarainministeriössä vuoden 2016 lopussa valmistunut ja lausunnolle lähetetty veromalli toi mieleen 1700-luvun pönkkähameveron ja monet muutkin jo verohistoriaan siirtyneet verot. Veroluonnoksen saama palaute oli erittäin kielteinen. Hallitus päättikin helmikuussa 2017 luopua veneverohankkeesta, kuten myös samaan aikaan valmistellusta moottoripyörien ajoneuvoverohankkeesta. 
Vuotuista veneveroa on Suomessa mietitty pian sata vuotta, mutta vieläkään sellaista ei meillä ole. Siihen, ettei veneveroa ole säädetty, täytyy olla syynsä. Tässä kirjassa selvitetään, mitkä nuo syyt ovat ja onko jonkinlainen venevero vielä mahdollinen sekä mitä parempia keinoja valtion verotulojen lisäämiseen on. Kulutusverotuksen historialla on tässä tutkimuksessa päärooli.

Teoksessa keskitytään varsinkin erityisiin kulutusveroihin ja veneisiin. Autojen ja moottoripyörien verokohtelua selvitetään tarkemmin juhlakirjassa "Autoveron saattohoito ja tieliikenneverotuksen kehittäminen", joka ilmestyy vuodenvaihteessa 2017/2018 autoveromme täyttäessä 60 vuotta.

Oma kustannustoimittajani Taija Haapaniemi on antanut minulle korvaamatonta apua ja iloa tässäkin omakustanneprojektissa.

Kirja on tilattavissa allekirjoittaneelta.

Kesäkuun 15. päivänä 2017

(huvimatkalla Varsovassa, jossa julkinen liikenne on ilmaista 70 vuotta täyttäneille)

\section{Esko Linnakangas}

finanssioikeuden emeritusprofessori

sähköposti: esko.linnakangas@professori.fi 


\section{Sisällys}

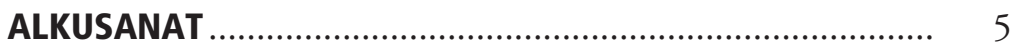

1 KULUTUSVEROTUKSEN HISTORIA .................................... 13

1.1 Veroista ja niiden luokitteluista............................... 13

1.2 Kulutusverot Ruotsin vallan aikana ......................... 14

1.2.1 Tulli ...................................................... 14

1.2.2 Alkoholivero........................................... 15

1.2.3 Tupakkavero ............................................ 16

1.2.4 Ylellisyys- ja huviverot ................................ 17

1.3 Kulutusverot Venäjän vallan aikana ......................... 18

1.3.1 Tulli ...................................................... 18

1.3.2 Alkoholivero............................................. 19

1.3.3 Tupakkavero ........................................... 20

1.3.4 Kunnallinen koiravero................................ 20

1.3.5 Pelikorttivero............................................. 22

1.3.7 Sota-ajan juna-, telefooni- ja huviverot ......... 23

1.4 Kulutusverot Suomen itsenäistymisestä 1990-luvun puoliväliin ....................................................... 24

1.4.1 Tulli ...................................................... 24

1.4.2 Alkoholivero .............................................. 25

1.4 .3 Tupakkavero ............................................. 25

1.4.4 Tulitikkuvero ............................................. 26

1.4.5 Makeis- ja virvoitusjuomaverot.................... 27

1.4.6 Kahvivero ............................................... 30

1.4.7 Sokerivero .............................................. 32 
Sisällys

1.4.8 Ravintorasvavero .................................. 33

1.4.9 Elintarvikkeiden valmistevero ................... 35

1.4.10 Rehuverot............................................ 37

1.4.11 Lannoiteverot ......................................... 39

1.4.12 Polttoainevero ........................................ 41

1.4.13 Polttoainemaksu.................................... 43

1.4.14 Sähkövero............................................. 45

1.4 .15 Kulta- ja hopeaverot ............................ 45

1.4.16 Koiravero............................................... 46

1.4.17 Huviverotus........................................... 47

1.4.18 Pelikorttivero....................................... 50

1.4.19 Vesiliikenteen väylämaksu ja raideliikenteen ratamaksu.......................................... 50

1.4.20 Ajoneuvovero .................................... 51

1.4.21 Autokumirengasvero............................... 53

1.4.22 Autovero ............................................. 54

1.4.23 Liikevaihtovero..................................... 62

1.4.24 Vakuutusmaksuvero .............................. 65

1.4.25 Meriliikenteen matkustajavero ................... 66

1.4.26 Ilmaliikenteen matkustaja- ja tilauslentoverot 67

1.4.27 Tietoliikenteen televero ............................ 69

1.5 Kulutusverot EU-jäsenyyden aikana...................... 69

1.5.1 Tulli .................................................... 69

1.5.2 Arvonlisäverotus .................................... 70

1.5.3 Alkoholi-, tupakka- ja energiaverot............. 70

1.5.4 Makeis-, jäätelö- ja virvoitusjuomavero........ 72

1.5 .5 Jätevero .............................................. 76

1.5.6 Autovero ............................................. 77

1.5.7 Ajoneuvovero ......................................... 79

1.5.8 Huviveneiden polttoainemaksu ................. 81

1.5.9 Väylämaksu ja ratavero ........................... 82

1.6 Yhteenveto kulutusverotuksen historiasta ............. 83 
2 VENEVERO HALLITUSOHJELMASSA 2015 JA VALTIOVARAINMINISTERIÖN ESITYSLUONNOKSESSA 2016

2.1 Tavoitteet ja toteuttamisvaihtoehdot.

2.2 Veron kohde ja rajaukset...................................... 87

2.3 Veron peruste ja määrä......................................... 88

2.4 Verotusmenettely.................................................. 89

2.5 Venerekisterilain muutokset................................... 91

2.6 Taloudelliset vaikutukset ........................................ 93

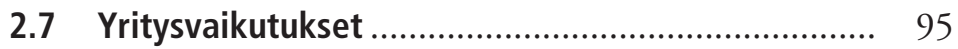

2.8 Ympäristövaikutukset .......................................... 95

2.9 Vaikutukset viranomaistoimintaan ......................... 96

2.10 Yhteiskunnalliset vaikutukset ................................. 97

2.11 Lakitekstiehdotus................................................ 98

3 VENEVEROSTA ANNETUT LAUSUNNOT ........................... 103

3.1 Pyydetyt ja pyytämättä annetut lausunnot.............. 103

3.2 Liikenne- ja viestintäministeriö.............................. 104

3.3 Oikeusministeriö ................................................. 104

3.4 Sisäministeriö, Poliisihallitus, Rajavartiolaitos ja Tulli ............................................................... 107

3.5 Ahvenanmaa ja Paraisten kaupunki........................ 109

3.6 Veronmaksajain Keskusliitto ry.............................. 111

3.7 Suomen Yrittäjät ry.............................................. 111

3.8 Venealan Keskusliitto Finnboat ry ......................... 112

3.8.1 Venealan vastuu julkisesta taloudesta............ 112

3.8.2 Fiskaalinen vaikutus .................................. 113

3.8.3 Veneily ja veneet Suomessa.......................... 113

3.8.4 Verokertymä veneilystä............................... 114

3.8.5 Veneilyn kehittyminen lähivuosina................ 116

3.8.6 Veneveron negatiiviset vaikutukset valtion kokonaisverotuloihin ................................. 116

3.8.7 Verotuottovakaus ja fiskaalinen joustavuus ... 117

3.8.8 Veneveron epäneutraalisuus ja haitalliset ohjausvaikutukset ...................................... 119

3.8.9 Oikeudenmukaisuusnäkökohtia .................. 120 
3.8.10 Venerekisterin puutteellisuudet ja epäluotettavuus

3.8.11 Verovelvollisen ilmoittamisvelvollisuus......... 124

3.8.12 Hallinnointikustannukset .......................... 124

3.8.13 Verovelvollisten yhdenvertaisuus ................. 125

3.8.14 Kansainväliset kokemukset ........................ 127

3.8.15 Lainvalmistelun laatu ja jatko ...................... 128

3.9 Suomen Purjehdus ja Veneily ry.............................. 129

3.10 Suomen Meripelastusseura ry, Ålands Sjöräddningssällskap ja palokunnat ...................... 135

3.11 Venepuuseppä...................................................... 138

3.12 Vesiskootteri- eli vesijettiyrittäjät.......................... 139

3.13 Venekerhot ......................................................... 142

3.14 Matkapurjehtijat .................................................... 144

3.15 Klassikkovene- ja höyrypursiseurat ........................ 146

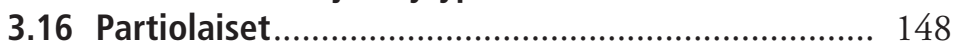

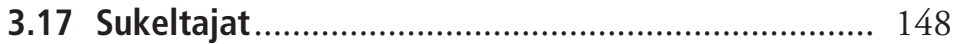

3.18 Kalastajat ja kalastusoppaat............................... 149

3.19 Saariston siisteyden edistäjät .............................. 152

3.20 Sähköajoneuvojen puolestapuhujat........................ 153

3.21 Auto- ja liikennetoimittajat ................................... 154

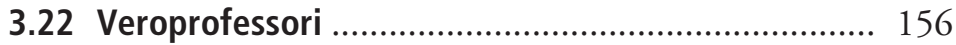

3.23 Yksittäiset kansalaiset .......................................... 157

4 TIIVISTELMÄ VENEVERON HAITOISTA JA EDUISTA ........ 161

4.1 Kielteistä ................................................................ 161

4.2 Myönteistä .............................................................. 163

5 VENEVERON HAUTAAMISESTA, ELVYTYKSESTÄ JA

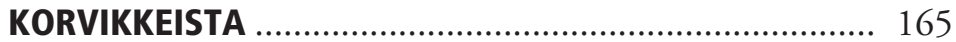

5.1 Esityksen torpedoiminen ja verotarve .................... 165

5.2 Haittaveroluonteinen venevero .............................. 166

5.3 Ulkomaanliikenteen matkustajaverot..................... 166

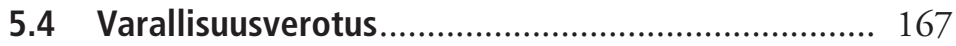

5.4.1 Varallisuusveron synty, kehitys, hiipuminen ja kuolema................................................... 167 
Sisällys

5.4.2 Varallisuuden verottamistavoista ja hyödykekohtaisesta varallisuusverosta ........... 169

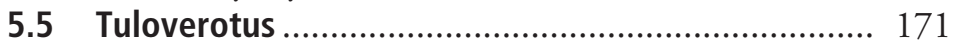

5.5.1 Tuloveron synty ja kehitys........................... 171

5.5.2 Osinkoverotuksen uudistaminen .................. 174

5.5.3 Työmarkkinajärjestöjen jäsenmaksujen vähennysoikeuden rajoittaminen ................. 176

5.6 Arvonlisäverokantojen korottaminen ..................... 178

5.7 Polttoaineveron korottaminen ja verotuksen ikuisuus .................................................................. 181

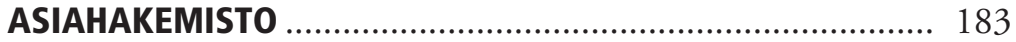




\section{1 \\ Kulutusverotuksen historia ${ }^{1}$}

\subsection{Veroista ja niiden luokitteluista}

Veroilla tarkoitetaan yleensä valtiolle ja muille julkisyhteisöille niiden tehtävien suorittamiseksi maksettavia vastikkeettomia suorituksia. Välittömän vastasuorituksen puuttuminen erottaa verot maksuista.

Veroissa voidaan erottaa kaksi pääryhmää. Ensimmäiseen ryhmään kuuluvat tuottoverot sekä tulovero, varallisuusverot ja omaisuuden siirtojen verot. Toinen ryhmä muodostuu varojen käytön eli kulutuksen veroista.

Vanhimpina aikoina verot perustuivat jopa valtaosin kiinteistön tai muun omaisuuden arvioituun tuottoon. Tästä ajasta muistona meillä on vielä kunnallinen kiinteistövero. Todelliseen tuloon perustuva yleinen tuloverotus on historiallisesti uusi ilmiö. Valtion tuloverotus tuli meille noin 150 vuotta sitten, ja yhtäjaksoisesti tuloveroa on kannettu Suomessa noin 100 vuotta. Yleinen varallisuusverotus on täydentänyt tuloverotusta, mutta se ei ole osoittautunut yhtä elinkelpoiseksi. Omaisuuden siirtoveroihin kuuluvat muun muassa varainsiirtoverotus ja perintöverotus, joiden merkitys on viime aikoina vähentynyt.

Tämän luvun tiedot perustuvat huomattavalta osalta teokseen Esko Linnakangas - Leila Juanto, Verojen historia - Synty, kehitys, kuolema, ylösnousemus, reinkarnaatio (2016) ja siellä mainittuihin lähteisiin. 
Kulutusveroja ovat monenlaisten tavaroiden tuonnista kannetut tullit ja erityiset kulutusverot. Erityisistä kulutusveroista, joita myös pisteveroiksi kutsutaan, tärkeimpiä ovat tietyistä tuotteista kannettavat valmisteverot. Tullit ja erityiset kulutusverot yhdessä ovat olleet Suomessa yleensä valtion tärkein verolähde. Niiden rinnalle ja tilalle on tullut yleinen kulutusverotus, joka alkoi liikevaihtoverotuksena ja kehittyi arvonlisäveroksi. Kulutusverot voivat kohdistua sekä tavaroihin että palveluihin.

Esimerkiksi tulovero, varallisuusvero ja perintövero luokitellaan välittömiksi veroiksi. Kulutusverot sen sijaan ovat tavallisesti välillisiä veroja, joissa verovelvollisen oletetaan vyöryttävän veron hyödykkeen hintaan sisältyvänä lopullisen kuluttajan rasitukseksi. Verojärjestelmässä voi olla myös välittömiä kulutusveroja. Sellainen on esimerkiksi koiravero. ${ }^{2}$ Myös ajoneuvovero luokitellaan lähinnä välittömäksi kulutusveroksi. Veron luokittelu välilliseksi tai välittömäksi on monesta syystä ongelmallista ja usein tarpeetontakin, minkä vuoksi tässä kirjassa ei sitä käytetä.

\subsection{Kulutusverot Ruotsin vallan aikana}

\subsubsection{Tulli}

Tullinkannon perimmäisin tarkoitus on ollut julkisen vallan tulojen lisääminen. Tullinkannon historia Ruotsissa ulottuu yhtä kauas kuin keskitetyn valtion historia; ensimmäinen kirjallinen todiste tullinkannosta on 1200-luvun puolivälistä. Silloin tehdyssä sopimuksessa taattiin lyypekkiläisille kauppiaille tullivapaus Ruotsissa ja ruotsalaisille kauppiaille Lyypekissä. Hansakauppiaiden laivat toivat suolaa, humalia, kankaita, viinejä ja mausteita. Paluumatkoilla ne veivät turkiksia, nahkoja, puutavaraa, rautaa, kuparia, voita ja kalaa.

2 Koiraveron luonteesta välillisenä/välittömänä verona on kiistelty 1900-luvun alun Saksassa, jossa tätä veroa on pidetty myös välillisenä verona. Suomessa sanotaan joskus, että kysymys on välillisestä verosta: veron maksajana ei ole koira. 
Rahaa tarvittiin etenkin sotalaitoksen menoihin. Vuonna 1536 määrättiin $5 \%$ :n arvotulli kaikista tuontitavaroista paitsi suolasta ja humalasta, joihin sovellettiin paljoustullia. Suolan ja humalan paljoustullit vastasivat vain 1,3-3,3 prosenttia tuontihinnasta. Aateliston ja papiston ei tarvinnut maksaa tullia tuontitavaroistaan. Tuontitavaroista tärkein oli suola, jonka osuus Turun kautta tapahtuvan tuonnin arvosta vaihteli 1500-luvun lopulla $50 \%$ :n molemmin puolin. Toiseksi tärkein ryhmä olivat kankaat.

Ruotsista alettiin tehdä suurvaltaa Kustaa II Aadolfin (1611-1632) hallituskaudella. Sotakoneiston käynnissä pitämiseen tarvittavien lisätulojen hankkimiseksi säädettiin myös uusi tulli, pikkutulli, vuonna 1622. Sitä ei kuitenkaan peritty ulkomaankaupasta, vaan sillä verotettiin kotimaankauppaa. Pikkutullia kannettiin kaikista "syötävistä, pidettävistä ja kulutettavista tavaroista", jotka tuotiin maaseudulta kaupunkiin.

\subsubsection{Alkoholivero}

Ensimmäinen myös Suomea koskenut paloviina-asetus viinan valmistuksen verottamisesta annettiin vuonna 1638. Viinanpoltto jaettiin kotitarvepolttoon ja myyntipolttoon, joista jälkimmäinen oli ankaramman verotuksen kohteena. Vero määräytyi käytettyjen raakaaineiden mukaan. Se ei kuitenkaan koskenut maaseutua, toisin kuin vuonna 1655 käyttöön otettu anniskeluvero. Paloviinan verotus päättyi vuonna 1698, kun viinanpoltto kiellettiin koko valtakunnassa, mutta 1700-luvulla viinanpoltto jälleen sallittiin. 1700-luvulla harjoitettu alkoholipolitiikka oli poukkoilevaa. Määräykset vaihtelivat täydellisen polttovapauden ja ehdottoman valmistuskiellon välillä, ja myös verosäännökset muuttuivat nopeaan tahtiin. Vuonna 1787 viinanpoltto julistettiin luvalliseksi maanomistajille ja kaupungeille, jotka joutuivat maksamaan tästä oikeudesta veroa, mutta vasta vuonna 1800 annetulla säädöksellä asia tuli laillisesti järjestetyksi.

Mallasjuomien verotus oli Ruotsi-Suomessa käytössä koko 1700-luvun, mutta mallasjuomien kulutus laski 1700-luvulla voimakkaasti, kun paloviinan kulutus syrjäytti sitä.

Alkoholijuomien verotusta perusteltiin jo 1700-luvulla paitsi valtiontaloudellisilla myös kulutuksen supistamista tavoittelevilla syillä. 


\subsubsection{Tupakkavero}

Tupakka tuli tunnetuksi Keski- ja Etelä-Euroopassa 1500-luvun alussa. Sitä viljeltiin aluksi lääkekasvina, mutta nautintoainekäyttö syrjäytti nopeasti lääketieteellisen käytön. Suomessa tupakka tuli tunnetuksi 1630-luvulla.

Ruotsi-Suomi oli melkein koko 1600-luvun eurooppalainen suurvalta, ja sen harjoittama sotilaallinen toiminta oli vilkasta. Suurvalta-aseman ylläpitäminen edellytti suuria taloudellisia voimavaroja, joiden lisäämisessä verotus oli yksi keino. Tupakka tuli Ruotsi-Suomessa verotuksen kohteeksi ensimmäisen kerran 1630-luvun lopulla. Pian tupakan maahantuontiin kuitenkin alettiin soveltaa monopolia. Monopolin avulla pyrittiin hankkimaan valtiolle lisätuloja, ja toisaalta tarkoituksena oli vähentää tupakan maahantuontia ja siten estää tupakan käytön laajenemista. Tupakkaa nimittäin paheksuttiin hyödyttömänä ylellisyystavarana. Monopolista luovuttiin vuonna 1649, jolloin siirryttiin takaisin vapaakauppaan ja tulliverotukseen, mutta monopoli oli tämän jälkeenkin käytössä vuosina 1654-1660 ja 16621685. Monopolijärjestelmän aikana ja sen jälkeenkin oli tupakanviljely valtakunnassa kielletty, koska pelättiin, että peltopinta-alasta yhä suurempi osa olisi uhrattu tupakkakasville leipäviljan kustannuksella.

Tupakkapolitiikka muuttui 1700-luvulla olennaisesti, sillä tuolloin alettiin tupakanviljelyä nimenomaisesti edistää. Muutoksen taustalla lienevät olleet kauppa- ja maksutasepolitiikkaan liittyvät syyt. Kun tupakkaa viljeltiin kotimaassa, sen maahantuontia pystyttiin vähentämään.

Tullin lisäksi tupakasta kannettiin vuodesta 1722 alkaen leimamaksua. Vuonna 1747 alettiin tupakan ja eräiden muiden ylellisyystavaroiden kulutuksesta kantaa erityistä veroa (aksiisia). Vuonna 1800 säädettiin tupakkasuostunta niille, jotka polttivat, nuuskasivat tai purivat tupakkaa. Veron suuruus määräytyi muun muassa säädyn ja varallisuuden mukaan. Sen maksamisesta olivat vapautettuja naiset sekä maa- ja merisotaväen miehistö. 


\subsubsection{Ylellisyys- ja huviverot}

Rooman keisarikunnan luhistuttua peruukit jäivät Länsi-Euroopassa tuhanneksi vuodeksi pois ja palasivat vasta 1500 -luvulla. Paluuseen vaikutti sekin, että peruukkia suosittiin hygieenisistä syistä. Taistelussa täitä vastaan oli hyödyllistä ajella hiukset pois ja käyttää ehkä helpommin puhdistettavaa peruukkia. 1700-luvulla yleistyivät erityisesti miesten valkopuuteroidut peruukit. Etenkin naisten peruukeista tuli 1700-luvulla hyvinkin suuria, ja monet näkivät peruukit yläluokan tuhlailuna. Peruukkien käyttöoikeudesta kannettiin valtiontaloudellisista syistä vuotuista veroa. Peruukkivero löysi ylellisyysverona tiensä jo vuonna 1710 myös Ruotsi-Suomeen.

Vuonna 1716 annetulla asetuksella Ruotsi-Suomeen säädettiin vero hienoille puvuille. Korkein maksu meni kulta- ja hopeavaatteista, kukallisista ja vastaavista silkkikankaista sekä ulkomaisesta sametista. Pönkkähame katsottiin osoitukseksi ylellisyyshimosta, ja ylellisyysasetus vuodelta 1731 oikeutti vain ylhäisimmät naiset käyttämään kyseistä vaatekappaletta. Kun käytännössä kävi vaikeaksi tehdä tarkkaa eroa ylhäisen ja alhaisen naisen välillä, niin määrättiin, että jokaisen naisen, joka tahtoi esiintyä tässä pukimessa, oli suoritettava valtiolle yhden taalerin vero.

Vuonna 1716 myös makeiset säädettiin eräänlaisen ylellisyysverotuksen kohteeksi. Samaan aikaan kahvin kulutuksesta alettiin kantaa ylellisyysveroa. Suomeen kahvi ei ollut kuitenkaan vielä tuolloin sanottavasti levinnyt. Vuonna 1747 säädetty vero kahvin kuluttajille sen sijaan vaikutti myös Suomessa. Sen suuruus riippui yhteiskuntaluokasta ja asuinpaikasta. Veroa ei tarvinnut maksaa, kun kahvin juonti tapahtui lääkärin määräyksestä. Merkantilismin hengen mukaisesti veron taustalla oli pyrkimys vähentää kahvin kulutusta ja sitä kautta tarvetta kahvin maahantuontiin. Vireillä oli myös hankkeita kotimaisten korvikkeiden käytön suosimiseksi.

Kahviverolla ei kuitenkaan onnistuttu vähentämään maahantuontia. Vuonna 1756 talonpoikaissäädyn voimakkaalla tuella säädettiinkin kahvin maahantuonnin ja käyttämisen kieltänyt laki. Talonpojat olivat kuohuksissaan, kun heiltä oli vähän aikaisemmin kielletty viinanpoltto-oikeus, ja he kostivat nyt ajamalla lävitse kahvikiellon. Kieltolaki kumottiin jo vuonna 1761, ja kahville säädettiin tuontivero. 
Kahvikysymys oli kuitenkin ongelmallinen koko 1700-luvun loppupuolen, ja kahvin kieltolakikin oli käytössä vielä useaan otteeseen.

Ylellisyysvero oli myös vaunuvero. Sellainen hyväksyttiin RuotsiSuomessa vuoden 1731 valtiopäivillä 6-50 taalerin suuruisena.

Huviveron juuret ulottuvat 1700-luvun lopulle. Erilaisten artistien (Comodianter och Marionettspelare, Lindansarne och dylika) oli nimittäin vuonna 1782 annetun julistuksen mukaan suoritettava jokaisesta esiintymiskerrasta maksu Kehruuhuonerahastoon. Kehruuhuone oli vanha nimitys naisten työvankiloille. Niissä vangeilla teetettiin lähinnä käsitöitä, kuten kehruuta. Naisten vankilaan joutumisen yleisin syy tuohon aikaan oli vastasyntyneen lapsen surmaaminen.

Vanha ylellisyysvero on palvelijavero. Se levisi 1700-luvun lopulla myös Ruotsi-Suomeen. Vuonna 1789 määrättiin maksettavaksi veroa tarpeettomista palvelijoista, kuten kamaripalvelijoista ynnä muista palvelijoista, joita pidettiin yli arvojärjestyksen perusteella määrätyn luvun; maksu oli 4-8 riikintaaleria. Kotipapin pitämisestä oli maksettava 12 riikintaaleria ja kokista 10 riikintaaleria.

Vuonna 1800 ylellisyysverojärjestelmäämme tuli koiravero. Se oli kaksi killinkiä metsästyskoirasta. Muista koirista vero oli yksi taaleri yhdestä koirasta ja seuraavista kaksi taaleria kustakin. Kahlekoirat ja paimenkoirat olivat verovapaita.

\subsection{Kulutusverot Venäjän vallan aikana}

\subsubsection{Tulli}

Venäläiset pyrkivät jo Suomen sodan aikana rauhoittamaan suomalaisten mielialoja, jotta maan saattaminen Venäjän keisarin alaisuuteen sujuisi joustavasti. Maaliskuussa 1808 lakkautettiin pikkutulli, jota oli kannettu kotimaankaupassa vuodesta 1622 . Porvoon valtiopäivillä maaliskuussa 1809 Aleksanteri I antoi hallitsijanvakuutuksensa ja lupasi pitää maan lait voimassa.

Keisarin Suomelle vahvistama ensimmäisen oma tullitaksa tuli voimaan kesäkuussa 1812. Se oli venäläisen taksan käännös ja hyvin 
erilainen kuin Ruotsin vallan aikaiset tullitaksat. Joidenkin ylellisyystavaroiden tuontitulli alentui. Joidenkin tavaroiden, muun muassa tupakan, tulli nousi.

Veroista tärkein oli Suomen autonomian ajan alussa maavero. Vuonna 1811 maaverojen tuotto tullituloihin verrattuna oli 20-kertainen. Tullitulojen osuus kasvoi 1840-luvulla merkittävästi ja oli 1800-luvun puolivälissä noin $40 \%$ kaikista veroista. Tulleista oli tullut valtiontalouden selkäranka, ja vuonna 1900 valtio sai noin $70 \%$ verotuloistaan tulleista. I maailmansodan aikana tullitulot putosivat niin, että vuonna 1917 ne olivat enää $15 \%$ valtion verotuloista.

\subsubsection{Alkoholivero}

Kun Suomi vuonna 1809 liitettiin Venäjään, paloviinan valmistus säilyi maanomistajien ja kaupunkien etuoikeutena. Vaikka paloviinalainsäädännön uudistamista pidettiin viinan kotitarvepolttoon liittyneiden suurten ongelmien vuoksi tarpeellisena, uudistusta ei voitu saada toteutetuksi ennen valtiopäivien koolle kutsumista 1860-luvulla. Viinan kotitarvepolton kieltäminen ja paloviinan valmistuksen myöntäminen tehdaspolttimoille säädettyä veroa vastaan olivatkin valtiopäiväasioista keskeisimpiä.

Uudistus tuli voimaan vuoden 1866 alusta. Paloviinaveron tuoton käytöstä oli oma asetus, ja vero liittyi Suomen rautatieverkoston laajentamiseen. Vuonna 1876 määrättiin suoritettavaksi myös paloviinan anniskelusta erityistä veroa.

Autonomian ajan ensimmäisinä vuosikymmeninä Suomessa ei ollut mallasjuomien verotusta. Mallasjuomien käytön lisäännyttyä ja noiden juomien tehdasmaisen valmistuksen alettua 1850-luvulla tuli mallasjuomien verottaminen uudelleen ajankohtaiseksi. Mallasjuomien verotus perustui aluksi tulosuostunnasta annettuihin säädöksiin. Vuoden 1883 alusta tuli voimaan asetus suostuntaverosta mallasjuomain valmistuksessa. Siinä säädettiin kotimaisen valmistajan maksettavaksi veroa oluen valmistukseen käytetyn mallasmäärän mukaan. Vero liittyi osaltaan samoihin aikoihin säädetyn tupakkasuostunnan kanssa asevelvollisuuden käyttöönotosta aiheutuneiden menojen kattamiseen. 


\subsubsection{Tupakkavero}

Autonomisessa Suomessa jatkettiin Ruotsin vallan ajalta peräisin ollutta tupakan verottamista tullin muodossa. Kotimaisen tupakanviljelyn ja tupakkateollisuuden asema oli autonomian alkuvuosikymmeninä heikko Venäjän protektionistisen tullipolitiikan vuoksi: Suomesta Venäjälle viedystä tupakasta oli suoritettava tullia, mutta Venäjältä Suomeen tuotu tupakka oli tullivapaata. Tilanne osittain helpottui, kun vuonna 1859 alettiin kantaa tullia venäläisistä tupakanlehdistä ja vuonna 1873 tupakanvarsista. Venäjältä Suomeen tuodut tupakkavalmisteet jäivät kuitenkin edelleen tullivapaiksi. Maahan tuodusta tupakasta kannettiin vuosina 1859-1892 merenkulkumaksun nimellä lisätullia.

Asevelvollisuuden käyttöönotto vuonna 1881 johti sotilasmenojen kasvamiseen, minkä vuoksi valtiolle tarvittiin lisätuloja. Asiaa selvittänyt komitea katsoi, että yksi mahdollinen keino valtion tulojen kasvattamiseksi oli lisätä tupakan verotusta kantamalla tupakasta tullin lisäksi suostuntaveromaksua. Aluksi suostuntaveromaksua säädettiin kannettavaksi vuoden 1885 loppuun, mutta myöhemmin maksun kantamista jatkettiin vuoden 1891 loppuun. Tupakkasuostuntamaksua kannettiin vain maahan tuodusta tupakasta; kotimainen tupakkatuotanto jäi verottomaksi. Vuoden 1891 valtiopäiville annettiin esitys, jossa tupakasta ehdotettiin kannettavaksi aksiisia, mutta esitys hylättiin. Tupakan verotus säilyi kuitenkin aikaisemmalla tasolla, kun tupakasta säädettiin kannettavaksi tuontimaksua sama määrä, joka aikaisemmin oli kannettu suostuntaveromaksuna.

\subsubsection{Kunnallinen koiravero}

Ensimmäinen kunnallinen koiraveromme säädettiin vuonna 1878. Se tapahtui erityisesti terveyspoliittisista syistä. Tavoitteena oli vesikauhun torjuminen kansalaisten ja kotieläinten suojelemiseksi. Vapaana kuljeksivat koirat edistivät vesikauhun leviämistä, ja vailla hoitoa ja ruokaa olevat koirat myös hävittivät metsänriistaa. Sen vuoksi säädettiin koiran omistajan maksettavaksi koiravero ja määrättiin poliisi tappamaan koirat, joista ei ollut veroa maksettu. Vero oli käytettävä 
ensisijaisesti korvauksiin vesikauhun vuoksi menetetyistä kotieläimistä; loput saatiin käyttää muihin kunnallisiin tarkoituksiin. Eduskunnassa viitattiin myös ylellisyysnäkökohtiin ja veronmaksukykyyn toteamalla:

"Useissa tapauksissa maksaa koira vuosittain omistajalleen joltisenkin summan, tekemättä hänelle vähintäkään hyötyä, tahi ainakaan niin suurta, että se vastaisi koiran elatusta, ja silloin on koirien pitäminen suorastaan ylellisyyttä, jota syystä voi veroittaa; muissa tapauksissa ovat ne tosin suuresti hyödyksi ja tarpeellisia, mutta silloin voi niistä myöskin kantaa kohtuullista veroa."

Koiraveron määräksi ehdotettiin "maalla, jos koiraa käytetään talonvartijana taikka karjan kaitsemiseen taikka metsästykseen, kaksi markkaa ja muista koirista kuusi markkaa, sekä kaupungissa tahi kauppalassa kaikenlaisista koirista niinikään kuusi markkaa”. Valiokunta kuitenkin vastusti veron säätämistä erisuuruiseksi eri koiralajeilta. Se totesi, että veron määrän säätämisestä koiralajista riippuvaksi olisi tullut "joutavia riitoja" ja vääriä ilmoituksia, koska moni koiranomistaja yrittäisi saada koiransa talonkoirain tahi paimenkoirain luokkaan lainkaan katsomatta siihen, oliko koira sellaiseen tarkoitukseen kelpaava. Veroksi säädettiin maalla kaksi markkaa sekä kaupungissa ja kauppalassa kuusi markkaa koiralta. Eroa maaseutukoirien ja kaupunkikoirien verotuksen välillä perusteltiin sillä, että kaupungeissa koiria vain poikkeustapauksissa pidettiin tarpeen vuoksi.

Koiravero vaikutti halutulla tavalla: koirat vähenivät, samoin vesikauhu. Vuonna 1882 annettiin esitys, jossa ehdotettiin, ettei koiraveroa toistaiseksi ollut perittävä maaseudulla olevista koirista. Viitattiin siihen, että maan lounaisosassa sudet olivat tappaneet useita lapsia. Uskottiin, että tätä voitiin estää käyttämällä yleisemmin koiria, joiden haukunta varoitti asujaimistoa lähestyviltä pedoilta. Koiraveron kannon lopettamiseen maaseudulla vaikutti sekin, ettei verolla ollut kansan kannatusta ainakaan sellaisilla seuduilla, joilla ei esiintynyt vesikauhua. Mainittu esitys hyväksyttiin, ja annettiin säädös, joka lopetti koiraverotuksen maalla.

Vesikauhu alkoi taas levitä 1880-luvun lopussa ja 1890-luvun alussa, mikä aiheutti vaatimuksia koiraveron palauttamiseksi myös maaseudulle. Koiria syytettiin siitäkin, että ne hävittivät linnunpoikia 
ja muuta hyödyllistä riistaa ja tappoivat jopa lampaita. Varattomien koiranpitoa arvosteltiin ankarasti:

"Koiria eivät pidä ainoastaan varakkaammat ja ne perheet, jotka itse kykenevät elatuksensa hankkimaan, vaan melkeinpä poikkeuksetta sellaisetkin perheet, joille vaivaishoito antaa elatuksenapua. Tällaiset koirain omistajat, joilla omakin ravinto on usein hyvinkin niukka ja puutteellinen, eivät tietysti voi elukoilleen antaa tarpeellista ravintoa, joten koirain pitäminen tässä tapauksessa on katsottava suoranaiseksi eläinräkkäykseksi.”

Vuoden 1894 lopulla säädettiin uusi asetus koiraveron suorittamisesta. Porolappalaiset sekä muut porokarjan omistajat vapautettiin maksamasta veroa paimenkoiristaan. Vero säädettiin kannettavaksi ja hoidettavaksi muiden kunnallisverojen yhteydessä ja käytettäväksi "kunnan mielen mukaan kunnan tarkoituksiin". Sitä ei siis enää kohdistettu ensi sijassa vesikauhun vuoksi menetettyjen kotieläinten korvaamiseen. Tässä viitattiin koiraveron vähäiseen tuottoon ja niihin vaikeuksiin, joita syntyi jaettaessa varoja korvausta vaativien kesken.

Koiraveron määrässä säilyi kuntamuotoon perustuva ero. Kunnan asiana oli säädetyissä rajoissa määrätä veron suuruus. Veron määräämistä erisuuruiseksi eri koiralajeille vastustettiin muun muassa viittaamalla sekarotuisten koirien määrään ja siihen, että erottelu oli maaseudulla tarpeeton, koska "korukoiria siellä on vähän".

\subsubsection{Pelikorttivero}

Pelikortit tulivat verotuksen kohteeksi Ruotsi-Suomessa ensimmäisen kerran 1700-luvulla, jolloin veroa kannettiin leimamaksun muodossa. Pelikorttiverotuksen historia autonomian aikana alkaa vuodesta 1842. Silloin säädettiin Suomessa valmistetuista pelikorteista suoritettavaksi leimamaksua. Pelikorttien maahantuonti Suomeen oli kielletty vuonna 1841, mutta maksu koski ulkomailta ennen tuontikiellon antamista tuotuja pelikortteja.

Vuonna 1865 pelikorttien valmistajat määrättiin maksamaan tulosuostunnan ohella ylimääräistä suostuntaveroa jokaisesta myydystä korttipakasta. Tämä pelikorttisuostunta voidaan ainakin osittain rinnastaa valmisteveroihin, sillä vero määräytyi myytyjen tuotteiden 
määrän eikä tuotteista saadun tulon perusteella. Vuonna 1882 pelikorteista kannettavasta suostuntaverosta annettiin erillinen säädös, ja siten tämä vero eriytettiin tulosuostunnasta.

Pelikorttiveron luonnetta valtiovarainvaliokunnassa 13.9.1907 pohdittaessa edustaja Huoponen (nuorsuom.) lausui muun muassa:

"Suostuntaveroja [--] tarvitaan ja sillä perustellaan tätä korottamista, mutta ei mainita sanaakaan toisesta minun mielestäni paljoa tärkeämmästä, siveellisestä puolesta. [--] jotenkin laajalla alueella Suomessa varsinkin Karjalassa kortinpeluu on muuttunut aivan kansallispaheeksi, jonka sekä siveelliset että kansantaloudelliset seuraukset ovat äärettömät [--].”

Samassa tilaisuudessa edustaja $V$. Vuolijoki (sd.) piti pelikorttiveroa jonkinlaisena varallisuusverona, sillä "ne, jotka sen veron maksavat, ovat pääasiallisesti herraspelureita, jotka ostavat kapakassa kortit; köyhempi kansa, niinkuin tukkimiespelurit, ostavat käytettyjä kortteja”.

Vuoden 1914 valtiopäiville ei annettu esitystä pelikorttisuostunnan kantamisesta vuonna 1915, eikä pelikorttisuostunta sisältynyt myöskään leimasuostuntaa koskeneeseen esitykseen. Koska pelikorteista peritty leimamaksu korotettiin hallinnollisella asetuksella, pysyi pelikorttien verotus kuitenkin entisen suuruisena. Eduskunta katsoi, että oikeutta tällaisen asetuksen antamiseen ei olisi ollut, koska pelikorttimaksu ei ollut luonteeltaan maksu vaan vero, jonka korottamiseen hallitsijalla ei olisi ollut oikeutta ilman eduskunnan suostumusta. Pelikorttileimamaksun kantamista jatkettiin hallinnollisen asetuksen nojalla vuoden 1915 jälkeenkin.

\subsubsection{Sota-ajan juna-, telefooni- ja huviverot}

Ensimmäisen maailmansodan aiheuttamien rahoitusongelmien hoitamiseksi otettiin Suomessa ilman eduskunnan myötävaikutusta käyttöön ylimääräisiä veroja, niin sanottuja sotaveroja. Vuonna 1914 annettiin muun muassa asetus rautateiden matkustajilta kannettavasta väliaikaisesta verosta, joka oli $25 \%$ lipun hinnasta. Sotaveroihin kuului myös telefoonivero, josta annettiin asetus vuoden 1915 alussa.

Keisarin armollisessa asetuksessa julkisista näytännöistä ja huvitilaisuuksista kannettavasta väliaikaisesta verosta joulukuussa 1914 mää- 
rättiin pääsymaksuista kannettavaksi sodan aikana erityinen valtiolle menevä vero. Vero säädettiin sotaverona ilman eduskuntamme myötävaikutusta. Huvivero ymmärrettiin aluksi lähinnä ylellisyysveroksi.

Huviverosta olivat vapaita ne tilaisuudet, joiden puhdas tuotto meni kokonaan sellaisille yhdistyksille ja laitoksille, joiden tarkoituksena oli haavoittuneiden ja sairaiden sotilaiden hoitaminen tai huolenpito sotaan kutsuttujen perheistä. Vero oli aluksi $10 \%$ pääsylipun hinnasta, mutta se korotettiin $20 \%$ :ksi vuonna 1916. Vero kannettiin siten, että pääsylippuun kiinnitettiin veron määrää vastaavat postimerkit. Merkit oli kiinnitettävä lippuihin siten, että merkkien yläosa jäi kävijälle annettavaan pääsylippuun ja alaosa lippuvihon kannassa olevaan lipun osaan.

\subsection{Kulutusverot Suomen itsenäistymisestä 1990-luvun puoliväliin}

\subsubsection{Tulli}

Kun ulkomaankauppa oli ensimmäisen maailmansodan jälkeen päässyt taas vauhtiin ja kun tullimaksuja oli korotettu 1920-luvun alkupuolella, tullien osuus valtion verotuloista kohosi 55-60\%:n tasolle. Siellä se pysyi 1930-luvun loppupuolelle saakka.

Toinen maailmansota mullisti jälleen Suomen talouden sekä tullija muun verotuksen. Monivuotinen sodankäynti kasvatti valtiontalouden ennätykselliseksi. Suomen valtion menot olivat 1940-luvun alkuvuosina lähes kolminkertaiset vuoden 1938 menoihin verrattuna. Suurimman osan (57-70 \%) valtion menoista veivät puolustusmenot.

Tullitulot romahtivat sodan aikana, vaikka monien tavaroiden tuontitulleja korotettiin inflaationkin vuoksi voimakkaasti vuoden 1938 taksaan verrattuna. Kun tullien osuus valtion verotuloista oli vuonna 1938 vielä noin puolet, vuonna 1945 se oli pudonnut alle $2 \%:$ iin. Sodan jälkeen tullin osuus valtion verotuloista nousi jälleen niin, että vuonna 1955 se oli noin $20 \%$. Suomi teki vuonna 1961 sopimuksen EFTAn kanssa ja alensi tuontitullejaan. 1960-luvun 
lopulla tuontitullit poistuivat EFTA-alueelta ja Neuvostoliitosta tuoduista tavaroista. Tullitulojen määrä laski voimakkaasti ja oli vuonna 1965 enää noin 10 \% valtion verotuloista. Suomen sopimus EEC:n kanssa tehtiin vuonna 1974. Sen mukaisesti tullit Suomen ja EEC:n välisessä kaupassa poistuivat asteittain. Tullituotot vähenivät entisestään, fiskaalisesti lähes merkityksettömiksi.

\subsubsection{Alkoholivero}

Raittiusliike voimistui 1800-luvun lopulla. Eduskunta hyväksyi kieltolain ensimmäisen kerran vuonna 1907. Kieltolaki kuitenkin raukesi, kun siihen ei ennen voimaantulopäivää saatu keisarin vahvistusta senaatin kieltäydyttyä esittelemästä asiaa. Myös seuraava kieltolain säätämistä koskenut eduskunnan päätös vuonna 1909 jäi toteutumatta valtiollisten olojen kiristyttyä. I maailmansodan puhjettua vuonna 1914 muodostui paljolti kieltolakia muistuttava tila, kun senaatti sotatilan vuoksi kielsi kaiken väkijuomain jakelun lukuun ottamatta anniskelua tietyissä ravintoloissa.

Pian maamme itsenäistymisen jälkeen vuonna 1919 tuli voimaan kieltolaki, joka johti myös alkoholin valmisteverotuksen päättymiseen. Kieltolaille asetetut tavoitteet eivät toteutuneet, vaan salakuljetus ja muu rikollisuus lisääntyivät. Kun vielä laman syveneminen 1930-luvun alussa johti siihen, että valtiolle tarvittiin uusia verolähteitä, oli kieltolain kohtalo sinetöity. Laki kumottiin, ja alkoholijuomien verotus otettiin uudelleen käyttöön vuonna 1932.

\subsubsection{Tupakkavero}

Tupakkavalmisteveron käyttöönotosta annettiin eduskunnalle esitys marraskuussa 1918. Taustalla olivat Suomen itsenäistyminen ja sisällissotaan liittyneet valtiontaloudelliset syyt. Tupakan verotuksen lisäämistä pidettiin mahdollisena, koska ainoa tupakasta tuolloin kannettu vero, tulli, oli tupakan hintaan nähden alhainen.

Esityksessä todettiin, että tupakka oli erittäin sovelias verotuksen kohde. Veron käyttöönottoon liittyi myös ylellisyysveroajattelua. Tupakkaa pidettiin nautintoaineena ja sopivana verokohteena, koska 
se kuului niihin kulutushyödykkeisiin, jotka eivät olleet ihmiselle välttämättömiä. Tupakan valmisteverotus katsottiin tarkoituksenmukaiseksi toteuttaa arvoverotuksena. Tupakkatuotteet jaettiin veron määräämistä varten luokkiin vähittäismyyntihinnan mukaan.

Sota aiheutti 1930- ja 1940-lukujen vaihteessa sen, ettei tupakkatuotteita voitu valmistaa kysyntää vastaavaa määrää. Verotuksen kiristämisellä pyrittiin paitsi supistamaan tupakan kulutusta myös hankkimaan valtiolle lisätuloja, jotka olivat tarpeen vaikeassa taloudellisessa tilanteessa. Valtioneuvostolle annettiin oikeus myöntää veronhuojennus tupakkavalmisteille, jotka päämajan intendenttiosasto sotatilan aikana osti ja jakoi tai sotatoimialueella myi maanpuolustusjoukoissa palveleville. Huojennus koski myös sotasairaaloiden potilaille myytäviä tupakkavalmisteita. Suomessa pyrittiin myös verotuksellisin keinoin edistämään kotimaista tupakanviljelyä ja kotimaisen raakatupakan saamista teollisuuden käyttöön.

Sodan jälkeisenä aikana tupakan valmisteverotuksen perusteet säilyivät pääosin ennallaan. Suomen solmiman vapaakauppasopimuksen seurauksiin liittyi se, että kotimaisten ja ulkomaisten tuotteiden erilainen verokohtelu poistui vuonna 1964.

Vuonna 1979 säädetty uusi tupakkaverolaki oli merkittävä siksi, että sen säätämisen yhteydessä tuotiin nimenomaisesti esille veron terveyspoliittiset tavoitteet. Jo tätä ennenkin tupakan verotuksella oli pyritty vähentämään tupakan kulutusta terveyspoliittisten syiden vuoksi.

\subsubsection{Tulitikkuvero}

Tulitikkuveron käyttöönottoa suunniteltiin Suomessa jo autonomian aikana, ja sitä koskeva esitys annettiin vuoden 1891 valtiopäiville. Tulitikut olivat tuolloin aksiisiverotuksen kohteena Venäjällä. Säädyt kuitenkin hylkäsivät ehdotuksen, eikä hanke toteutunut. Hylkäämistä perusteltiin muun muassa sillä, että vero olisi rasittanut eniten taloudellisesti heikoimmassa asemassa olevia kansalaisia, koska se kohdistui välttämättömään kulutushyödykkeeseen. Veron katsottiin myös vaikuttavan haitallisesti suomalaiseen tulitikkuteollisuuteen.

Tulitikkuveroa alettiin Suomessa kantaa vuonna 1922. Sen säätämistä perusteltiin valtiontaloudellisilla syillä. Tulitikkuja pidettiin 
sopivana verotuksen kohteena muun muassa siksi, että tikkuja käytettiin usein tupakoinnin yhteydessä, jolloin vero muodostui tupakoitsijoihin kohdistuvaksi ylellisyysveroksi. Tupakkaliitynnän vuoksi silloinen tulitikkuvero voitaneenkin jälkiviisaasti luokitella tupakkaveron tapaan myös terveysveroksi.

Tulitikkuveron säätäminen ei tapahtunut eduskunnassa ongelmitta. Valtiovarainvaliokunnan mietintöön liittyneessä vastalauseessa ehdotettiin lain hylkäämistä ja tulitikkuteollisuuden saattamista valtion monopoliksi. Lakia ei saatu säädetyksi pysyväksi, vaan veroa kannettiin yksivuotisten lakien perusteella vuosina 1922-1937. Tulitikkuveron kantamisen jatkaminen vuodeksi 1938 oli vireillä eduskunta-aloitteen pohjalta. Hallitus teki tämän aloitteen hyväksymisestä luottamuskysymyksen, ja vero jäi silloin säätämättä.

Tulitikkuveroa alettiin kantaa uudelleen vuonna 1940, mikä liittyi sodan vuoksi kasvaneeseen varaintarpeeseen. Veron tuotto vuonna 1940 oli 1,4 \% valtion kaikista verotuloista, mutta vuonna 1947 se oli enää $0,4 \%$. Tulitikkuveroa kannettiin yksivuotisilla laeilla vuoden 1964 loppuun asti, jolloin tämä vero siirrettiin verohistorian vitriiniin.

\subsubsection{Makeis- ja virvoitusjuomaverot}

Vuonna 1925 Suomessa säädettiin makeisverolaki, ja se tuli voimaan vuonna 1926. Veron käyttöönottoa perusteltiin erityisesti valtiontaloudellisilla syillä. Makeisia pidettiin sopivana verokohteena sen vuoksi, että niitä voitiin yleensä pitää ylellisyystavaroina.

Hallituksen esityksessä todettiin, että makeisiin ei tavallisesti kohdistunut valmiille tuotteille asetettua tullia. Suomessa kulutetut makeiset oli nimittäin valmistettu pääasiallisesti kotimaassa. Hallituksen mukaan makeisia ei voitu verottaa riittävästi raaka-ainetullilla, koska tärkein makeisiin käytetty raaka-aine oli sokeri, jolle ravintoaineena ei voitu asettaa korkeaa tullia.

Verollisia tuotteita olivat karamellit, konfektit, pastillit, marmeladi kappaleiksi muodostettuna, marsipaani ja marsipaanivalmisteet, suklaa, ei kuitenkaan keittosuklaa, ynnä muut pääasiallisesti sokerista, suklaasta, kaakaosta, hedelmistä, manteleista, pähkinöistä tai hedelmänsydämistä valmistetut makeiset. Hallitus oli ehdottanut veron 
ulottamista koskemaan myös keksejä, keittosuklaata, kaakaojauhoa ja muita kaakaovalmisteita sekä lakritsia ja lakritsivalmisteita. $\mathrm{Ne}$ jätettiin kuitenkin veron ulkopuolelle, koska valtiovarainvaliokunnan mielestä niitä ei voinut pitää ylellisyystavaroina. Valiokunta perusteli lakritsivalmisteiden verottomuutta silläkin, että niitä käytettiin myös lääkinnällisiin tarkoituksiin.

Oppositiopuolue SDP:n vastalauseessa ehdotettiin koko lakiehdotuksen hylkäämistä, koska makeisvalmisteveron säätäminen lisäsi välittömien verojen ja kulutusverojen välistä epäsuhdetta ja koska vero jäisi huomattavalta osin vähempivaraisten maksettavaksi. Myös oppositiossa olleen työväenpuolueen vastalauseessa ehdotettiin lain hylkäämistä. Siinä todettiin, että säätämällä valmisteveroja kulutustavaroille asetettiin vähäväkisten kansanluokkain maksettavaksi suhteellisesti paljon ankarampi verotus kuin varakkaille, samalla kun vähennettiin vähäväkisten tavaransaantimahdollisuuksia; ylellisyysveroja olisi asetettava sellaisille tavaroille, joita kuluttivat ainoastaan omistavat luokat.

Virvoitusjuomien kulutus alkoi kasvaa 1930-luvulla. Niiden valmisteverotuksen aloittakinen Suomessa ajoittui sotavuosiin; laki virvoitusjuomaverosta tuli voimaan vuonna 1940 . Veron käyttöönoton taustalla oli valtion vaikea taloudellinen tilanne. Virvoitusjuomia pidettiin sopivana verotuskohteena niiden ylellisyysluonteen vuoksi, ja virvoitusjuomat rinnastettiin tässä makeisvalmisteisiin. Veroa perusteltiin myös sillä, että virvoitusjuomista kannettiin veroa useissa muissakin maissa. Säätämällä keinotekoiset virvoitusjuomat valmisteveron alaisiksi pyrittiin myös vähentämään näiden juomien kulutusta ja edistämään kotimaisten hedelmien ja marjojen käyttöä virvoitusjuomateollisuuden raaka-aineena. Verosta vapautettiinkin kotimaisista marjoista, hedelmistä ja kasviksista valmistetut juomatuotteet. Verottomaksi säädettiin myös talouskalja, jonka raaka-aine oli kotimaista ja jonka todettiin olevan yleinen ruokajuoma köyhimmän väestön keskuudessa. Veroa ei kannettu myöskään Suomessa maidosta, piimästä tai herasta valmistetuista virvoitusjuomista.

Virvoitusjuomaverollisia tuotteita olivat ansiotarkoituksessa valmistetut "limonaadit ynnä hiilihapolla impregnoidut virvoitusjuomat kuten niin sanotut hedelmäjuomat, sitruunasooda, vichy- ja soodavesi ynnä muut keinotekoiset tai luontaiset kivennäisvedet, joita vir- 
voitusjuomina käytetään". Veronalaisia olivat myös "sima sekä muut pääasiallisesti vedestä, makeuttamisaineista, kasviuutteista, aromeista tai mausteista tehdyt juomat, joita pidetään kaupan pulloissa tai sifonia käyttäen tahi myyntipaikalla laseihin sekoittaen". Samoin veronalaisia olivat "edellä mainittujen juomien tarjoilupaikalla tapahtuvaa valmistusta varten tehdyt puolivalmisteet, kuten siirapit, väkimehut, ekstraktit, jauheet, pastillit ja muut kuivapakkaukset”.

Makeisten valmisteverotus perustui määräaikaisina voimassa olleisiin lakeihin. Makeisveron säätäminen pysyväksi tuli ajankohtaiseksi vuonna 1953, jolloin katsottiin, että makeisveron tuotto oli muodostunut niin merkittäväksi, ettei siitä voitu ainakaan silloisissa oloissa enää luopua. Uusi laki makeisvalmisteverosta tuli voimaan vuonna 1954, jolloin veron määrämisen perusteet osittain muuttuivat. Makeisverolaki korvattiin vuonna 1960 uudella lailla. Merkittävimpänä muutoksena oli se, että verotuksessa siirryttiin arvoverotuksesta yksikköverotukseen. Veromäärät säädettiin kuitenkin sellaisiksi, että veron kokonaistuotto pysyi ennallaan. Vero oli erisuuruinen suklaaryhmässä, karamelliryhmässä ja lakritsiryhmässä.

Vuoden 1940 virvoitusjuomaverolaki oli muuttamattomana voimassa 1950-luvun lopulle. Tällöin todettiin, että vaikka kaikkia virvoitusjuomia ei voitukaan enää pitää ylellisyyshyödykkeinä, ei valmisteverotuksesta valtion talouden tila huomioon ottaen voitu luopua. Vanhan virvoitusjuomaverolain suurimpana ongelmana pidettiin arvoverojärjestelmää. Uudessa laissa arvoverojärjestelmä korvattiinkin yksikköverojärjestelmällä.

Sekä makeisten että virvoitusjuomien valmisteverotuksen tavoitteet olivat 1960-luvulle saakka lähinnä fiskaalisia. Vapaakauppasopimusten seurauksena nousivat esille myös ulkomaankauppapoliittiset ja kotimaisen tuotannon suojelemiseen liittyvät tavoitteet.

Merkittävin 1970-luvulla virvoitusjuomien valmisteverotusta koskenut muutos oli vuoden 1976 alusta käyttöön otettu kertakäyttöpäällyksiin pakattujen virvoitusjuomien lisävero. Lisäveron tarkoituksena oli ympäristönsuojelulliset näkökohdat huomioon ottaen ehkäistä virvoitusjuoma- ja panimoteollisuuden siirtyminen yhä lisääntyvään kertakäyttöpäällyksien käyttöön.

Keskustelun terveyspoliittisista tavoitteista makeisverotuksen yhteydessä voidaan ainakin lainvalmisteluasiakirjojen perusteella 
katsoa alkaneen varsinaisesti 1970-luvulla. Esimerkiksi hyväksyessään vuonna 1976 lain makeisveron väliaikaisesta muuttamisesta eduskunta edellytti hallituksen ryhtyvän kiireellisesti toimenpiteisiin, joilla makeisvero voitaisiin kohdistaa tarkoituksenmukaisesti eri tuotteisiin siten, että kansanterveydellisesti suositeltavimmat makeisvalmisteet, kuten koivusokerituotteet, olisivat lievemmän verotuksen kohteena kuin muut makeisvalmisteet. Koivusokeria sisältävien makeisten (ksylitolimakeisten) lievempi verotus saatiin kuitenkin toteutetuksi vasta 1990-luvun puolivälissä.

Ruotsissa toteutettiin vuonna 1993 uudistus, jossa luovuttiin sellaisista valtiontaloudelliselta merkitykseltään vähäisistä veroista, jotka eivät olleet välttämättömiä yhteiskunnallisen ohjauksen välineenä. Näin makeisvero ja virvoitusjuomavero siirtyivät siellä historiaan. Makeisverosta luopumista perusteltiin myös kilpailuneutraaliussyillä. Verotuksen ulkopuolella oli sellaisia tuotteita, jotka rinnastuivat kuluttajien mielestä verollisiin tuotteisiin. Hyvänä ratkaisuna ei pidetty tällöin sitä, että verotuskohteiden piiriä olisi laajennettu, koska silloin olisi muodostunut uusia, vaikeita verollisten tuotteiden määrittelyongelmia. Myös virvoitusjuomaverosta luopumista perusteltiin Ruotsissa kilpailuneutraaliussyillä ja kohteen rajausongelmilla.

\subsubsection{Kahvivero}

Autonomian aikana kahvista ei kannettu Suomessa muuta veroa kuin tullia. Vaikka kahvin tulli oli korkea, piti ylellisyysveroja tutkinut $\mathrm{Ilm}$. Kovero 1930-luvun alussa mahdollisena kahvin verotuksen korottamista. Pahimmaksi veron uhaksi mainittiin salakuljetusvaara.

Erityisen kahviveron käyttöönotto Suomen itsenäisyyden aikana ajoittuu II maailmansodan aiheuttamiin poikkeuksellisiin oloihin. Kahvi oli sokerin ohella ensimmäisiä tuotteita, joita ryhdyttiin tuolloin säännöstelemään. Säännöstelyn aloittamista pidettiin kiireellisenä asiana, koska maahantuonti kulutti niukkoja valuuttavaroja. Säännöstely toteutuikin 28.10.1939, jolloin kansanhuoltoministeriö sai oikeuden vahvistaa kahvin ylimmät myyntihinnat.

Kahvin kulutusta ei kuitenkaan katsottu tarpeelliseksi saattaa kokonaan säännöstelyn piiriin, vaan katsottiin olevan syytä rajoite- 
tussa määrin sallia ostaa kahvia myös vapaassa kaupassa. Koska tällaisen vapaaseen kauppaan jätetyn kahvin käyttöä säännöstelyn aikana pidettiin ylellisyysluonteisena, katsottiin perustelluksi kantaa siitä veroa valtion vaikean taloudellisen tilanteen helpottamiseksi. Vapaassa kaupassa ollutta kahvia kutsuttiin verokahviksi erotuksena säännöstelyn piiriin kuuluneesta korttikahvista.

Laki kahvista suoritettavasta verosta hyväksyttiin eduskunnassa yksimielisesti. Eduskunta edellytti, että säännöstelyn ulkopuolella oleva verokahvi oli pidettävä rajoituksitta tai sen kulutusta mahdollisimman vähän rajoittaen vapaassa kaupassa. Kansanhuoltoministeriön tarkoituksena oli ollut, että ainakin ensin verokahvia olisi myyty vain ravintoloille, juhliin ja edustustarkoituksiin.

Kahviveroa kannettiin paahdetusta kahvista 40 markkaa kilolta, ja veroa oli velvollinen suorittamaan asianomainen paahtimo. Verokahvia saivat pakata vain ne paahtimot, joille kansanhuoltoministeriö oli antanut siihen luvan. Valvonnan helpottamiseksi ainoastaan Suomessa toimivat paahtimot saivat valmistaa ja laskea kauppaan verokahvia. Verokahvi tuli aluksi kaupassa maksamaan noin 90-110 markkaa kilolta.

Laki kahviverosta oli aluksi voimassa vuoden 1940 loppuun. Vuonna 1940 kahvivero tuotti 1,5 \% valtion kaikista verotuloista. Kahviverolain voimassaoloa jatkettiin vielä vuosiksi 1941 ja 1942. Tämä osoittautui kuitenkin fiskaaliselta kannalta turhaksi, sillä kahvin saatavuuden heikkenemisen vuoksi kahvia ei laskettu enää vapaaseen kauppaan, minkä vuoksi veron tuotto oli vuonna 1941 minimaalinen ja vuonna 1942 veroa ei kertynyt enää lainkaan.

Vuoden 1941 jälkeen seuraava kahvierä saatiin Suomeen vasta 1940-luvun puolivälissä. Kahvivero otettiin uudelleen käyttöön vuonna 1948, kun kahvia oli jälleen paremmin saatavilla. Vero säädettiin, kun valtion tulo- ja menoarvion käsittelyn yhteydessä katsottiin, ettei tulo- ja menoarviota ollut mahdollista saada tasapainoon ilman valtion tulojen huomattavaa lisäämistä. Kahviveroa kannettiin paahdetusta kahvista 800 markkaa kilolta, jolloin kahvin kilohinnaksi laskettiin muodostuvan 2000 markkaa.

Kun valtion taloudellinen tilanne vaati kahviveron säilyttämistä vuoden 1948 jälkeenkin, hallitus ehdotti lain pysyväksi säätämistä. Tämä ei kuitenkaan toteutunut, vaan kahviveroa jatkettiin yksivuo- 
tisten lakien nojalla. Veromääriä muutettiin useasti. Suurimmillaan kahviveron tuotto oli vuonna 1949, jolloin se oli 2,02\% valtion kaikista verotuloista.

Joulukuussa 1949 annetulla valtioneuvoston päätöksellä vahvistettiin ensimmäisen kerran ylin vähittäismyyntihinta myös verokahville. Kahviveroa oli alun perin tarkoitus kantaa vapaaseen kauppaan jätetystä kahvista. Syyskuussa 1950 annetulla päätöksellä verokahvin vapaa myynti kuitenkin väliaikaisesti lopetettiin ja myös verokahvia alettiin jakaa korttia vastaan.

Vuonna 1951 kahviverolakia muutettiin siten, että veroa alettiin kantaa myös paahdetusta ja paahtamattomasta kahvista, joka tuotiin maahan muussa tarkoituksessa kuin säännösteltyyn kulutukseen.

Kahvin säännöstely päättyi maaliskuussa 1954, jolloin kumottiin myös kahviverolaki. Senkin jälkeen kahvista on kannettu tullia ja liikevaihtoveroa.

\subsubsection{Sokerivero}

Vuonna 1939 säädetyn sokeriveron säätämisen taustalla olivat sodan aiheuttamat poikkeukselliset olot ja valtion lisääntynyt varaintarve. Kotimainen raakasokerin tuotanto, jota valtio oli aikaisemmin joutunut tukemaan, kävi maailmansodan vuoksi tapahtuneen sokerin yleisen hinnannousun ja sokerin suojatullin korotuksen takia vuoden 1939 lopulla poikkeuksellisen edulliseksi. Tässä tilanteessa pidettiin kohtuullisena, että kotimainen sokeriteollisuus joutui osallistumaan valtion rahantarpeen tyydyttämiseen. Säädetty valmistevero ei siis kohdistunut maahan tuotuun sokeriin, vaan veroa kannettiin vain Suomessa sokerijuurikkaasta valmistetusta raaka- eli kidesokerista. Laki sokerista suoritettavasta verosta oli aluksi voimassa vuoden 1940 loppuun, mutta lain voimassaoloa jatkettiin vuodeksi kerrallaan kesäkuun 1949 loppuun saakka.

Sokeriveroa alettiin kantaa Suomessa seuraavan kerran vuonna 1975, jolloin tuli voimaan laki sokerijuurikkaasta valmistettujen tuotteiden valmisteverosta. Tämän sokeriveron pääasiallinen tavoite ei ollut valtiontaloudellinen, vaan vero liittyi kotimaisen sokerintuotannon edistämiseen eli Suomen maatalouspolitiikkaan. Veron tuotolla katettiin kotimaisen sokerintuotannon tuen tarvetta. 
Vuonna 1980 voimaan tullut sokeriverolaki liittyi valmisteverolainsäädännön kokonaisuudistukseen. Sokerin valmisteverojärjestelmä säilyi pääosin entisessä muodossaan. Laki säädettiin aluksi olemaan voimassa vuoden 1983 loppuun, mutta voimassaoloaikaa jatkettiin ensin vuoden 1988 loppuun, sitten vuoden 1991 loppuun ja viimein vuoden 1994 loppuun.

Maatalouspoliittisten valmisteverojen kantamisen lähtökohdat muuttuivat olennaisesti EU-jäsenyyden myötä, ja vuoden 1995 alusta sokeriverolaki kumottiin. Hallitus totesi, että Suomeen tuodaan paljon sokeria raaka-aineena sisältäviä tuotteita tai luonteeltaan niitä korvaavia tuotteita. Tällöin myös ne olisi tullut ottaa yhdenmukaisesti verotuksen piiriin. Vastaavasti kaikkien tuolloin verollisten tuotteiden vienti olisi ollut vapautettava verosta. Koska tuojia ja viejiä olisi ollut määrällisesti paljon, olisi verotuksen toimittaminen rajavalvonnan puuttuessa ollut vaikeaa. Tämä olisi johtanut siihen, että kotimainen teollisuus olisi joutunut huonompaan asemaan.

\subsubsection{Ravintorasvavero}

Kun pohditaan, pitäisikö kansanterveydellisistä syistä säätää rasvavero, on hyvä muistaa, että ravintorasvan valmistevero ei ole uusi keksintö, vaan sellainen vero oli meillä käytössä EU-jäsenyyteen asti.

Ravintorasvojen valmistevero, jolla säänneltiin lähinnä voin ja margariinin hintasuhdetta, kuului maatalouspoliittisiin valmisteveroihin. Huhtikuussa 1959 tuli voimaan laki eräistä ravintorasvoista suoritettavasta valmisteverosta, jonka perusteella kannettiin veroa margariinista ja eräistä muista siihen rinnastettavista ravintorasvoista. Margariinin hintakysymys oli ennen tämän lain säätämistä järjestetty osittain tullin ja osittain hinnantasauslain perusteella kannetun hinnantasausmaksun avulla. Kun margariinin tulli oli noussut vuoden 1958 alusta ja kun hallitus suunnitteli, ettei hinnantasauslain voimassaoloa jatkettaisi enää vuodeksi 1959, jouduttiin hintakysymys hoitamaan uudella tavalla. Hinnantasausmaksu korvattiin ravintorasvoista kannettavalla valmisteverolla.

Voirasvaa tuotettiin Suomessa tuolloin runsaasti, ja voin vienti ulkomaille oli noussut suureksi. Kun vientihinta oli alhainen, vienti 
oli taloudellisesti epäedullista. Tämän vuoksi pidettiin välttämättömänä, että voin kotimainen kulutus olisi riittävän suuri.

Ravintorasvojen valmisteverotuksesta luovuttiin lokakuussa 1962, jolloin voin ja margariinin hintasuhteen sääntely siirtyi tapahtuvaksi tuontimaksujärjestelmän avulla.

Vuonna 1971 otettiin tuontimaksujen rinnalle käyttöön valmisteverotus voin ja margariinin hintasuhteen sääntelyssä jääkaappimargariinien osalta. Muiden ravintorasvojen osalta sen sijaan tuontimaksujärjestelmä oli edelleen yksinomainen keino säännellä voin ja margariinin hintasuhdetta.

Laki eräiden margariinien valmisteverosta oli voimassa vuoden 1977 loppuun. Se kumottiin vuonna 1978 voimaan tulleella lailla eräiden ravintorasvojen valmisteverosta. Tuolloin ravintorasvojen tuontimaksu korvattiin valmisteverolla, johon lisäveron muodossa sisällytettiin myös jääkaappimargariineista kannettu valmistevero. Koska tällainen tuontimaksu oli asiallisesti vastannut valmisteveroa, pidettiin tarkoituksenmukaisena muuttaa se muodollisestikin valmisteveroksi. Ravintorasvojen valmisteveron tarkoituksena oli nyt paitsi säännellä voin ja margariinin hintasuhdetta myös tasata maailmanmarkkinahintojen muutoksia.

Ravintorasvojen valmisteverojärjestelmä säilyi vuonna 1980 voimaan tulleessa ravintorasvaverolaissa pääosin entisenlaisena. Jääkaappimargariinien lisäveron kantamisesta luovuttiin vuonna 1981. Jotta margariinien keskimääräinen hintataso ja ravintorasvaveron tuotto eivät olisi lisäverosta luopumisen johdosta alentuneet, korotettiin vastaavasti ravintorasvaveron perusveroa.

Verotuksen perusteet muuttuivat 1980- ja 1990-lukujen vaihteessa, kun hintavalvontalain voimassaoloa ei enää jatkettu. Koska teollisuudella oli tämän jälkeen vapaammat mahdollisuudet märitellä tuotteidensa hinnat, ei ravintorasvaveroa voitu käyttää samalla tavalla kuin aikaisemmin voin ja margariinin hintasuhteen sääntelemiseen. Ravintorasvaveron kantamisesta ei silti luovuttu, vaan verotukselle asetettuja tavoitteita muutettiin niin, että tarkoitus oli tukea kotimaista rypsintuotantoa.

Laki ravintorasvaverosta oli voimassa vuoden 1994 loppuun saakka, jolloin se Suomen EU-jäsenyyteen liittyen kumottiin. Ravintorasvaveron tavoitteet olivat ennen EU-jäsenyyttä sellaisia, että verotus 
olisi ollut periaatteessa mahdollista järjestää kansallisella valmisteverolla. Verotuksen valvonnan käytännön toteuttamiseen katsottiin kuitenkin liittyvän sellaisia ongelmia, ettei veron säilyttämistä pidetty perusteltuna.

\subsubsection{Elintarvikkeiden valmistevero}

Elintarvikkeiden valmistevero, jota kannettiin vuodesta 1954, oli maatalouspoliittinen vero. Se liittyi myös vapaakauppasopimuksiin. Suomen ja EFTAn välillä vuonna 1961 solmitussa sopimuksessa Suomi sitoutui asteittain alentamaan ja lopulta poistamaan tullin kaikilta teollisuustuotteina pidettäviltä tuotteilta. Teollisuustuotteiksi katsottiin myös huomattava osa elintarviketeollisuuden valmistamista tuotteista. Elintarviketeollisuuden käyttämien maataloudesta saatavien raaka-aineiden hintataso oli Suomessa merkittävästi maailmanmarkkinahintoja korkeampi, joten tullisuojan asteittain poistuessa kotimaisen elintarviketeollisuuden kilpailukyky olisi vaarantunut, ellei kotimaisten ja maailmanmarkkinahintojen erosta tuontitavaroille aiheutuvaa etua olisi eliminoitu.

Vuonna 1964 voimaan tulleella lailla eräiden leipomotuotteiden valmisteverosta otettiinkin käyttöön yhdistetty valmisteverojärjestelmä ja raaka-aineiden hinnanerojen tasausjärjestelmä, jossa kannettiin sekä kotimaassa valmistetuista että maahan tuoduista leipomotuotteista samansuuruista valmisteveroa. Kotimaisella valmistajalla oli kuitenkin oikeus saada korvauksena kyseisten tuotteiden valmistuksessa käytettyjen raaka-aineiden kotimaisten ja maailmanmarkkinahintojen erotusta vastaava määrä. Näin sai elintarviketeollisuus vapaakauppasopimuksen perusteella tullittomiin tuotteisiin käyttämänsä maataloudesta saatavat raaka-aineet käytännössä maailmanmarkkinahintaan.

Hinnanero suoritettiin kotimaiselle valmistajalle myös maasta viedyistä tuotteista, vaikka nämä tuotteet olivatkin valmisteverosta vapaat. Näin pyrittiin turvaamaan järjestelmän piiriin kuuluvien elintarvikkeiden vienti ja suomalaisen elintarviketeollisuuden kilpailukyvyn säilyminen myös maailmanmarkkinoilla.

Järjestelmää sovellettiin aluksi vain eräisiin leipomotuotteisiin, mutta myöhemmin sen soveltamisalaa laajennettiin useaan kertaan. 
Valmistevero säädettiin samansuuruiseksi kuin oli asianomaisten tuotteiden valmistuksessa käytettyjen maatalousperäisten raaka-aineiden kotimarkkinahinnan ja maailmanmarkkinahinnan välinen ero. Täten kotimaiset valmistajat eivät joutuneet maksamaan valmisteveroa tai anomaan palautusta, koska valmistevero ja vähennettävä hinnanero olivat yhtä suuret.

Vuonna 1980 tuli voimaan pysyvä laki elintarvikkeiden valmisteverosta. Se vastasi sisällöltään paljolti aikaisempia lakeja. Lakia muutettiin sen voimassaoloaikana useita kertoja. Esimerkiksi vuonna 1983 muutettiin kotimaiselle valmistajalle verottomista toimituksista suoritettava hinnanerokorvaus harkinnanvaraiseksi.

Vuonna 1994 tuli voimaan uusi laki elintarvikkeiden valmisteverosta. Kysymyksessä oli osa maataloustuotannon sääntelyjärjestelmien kokonaisuudistusta, jolla muun muassa kehitettiin tuontimaksu- ja hinnanerokorvausjärjestelmiä EU:ssa käytössä olevien järjestelmien kaltaisiksi. Uudistukseen vaikutti myös muu kansainvälinen kehitys eli ETA-sopimuksen voimaantulo ja GATTin Uruguayn kierros.

Uudistuksessa aikaisemmat elintarviketuotteiden valmisteverotukseen yhdistetyt jalostettujen raaka-aineiden viennin yhteydessä suoritettavat hinnanerokorvaukset siirrettiin maataloustuotteiden hinnanerokorvauksista annetun uuden lain piiriin. Lisäksi huomattava osa aikaisemman lain tuotevalikoimasta siirrettiin tuontimaksulain alaisuuteen. Elintarviketuotteiden valmisteverolain piirissä säilyivät ne tuotteet, joiden GATT-sidonnaisuudet eivät sallineet tuontimaksun kantamista.

Elintarviketuotteiden valmisteverosta annettu laki kumottiin vuoden 1995 alusta Suomen liittyessä Euroopan unioniin. EU-jäsenyyden myötä Suomessa otettiin käyttöön EU:n tuontimaksujärjestelmä, jolla oli sama tarkoitus kuin oli ollut elintarvikkeiden valmisteverolla. Tuontimaksujen avulla nostettiin maatalousalkuperää olevien raakaaineiden hinta kotimarkkinatasolle. 


\subsubsection{Rehuverot}

Maatalouspoliittisia valmisteveroja olivat myös rehuveromme. Voin kulutuksen lisäämiseen ja pääasiassa ulkomaisista raaka-aineista valmistetun margariinin kulutuksen vähentämiseen pyrittiin vuonna 1934 säätämällä valmisteveron alaisiksi Suomessa tehdasmaisesti kauppaa varten valmistetut sekä ulkomailta tuodut margariinivalmisteet. Verotus ulotettiin koskemaan myös eräitä rehuaineita. Tultaessa 1940-luvun alkuun karjataloustuotteiden hinnat olivat nousseet niin, että vero ei olisi enää ollut tarpeen voin hinnan vakaannuttamiseksi. Verosta ei kuitenkaan luovuttu, vaan lain voimassaoloa jatkettiin vielä vuosiksi 1941 ja 1942, koska veron kantamista pidettiin tarpeellisena valtiontaloudellisista syistä.

Vuonna 1976 samaan aikaan lannoitteiden valmisteverotuksen kanssa Suomessa otettiin käyttöön rehuseosten valmistevero. Tätä veroa kannettiin vuoden 1977 loppuun. Maatalouden ylituotannon kasvuun 1970-luvulla oli vaikuttanut muun muassa tehdasvalmisteisten rehuseosten käytön lisääntyminen. Valmisteveron tavoitteena oli, että maatalous osallistuisi ylituotannon markkinoinnista aiheutuviin kustannuksiin. Toisaalta verolla pyrittiin ohjaamaan kotieläintuotannon laajuutta ja rakennetta. Tarkoituksena oli vaikuttaa kotieläintuotannon laajuuteen erityisesti vähentämällä kiinnostusta laajentaa valmiiden rehuseosten käyttöön perustuvaa teollismaista kotieläintuotantoa.

Suomessa on kannettu valmisteveroa myös öljyväkirehuista. Veron tarkoituksena oli tasata öljyväkirehujen raaka-aineiden maailmanmarkkinahintojen muutosten vaikutuksia öljyväkirehujen kotimarkkinahintoihin. Öljyväkirehujen maailmanmarkkinahintoja tasattiin nostamalla valmisteveroa maailmanmarkkinahintojen laskiessa ja alentamalla veroa maailmanmarkkinahintojen noustessa. Laki öljyväkirehujen valmisteverosta tuli voimaan vuonna 1978. Aikaisemmin öljyväkirehujen hintataso oli pidetty kotimaassa vakaana kantamalla öljyväkirehuista tuontimaksua. Tuontimaksujärjestelmän uudistamisen yhteydessä pidettiin tarkoituksenmukaisena muuttaa tuontimaksu tältä osin öljyväkirehujen valmisteveroksi, koska ei pidetty verotuksellisesti onnistuneena sitä, että sekä tuontituotteista että kotimaisista 
tuotteista kannettavaa valmisteveroa tosiasiallisesti vastaavan maksun nimi oli tuontimaksu.

Uusi laki öljyväkirehusta annettiin vuonna 1979. Se vastasi paljolti aikaisempaa lakia. Veron tavoitteiden osalta tuotiin jälleen esiin veron asema öljyväkirehujen hintojen tasaajana. Toisaalta perusteluissa viitattiin nyt myös siihen, että öljyväkirehuveron tuotto muodostaisi osan siitä maatalouden osuudesta, jolla maatalouden oli osallistuttava ylituotannon viennin rahoittamiseen. Öljyväkirehuveron kannosta luovuttiin vuoden 1987 alusta. Lain kumoamista perusteltiin sillä, että vero oli menettänyt alkuperäisen merkityksensä öljyväkirehujen hintojen tasaajana. Tämä johtui rehujen hinnoittelukäytännön muuttamisesta siten, että raaka-ainehintojen muutosten annettiin nyt heijastua suoraan öljyväkirehujen hintoihin. Öljyväkirehuverolla todettiin myös olleen vähäinen merkitys maataloustulolaissa tarkoitetun maatalouden osuuden keräämisen kannalta.

Vuonna 1981 kannettiin öljyväkirehujen valmisteveron ohella erillistä valmisteveroa valkuaisrehuista. Se tuli voimaan maaliskuussa 1981 ja oli voimassa saman vuoden loppuun. Myös valkuaisrehuvero muodosti osan sitä järjestelmää, jolla katettiin maatalouden osuutta ylituotannon markkinointikustannuksista. Veron tavoitteena oli samalla rajoittaa ylituotantoa ja edistää maataloudessa oman pellon käyttöön perustuvaa valkuaisrehutuotantoa ja sen hyväksikäyttöä. Valkuaisrehut tulivat valmisteverotuksen piiriin seuraavan kerran vuonna 1986, ja laki valkuaisrehusta oli voimassa vuoden 1990 loppuun. Veron tuotolla oli tarkoitus osittain rahoittaa maataloustuotteiden vientikustannuksia. Ensisijaisena tavoitteena voitiin kuitenkin pitää sitä, että valkuaisverolla pyrittiin säätelemään perusrehujen ja valkuaisrehujen välistä hintasuhdetta. Jotta rehuviljan kotimainen käyttö olisi jälleen lisääntynyt ja vientitarve supistunut, valkuaisrehujen hintoja oli korotettava.

Vuosina 1983-1988 kannettiin taas valmisteveroa myös rehuseoksista. Vero oli jälleen osa sitä markkinointimaksu- ja valmisteverojärjestelmää, jolla kerättiin maatalouden osuus maataloustuotteiden ylituotannon markkinoinnista valtiolle aiheutuvista menoista. Toisaalta verolla oli tarkoitus rajoittaa maatalouden ylituotantoa ja edistää maataloudessa oman pellon käyttöön perustuvaa tuotantoa. Laki rehuseosverosta muistutti rakenteeltaan ja sisällöltään paljon 
vuonna 1976 säädettyä rehuseosten valmisteverolakia. Maatalouden ylituotanto supistui 1980-luvun lopulla niin, että kannettavan rehuseosveron määrää voitiin alentaa, ja veron kantamisesta luovuttiin kokonaan heinäkuussa 1988. Käännekohtana oli vuoden 1987 kato. Rehuseosveron ei-fiskaalista luonnetta kuvastaa hyvin se, että veron kantamisesta luovuttiin aikaisemmin kuin oli alun perin suunniteltu.

Vuonna 1986 voimaan tullut valkuaisverolaki kumottiin vuonna 1991 voimaan tulleella lailla rehujen rasva- ja valkuaisverosta, jonka voidaan katsoa sisältäneen periaatteessa kaksi veroa: rehujen rasvaveron ja rehujen valkuaisveron. Veroa perusteltiin sillä, että maataloustuotteiden ylituotantotilanteen jatkuessa vientitarve oli säilynyt korkeana. Rehujen rasva- ja valkuaisverosta annetun lain tarkoituksena oli toisaalta korjata rasva- ja valkuaisrehujen hintasuhteita vastaamaan paremmin perusrehujen hintoja, toisaalta edistää perusrehujen käyttöä ja näin vähentää rehuviljan vientitarvetta ja viennistä aiheutuvia kustannuksia. Lain tavoitteet eivät siis juuri muuttuneet niistä tavoitteista, jotka oli asetettu vuodesta 1986 lähtien kannetulle valkuaisverolle.

Laki rehujen rasva- ja valkuaisverosta kumottiin vuoden 1995 alusta. Kun EU-järjestelmässä maataloustuotteiden vientiin liittyviä tukia ja hinnanerokorvauksia ei maksettu kansallisista varoista, ei rehujen rasva- ja valkuaisveroa enää tarvittu vientikustannusten kattamiseen. Veroon oli tosin liittynyt muitakin tavoitteita, mutta tältä osin veron kumoamista perusteltiin sillä, että EU:ssa ei yhteisen maatalouspolitiikan piirissä ole rehuilla vastaavaa veroa, jolloin rehuista ei kilpailuvääristymien ehkäisemiseksi tullut kantaa veroa myöskään Suomessa.

\subsubsection{Lannoiteverot}

Lannoiteverojemmekin syyt olivat lähinnä maatalouspoliittisia. Ensimmäinen laki lannoitteiden valmisteverosta tuli voimaan heinäkuussa 1976. Maatalouden ylituotanto kasvoi 1970-luvulla voimakkaasti, ja tähän vaikutti osaltaan lannoitteiden käytön lisääntyminen. Kantamalla lannoitteiden valmisteveroa pyrittiin hidastamaan lannoitteiden käytön kasvuvauhtia ja siitä aiheutuvaa ylituotantoa. Veron 
ensisijaisena tavoitteena kuitenkin oli, että maatalous osallistui valmisteveroilla ylituotannon markkinoinnista aiheutuviin kustannuksiin.

Laki ei ollut pysyvä, mutta sen voimassaoloa jatkettiin, koska jatkamista pidettiin edelleen tarpeellisena ylituotannon markkinoinnin rahoittamiseksi ja ylituotannon supistamiseksi. Uusi laki lannoiteverosta oli voimassa vuoden 1981 loppuun. Sen voimassaoloa jatkettiin vuodesta 1982 vuoteen 1988 aina vuodeksi kerrallaan. Lannoiteveron määrä vaihteli sen mukaan, minkä verran maatalouden ylituotannon viennistä aiheutuvien menojen rahoittamiseen kulloinkin tarvittiin.

Lannoitteiden valmisteverotusta jatkettiin myös vuonna 1989. Veron tuotolla oli aikaisemmin katettu osa maatalouden osuudesta maataloustuotteiden vientikustannuksia, mutta nyt sillä oli tarkoitus kattaa myös osa maatalouden osuudesta maataloustuotannon ohjaamis- ja tasapainottamismenoista sekä osa puutarhatuotteiden ja ylijäämäperunoiden markkinoinnin edistämiseen käytettävistä menoista. Pitkäjännitteisen hinta- ja veropolitiikan sekä tuotannon ohjaamiseen tähtäävien tavoitteiden kannalta pidettiin perusteltuna, että lannoitevero ei vaihdellut ylituotantotilanteen mukaan vaan sillä katettiin myös muita kuin ylituotannon viennistä aiheutuvia kustannuksia.

Laki fosforilannoiteverosta tuli voimaan vuonna 1990. Kysymyksessä oli ensimmäinen yksinomaan ympäristöpoliittisista syistä säädetty valmistevero maassamme. Erillinen fosforilannoitevero poistettiin kuitenkin vuoden 1992 alusta, jolloin lannoiteverosta ja fosforilannoiteverosta annetut lait yhdistettiin yhdeksi lannoiteverosta annetuksi laiksi. Uudistuksen tarkoituksena oli entistä enemmän ottaa ympäristöpoliittiset tekijät huomioon lannoitteiden valmisteverotuksessa, kun vero nyt määräytyi lannoitteen typpi- ja fosforisisällön perusteella. Lannoitteiden ympäristölle aiheuttamat ongelmat liittyvät nimenomaan typpi- ja fosforipäästöihin.

EU-jäsenyyttä ennakoiden kumottiin vuoden 1994 heinäkuun alusta lannoiteverosta annettu laki. Lannoitevero kumottiin, kun sitä ei enää jäsenyystilanteessa tarvittu maatalous- ja elintarviketuotteiden viennistä aiheutuvien kustannusten korvaamiseen. Lannoiteveron ympäristöpoliittiset tavoitteet katsottiin voitavan saavuttaa siten, että jäsenyystilanteessa viljan hinnan alentuessa alenee myös lannoitteiden edullisin käyttömäärä hehtaaria kohti. 


\subsubsection{Polttoainevero}

Nestemäisten polttoaineiden verotus Suomessa aloitettiin 1920-luvulla tullin kantamisella maahan tuoduista polttonesteistä. Kun Suomessa vuonna 1957 aloitettiin oma öljynjalostustoiminta, lainsäädäntöä jouduttiin täydentämään, jotta kotimaassa valmistetut nestemäiset polttoaineet olisivat tulleet samanlaisen verotuksen kohteeksi kuin vastaavat maahan tuotavat ulkomaiset tuotteet. Tällöin säädettiin laki nestemäisten polttoaineiden valmisteverosta. Se tuli voimaan saman vuoden heinäkuussa.

1960-luvun puolivälissä luovuttiin ajoneuvoveron kantamisesta bensiinikäyttöisistä ajoneuvoista ja alennettiin dieselkäyttöisten ajoneuvojen ajoneuvokohtaista veroa. Tästä aiheutunut verotulojen menetys korvattiin bensiinin ja dieselöljyn valmisteverolla.

Nestemäisten polttoaineiden verotuksessa oli pitkään voimassa järjestelmä, jossa valmisteveron perusveroa kannettiin vain Suomessa valmistetuista tuotteista ja maahan tuoduista tuotteista kannettiin vastaavasti tullia. Järjestelmää muutettiin Suomen solmittua Euroopan talousyhteisön kanssa vuonna 1973 sopimuksen, jossa edellytettiin bensiinin tullia alennettavaksi asteittain niin, että se poistuisi vuonna 1977 kokonaan. Jotta valtion verotulot eivät olisi alentuneet, bensiinin tulli korvattiin valmisteveron perusverolla.

Raakaöljyn maailmanmarkkinahinnan voimakas nousu vuodenvaihteessa 1973-1974 aiheutti muutoksia polttoaineiden verotusjärjestelmään. Pääosa polttoaineista oli ollut liikevaihtoveron alaista. Koska liikevaihtovero oli prosentuaalinen vero, joka määräytyi lopullisen kuluttajahinnan perusteella, vaikuttivat hinnoissa tapahtuneet muutokset välittömästi veron märään. Tällöin vero lisäsi hintojen noustessa vähittäismyyntihintaan kohdistuvaa painetta. Tilanteen katsottiin muodostuneen kestämättömäksi esimerkiksi elinkeinoelämän toimintamahdollisuuksien ja työllisyyden kannalta. Tämä polttoaineiden hintojen nousun kertautuminen verotuksen kautta estettiin siten, että luovuttiin prosentuaalisesta liikevaihtoverosta ja siirryttiin markkamääräiseen yksikköperusteiseen valmisteveroon.

Vuonna 1986 toteutettiin merkittävä energiaverouudistus, jossa pääasiassa valmisteverotukseen perustuvasta verotuksesta siirryttiin liikevaihtoverotukseen. Hallituksen esitys pohjautui paljolti energia- 
verotoimikunnan vuonna 1983 jättämään mietintöön. Energiaverotuksen muutostarpeita arvioidessaan toimikunta kiinnitti huomiota muun muassa siihen, että energiaverotus kohdistui erisuuruisena eri energialähteisiin. Liikennepolttonesteiden hinnasta energiaverojen osuus oli tuolloin noin $30 \%$, kun taas muiden energialajien hinnoista energiaverojen osuus oli 2-9\%. Tähän oli vaikuttanut se, että yksittäisten valmisteverojen suuruutta päätettäessä olivat olleet usein etusijalla valtiontaloudelliset näkökohdat, jolloin energiaverot olivat painottuneet tuottavimpiin kohteisiin. Toimikunta korosti samaan käyttötarkoitukseen käytettävien energiamuotojen tasapuolisen verotuksen tärkeyttä. Teollisuuden kansainvälisen kilpailukyvyn kannalta toimikunta piti ongelmallisena sitä, että kilpailijamaissa kannettiin pääosa energiaveroista arvonlisäverona, joka ei jää rasittamaan vientituotteita.

Uudistuksen jälkeen ainoastaan liikennepolttonesteistä eli moottoribensiinistä ja dieselöljystä kannettiin liikevaihtoveron lisäksi valmisteveroa. Käytännössä uudistus merkitsi noin miljardin markan kevennystä tuotannollisen toiminnan energiakustannuksiin. Toisaalta vastaavan suuruinen verorasitus siirtyi muiden energiaa kuluttavien tahojen, lähinnä palvelutuotannon ja kotitalouksien, kannettavaksi.

Vuoden 1986 uudistus oli merkittävä myös siksi, että ympäristöpoliittiset tavoitteet nyt ensi kertaa tulivat huomioon otetuiksi polttoaineiden valmisteverotuksessa. Tämä tapahtui porrastamalla moottoribensiinin vero siten, että lyijyttömästä eli ympäristölle vähemmän haitallisesta bensiinistä suoritettava vero oli alempi kuin muusta bensiinistä suoritettava vero. 1990-luvun alusta polttoaineiden valmisteverotuksessa ympäristöpoliittiset tavoitteet olivat esillä korostetummin. Energian kulutuksen kasvun hillitsemiseksi sekä energiantuotannosta ja -kulutuksesta aiheutuvien ympäristöhaittojen vähentämiseksi alettiin kantaa valmisteveroa muistakin fossiilisista polttoaineista kuin bensiinistä ja dieselöljystä. Veron piiriin tulivat kivihiili ja ruskohiili, jyrsinturve, kevyt ja raskas polttoöljy sekä maakaasu. 


\subsubsection{Polttoainemaksu}

Hyväksyessään vuonna 1959 nestemäisten polttoaineiden valmisteverotuksesta annetun lain muuttamisen eduskunta edellytti hallituksen kiinnittävän erityistä huomiota verotuksen valvontaan. Oli estettävä dieselöljyn osalta tapahtuva verotuksen välttäminen, jonka mahdollisti se, että polttoöljy saattoi olla käytännössä samaa tuotetta kuin dieselöljy. Koska dieselöljystä kannettiin korkeampaa valmisteveroa kuin polttoöljystä, kansalaisilla oli houkutus käyttää polttoöljyä dieselkäyttöisten ajoneuvojen polttoaineena. Sinänsä polttoöljyn käyttö dieselajoneuvoissa ei ollut verotuksen kannalta kiellettyä.

Nestemäisten polttoaineiden valmisteverosta annetun lain täytäntöönpanosta ja soveltamisesta annettuun asetukseen sisällytettiin säännös polttoöljyn värjäämisestä sen erottamiseksi dieselöljystä. Väriaineen tarkoituksena oli tehdä polttoöljy kevyissä dieselmoottoreissa käyttökelvottomaksi. Tavoitteena oli myös tehdä polttoöljy tunnistettavaksi, jotta olisi pystytty seuraamaan polttoöljyn ja dieselöljyn kulutusta sekä erityisesti polttoöljyn käyttötarkoituksia. Värjäämismenettelyllä ei kuitenkaan saavutettu sille asetettuja tavoitteita, vaan päinvastoin aiheutettiin vaikeuksia polttoöljyn käytölle sallittuihin tarkoituksiin.

Kun värjäämismenettely epäonnistui ja kun polttoöljyä toisaalta oli entistä enemmän alettu käyttää polttoaineena dieselöljyn asemesta, etsittiin uusia keinoja ongelman ratkaisemiseksi. Vuonna 1960 annetussa hallituksen esityksessä ehdotettiin verotulojen vähenemisen estämiseksi, että polttoöljyn käyttö tiettyjen dieselmoottoreiden polttoaineena olisi säädetty rangaistavaksi teoksi. Hallitus kuitenkin peruutti esityksensä sen jälkeen, kun lakivaliokunta oli lausunnossaan esittänyt sen hylkäämistä. Valiokunta ei pitänyt periaatteelliselta kannalta suotavana, että kansalaisia olisi kielletty käyttämästä vapaasti saatavissa olevaa hyödykettä yksinomaan siksi, että valtiolle kertyisi verotuloja. Tällaiselta määräykseltä katsottiin edellytettävän, että se olisi välttämätön jonkin yleisen tärkeän edun saavuttamiseksi ja että sen tehokas valvominen olisi mahdollista.

Vuoden 1961 alusta moottoriajoneuvoverolakiin lisättiin säännökset erityisestä lisäverosta. Polttoöljyn käyttö myös moottoriajoneuvoissa oli yhä sallittua, mutta siitä oli suoritettava lisäveroa. Vero 
säädettiin tarkoituksellisesti niin korkeaksi, että ajoneuvoa tultaisiin käyttämään polttoöljyllä vain poikkeuksellisesti. Luodun verojärjestelmän valvonnan kannalta oli tärkeää, että polttoöljy voitiin helposti ja varmasti erottaa dieselöljystä. Uudistuksen yhteydessä siirryttiin polttoöljyn merkitsemiseen furfuraali-nimisellä aineella.

Moottoriajoneuvoveron lisävero oli Suomessa rekisteröityjen ajoneuvojen osalta tehokas keino turvata ajoneuvojen käyttö niille tarkoitetulla polttoaineella ja valmisteverojen suorittaminen. Tuolla lisäverolla ei kuitenkaan yleensä voitu estää polttoöljyn käyttöä ulkomaisissa ajoneuvoissa. Tämä johtui siitä, että kansainvälisten tieliikennesopimusten vuoksi ulkomailla rekisteröidyille ajoneuvoille ei lisäveroa yleensä voitu panna maksuun. Näissä sopimuksissa Suomi oli sitoutunut olemaan kantamatta muussa sopimusmaassa rekisteröidyiltä ajoneuvoilta veroja muun muassa ajoneuvon hallinnan perusteella. Lisävero katsottiin oikeudelliselta luonteeltaan tällaiseksi hallinnan perusteella kannettavaksi veroksi.

Kotimaassa rekisteröityjen ajoneuvojen ja ulkomailla rekisteröityjen ajoneuvojen erilainen verokohtelu ei ollut iso ongelma vielä silloin, kun ulkomaisten ajoneuvojen liikenne Suomessa oli rajoitettua, vain rajat ylittävää liikennettä. Uuteen tilanteeseen jouduttiin, kun liikennettä koskevia rajoituksia 1990-luvulla ryhdyttiin kansainvälisesti purkamaan. Kun ulkomailla rekisteröidyt ajoneuvot alkoivat tavarankuljetuksessa todella kilpailla Suomen sisäisessä liikenteessä, ei polttoöljyn käyttömahdollisuutta voitu enää entisillä tavoilla kompensoida kotimaisille liikenteenharjoittajille. Kilpailuedellytysten tasoittaminen edellytti joko sitä, että ulkomailla rekisteröidyissä ajoneuvoissa oli käytettävä Suomessa ajettaessa dieselöljyä, tai sitä, että sellaisen ajoneuvon käytöstä oli muulla tavoin suoritettava vastaava määrä veroa. Muutoksen tarve koski välittömästi kuorma- ja linjaautoja. Ympäristösyistä pidettiin parempana edistää moottorikäyttöön kehitetyn polttoaineen käyttöä dieselajoneuvoissa ja siten myös verotuksella rajoittaa kevyen polttoöljyn käyttöä ulkomailla rekisteröidyissä raskaissa ajoneuvoissa. Näistä syistä vuonna 1993 säädettiin laki polttoainemaksusta. Se koski myös suomalaisia ajoneuvoja, eikä polttoainemaksu vapauttanut moottoriajoneuvoveron lisäveron suorittamisesta, mutta lisäverosta vähennettiin polttoainemaksun osuus. 


\subsubsection{Sähkövero}

Suomessa kannettiin valmisteveroa sähköstä ensi kerran vuosina 1976-1986. Sähköveron säätämistä perusteltiin sähköenergian saattamisella tasavertaiseen asemaan muiden energiamuotojen kanssa. Sähkö oli tuolloin ainoa merkittävä sellainen energialähde, josta ei kannettu mitään veroa. Toisaalta pyrkimyksenä oli hillitä sähköenergian kulutuksen kasvua. Veron säätämistä perusteltiin myös valtiontaloudellisilla syillä. Sähköveroa kannettiin sekä Suomessa tuotetusta nettosähköenergiasta että maahan tuodusta sähköenergiasta.

Sähköveron kantamisesta luovuttiin vuonna 1986, jolloin energiaverotuksessa siirryttiin liikevaihtoverotukseen. Sähköveroa alettiin kantaa jälleen vuoden 1993 alussa, ja uusi sähkövero oli entisen kaltainen. Lain pääasialliset tavoitteet olivat valtiontaloudellisia, toissijaiset syyt olivat energia- ja ympäristöpoliittisia.

\subsubsection{Kulta- ja hopeaverot}

Sodan jälkeen 1940-luvun loppupuolella Suomeen säädettiin valmisteveroksi luokiteltavat kultavero ja hopeavero. Laki kotimaassa tuotetun kullan verosta tuli voimaan 15.12.1945 ja laki kotimaassa tuotetun hopean verosta 1.7.1947. Taustalla vaikuttivat sodan aiheuttamiin poikkeuksellisiin oloihin liittyvät syyt, jotka eivät kuitenkaan olleet suoranaisesti valtiontaloudellisia vaan liittyivät kotimaassa tuotetun kullan ja hopean hintasäännöstelyyn ja keinottelun ehkäisemiseen. Veroilla pyrittiin vaikuttamaan kullan ja hopean hintakehitykseen. Sekä kultaverosta että hopeaverosta annetut lait kumottiin vuoden 1949 huhtikuun alusta, kun näille veroille asetetut tavoitteet oli saavutettu. 


\subsubsection{Koiravero}

Sodan aikana vuonna 1942 SDP:n lakialoitteessa ehdotettiin koiraveron korottamista muun muassa seuraavin perustein:

"Kun koiria, varsinkin kaupungeissa, on pidettävä tarpeettomina, ja kun ne osallistuvat supistuneiden elintarvikkeiden kulutukseen, on sitäkin suurempi syy niistä suoritettavaa veroa koroittaa eritoten, koska koiranomistajat ovat yleensäkin sellaisessa taloudellisessa asemassa olevia, ettei veron koroitus vaaranna heidän toimeentuloaan.”

Valiokunta piti veron korotusta tarpeellisena. Kohtuuteen viitaten se kuitenkin esitti verottomiksi sotasokeiden ja muidenkin opaskoirat. Eduskunta vapautti veron maksamisesta myös invalidit ja aistivialliset apu- ja opaskoiristaan sekä puolustuslaitoksen ja suojeluskunnat sotakoiristaan.

Koiraverotus uudistettiin vuonna 1979. Silloin todettiin, ettei vesikauhun leviämisen estämistä enää voitu pitää koiraverotuksen varsinaisena tarkoituksena, vaan koiraveron merkitys oli lähinnä fiskaalinen. Koirien lukumäärä oli kasvanut vapaa-ajan lisääntyessä ja elintason noustessa. Yhä suurempi koirakanta aiheutti kunnille yhä suurempia kuluja, esimerkiksi puhtaanapitokustannuksia ja palvelutoiminnoista aiheutuvia menoja.

Koiraverotus nousi vuonna 1990 julkisen keskustelun kohteeksi. Useat kunnat nimittäin tekivät aloitteen, että ne saisivat itse päättää, kantavatko ne koiraveroa vai eivät. Koiraveron enimmäismäärää pidettiin myös riittämättömänä veron kannosta aiheutuviin kustannuksiin nähden. Lakia muutettiinkin vuodesta 1991 lukien siten, että kunnanvaltuusto voi päättää, onko kunnassa suoritettava koiraveroa. Samalla koiraveron enimmäismäärää korotettiin.

Koiraveron on pelastanut kuolemalta sen luonteen muuttuminen ylellisyysverosta terveysveron kautta tietynlaiseksi päästö- ja jäteveroksi. Koiravero saa jonkinlaista hyväksyntää siksi, että sillä katsotaan voitavan kattaa koirien jätösten yhteiskunnallisia kustannuksia ja helpotettavan koiranomistajien vaatimuksia koirapuistoista ja muista kunnallisista palveluista. Koiravero on kuitenkin käynyt uhanalaiseksi, sillä sitä perii enää kaksi kuntaa. Nämä saattohoitajat ovat Helsinki ja Tampere. 


\subsubsection{Huviverotus}

Suomen itsenäistyminen ja sotatilan päättyminen eivät merkinneet huviverotuksen loppumista. Vuonna 1920 siirryttiin käyttämään leimamerkkejä, ja vuonna 1922 siirryttiin käyttämään valtion toimesta painettuja pääsylippuja.

Tansseista samoin kuin sirkusnäytännöistä oli 1920-luvulla yleensä suoritettava huviveroa $40 \%$ pääsylipun hinnasta. Veroa ei suoritettu tilaisuuksista, joiden pääasiallisena ohjelmana oli puheita, esitelmiä, lausuntaa, laulu- ja soittoesityksiä, näytelmiä yms. mutta joissa tanssia ohjelman päätyttyä oli enintään yhden tunnin ajan. Sodan jälkeen vuonna 1946 tanssien huvivero nostettiin jopa 50 \%:iin. Vuonna 1948 säädettiin sellainen helpotus, että verovapaassa tilaisuudessa sallittiin tanssia 1,5 tuntia. Tanssien huvivero alennettiin 1950-luvun lopulla 25-30\%:iin.

Urheilukilpailuista oli lähtökohtaisesti suoritettava veroa. Vuonna 1920 annetussa leimaverolaissa kuitenkin säädettiin, ettei tilaisuutta, jonka ohjelmana on yksinomaan voimistelu- ja urheiluesityksiä, katsottu huvitilaisuudeksi. Lakiin lisättiin 1930-luvulla säännökset korkeasta huviverosta auto- ja moottoripyöräkilpailuille sekä ammattinyrkkeilylle. Moottoriurheilukilpailujen huvivero oli 1950-luvun lopulta $15 \%$ ja ammattinyrkkeilyotteluiden $35 \%$. 1950-luvulla säädettiin huviverosta vapaiksi jalkapallo-, jääkiekko- ja koripallokilpailut, jos vain toisen osapuolen joukkueessa oli ammattilaisurheilijoita.

Huviverotus koski myös elokuvia. Elokuvanäytäntöjen veroprosenteissa otettiin vuoden 1921 lopulta asti huomioon ohjelmiston laatu. Kotimaista elokuvatuotantoa alettiin suosia 1930-luvulla. Elokuvien huviveron fiskaalinenkin merkitys oli 1950-luvulla hyvin huomattava.

Kotimainen elokuvatuotanto joutui 1950-luvun lopulla taloudellisiin vaikeuksiin, ja elokuvien huviverotusta kevennettiin. Elokuvateattereissa kävijöiden määrä kuitenkin aleni pääasiassa televisioiden yleistymisen vuoksi. Hallitus katsoi vuonna 1964, ettei ollut syytä poistaa elokuvien verotusta kokonaan. Säädettiin elokuvaverolaki, jossa elokuvien verotusta alennettiin ja elokuvat jaettiin kahteen ryhmään. Normaaliksi veroksi tuli $10 \%$, mutta heikkotasoisiksi luonnehdittujen eli käytännössä seksi- ja väkivaltaelokuvien veroksi tuli 
$30 \%$. Elokuvaveron tuottoa käytettiin kotimaisen elokuvatuotannon avustamiseen.

Uudistuksessa veron tuotto romahti. Vuoden 1969 lopulla opetusministeriö ja elokuva-alan järjestöt sopivat Suomen elokuvasäätiön perustamisesta. Säätiön rahoitukseen liittyen elokuvaverolakiin lisättiin säännös, jonka mukaan elokuvaveroa alennettiin, jos elokuvanäytännön toimeenpanija sitoutui suorittamaan Suomen elokuvasäätiölle tietyn osan näytännön pääsymaksusta. Veron tuotto laski tämän jälkeen entisestäänkin. Elokuvaveroa kertyi 1970-luvulla lähinnä vain seksielokuvien esittämisestä niihin keskittyneissä elokuvateattereissa.

Huhtikuussa 1979 tekivät SDP:n kansanedustajat lakialoitteen huviverotuksen kumoamisesta. Aloitteessa viitattiin siihen, että vapaa-ajan lisääntyessä ja sen vieton ongelmien kasvaessa oli kaikkialla maailmassa kiinnitetty vakavaa huomiota kansalaisten kokoontumismahdollisuuksiin ja huvituksiin. Edelleen todettiin, että huviverotus oli muissa Pohjoismaissa jo poistettu. Todettiin myös, että huvivero oli itse asiassa köyhän kansan vero ainakin sen jälkeen, kun ooppera, teatteri ja konsertit oli poistettu veron piiristä mutta sirkukset sekä tanssilavoilla ja seurojen- ja työväentaloilla pidettävät tanssit oli jätetty veronalaisiksi. Lakialoitteen tekijöiden mielestä ei ollut oikein, että yhteiskunta verotti tällaisesta vapaa-ajan käytöstä. Laki myös vaikeutti vapaa-ajan viihdemuotojen kehittämistä ja aikaansai epäterveitä muotoja lain kiertämiseksi.

Ravintolaelinkeinon elvyttämistoimenpiteenä luovuttiin keväällä 1979 ravitsemisliikkeiden aukioloajan ja tarjoilun pidentämistä koskevien lupapäätösten leimaverosta samoin kuin tanssi-, revyy- ja muiden niihin verrattavien ohjelmien lupapäätöksistä perittävästä leimaverosta, joka oli tavallaan korvannut näiden tilaisuuksien huviveron. Hyväksyessään tätä koskevan hallituksen esityksen eduskunta edellytti hallituksen selvittävän, millä toimenpiteillä huvitilaisuuksia järjestävien yhteisöjen toimintaedellytyksiä voitaisiin parantaa.

Kesällä 1980 hallitus antoi esityksen huviverotusta koskevien säännösten muuttamisesta. Esityksen perusteluissa todettiin, että noin $80 \%$ huviveron tuotosta muodostui yleishyödyllisten yhteisöjen järjestämien tanssitilaisuuksien pääsylipuista suoritettavasta verosta ja että juuri tanssitilaisuuksien järjestäminen olikin näiden yhteisöjen tärkeä rahoitusmuoto. Hallitus esitti huviveron poistamista yleis- 
hyödyllisten yhteisöjen toimeenpanemiin tanssitilaisuuksiin myytäviltä pääsylipuilta.

Valtiovarainvaliokunta käsitteli samalla kertaa hallituksen esityksen kanssa myös edellä mainittua SDP:n kansanedustajien lakialoitetta. Valiokunta päätti sen pohjalta ehdottaa koko huviverotuksen poistamista. Huviverotuksen kumoava leimaverolain muutos hyväksyttiinkin, ja se tuli voimaan vuoden 1981 alusta.

Valtiovarainministeriö asetti vuoden 1981 alussa työryhmän selvittämään, olisiko huviverosta luopumisen johdosta aiheellista kumota myös elokuvaverotus. Työryhmä totesi elokuvaveroa kertyvän käytännössä vain $30 \%$ :n elokuvien (seksi- ja väkivaltaelokuvat) esittämisestä. Veron tuotto oli vähäinen, eikä elokuvaveron kumoamisella siltä kannalta ollut merkitystä. Koska 30 \%:n elokuvavero oli merkittävä kulttuuripoliittinen elokuvien esitys- ja levitystoiminnan säätelykeino, olisi sen kumoaminen työryhmän mielestä merkinnyt supistusta yhteiskunnan mahdollisuuksiin rajoittaa heikkotasoisten elokuvien levitys- ja esitystoimintaa. Jos elokuvavero olisi poistettu, olisi elokuvien ennakkotarkastusperusteita pitänyt laajentaa. Työryhmä totesi myös, että Suomen elokuvasäätiön toiminnan rahoitus oli säätiömaksun tuoton kautta olennaisesti kytketty elokuvaverolakiin. Lain kumoaminen olisi merkinnyt tällaisen lakiin sidotun veronalennusmahdollisuuden ja siihen liittyvän säätiömaksupakotteen häviämistä. Työryhmä ei pitänyt mahdollisena eikä tarkoituksenmukaisena kumota elokuvaverolakia siinä vaiheessa.

Elokuvaveron tuotto pienentyi entistäkin olemattomammaksi 1980-luvun puolivälistä alkaen. Se johtui muun muassa videolaitteiden yleistymisestä: seksielokuvien katsominen siirtyi elokuvateattereista omiin asuntoihin. Elokuvaverotus kumottiin lopuksi vuonna 1994. Hallituksen esityksessä todettiin, että rangaistusvero elokuvateattereiden ohjelmiston laatuun vaikuttavana tekijänä oli menettänyt merkitystään. Säätiömaksulla ei ollut enää Suomen elokuvasäätiön talouden kannalta samaa merkitystä kuin aikaisemmin, sillä maksu kattoi vain vähäisen osan säätiön rahoituksesta. Eduskunnalle oli annettu esitys arvonlisäverolaiksi, jossa ehdotettiin elokuvanäytöksistäkin suoritettavaksi kyseistä veroa. Kun ei ollut kohtuullista, että elokuvateatterit olisivat joutuneet suorittamaan myös säätiömaksua, elokuvaverosta luovuttiin ja elokuvaverolaki kumottiin. Suomen elo- 
kuvasäätiön toiminta rahoitettiin osoittamalla sille valtion talousarviossa määräraha.

\subsubsection{Pelikorttivero}

Pelikorttiverotus säilyi Suomen itsenäistymisen jälkeenkin. Pelikorttiverotuksen yhteydessä viitattiin muun muassa ylellisyysveronäkökohtaan. Leo Harmaja kirjoitti vuonna 1923 pelikorttiveron taustasta seuraavasti: "Verotuksen aiheena on se ylellisyyteen luettava kulutus, jota pelin harjoittaminen tavallisesti merkitsee. Erikoisen verotuksen myönnetään jotenkin yleisesti tässä olevan paikallaan, mutta toiselta puolen pidetään kohtuuden vaatimana, ettei veroa määrätä kovin korkeaksi, mikä voisi tuntua liian rasittavalta, jos pelikortteja käytetään vain viattomaan ajanviettoon perhepiirissä.”

Harmaja kytki liian korkean pelikorttiveron ongelmiin myös nykyyhteiskunnan kannalta kiinnostavan terveyspoliittiseksi luokiteltavan näkökohdan todetessaan: "On myös muistettava, että veron ollessa tuntuva pidetään samoja pelikortteja kauan käytössä, mikä saattaa olla epäsiistiä, jopa epäterveellistä.”

Pelikorttivero kumottiin Suomessa vasta vuonna 1983. Verosta luopumista perusteltiin muun muassa veronkantomenettelyn ongelmilla. Hallituksen esityksessä viitattiin esimerkiksi valvontaongelmiin matkustajien mukanaan tuomien pelikorttien osalta. Harva matkustaja tiesi ostaessaan aluksilla yleisesti myytävänä olevan korttipakan, että kortit olisi ollut ilmoitettava tullissa leimaveron maksamista varten.

\subsubsection{Vesiliikenteen väylämaksu ja raideliikenteen ratamaksu}

Valtion veronluonteisten maksujen joukossa on väylämaksu. Sitä suoritetaan valtiolle Suomen vesialueella kauppamerenkulkua harjoittavasta aluksesta. Ennen 2000-lukua voimassa oli vuonna 1980 säädetty väylämaksulaki, jolla oli kumottu majakkamaksun suorittamisesta vuonna 1921 annettu laki ja jäämaksun suorittamisesta talvisaikaisesta kauppamerenkulusta vuonna 1920 annettu laki sekä vuonna 1963 
annettu asetus merenkulkumaksujen perimisestä suojakansialuksista eräissä tapauksissa.

Valtion rataverkon käyttämisestä on Suomessa peritty ratamaksua vuodesta 1990 lähtien, siis jo ennen kuin Valtionrautatiet vuonna 1995 yhtiöitettiin ja radanpito siirrettiin rautatieviranomaiseksi perustetulle Ratahallintokeskukselle.

\subsubsection{Ajoneuvovero}

Ajoneuvojen käyttövaiheen verotus alkoi tulliverotuksena. Se kohdistui erityisesti auton voimanlähteenä käytettyyn polttoaineeseen. Kiinteätyyppinen, hallintaperusteinen ajoneuvon käyttövaiheeseen kohdistuva verotus aloitettiin Suomessa vuonna 1922 leimaverolain nojalla kannettuna verona. Vero säädettiin progressiiviseksi moottoritehon suhteen. Tätä perusteltiin sillä, että tiestöä eniten vahingoittavissa suurissa autoissa ja arvokkaammissa autoissa oli yleensä voimakkaammat moottorit. Auton käyttämän polttoaineen laadulla ei ollut merkitystä veromäärään.

Verotuksen uudistaminen ja saattaminen erillisen moottoriajoneuvoverolain perusteella määräytyväksi tuli 1920-luvun lopulla ajankohtaiseksi muun muassa siksi, että silloisen veron tuotto oli jäänyt vähäiseksi. Uudistuksessa korostettiin, että veron oli perustuttava ylellisyysnäkökohdan sijasta aikaisempaa enemmän tietaloudellisille näkökohdille. Todettiin, että tiestön kulumiseen vaikutti myös ajoneuvon nopeus. Kun Suomen teillä ei kuitenkaan yleensä voitu ajaa suuremmalla nopeudella kuin sellaisella, jonka melkein kaikki henkilöautot pystyivät saavuttamaan, otettiin moottorin teho huomioon aikaisempaa rajoitetummin. Koska tiestön kulumiseen vaikutti myös renkaiden tyyppi, veroa määrättiin kannettavaksi korotettuna sellaisista ajoneuvoista, joiden pyörissä ei ollut kumisia ilmarenkaita. Vero oli suurempi myös perävaunullisille ajoneuvoille. Sivuvaunullisen moottoripyörän vero oli sivuvaunuttoman veroa korkeampi.

Veron tuotto olisi hallituksen esityksen mukaan ollut käytettävä yleisten teiden parantamiseen ja kunnossapitoon. Tämä velvoite kuitenkin poistettiin lopullisesta laista, koska katsottiin, että eduskunnan tuli saada vapaasti päättää tämänkin veron tuotosta. 
Moottoriajoneuvoverotuksessa siirryttiin uuteen vaiheeseen 1930luvun lopulla. Uudistus tuli ajankohtaiseksi erityisesti sen takia, että korkean tullin alaista bensiiniä käyttävien ajoneuvojen rinnalle olivat yleistyneet ajoneuvot, joiden polttoaineena käytettiin alhaisen tulliverotuksen piirissä olevaa dieselöljyä. Ruotsin esikuvan mukaisesti säädettiin vuodesta 1939 alkaen kannettavaksi ajettujen kilometrien mukaan määräytyvää lisäveroa ajoneuvoista, joita käytettiin muulla voimalla tai polttoaineella kuin bensiinillä. Suuremman oikeudenmukaisuuden ja tasaisemman verotuksen saavuttamiseksi moottoriajoneuvovero laskettiin ajoneuvon oman painon tai kokonaispainon perusteella.

Moottoriajoneuvoverotus uudistettiin vuodesta 1948 alkaen. Lisäveron (joka vastasi nykyistä käyttövoimaveroa) määräytymisperusteissa luovuttiin käyttämästä ajettuja kilometrejä. Veron periminen ajettujen kilometrien mukaisesti olisi edellyttänyt täysin varmaa matkamittaria sekä ehdottoman oikein pidettyä ajopäiväkirjaa. Niitten ei katsottu voivan toteutua, ja veron määrääminen olikin jäänyt käytännössä usein harkinnan varaan. Veron määräämisen perusteeksi otettiin keskimääräiset ajomatkat eri ajoneuvotyypeille.

Vuoden 1965 alusta toteutettiin erittäin merkittävä rakenteellinen uudistus, kun moottoriajoneuvovero poistettiin bensiinikäyttöisiltä ajoneuvoilta ja vastaavasti bensiinin valmisteveroa korotettiin. Tämän jälkeen varsinainen ajoneuvovero (joka vastasi nykyistä käyttövoimaveroa) tuli kannettavaksi vain muilta kuin bensiinikäyttöisiltä ajoneuvoilta, siis lähinnä dieselajoneuvoilta. Polttoöljyn käytön seurauksena oli lisävero (joka vastasi nykyistä polttoainemaksua).

Järjestelmä säilyi tämän jälkeen pitkään rakenteellisesti lähes muuttumattomana. Vuosi 1976 oli kuitenkin mielenkiintoinen. Silloin Suomessa rekisterissä olleista liikenteeseen käytetystä henkilöautosta kannettiin erityistä käyttömaksua. Maksun säätämisen perusteet olivat valtiontaloudellisia. Käyttömaksu (50, 100, 150 tai $250 \mathrm{mk}$ ) märäytyi auton kokonaispainon perusteella. Maksu suoritettiin siten, että maksuvelvollinen lunasti postista tai tullista autoon kiinnitettäväksi maksun määrää vastaavan käyttömaksumerkin. Tästä olivat vapautettuja valtion omistamat autot, ammattimaisessa liikenteessä käytettävät autot sekä autot, joista oli saatu invalidipalautusta. Käyttömaksu tuotti 113 miljoonaa markkaa, kun samana vuonna esimer- 
kiksi moottoriajoneuvovero tuotti 97 miljoonaa markkaa. Vuoden 1976 käyttömaksu oli tarkoitettu väliaikaiseksi yhtä vuotta koskevaksi fiskaaliseksi järjestelyksi, eikä se saanutkaan pitkään aikaan jatkoa.

Antaessaan keväällä 1993 auto- ja moottoripyöräverolain muutosesityksen hallitus sisällytti valtioneuvoston pöytäkirjaan lausuman, jonka mukaan tuosta lainmuutoksesta johtuva autoveron tuoton alentuminen oli korvattava ottamalla käyttöön kaikkia autoja koskeva vuotuinen vero. Autoveroa alennettiin noin viidennes. Verotulojen vähentymisen korvaamiseksi säädettiin laki eräistä ajoneuvoista suoritettavasta ajoneuvoverosta. Tuon lain mukaan ajoneuvovero kannettiin ajoneuvoon kiinnitettävällä veromerkillä. Veron suorittaminen järjestettiin siten, että ajoneuvon omistaja tai haltija oma-aloitteisesti hankki veromerkin ja kiinnitti sen ajoneuvonsa tuulilasiin. Vero muistutti vuoden 1976 käyttömaksua, mutta uusi vero oli tarkoitettu tieliikenteen verojärjestelmän pysyväksi ja olennaiseksi osaksi.

Kun laki säädettiin, keskeisenä lähtökohtana oli, että uudesta, suurta ajoneuvomäärää koskevasta veromuodosta oli tehtävä yksinkertainen. Vuonna 1994 veron määrä oli 500 tai 300 markkaa, ja vuodesta 1995 alkaen 700 markkaa (117 euroa) tai 500 markkaa (84 euroa). Korkeampaan veroluokkaan kuuluivat autot, jotka oli otettu käyttöön 1.1.1994 tai sen jälkeen. Se, että vero oli korkeampi uudemmista autoista, perustui siihen, että noista autoista oli kannettu alempaa autoveroa.

\subsubsection{Autokumirengasvero}

Ajoneuvon käyttövaiheen verona voitiin pitää 25 vuotta elänyttä autokumirenkaiden valmisteveroa. Hallitus antoi autokumirenkaiden valmisteveron käyttöönottoa koskeneen esityksen huhtikuussa 1938. Auton kumirenkaista oli aikaisemmin kannettu tullia, jonka tuotto oli ollut moottoriajoneuvoliikenteen merkittävästä kasvusta huolimatta laskusuunnassa. Tullitulojen lasku oli aiheutunut lisääntyneestä kotimaisten rengasvalmisteiden käytöstä. Kotimaista rengasteollisuutta oli osaltaan pyritty suojelemaan kantamalla ulkomaisista renkaista tuontitullia. Katsottiin, että kotimainen rengasteollisuus ei enää tarvinnut täydelliselle verovapaudelle perustuvaa suojaa, joten sen 
maksettavaksi katsottiin voitavan säätää kohtuullinen valmistevero. Veron säätäminen oli sopusoinnussa myös sen lähtökohdan kanssa, että moottoriajoneuvoliikenteen verotuksella pyrittiin kattamaan liikenteen yhteiskunnalle aiheuttamia kustannuksia. Tarvikkeiden ja polttoaineen kulutuksen katsottiin oikeudenmukaisimmin osoittavan ajoneuvon koon ja siitä aiheutuvan tien kulumisen.

Hallitus ehdotti ulkomailta maahan tuotavien kumirenkaiden tullin alentamista ja tätä alennusta vastaavan valmisteveron säätämistä sekä maahan tuotaville että kotimaassa valmistetuille autokumirenkaille. Laki hyväksyttiin, ja se tuli voimaan vuonna 1939. Veroa oli suoritettava pehmeästä kautsusta moottoriajoneuvoja varten valmistetuista päällys- ja sisäkumirenkaista tai niiden osista 8 markkaa kilolta.

Kun uusi moottoriajoneuvoverolaki vuonna 1964 säädettiin, autokumirenkaiden valmisteverosta annettu laki kumottiin. Autokumirengasveron tuotto oli markkamääräisesti suurimmillaan sen viimeisenä kantamisvuonna 1964 , jolloin se oli 0,1\% valtion verotuloista.

\subsubsection{Autovero}

Autojen hankintavaiheen verotus alkoi Suomessa tulliverotuksena. Ensimmäiset autot hankittiin Suomeen aivan 1900-luvun alussa, jolloin sovellettiin Venäjän vallan alaista tullitaksaa. Siinä ei määritelty autolle omaa tullinimikettä, vaan autoon sovellettiin nelipyöräisille vaunuille eli eräille ajokaluille määrättyä tullia. Itsenäisyyden ajan ensimmäinen tullitariffi tuli voimaan huhtikuussa 1919. Auton tulli määräytyi aluksi auton arvon perusteella, mutta vuonna 1939 se muutettiin ajoneuvon painoon perustuvaksi. Vuonna 1946 palattiin arvotulliin ja säädettiin painon perusteella laskettava vähimmäistulli.

Autojen ja moottoripyörien hankinnan eli maahantuonnin ja valmistamisen erityisvero, autovero, on Suomessa peräisin 1950-luvulta. Hallitus antoi vuonna 1951 esityksen autoverolaiksi. Esitystä perusteltiin sillä, että valtion menojen kasvu oli tehnyt välttämättömäksi valtion verotulojen lisäämisen. Koska verotuloja ei voitu riittävästi saada korottamalla välittömiä veroja, etsittiin välillisen verotuksen alalta uusia verotuskohteita. Hallituksen mielestä etusija oli annettava sellaisille verotusmuodoille, jotka kohdistuivat ylellisyyteen. 
Autokuljetus oli huomattavasti kasvanut, ja osaa siitä voitiin hallituksen mielestä pitää ylellisyysluonteisena. Kun se lisäksi tapahtui miltei yksinomaan ulkomaisen kaluston ja polttoaineen varassa ja kulutti niukkoja ulkomaisia valuuttoja, hallituksen mielestä oli tarkoituksenmukaista, että moottoriajoneuvojen hankkiminen olisi saatettu kohtuullisen, muun muassa ylellisyysnäkökohdat huomioon ottaen järjestetyn erityisveron alaiseksi. Hallitus esitti autoveroa, jota olisi ollut suoritettava kotimaassa valmistetuista ja maahan tuotavista moottoriajoneuvoista. Vero olisi kohdistunut muun muassa henkilöja pakettiautoihin ja niiden alustoihin, kuorma-, linja- ja seka-autojen alustoihin sekä moottoripyöriin.

Valtiovarainvaliokunta ei yhtynyt siihen, että ylellisyysnäkökohdilla voitaisiin puoltaa kyseistä veroa. Tuota perustetta ei valiokunnan mielestä voitu lainkaan esittää kuorma-, seka- eikä edes pakettiautojen osalta. Valiokunnan mielestä ylellisyysesineinä ei voitu pitää myöskään niitä henkilöautoja, joita käytettiin ammattimaiseen liikenteeseen tai joita käyttivät metsänhoitajat, maanmittarit, lääkärit, eläinlääkärit, maatalousjärjestöt, kunnalliset laitokset, liikennelaitokset, invalidit jne. Esitys oli valiokunnan mielestä perusteltavissa yksinomaan finanssisyillä.

Valiokunnassa harkittiin mahdollisuutta jättää autoverotuksen ulkopuolelle ammattimaiseen liikenteeseen käytettävät autot. Niin ikään pohdittiin verotuksen rajoittamista vain henkilöautoihin jopa yksinomaan ylellisyystarkoituksiin käytettäviin, tietyn painorajan ylittäviin loistoautoihin. Tämä olisi kuitenkin huomattavasti vähentänyt tavoiteltua verotulojen lisäystä. Lakimuutosten tekninen suorittaminen olisi myös vaatinut niin perusteellista ja asiantuntevaa valmistelua, ettei valiokunta siihen kyennyt. Valiokunta ehdottikin lakiehdotuksen hylkäämistä ja edellytti, että hallitus ottaa asian uudelleen harkittavakseen. Hallitus peruutti esityksensä mutta antoi vuonna 1953 uuden esityksen autoverolaiksi. Ehdotusta perusteltiin valtion menojen jatkuvalla kasvulla. Esitys oli samantapainen kuin vuonna 1951 annettu edeltäjänsä, mutta enää ei puhuttu ylellisyysnäkökohdista. Merkittävää oli myös, että nyt ehdotettiin kuorma-, seka- ja linja-autojen jättämistä veron ulkopuolelle.

Valtiovarainvaliokunta hyväksyi lakiehdotuksen edellyttäen kuitenkin, että niiden autojen osalta, joista perittäisiin autovero, poistettai- 
siin muutoin mahdollisesti perittävä hinnantasausmaksu. Valiokunta katsoi myös, etteivät paketti- ja henkilöpakettiauto olleet ylellisyysautoja, ja muutti esitystä siten, ettei autovero olisi koskenut niitä. Myöskään invalideilta ei valiokunnan mielestä ollut perittävä kyseistä veroa.

Hallitus peruutti esityksensä mutta antoi kohta uuden esityksen, joka oli pitkälti edellisen esityksen kaltainen. Valtiovarainvaliokunta hyväksyi nytkin lakiesityksen edellyttäen, että niiltä autoilta, joista perittäisiin autovero, poistettaisiin muutoin mahdollisesti perittävä hinnantasausmaksu. Suuren valiokunnan ehdotuksen mukaisesti lakiehdotus tuli kuitenkin hylätyksi.

Vuodesta 1953 hinnantasausrahastoon perittiin tasausmaksua myös henkilöautoista ja moottoripyöristä. Tasausmenettelyn tarkoituksena oli pitää ajoneuvojen myyntihinnat tasoltaan muuttumattomina riippumatta siitä, minkälaisin kauppamuodoin tai minkä hintaisin valuutoin tuontierät kulloinkin jouduttiin hankkimaan. Hinnantasauksella pyrittiin myös estämään muiden kuin moottoriajoneuvojen varsinaisten maahantuojien hankkimista tai vähän käytetyistä moottoriajoneuvoista perittyjen hintojen ja viranomaisten vahvistamien hintojen liian suurta eroa. Lisäksi tasausmaksuilla hankittiin hinnantasausrahastoon varoja hintapoliittisesti tärkeinä pidettyjen tarvikkeiden hintojen alentamiseksi. Käytännössä hinnantasausmaksut muodostuivat melkoisen veronluonteisiksi, ja järjestelmän lainsäädännöllistä pohjaa alettiin pitää yhä kyseenalaisempana.

Kun tuontikauppa edelleen vapautui ja valuuttakurssit muuttuivat, alettiin hinnantasausmenettelyä supistaa ja talouselämäämme kehittää kohti vakiintuneempia oloja. Valtiontalouden tila ei kuitenkaan mahdollistanut luopumista niistä tuloista, joita moottoriajoneuvoista perityt tasausmaksut olivat merkinneet. Henkilöautojen ja moottoripyörien tuontia oli rajoitettu, eikä myöskään pidetty tarkoituksenmukaisena antaa kyseisten ajoneuvojen vahvistettujen hintojen tason huomattavasti alentua, koska alennus olisi lisännyt keinottelumahdollisuuksia. Hallitus esittikin 22.11.1957 eduskunnalle, että tasausmaksumenettely korvattaisiin erityisellä auto- ja moottoripyöräverolla. Verovelvollisia olisivat maahantuojat ja valmistajat. Suomen solmimat kansainväliset sopimukset huomioon ottaen verorasituksen tuli olla ulkomailta tuoduille ja maassa valmistettaville ajoneuvoille sama. 
Niin ikään tuli verokanta - Suomen kauppasuhteisiin nähden ja kun kysymyksessä oli hallituksen mielestä yksi liikevaihtoverotuksen muoto - vahvistaa samaksi toisaalta autotyypeille ja toisaalta moottoripyörätyypeille. Autoille ehdotetun $40 \%: n$ ja moottoripyörille ehdotetun $30 \%$ :n verokannan mukainen tuotto vastasi hinnantasausmaksujärjestelmän autojen ja moottoripyörien osalta tuottamaa tuloa.

Valtiovarainvaliokunta puolsi lakiehdotuksen hyväksymistä tietyin muutoksin. Se piti hallituksen ehdottamia veroprosentteja tasausmaksuihin verrattuna aiheettoman korkeina ja ehdotti niiden alentamista autojen osalta 30 \%:iin ja moottoripyörien osalta $25 \%$ :iin. Valiokunnan mielestä myös oli kohtuullista, että ammattimaiseen liikenteeseen rekisteröidyt ajoneuvot saisivat vapautuksen autoveron koko määrästä.

Eduskunta hyväksyi lakiehdotuksen valtiovarainvaliokunnan esittämässä muodossa, kuitenkin siten, että tämä 1.1.1958 voimaan tullut laki oli vain yksivuotinen. Hyväksyessään lain eduskunta edellytti, että vero on vain tilapäinen ja valtion senhetkisestä poikkeuksellisen kireästä rahatilanteesta johtuva, ja että verosta pyritään luopumaan etenkin halvemman hintaluokan ajoneuvojen osalta heti kun valtiontalous antaa siihen mahdollisuuden.

Hallitus antoi lokakuussa 1958 esityksen, jolla lain voimassaoloaikaa ehdotettiin pidennettäväksi vuoden 1959 loppuun. Samalla veron märä sekä autoista että moottoripyöristä ehdotettiin alennettavaksi $20 \%$ :iin ajoneuvon verotusarvosta. Valtiovarainvaliokunta teki esitykseen pari muutosta: se ehdotti moottoripyöräveron alentamista 15 \%:iin ja ehdotti lisäksi, että sama verovapaus, joka oli moottoripolkupyörillä, ulotettaisiin koskemaan myös kevyitä moottoripyöriä. Tätä perusteltiin sillä, että kevyet moottoripyörät olivat rinnastettavissa moottoripolkupyöriin ja että ne olivat liikenneturvallisuuden kannalta näitä varmempia. Liikenneturvallisuuteen osattiin siis vedota jo näin varhain. Laki hyväksyttiin valtiovarainvaliokunnan esittämässä muodossa.

Hallitus antoi syyskuussa 1959 esityksen lain voimassaoloajan jatkamisesta vuodeksi 1960. Valtiovarainvaliokunta ehdotti eräitä muutoksia. Lakialoitteen pohjalta valiokunta samalla katsoi, että kouluautot oli vapautettava autoverosta samoin edellytyksin kuin ammattimaiseen liikenteeseen käytetyt autot. Laki hyväksyttiin val- 
tiovarainvaliokunnan esittämässä muodossa. Myöhemmin lain voimassaoloaikaa jatkettiin vielä vuoden 1961 loppuun.

Auto- ja moottoripyöräverosta luopumista ei pidetty mahdollisena. Koska lakia oli useasti muutettu, katsottiin tarpeelliseksi korvata se kokonaan uudella lailla. Hallitus antoi tätä tarkoittavan esityksen syyskuussa 1961. Samalla ehdotettiin veron kiertämisen estämiseksi lakia täydennettäväksi siten, että vero oli suoritettava myös ajoneuvon henkilöautoksi muuttamisesta ja että verovelvollinen oli tällöin se, joka rekisteröi muutetun ajoneuvon henkilöautona. Koska autoveroa ei kannettu kuorma- ja pakettiautoista, ehdotettiin tavarankuljetukseen tarkoitetut kolmipyöräiset moottoripyörätkin vapautettavaksi verosta. Niin ikään ehdotettiin maastoautot, joita varsinkin metsätaloudessa käytettiin työautoina, nimenomaan säädettäväksi verottomiksi.

Muutoin lakiehdotus oli varsin samanlainen kuin vuonna 1957 säädetty laki siihen tehtyine muutoksineen. Valtiovarainvaliokunta puolsi hallituksen esityksen hyväksymistä pienin korjauksin, ja laki henkilöautoista ja moottoripyöristä suoritettavasta verosta hyväksyttiin sen mukaisena. Laki oli tarkoitettu olemaan voimassa vuoden 1962 loppuun, mutta se korvattiin jo vuoden 1962 kesällä uudella, olennaisesti ankarammalla lailla.

Uusi laki tuli voimaan 15.7.1962. Keskeistä siinä oli autoveron olennainen korottaminen ja veron säätäminen progressiiviseksi. Korotuksella pyrittiin saamaan ostopaine autojen tuontisäännöstelyn jälkeen jakaantumaan usean vuoden osalle. Uusi laki saatiin säädetyksi vain yksivuotisena, ja sen mukainen autovero oli 40-90 \% auton verotusarvosta siten, että vero oli suurin kalleimmissa autoissa. Tässä oli hallituksen esityksen perustelujen mukaan otettu huomioon kauppapoliittiset näkökohdat ja bilateraalisen kaupan edut.

Nyt lakiin tuli sellainen merkittävä uutuus, että pakettiautoistakin oli maahan tuotaessa suoritettava autovero, mutta vero palautettiin, jos auto rekisteröitiin pakettiautoksi ja sitä pääasiallisesti sellaisena käytettiin. Tässä omaksuttiin samantapainen palautusmenettely kuin ammattimaiseen liikenteeseen käytettyjen autojen osalta oli käytössä.

Vuoden 1962 lain voimassaoloaikaa jatkettiin vuoden 1963 loppuun. Syyskuussa 1963 hallitus antoi esityksen lain voimassaolo- 
ajan pidentämisestä vuoden 1964 loppuun. Autoveroa ehdotettiin 35-80 \%:ksi verotusarvosta. Samalla lakia ehdotettiin täsmennettäväksi niiden varusteiden osalta, joiden arvo luettiin ajoneuvon verotusarvoon. Lakia ehdotettiin tarkistettavaksi myös siten, että autoverosta vapaaksi suoraan lain perusteella säädettäisiin paloauto, sairasauto ja ruumisauto sekä kuorma-auto, samoin sellainen pakettiauto, jota sen rakenteeseen ja varusteisiin katsoen oli pidettävä ensisijaisesti vain tavaran kuljetukseen tarkoitettuna ja jonka kokonaispaino oli vähintään $1700 \mathrm{~kg}$. Invalidien osalta lakia ehdotettiin muutettavaksi siten, että liikuntavammaisten invaliditeettiprosentti alennettaisiin $80 \%$ :ksi ja asetettaisiin vaatimus invalidiauton kohtuuhintaisuudesta. Valtiovarainvaliokunta puolsi lakiehdotusta eräin vähäisin tarkistuksin. Laki hyväksyttiin valtiovarainvaliokunnan esittämässä muodossa.

Hallitus antoi syyskuussa 1964 esityksen, jolla lain voimassaoloaikaa ehdotettiin pidennettäväksi vuoden 1965 loppuun. Samalla ehdotettiin säännöstä, jonka mukaan ajoneuvon luvattoman käytön estävää laitetta ei luettaisi verotusarvoon. Valtiovarainvaliokunta puolsi esityksen hyväksymistä muutoin paitsi että veron kuoleutumisaika ehdotettiin lyhennettäväksi neljästä vuodesta kolmeen vuoteen. Laki hyväksyttiin valtiovarainvaliokunnan esittämässä muodossa.

Vuoden 1965 puolivälissä autoveroa jälleen korotettiin. Hallitus ehdotti maksutaseen tasapainottamiseksi autoveron korottamista 35-95 \%:ksi auton verotusarvosta. Valtiovarainvaliokunnan mietinnössä puollettiin hallituksen esitystä. Mietintöön liittyi kuitenkin kokoomuksen edustajien vastalause. Sen mukaan veron porrastettu järjestelmä oli kauppapoliittisesti epäoikeudenmukainen ja aiheutti käytännössä epäasiallista automallien muuntamista. Vastalauseessa ehdotettiin autovero märitettäväksi siten, että se olisi verotusarvon määrä vähennettynä 1500 markalla. Suuressa valiokunnassa esitys muuttuikin tämän mukaiseksi. Tasoltaan tämän uuden laskutavan mukainen vero vastasi suunnilleen hallituksen esittämää, mutta siinä ei ollut samanlaisia hyppäyksiä.

Uuden vaiheen autoverotuksemme historiassa voidaan katsoa alkaneen vuoden 1966 puolivälissä. Niin olennaisesta verotuksen ankaroitumisesta oli kysymys, kun autoveroa tuolloin maksutaseongelmien vuoksi korotettiin. Nyt autoveroa oli suoritettava auton verotusarvon 
määrä korotettuna $50 \%$ :lla ja vähennettynä 2250 markalla. Lain voimassaoloaikaa jatkettiin vuoden 1966 lopussa. Vuoden 1967 alkupuoliskolla veroa korotettiin vielä jonkin verran, millä pyrittiin kompensoimaan EFTA-tullien alennuksista aiheutuvaa verojen alentumista.

Hallitus antoi syyskuussa 1967 esityksen, jossa jälleen esitettiin autoverotuksen tiukentamista. Nyt ehdotettiin erityisesti taksien, kouluautojen ja pakettiautojen veronpalautusoikeuden poistamista. Hallituksen käsityksen mukaan ne ammatin- ja liikkeenharjoittajat, jotka olivat oikeutettuja veronpalautukseen, olivat sellaisia ammatin- ja liikkeenharjoittajia edullisemmassa asemassa, joille auton käyttäminen samalla tavoin oli välttämätöntä mutta jotka eivät olleet oikeutettuja veronpalautukseen. Lisäksi viitattiin autoveronpalautusten valtion tuloja vähentävään vaikutukseen.

Hallitus kuitenkin peruutti esityksensä 3.11.1967, pian suuren devalvaation jälkeen, ja antoi samalla esityksen kokonaan uudeksi laiksi auto- ja moottoripyöräverosta. Nyt saatiin vihdoin säädetyksi pysyvä autoverolaki; tosin myöhemmin muutamia kertoja jouduttiin turvautumaan yksivuotisiin lainmuutoksiin. Uusi laki tuli voimaan 15.11.1967. Autoveron määrää alennettiin; tarkoituksena oli lieventää devalvaatiosta johtuvia autojen hinnankorotuksia. Autoveroksi säädettiin auton verotusarvo korotettuna $40 \%$ :lla ja vähennettynä 2500 mk:lla. Kun oli odotettavissa, että maahan ruvettaisiin tuomaan runsaasti käytettyjä autoja, lakiin otettiin säännös, jonka mukaan käytetyn auton vero oli $90 \%$ vastaavan uuden auton verosta.

Vuonna 1969 säädettiin Suomessa valmistetun auton ja moottoripyörän verotusarvoksi ajoneuvon valmistuskustannusten perusteella määriteltävä ajoneuvon hinta valmistuspaikalla. Asia alkoi tulla entistä tärkeämmäksi, kun henkilöautojen massatuotanto Suomessakin alkoi.

Autoverotuksessa alettiin 1970-luvun alussa kiinnittää entistä enemmän huomiota liikenneturvallisuuteen. Vuodenvaihteessa 1970-1971 säädettiin turvavyö sellaiseksi varusteeksi, jonka arvoa ei luettu auton verotusarvoon.

Vuonna 1971 autoverotukseemme tuli suuri muutos, kun pakettiautojen verovapaus rajoitettiin ajoneuvoihin, joiden tavaratila täytti tietyt vähimmäismitat. Näin verovapaus jäi koskemaan enää yleensä 
vain melko kookkaita laatikkomallisia pakettiautoja. Lainmuutoksen seurauksena uusien pakettiautojen tuonti laski erittäin voimakkaasti.

Vuoden 1973 lopulla moottoripyörien veroa korotettiin olennaisesti etenkin suurten pyörien osalta. Tätä perusteltiin ennen kaikkea liikenneturvallisuusnäkökohdilla.

Vuodenvaihteessa 1973-1974 autoveroa korotettiin jonkin verran. Korotuksella pyrittiin kompensoimaan vapaakauppasopimusten seurauksena tapahtuneita autojen tullinalennuksia.

Vuoden 1973 lopun öljykriisi nosti energian hintoja olennaisesti. Kustannusten vaikutusta ammattiautoiluun lievennettiin vuoden 1974 alussa lainmuutoksella, jonka mukaan ammattimaisessa liikenteessä käytettävän auton autovero voitiin palauttaa kokonaankin tiettyyn enimmäismäärään saakka. Muutosta perusteltiin muun muassa sillä, että se edesauttoi siirtymistä kestävämpään ja kulutukseltaan taloudellisempaan ajokalustoon. Suuntauksen tueksi otettiin myös energiataloudelliset ja ympäristönsuojelulliset seikat.

Maahantuotujen uusien autojen lukumäärä nousi vuonna 1975 syksyyn mennessä erittäin voimakkaasti, ja valtio ryhtyi taas tiukkoihin tuonninrajoitustoimiin maksutaseen turvaamiseksi. Maan ulkomaankaupan ja taloudellisen kasvun turvaamisesta annetun lain nojalla annetuilla asetuksilla muun muassa autojen ja moottoripyörien maahantuonnista määrättiin suoritettavaksi erityismaksua. Maksu oli suoritettava sellaisista ajoneuvoista, joista oli maksettava auto- ja moottoripyöräveroa. Maksu oli 18.10 .1975 alkaen $50 \%$ autoverolain mukaisesta auto- ja moottoripyöräverosta. Myöhemmin samana vuonna annetuilla asetuksilla maksu alennettiin $30 \%$ :ksi, sitten $20 \%$ :ksi ja lopulta $10 \%$ :ksi, ja vuoden 1976 alusta maksu kumottiin kokonaan. Vuonna 1976 auto- ja moottoripyöräveroa puolestaan kannettiin korotettuna.

Vuoden 1977 alusta autoverotuksessa palattiin "normaalille" tasolle. Samalla moottoripyörien verotusta melkoisesti lievennettiin siitä, mikä se oli ollut muutaman edellisvuoden. Vuoden 1978 alusta voimaan tulleella lainmuutoksella liikenneturvallisuudelle annettiin aikaisempaa selvästi suurempi merkitys säätämällä, että tiettyjä varusteita ei luettu auton verotusarvoon. Säännöksen muotoilulla pyrittiin myös suosimaan suomalaista tuotantoa. 
1980-luvun alkupuolta voidaan luonnehtia autoverotuksen hienosäätelyn ajaksi. Tehtiin esimerkiksi lainmuutoksia, joilla pyrittiin estämään "yli-ikäisten" uusien ajoneuvojen maahantuontia sekä kolarivaurioituneiden ajoneuvojen ja niiden osien tuontia. Samaan linjaan kuuluu myös lainmuutos, jolla maastohenkilöautot tulivat verollisiksi. Niiden vero kuitenkin säädettiin muiden henkilöautojen veroa alemmaksi. Autoverotuksen lainmuutokset 1980-luvun puolivälissä ja sen jälkeen koskivat muun muassa verotuksen yksinkertaistamista ja selkeyttämistä.

Vuoden 1988 lopun merkittävin uutuus oli ympäristöpoliittinen: vähäpäästöisten bensiinihenkilöautojen verotusarvosta tehtävä katalysaattorivähennys.

Henkilöautojen kuluttajahintojen alentamiseksi sekä tieliikenteen verotuksen painopisteen siirtämiseksi kohti käyttövaiheen verotusta sekä autoalan työllisyyden tukemiseksi autoveroprosenttia alennettiin 1990-luvun alussa. Muutokseen liittyi uuden ajoneuvoveron eli niin sanotun auton käyttömaksun käyttöönotto. Vaikka autoveroa 1990-luvun alussa yleensä alennettiin, pakettiautojen kohdalla suunta oli päinvastainen.

\subsubsection{Liikevaihtovero}

Yleisen kulutusverotuksen eli liikevaihtoverotuksen katsotaan alkaneen, kun I maailmansota finanssitarpeineen johti ensin Saksassa (1916) ja pian monissa muissakin maissa tämän verotusmuodon käyttöön ottamiseen.

Suomessa liikevaihtoverotus otettiin käyttöön vuonna 1941, kun ulkomaankauppa oli sodan takia tyrehtynyt ja valtiolle tärkeän tulonlähteen muodostaneet tullitulot olivat romahtaneet. Ensimmäinen liikevaihtoverolakimme perustui yhdistettyyn tuotanto- ja vähittäismyyntijärjestelmään. Sosiaalisista ja veroteknisistä syistä verosta vapautettiin muun muassa tärkeimmät peruselintarvikkeet sekä tupakka ja alkoholijuomat, vesi, tietyt energiatuotteet ja väkilannoitteet. Suomen toinen liikevaihtoverolaki tuli voimaan jo vuoden 1942 alussa ja oli voimassa vuoden 1950 loppuun. Tämäkin laki perustui yhdistettyyn tuotanto- ja vähittäismyyntijärjestelmään. Verottomien 
tavaroiden määrä kasvoi vähitellen suureksi ja tuotti lähinnä vähittäiskauppiaille suuria erotteluvaikeuksia. Vähittäiskaupassa oli lisäksi runsaasti sellaisia yrityksiä, joiden edellytykset hoitaa liikevaihtoveroasioita olivat rajalliset. Verovelvollisten lukumäärä lisääntyi huomattavasti, mikä vaikeutti verotuksen valvontaa.

Kolmas liikevaihtoverolaki tuli voimaan vuoden 1951 alussa ja oli voimassa vuoden 1963 loppuun. Kahden vaiheen verotuksesta siirryttiin yhden vaiheen verotukseen ottamalla käyttöön tuotantoverojärjestelmä. Verovelvollisia olivat tuotannolliset yritykset eli teolliset ja työliikkeet sekä lisäksi anniskelu- ja tanssiravintolaliikkeiden harjoittajat. Verovelvollisten lukumäärä aleni noin kolmannekseen edelliseen järjestelmään verrattuna. Verottomia olivat muun muassa elintarvikkeet ja monet niin sanotut välttämättömyyshyödykkeet, apteekkitavarat, vesi, tietyt energiahyödykkeet, rehut, lannoitteet, maatalouskoneet, sanoma- ja aikakauslehdet sekä varsinaiseen kirjallisuuteen kuuluvat kirjat. Ylellisyysverotukseen viittaavia piirteitä näkyi suhtautumisessa asusteisiin, kun verottomiksi säädettiin

- työrukkaset

- jalkineet, naisten kulta-, hopea-, brokaadi-, opaali-, silkki-, satiini-, pronssi-, kalannahka- ja matelijannahkaisia kenkiä sekä miesten kiiltonahkakenkiä lukuun ottamatta

- seuraavat tekstiiliaineet ja -tavarat, sikäli kuin ne eivät ole luonnonsilkkiä tai kullankehrääjätavaraa: langat, kankaat metritavarana ja huonekaluihin kiinnitettyinä, karvalanka- ja räsymatot, pitovaatteet ja asusteet, vuodevaatteet, pyyheliinat ja pyyhkeet sekä verhot ja pöytäliinat

- hattupalmikko, hatunteelmät, hatut, lakit ja muut päähineet, niihin luettuna turkishatut, jotka on valmistettu verovapaasta turkislammasnahasta

- turkislammasnahka, lukuun ottamatta krimi-, astrakaani-, persiaani-, puolipersiaani- ja tiibettinahkaa, ja siitä valmistetut turkistuotteet

- nahka-, kumi- ja muovivaatteet. 
Tuotantoverojärjestelmä osoittautui epäneutraaliksi ja hallinnollisesti raskaaksi. Raja teollisen liikkeen, työliikkeen ja ei-verovelvollisen käsityöläisen välillä muodostui epäselväksi ja usein mielivaltaiseksi, mikä vinoutti yritysten välistä kilpailutilannetta. Verokannan kapeudesta aiheutuva veron korkeus johti verottomien tavaroiden määrän huomattavaan kasvuun, eikä jaossa verollisen ja verottoman tavaran välillä ollut useinkaan löydettävissä johdonmukaisuutta. Suurimmat vaikeudet aiheutuivat siitä, että tukku- ja vähittäiskauppaporras olivat verotuksen ulkopuolella; tavaran koko vähittäismyyntihinta ei joutunut verotuksen kohteeksi. Tämä johti veron tuottoa pienentäviin siirtohintajärjestelyihin ja lopulta siihen, että koko tuotantoverojärjestelmästä oli luovuttava.

Neljäs liikevaihtoverolaki tuli voimaan vuoden 1964 alussa. Siirryttiin järjestelmään, jossa vero kannettiin taloudellisen vaihdannan kaikissa vaiheissa ja jokainen vaihdannan porras suoritti veroa saman prosentin mukaan tavaran myynti- ja ostohinnan erotuksesta eli tuotteelle yrityksessä muodostuneesta arvonlisästä. Vero kohdistui siten tuotteen koko kuluttajahintaan. Laki perustui keskeisiltä osiltaan arvonlisäveron ideaan ja oli siinä maailman ensimmäisiä.

Soveltamisalan ulkopuolelle jäi lukuisia keskeisiä palveluja ( $\mathrm{mm}$. kuljetus-, majoitus-, suunnittelu-, konsultointi- ja mainostoimistopalvelut). Myös varsinainen rakennustyö pidettiin edelleen verotuksen ulkopuolella. Verovelvollisten piiri pyrittiin saamaan laajaksi; verovelvolliseksi säädettiin lähtökohtaisesti jokainen, joka harjoitti tavaran myyntiä liiketoiminnan muodossa. Alkutuotannon harjoittajat eivät olleet verovelvollisia.

Vero kohdistui periaatteessa saman suuruisena kaikkien tavaroiden kuluttajahintoihin. Sosiaalisista, talouspoliittisista ja verotusteknisistä syistä tiettyjen tavaroiden kuluttajahintaa rasittava vero kuitenkin poistettiin joko kokonaan (verottomat tavarat) tai alkutuottajan myyntihinnan osalta (ns. osittaisverolliset tavarat). Kaikkien verollisten tavaroiden myynti oli jokaisessa vaihdannan portaassa saman veroprosentin suuruinen. Verokanta oli aluksi $10 \%$, sittemmin $11 \%$, $14 \%, 16 \%, 16,5 \%, 17 \%$ ja lopulta $17,5 \%$ laskettuna hinnasta, johon vero sisältyi. 
Erityisen ankaraa liikevaihtoverotus oli 6.6.-31.12.1971 välisenä aikana. ${ }^{3}$ Silloin tuonnin kasvun hillitsemiseksi ja kauppataseen vajauksen pienentämiseksi perittiin monista kestokulutustavaroista normaalin $11 \%$ :n liikevaihtoveron lisäksi liikevaihtoveron lisäveroa, jonka suuruus oli $15 \%$ tavaran arvosta (laki 428/1971, HE 64/1971). Lisäveron piirissä olivat muun muassa autoveronalaiset autot ja moottoripyörät, alle $1600 \mathrm{~kg}: n$ painoiset moottorilentokoneet, lasikuitu-, muovi- alumiiniveneet soutuveneitä lukuun ottamatta, jääkaapit, pölynimurit, radiot, televisiot, kamerat, kellot ja korut. ${ }^{4}$ Liikevaihtoveron lisäveroa ei suoritettu käytettyjen tavaroiden myynnistä.

Suomen liikevaihtoverotus uudistettiin 1.10.1991 voimaan tulleella liikevaihtoverolailla, joka oli järjestyksessä viides. Tällä selkeytettiin järjestelmää ja muutettiin se lainsäädäntöteknisesti vastaamaan ajan vaatimuksia sekä kansainvälistä käytäntöä ja kilpailijamaiden verotusta. Uudessa laissa vähennysoikeuksia laajennettiin mutta merkittäviä rajoituksia kuitenkin jäi. Verokannaksi säädettiin $22 \%$ verottomasta hinnasta, mikä oli noin 18 verollisesta hinnasta.

Hanke siirtyä laajapohjaiseen arvonlisäverotukseen oli pitkään vireillä. Se konkretisoitui, kun asia vuonna 1991 otettiin hallitusohjelmaan. Hallitus antoi kesäkuussa 1993 eduskunnalle esityksen arvonlisäverolaiksi, ja arvonlisäverolaki tuli voimaan 1.6.1994. Lakia muutettiin perusteellisesti vuoden 1995 alusta, kun Suomesta tuli EU:n jäsen ja osa sisämarkkina-aluetta.

\subsubsection{Vakuutusmaksuvero}

Vakuutuspalvelut ovat olleet ja ovat yhä yleisen kulutusverotuksen ulkopuolella. Eräistä vakuutusmaksuista on kuitenkin kannettu vuoden 1967 alusta Suomessa vakuutusmaksuveroa. Erityisen kulutusveron kohteena monet vakuutuspalvelut ovat useissa muissakin Euroopan maissa.

3 Veron väliaikaisuudella pyrittiin siihen, että kysyntäpaine saataisiin ajoittumaan vaihtotasekehityksen kannalta tarkoituksenmukaisesti. Veron perustavoite ei siis ollut fiskaalinen vaan subdannepoliittinen.

4 Valtiovarainvaliokunta ei pitänyt tarkoituksenmukaisena puuveneiden, moottoripolkupyörien, liesien, uunien ja keittiöjakkaroiden eikä myöskään pilliurkujen ja turkisnahkavaatteiden saattamista lisäveron alaisiksi. 
Esittäessään vuonna 1966 vakuutusmaksuveroa hallitus viittasi tarpeeseen lisätä verotuloja valtion tulo- ja menoarvion tasapainottamiseksi. Tämä haluttiin toteuttaa tavalla, joka mahdollisimman vähän häiritsisi maamme taloudellista kasvua. Hallituksen mielestä veron kansantaloudelliset haitat olivat pienet ja tuotto verraten suuri. Vakuutusmaksuvero onkin poikkeuksellisen selvästi fiskaalinen vero. Sen tuotto on merkittävä ottaen huomioon veropohjan kapeus. Esimerkiksi vuonna 2017 veron arvioidaan tuottavan yli 800 miljoonaa euroa, siis saman verran kuin vuotuinen ajoneuvovero ja paljon enemmän kuin esimerkiksi perintö- ja lahjavero.

Vakuutusmaksun verokanta on seurannut liikevaihtoveron/arvonlisäveron verokantaa ja on nykyisin $24 \%$. Muuten vero kuitenkin olennaisesti poikkeaa yleisestä kulutusverosta. Vakuutusmaksuverotuksessa ei ole esimerkiksi ostovähennysjärjestelmää, mutta ketjuuntumisen välttämiseksi jälleenvakuutus on verotonta.

\subsubsection{Meriliikenteen matkustajavero}

Maassamme on 1960-luvulta lähtien esitetty, että valtion verotuloja tulisi lisätä ulkomaanmatkoja verottamalla. Helmikuun alussa 1968 tuli voimaan laki matkustajaverosta. Sen mukaan jokainen Suomesta ulkomaille kauppa-aluksella meriteitse matkustava Suomessa asuva henkilö oli velvollinen suorittamaan maasta lähtiessään valtiolle enintään 90 meripeninkulman matkasta 5 markan ja yli 90 meripeninkulman matkasta 10 markan määräisen matkustajaveron. Tietyt ryhmät, muun muassa alle 12-vuotiaat, saivat matkustaa ilman matkustajaveron maksamisvelvollisuutta. Hallitus perusteli matkustajaveroa muun muassa sillä, että maamme maksutase matkustajaliikenteen osalta oli ollut jatkuvasti negatiivinen ja että oli ilmeistä, että matkustajaliikenteen valuuttatulojen ja -menojen suhde tulisi säilymään Suomelle epäedullisena, joten valuutan maastavientiä oli syytä pyrkiä rajoittamaan verotuksella.

Laki matkustajaverosta kumottiin jo vuoden 1970 lopussa. Hallitus perusteli lain kumoamista muun muassa sillä, että matkustajaveron tuotto oli sekä vuonna 1968 että 1969 jäänyt arvioitua pienemmäksi, ja sillä, että veron kannosta syntyi niin suuria kustannuksia, että kyseistä veroa ei enää katsottu tarkoituksenmukaiseksi. 
Maamme matkustustase oli vuonna 1990 vahvasti alijäämäinen. Se muodosti neljänneksen vaihtotaseen alijäämästä. Hallitus arvioi, että matkustajaveron vaikutuksesta Suomen matkustustase voisi tasapainottua. Laman aiheuttaman verotulojen vähentymisen takia oli löydettävä uusia verotuloja. Sopivana keinona hallitus piti kohtuullisen suuruisen matkustajaveron sääämistä. Matkustajaverolaki tuli voimaan 15.1.1992, ja se oli voimassa vuoden 1992 loppuun.

Matkatoimistoliikkeen harjoittaja, liikenteen harjoittaja ja liikenteen harjoittajan asiamies joutuivat matkustajaverolain nojalla suorittamaan veroa jokaisesta matkustajasta, jolle verovelvollinen oli myynyt tai luovuttanut Suomesta ulkomaille lähtevään laivamatkaan oikeuttavan matkalipun. Vero oli porrastettu matkan pituuden mukaan. Se oli 100 markkaa matkustajasta, jonka merimatka oli yli 200 meripeninkulmaa; 60 markkaa matkustajasta, jonka matka oli yli 100 meripeninkulmaa mutta enintään 200 meripeninkulmaa; ja 30 markkaa laivaristeilyn matkustajasta sekä matkustajasta, jonka merimatka oli enintään 100 meripeninkulmaa. Veroa ei ollut suoritettava alle 12 -vuotiaasta.

Matkustajaverolain voimassaoloaikaa ei jatkettu vuoden 1992 jälkeen. Hallitus perusteli tätä sillä, että laivaliikenne ei maamme kannalta ollut alijäämäinen ja siten veron periminen ei ensisijaisen keräämistarkoituksensa eli vaihtotaseen vaikuttamistarkoituksen vuoksi ollut perusteltua.

\subsubsection{Ilmaliikenteen matkustaja- ja tilauslentoverot}

Vuonna 1978 hallitus antoi esityksen tilauslentoverolaista. Kotimaisten matkailijoiden matkat olivat alkaneet suuntautua massaturismin luonteisina ulkomaille, ja kotimaisen matkailuelinkeinon elvyttämiseksi esitettiin ulkomaille suuntautuvaan tilauslentoon osallistuvasta matkustajasta kannettavaksi 100 markan veroa. Tämän ajateltiin voivan välillisesti vaikuttaa suomalaismatkailijoiden päätöksentekoon siten, että ulkomaisen lomakohteen sijasta valittaisiin kotimainen kohde. Perusteena käytettiin myös sitä, että Tanskassa, Ruotsissa ja Norjassa olivat tulleet vuosina 1977 ja 1978 voimaan verosäädökset, joiden nojalla ulkomaille suuntautuvien tilauslentojen matkustajista 
oli maksettava valtiolle veroa. Muun muassa matkatoimistot ja Suomen Matkatoimistojen Liitto vastustivat voimakkaasti tämän niin sanotun charterveron käyttöönottoa. Suuri valiokunta esitti lakiesityksen hylkäämistä, ja hallitus peruutti esityksensä.

Chartervero otettiin 1980-luvulla esille useasti. Esimerkiksi valmisteverotusta tutkineessa valtiovarainministeriön työryhmässä vuonna 1980 keskusteltiin 100 markan charterverosta, ja veroa kaavailtiin yhdeksi osaksi ylellisyystuotteiden verotusta. Vuoden 1988 lisäbudjettiin kaavailtiin charterveron käyttöönottoa, mutta kyseistä veroa ei kuitenkaan 1980-luvun puolella säädetty.

Kuten edellä todettiin, Suomessa oli vuonna 1992 voimassa meriliikenteen matkustajaverolaki. Samanlainen vero koski silloin myös lentoliikennettä. Matkatoimistoliikkeen harjoittaja, liikenteen harjoittaja ja liikenteen harjoittajan asiamies joutuivat matkustajaverolain nojalla suorittamaan veroa jokaisesta matkustajasta, jolle verovelvollinen oli myynyt tai luovuttanut matkalipun, joka oikeutti Suomesta ulkomaille lähtevään tilauslentomatkaan. Veron määrä oli 200 markkaa tilauslennolla olevasta matkustajasta. Alle 12 -vuotiaasta veroa ei ollut suoritettava.

Matkustajaverolain voimassaoloaikaa ei jatkettu vuoden 1992 jälkeen vaan tilalle säädettiin vuodeksi 1993 tilauslentoverolaki, jonka voimassaoloaikaa myöhemmin jatkettiin vuoden 1994 loppuun. Tilauslentoveroa oli suoritettava Suomesta ulkomaille suuntautuvaan tilauslentomatkaan oikeuttavasta matkalipusta. Tilauslennoksi katsottiin tilauslentoverolain mukaan kaupallinen, matkustajia kuljettava lento, joka ei ollut säännöllistä liikennettä ja joka tapahtui vähintään 11 matkustajapaikkaa käsittävällä ilma-aluksella. Tuollainen määritelmä oli ennestään käytössä ilmailuhallinnossa.

Tilauslentoveron määrä oli 200 markkaa jokaisesta lentoon osallistuvasta, matkalippuun merkitystä matkustajasta. Veroa ei ollut suoritettava vuonna 1993 alkaneen matkan johdosta lapsesta, joka oli syntynyt vuonna 1982 tai myöhemmin, eikä vuonna 1994 alkaneen matkan johdosta lapsesta, joka oli syntynyt vuonna 1983 tai myöhemmin. Tavoiteltiin siis 12 vuoden ikärajaa mutta valvonnan kannalta helpommalla sääntelyllä kuin aikaisemmin.

Ruotsin charterverolaki, joka oli pääosin samanlainen kuin Suomen tilauslentoverolaki, kumottiin vuonna 1993. Suomen tilaus- 
lentovero loppui vuoden 1994 päättyessä, kun lain voimassaoloaikaa ei jatkettu eikä säädetty uutta veroa.

\subsubsection{Tietoliikenteen televero}

Valtion verotulojen lisäämiseksi säädettiin vuoden 1993 lopussa laki teleliikenteen verottamisesta. Uusia verokohteita etsittäessä oli tavoitteena löytää vero, joka kohdistuisi tasapuolisesti eri toimialoille mutta ei kohtuuttomasti rasittaisi kansantalouden kannalta keskeisiä toimintoja tai vaikeuttaisi heikoimmassa asemassa olevien kansalaisten toimeentuloa.

Televiestinnän liikennemaksuista valtaosa oli yritysten maksamia. Kotitaloudet kuluttivat yleisistä telepalveluista noin $30 \%$ ja matkaviestintäpalveluista noin 5\%. Datasiirtotoiminta oli lähes yksinomaan yritysten välistä. Julkisen sektorin osuus kaikkien telepalvelujen käytöstä oli alle $10 \%$. Televeron suorittamisvelvollisuuden katsottiin jakautuvan mahdollisimman laajasti toimialojen kesken.

Lakia säädettäessä myös arvioitiin, että telealalla vallitsevan kilpailun ja markkinoiden jatkuvan laajenemisen vuoksi teleliikenteeseen kohdistuva vero ei välttämättä nostaisi hintoja ainakaan veron koko määällä. Televeroa oli suoritettava $9 \%$ veron perusteesta eli telepalvelun verottomasta myyntihinnasta, siis hinnasta ilman televeron ja liikevaihtoveron/arvonlisäveron osuutta. Televero oli yksivuotinen eli vuotta 1994 koskeva, ja veron tuotoksi arvioitiin talousarviossa 0,5 miljardia markkaa, siis noin 100 miljoonaa euroa.

\subsection{Kulutusverot EU-jäsenyyden aikana}

\subsubsection{Tulli}

Vuoden 1995 alussa Suomi liittyi jäseneksi Euroopan unioniin, jonka keskeisiä periaatteita on tavaroiden vapaa liikkuvuus. Jäsenmaiden välisessä kaupassa ei kanneta tulleja, ja EU:n ulkopuolelta tuotavien tavaroiden tullit ovat unionin eivätkä jäsenvaltion tuloja. EU-jäse- 
nyyden seurauksena tullit ovat menettäneet merkityksensä Suomen valtiontaloudessa;tiettyä kantopalkkiota lukuun ottamatta jäsenvaltioiden on tuloutettava tullit unionille, jonka omiin rahoituslähteisiin ne kuuluvat.

\subsubsection{Arvonlisäverotus}

Arvonlisäverolaki, joka korvasi liikevaihtoverolain, tuli voimaan 1.6.1994. Arvonlisäverolakia muutettiin perusteellisesti vuoden 1995 alusta, kun Suomesta tuli EU:n jäsen ja osa sisämarkkina-aluetta. Myös alkutuottajat säädettiin arvonlisäverovelvollisiksi. Lakia on myöhemmin muutettu useita kertoja, ja samalla säännösten määrä on lisääntynyt valtavasti.

Yleistä arvonlisäverokantaa on Euroopassa viime vuosina nostettu. Korkein se on nykyisin Unkarissa (27 \%) ja Islannissa (25,5\%), sitten seuraavat Norja, Ruotsi ja Tanska 25 \%:n sekä Suomi ja Romania $24 \%$ :n verolla. EU-maiden alimmat yleiset arvonlisäveroprosentit ovat Saksassa ja Kyproksella (19 \%), Maltalla (18 \%) ja Luxemburgissa (15\%). Vielä alempi veroprosentti on Sveitsissä (8\%), mutta Sveitsi ei ole EU-valtio.

Suomen yleinen verokanta nostettiin 1.7.2010 lukien $23 \%$ :ksi ja alennetut verokannat $9 \%$ :ksi ja $13 \%$ :ksi. Vuoden 2013 alusta yleinen verokantamme korotettiin $24 \%$ :ksi ja alennetut verokannat $10 \%: k s i$ ja $14 \%: k s i$.

Arvonlisävero on nykyisin Suomen valtion verotuloista fiskaalisesti merkittävin. Vuonna 2017 arvonlisäveron tuotoksi arvioidaan noin 17 miljardia euroa, joka on $41 \%$ valtion verotuloista.

\subsubsection{Alkoholi-, tupakka- ja energiaverot}

Suomen liittyessä EU:n jäseneksi meillä säädettiin direktiivien määräysten toimeenpanemiseksi uusi alkoholiverolaki. Vero määräytyy tuotteen etyylialkoholipitoisuuden tai juoman määrän mukaan.

EU:ssa harmonisoidun tupakkaverotuksen veropohjaan kuuluvat tuotteet ovat savukkeet, sikarit ja pikkusikarit sekä piippu- ja savuketupakka. Suomessa kannetaan kansallistakin valmisteveroa, kun 
verollisiksi on säädetty myös muut tupakkaa sisältävät tuotteet sekä savukepaperi. Suomi kantaa nykyisin tupakkaveroa myös suunuuskasta, purutupakasta ja nenänuuskasta. Veromäärien osalta EU:ssa on kyetty sopimaan vain jäsenvaltioissa sovellettavista vähimmäisverotasoista, minkä vuoksi eri maiden verokannoissa on huomattavia eroja.

Mineraaliöljyistä kannettavat polttoaineverot kuuluvat EU:ssa harmonisoituihin veroihin. EU:ssa lähtökohtana on, että veroa kannetaan kaikista moottoripolttoaineina tai lämmityspolttoaineina käytettävistä tuotteista. Tietyt mineraaliöljyt ovat lähtökohtaisesti käyttötarkoituksesta riippumatta veronalaisia, ja niille on vahvistettu tietyt vähimmäisveromäärät. Nämä tuotteet ovat lyijyllinen ja lyijytön moottoribensiini, kaasuöljy, nestekaasu, metaani ja lentopetroli. Kaasuöljylle, nestekaasulle, metaanille ja lentopetrolille on vähimmäisverotasot toisaalta niiden käytölle teollisuudessa ja toisaalta niiden käytölle polttoaineena ja lämmitykseen.

Polttoaineverotuksemme muuttui EU-jäsenyyden myötä. Vain osa aikaisemmin veronalaisista tuotteista kuuluu EU:ssa harmonisoidun polttoaineverotuksen piiriin. Muiden tuotteiden (kivihiilen, sähkön, maakaasun ja jyrsinpolttoturpeen) osalta jouduttiin arvioimaan valmisteverotuksen jatkamista kansallisen valmisteverotuksen pohjalta. Suomessa katsottiin, että näiden energialähteiden verottamista oli ympäristöperusteisten syiden vuoksi tarpeen jatkaa. Veroa säädettiin kannettavaksi myös mäntyöljystä ja palaturpeesta.

Alun perin polttoainemaksulaki, jolla pyrittiin varmistamaan verotuksellisesti oikean polttoaineen käyttö ajoneuvossa, ei koskenut henkilöautoja, mutta lain soveltamisalaa laajennettiin vuonna 1998, jotta järjestelmä olisi EU-velvoitteiden mukainen. Muutoksen jälkeen polttoainemaksun soveltamisala läheni sille rinnasteisen veron eli moottoriajoneuvoveron lisäveron soveltamisalaa. Tiettyjä eroja kuitenkin vielä jäi. Polttoainemaksua esimerkiksi ei kannettu minkäänlaisista traktoreista, kun taas lisäverosta oli vapautettu vain traktorien tietynlainen käyttö. Eroja oli myös eräiden työkoneiden verokohtelussa. Sekä moottoriajoneuvoverolain lisäveroa koskevien säännösten että polttoainemaksulain tarkoituksena oli säädellä eri polttoainelaatujen käyttöä ajoneuvoissa. Lainsäädännön jakautumista kahteen lakiin ja järjestelmien osittaista päällekkäisyyttä voitiin arvostella, mutta 
säännösrakenne oli muotoutunut tuollaiseksi ennen muuta lainsäädäntöhistoriallisista syistä.

Vuoden 2004 alusta tuli voimaan uusi laki polttoainemaksusta. Siihen otettiin säännökset, jotka koskivat seuraamuksia moottoribensiiniä tai dieselöljyä lievemmin verotettujen polttoaineiden ja eräiden kaasumaisten polttoaineiden käytöstä ajoneuvoissa. Aikaisemmin eri laeissa olleet seuraamukset yhdistettiin polttoainemaksu-nimiseksi yhdeksi järjestelmäksi. Päiväkohtainen polttoainemaksu on esimerkiksi henkilöautosta 330 euroa, pakettiautosta 500 euroa, linja-autosta 670 euroa ja kuorma-autosta 1000 euroa.

Suomi säilytti sähköveron liittyessään Euroopan unioniin. Sähköverossa on kysymys kansallisesta valmisteverosta, jota ei ole EU:ssa harmonisoitu. Sähköverotus uudistettiin vuonna 1997 voimaan tulleen energiaverouudistuksen yhteydessä. Katsottiin, että ympäristöperusteisen verotuksen noudattaminen sähkön verotuksessa oli aiheuttanut ongelmia Suomen teollisuuden kansainväliselle kilpailukyvylle. Uudistukseen johtaneena syynä olivat myös tuontisähkön verottamisen EU-oikeudelliset ongelmat.

Alkoholin, tupakan ja energian valmisteverojen fiskaalinen merkitys on erittäin suuri. Niiden yhteinen osuus Suomen valtion verotuloista oli esimerkiksi vuonna 2016 noin $17 \%$.

\subsubsection{Makeis-, jäätelö- ja virvoitusjuomavero}

Suomen liittyminen EU:n jäseneksi johti valmisteverolainsäädäntömme kokonaisuudistukseen. Vaikka makeis- ja virvoitusjuomaverojen valtiontaloudellinen merkitys oli muihin valmisteveroihin verrattuna pieni, ei näiden verojen kantamisesta EU-jäsenyydenkään jälkeen katsottu voitavan meillä luopua. Nyt säädettiin kansallinen laki makeis- ja virvoitusjuomaverosta. Siihen sisällytettiin molempia veroja koskevat säännökset.

Virvoitusjuomaverotuksessa tapahtui EU-jäsenyyden myötä joitakin muutoksia. Aiemmin Suomessa ei kannettu eräistä kotimaisista marjoista valmistetuista virvoitusjuomista virvoitusjuomaveron perusveroa. Koska tällaisen verottomuuden tavoitteet liittyivät kotimaisen tuotannon suojaamiseen, ei verottomuutta EU-säännösten 
vuoksi voitu sisällyttää enää uuteen lakiin. Tämä lisäsi verovelvollisten määrää.

Makeisten valmisteverotus säilyi pääosin entisellään. Siinä otettiin kuitenkin käyttöön koivusokeria sisältävien makeisten eli ksylitolimakeisten verottomuus. Lakialoitteen ksylitolimakeisten verottomuudesta oli allekirjoittanut toistasataa kansanedustajaa. Valtiovarainvaliokunta ehdottikin vapautettavaksi verosta "sellaiset tuotteet, joiden kiistatta on osoitettu olevan hampaille terveellisiä". Verottomiksi säädettiin makeiset, jotka oli makeutettu koivusokerilla siten, että sen osuus tuotteen makeuttajista oli vähintään $50 \%$. Lisäksi edellytyksenä oli, että tuotteessa ei käytetty sakkaroosia, glukoosia, tärkkelyssiirappia, hedelmäsokeria eikä muita helposti käymiskelpoisia bakteeriaineenvaihduntaan soveltuvia makeuttajia eikä sitruunahappoa tai muita vastaavia happoja, jotka aiheuttavat hampaiden kemiallista syöpymistä.

Makeisvero poistettiin Suomen verojärjestelmästä vuonna 1999. Hallituksen esityksessä todettiin, että yhdenmukaistettaessa valmisteverotusta koskevaa lainsäädäntöä Suomen valmistautuessa EU-jäsenyyteen kansallisen makeisveron kantamista oli jatkettu valtiontaloudellisista syistä. Makeisten harmaatuontia pitivät kauppa ja makeisteollisuus makeisverotuksesta johtuvana ongelmana. Verottomasti maahantuotujen makeisten katsottiin aiheuttavan kilpailun vär̈istymiä, koska niitä myytiin edullisemmin kuin verollisia makeisia. Viranomaiset eivät kuitenkaan olleet todenneet makeisveron kiertämisestä aiheutuneen merkittäviä ongelmia. Tutkitut rikokset olivat yleensä olleet vähäisiä ja niiden vaikutukset markkinoilla paikallisia. Myös makeisveron tuotto oli hieman noussut, joten suurimittaista salakuljetettujen makeisten myyntiä ei voitu katsoa esiintyvän.

EU-säädökset kielsivät jäsenvaltioita määräämästä muiden jäsenvaltioiden tuotteille korkeampia veroja kuin samanlaisille kotimaisille tuotteille. Euroopan komissio oli lähettänyt Suomelle vuonna 1997 virallisen huomautuksen, jossa katsottiin, että Suomi oli rikkonut velvoitteet pitäessään voimassa ksylitolimakeisten verovapauden suhteessa muihin tavallista sokeria sisältämättömiin, muilla sokerialkoholeilla kuin ksylitolilla, kuten sorbitolilla, makeutettuihin ja muista jäsenvaltioista peräisin oleviin makeisiin. Suomi oli toimittanut komissiolle 
vastauksensa, jossa katsottiin, ettei kyse ollut tuontituotteita syrjivästä verosta. Ksylitolimakeisten verovapaus oli myönnetty makeisten sisältämien makeutusaineiden perusteella, ei makeisten alkuperän perusteella. Näin tuontimakeiset saivat saman veroedun kuin kotimaiset tuotteet, jos ne täyttivät laissa säädetyt verottomuuden edellytykset. Suomessa myytiin sekä kotimaassa että ulkomailla valmistettuja ksylitolimakeisia. Toisaalta makeisveroa kannettiin merkittävästä määrästä kotimaisia sokerittomia makeisia, jotka oli makeutettu muulla kuin ksylitolilla.

Suomi oli saanut komissiolta myös veron kantojärjestelmää koskevan epävirallisen huomautuksen. Siinä katsottiin, että toisesta jäsenvaltiosta vastaanotetut tuotteet olivat epäedullisemmassa asemassa kotimaasta tehtyyn hankintaan verrattuna. Kirjelmässä todettiin myös, että oli suhteetonta soveltaa samanlaisia säännöksiä vähäisten kansallisten valmisteverojen kantamiseen kuin tuottoisiin yhdenmukaistettuihin valmisteveroihin. Vastauksessaan komission epäviralliseen huomautukseen Suomi katsoi, että veron kantojärjestelmä oli mahdollisimman yksinkertainen eli pelkkä veron maksaminen riitti. Se, joka toi tuotteita toisesta jäsenvaltiosta, ei joutunut syrjivän veron kohteeksi.

Kansallisesta valmisteverosta Suomen makeismarkkinoille aiheutuvien ongelmien vuoksi hallitus esitti makeisverosta luopumista. Makeisveron kumoaminen ei näy synnyttäneen eduskunnassa minkäänlaista vastustusta, ja valtiovarainvaliokunnan mietintökin oli tältä osin yksimielinen. Makeisvero kumottiin vuoden 1999 alusta, mutta virvoitusjuomavero säilytettiin.

Makeisvero herätettiin Suomessa uudelleen henkiin 2010-luvun alussa. Hallitus perusteli tätä fiskaalisilla syillä, mutta asian käsittelyn yhteydessä esillä olivat myös terveyspoliittiset näkökohdat. Hallitus totesi väitetyn, että ehdotettu vero syrjisi joitakin yrityksiä ja vääristäisi näin elintarvikealan yritysten välistä kilpailua. Jotkut esittivätkin, että veropohjaa tulisi laajentaa muihin samankaltaisiin tuotteisiin, kuten kekseihin, makeisiin leivonnaisiin, hilloihin ja jogurtteihin. Tätä hallitus ei kuitenkaan esittänyt. Hallitus sanoi tavoitteena olevan, että vero kohdistuisi tasapuolisesti kaikkiin makeisiin, jäätelöihin ja alkoholittomiin juomiin. Tavoitteena oli myös, että veron kantojärjestelmä olisi riittävän yksinkertainen ja yksiselitteinen. 
Hallitus totesi, että makeisten tavoin sokeria sisältäviä elintarvikkeita olivat esimerkiksi keksit, kakut, jäätelö, kuivatut ja mahdollisesti kuorrutetut hedelmät ja vihannekset, hillot, murot ja perunalastut. Erityisesti keksit ja muut leipomatuotteet koettiin usein makeisten kaltaisiksi tuotteiksi. Kakkujen, leivosten, pullien, keksien sekä muiden niiden kaltaisten makeiden leipomatuotteiden verottaminen oli kuitenkin ongelmallista, koska sellaisia tuotteita ei luokiteltu yhdistetyssä nimikkeistössä omiksi alanimikkeikseen. Makeat leipomatuotteet sisältyivät tullitariffin nimikkeeseen numero 1905, joka sisälsi myös sellaisia tuotteita, joita ei voitu pitää makeisten kaltaisina; tästä esimerkkeinä ruokaleipä ja muut suolaiset leipomatuotteet. Veronalaisten tuotteiden rajaaminen ryhmästä numero 1905 siten, että vältettäisiin samankaltaisten tuotteiden erilainen kohtelu, olisi erittäin vaikeaa. Epätarkkuus veron kohteena olevan tuotteen määritelmässä aiheuttaisi epävarmuutta siitä, kuuluuko tuote verotuksen piiriin.

Esityksen perusteluissa todettiin, että lausunnoissa oli otettu kantaa ehdotuksen terveysvaikutuksiin puolesta ja vastaan. Lausunnoissa katsottiin, että ehdotus edistää kansalaisten terveyttä ja on siksi kannatettava. Toisaalta lausunnoissa katsottiin epäkohdaksi, että verotus kohdistuisi myös terveellisiin lähde- ja kivennäisvesiin ja ksylitolituotteisiin. Lisäksi katsottiin, ettei sokerin eikä minkään muunkaan yksittäisen elintarvikkeen yhdistämiselle lihavuuden yleistymiseen ollut perusteita. Hallitus totesi, että esityksen tarkoituksena oli valtion tulojen kasvattaminen eikä esitykselle ollut asetettu terveystavoitteita.

Laki makeis-, jäätelö- ja virvoitusjuomaverosta tuli voimaan vuoden 2011 alussa. Kesällä 2011 toimintansa aloittaneen niin sanotun sixpack-hallituksen ohjelmassa luvattiin laajentaa makeisten ja jäätelön valmisteveron pohjaa ja nostaa verotasoa ja näin lisätä valtion verotuloja. Makeisten ja jäätelön valmisteveron korvaaminen sokeriverolla luvattiin selvittää. Sokeriverotyöryhmä suoritti toimeksiantonsa mukaisen tehtävän ja pohti vaihtoehtoisia sokeriveromalleja. Myös työryhmän raportin (Valtiovarainministeriön julkaisuja 3/2013) mukaan sokeriveron toteuttamisessa kuitenkin olisi suuria vaikeuksia.

Vuonna 2015 makeis-, jäätelö- ja virvoitusjuomaveron tuotoksi arvioitiin 256 miljoonaa euroa, josta juomien osuus olisi 147 miljoonaa euroa ja makeisten ja jäätelön osuus 109 miljoonaa euroa. 
Pääministeri Sipilän hallitus päätti, että makeisilta ja jäätelöltä poistetaan vero vuoden 2017 alussa mutta virvoitusjuomien vero säilytetään. Makeisten ja jäätelön verosta luopumista perusteltiin sillä, että verosta oli tehty komissiolle kaksi valtiontukikantelua. Toistaiseksi epävirallisessa menettelyssä komissio oli ilmoittanut Suomelle, että se piti nykymuotoista, tullinimikkeisiin sidottua ja valtiontaloudellisin perustein kannettavaa veroa valtiontukisääntöjen vastaisena. Vero ei komission mukaan kohdellut samankaltaisia tuotteita veron tavoitteen kannalta neutraalisti ja sisälsi siksi valtiontueksi katsottavaa valikoivaa verotukea veron ulkopuolelle jääville tuotteille. Komissio katsoi, että muutokset veropohjaan olivat välttämättömiä. Jos verojärjestelmän katsotaan sisältävän kiellettyä valtiontukea, riskinä oli veron takaisinperintä veron ulkopuolelle jääneiltä tuotteilta kymmeneltä vuodelta korkoineen. Veropohjan laajentaminen uusiin tuoteryhmiin merkitsisi lisääntyvää hallinnollista taakkaa veron piirissä oleville toimijoille eikä välttämättä ratkaisisi neutraalisuusvaatimusta.

Hallituksen esityksen mukaisesti makeis- ja jäätelöveron kumoamisesta johtuva verotulojen väheneminen korvattiin polttoaineveroa korottamalla. Se olikin helppo ratkaisu, kun öljyn hinta oli olennaisesti laskenut.

\subsubsection{Jätevero}

Suomen nykyisen jäteveron juuret ovat lyhyet: syyskuussa 1996 alettiin kantaa jäteverolain nojalla erityistä veroa kaatopaikalle toimitettavasta jätteestä. Laki korvattiin uudella jäteverolailla vuoden 2011 alusta alkaen, jolloin jätevero korotettiin 30 eurosta 40 euroon jätetonnilta ja veron veropohja laajennettiin koskemaan yleisten kaatopaikkojen lisäksi myös yksityisiä kaatopaikkoja. Samalla päätettiin jäteveron korottamisesta 50 euroon jätetonnilta vuonna 2013. Vuonna 2015 vero korotettiin 55 euroon jätetonnilta. Verotuksen piiriin kuuluvat jätelajit ilmenevät lain liitteenä olevasta taulukosta.

Jäteverolla on ympäristöpoliittisia ohjausvaikutuksia. Sen kustannusrasituksia voi välttää tuottamalla mahdollisimman vähän veron piiriin kuuluvaa jätettä. Veron säätämistä koskevassa hallituksen esityksessä todettiin kysymyksessä olevan perusominaisuuksiltaan 
valmisteveroa muistuttava vero. Valtion talousarviossa tätä veroa ei kuitenkaan sisällytetty valmisteverojen ryhmään vaan muiden verojen ryhmään yhdessä muun muassa autoveron kanssa.

Jäteveroon liittyy erityispiirteitä sen kulutusveroluonteen kannalta. Vaikka jäteveroa voidaan pitää kulutusveron luonteisena, se eroaa kuitenkin tavanomaisista valmisteveroista sen suhteen, mihin hyödykkeen elinkaaren vaiheeseen vero kohdistuu. Esimerkiksi alkoholi- ja tupakkaveroja kannetaan tuotteista, joilla tyydytetään ihmisten tietynlaisia tarpeita. Jätevero kohdistuu aivan kulutuksen loppuvaiheessa olevaan hyödykkeeseen, jätteeseen. Jäteveron luonteen kannalta ei ole myöskään selvää, pidetäänkö tätä veroa tavaran vai palvelun verona. Lain esitöissä todetaan kyseessä olevan lähtökohtaisesti tavaran eli jätteen erityinen vero, mutta koska jäteveroa kannetaan nimenomaan kaatopaikalle toimitettavasta jätteestä, voidaan ajatella niinkin, että kaatopaikanpitäjän tarjoamien toimintojen kautta kysymyksessä on myös palveluun kohdistuva vero.

Jätevero tuotti 45 miljoonaa euroa vuonna 2009. Veron tuotoksi vuonna 2011 odotettiin 90 miljoonaa euroa, mutta kertymä oli vain 64 miljoonaa. Jäteveron tuotto on kutistunut senkin jälkeen erityisesti orgaanisen jätteen kaatopaikkasijoittamisen kiellon takia. Tämän veron arvioidaan tuottavan vuonna 2017 enää 22 miljoonaa euroa.

\subsubsection{Autovero}

Vuoden 1995 alusta tuli voimaan autoverolaki, joka korvasi vanhan lain auto- ja moottoripyöräverosta. Uuden lain säätäminen tuli ajankohtaiseksi Suomen EU-jäsenyyden vuoksi, koska jouduttiin siirtymään järjestelmään, jossa verotusta ei enää toimiteta rajamuodollisuuksien yhteydessä. Autoverolakiin siirrettiin osa aikaisemmista tullisäännöksistä mukautettuina EU:n sisämarkkinoita koskeviin säännöksiin. Keskeisimmät autoverolain uudistukset koskivat verovelvollisuutta, verotusarvon määräämistä ja veron maksuunpanon ajankohtaa, mutta yleinen verotaso pidettiin ennallaan. Autoverolakiin otettiin uusitut säännökset käytettyinä maahan tuotavista ajoneuvoista; myös vuoden 1998 lopussa säädetyt muutokset koskivat käytettyjen autojen tuontia ja johtuivat Suomen EU:Ita saamasta 
virallisesta huomautuksesta. Muutoksia pidettiin kuitenkin yleisesti riittämättöminä.

EU:n tuomioistuin oli 1990-luvulla antanut useita päätöksiä, joissa lähdettiin siitä, että toisesta jäsenvaltiosta tuodusta käytetystä ajoneuvosta ei saanut periä autoveroa enempää kuin oli vastaavanlaisen auton arvoon sisältyvä veron jäljellä oleva osuus. Suomen osalta asia tuli EU:n tuomioistuimessa vireille KHO:n tehtyä 15.3.2000 asiasta ennakkoratkaisupyynnön. Uutena ongelmana oli nyt, miten suhtautua kauppaportaan verovaikutukseen. KHO teki EU:n tuomioistuimen antaman ennakkoratkaisun pohjalta päätöksensä 16.12.2002. Se totesi, että käytettynä maahan tuodun ajoneuvon ja sen vertailukohtana käytettävän samanlaisen maassa jo rekisteröidyn auton verotusarvo on laskettava samalla tavalla uuden auton arvon perusteella ja ottamatta huomioon kaupan eri vaiheita.

Hallitus antoi 30.12.2002 esityksen autoverolain muuttamisesta. Sen mukaan sekä uusien että käytettynä tuotavien henkilöautojen verotus perustui auton yleiseen kuluttajahintaan Suomessa. Verotasoa myös esitettiin alennettavaksi noin kuudenneksella. Esitys muuttui valtiovarainvaliokunnassa huomattavasti, ja eduskunta hyväksyi lain valiokunnan ehdottamassa muodossa. Keskeiset muutokset koskivat lain yleistä kirjoitustapaa. Muun muassa niin sanottua mallinnettua arvonmääritystä koskevia säännöksiä ei otettu lakiin. Jo tämä poisti olennaisesti sitä vaikeaselkoisuutta, josta esitystä oli arvosteltu. Se myös antoi mahdollisuuden säätää veron määräytymisperusteista helpommin ymmärrettävällä tavalla. Veron määrä muutettiin laskettavaksi verollisesta yleisestä vähittäismyyntiarvosta, ja näin tehtiin myös moottoripyörien osalta. Tämänkin jälkeen autoverotukseemme jäi paljon eurooppaoikeudellisia ongelmia.

Suomen autoverotuksessa toteutettiin vuoden 2008 alussa huomattava muutos, kun auton arvon pohjalta määritettävän autoveron veroprosentti porrastettiin auton hiilidioksidipäästötason mukaan. Verouudistuksen rakenteellinen lähtökohta oli huomion kiinnittäminen ympäristönäkökohtiin. Joidenkin autojen verotaso säilyi ennallaan, useimpien laski ja joidenkin nousi. Veromäärään tulivat vaikuttamaan auton arvo ja päästötaso. Henkilöautojen autoveron kiinteistä vähennyksistä luovuttiin, jolloin poistui myös se lievä progressiivisuus, jolla oli tavoiteltu veronmaksukyvyn huomioon ottamista 
suosimalla pieniä ja halpoja autoja. Toisaalta päästötaso (ja kokonaismassa) korreloi siinä määrin auton koon ja hinnan kanssa, että siinä voidaan katsoa otetun huomioon myös autonostajien veronmaksukykyä ja verotuksen progressiivisuutta.

Vuonna 2009 lakia muutettiin sitten, että luovuttiin perimästä autoverolle arvonlisäveron suuruista veroa (ns. elv). Lisäksi autoverolain säännöksiä verotettavasta tapahtumasta ja verovelvollisuudesta muutettiin siten, ettei autoveroa enää pääsääntöisesti tarvitse lukea ajoneuvon myynnistä suoritettavan arvonlisäveron perusteeseen. Muutosten seurauksena ajoneuvojen verotus ei kuitenkaan keventynyt, koska autoveroa korotettiin autoverolle suoritettua arvonlisäveroa vastaavalla määrällä.

Pakettiautojen vero muutettiin vuonna 2009 perustuvaksi henkilöautojen veron tavoin yleiseen vähittäismyyntihintaan. Samalla pakettiautojen vero porrastettiin auton hiilidioksidipäästöjen perusteella samalla tavalla kuin henkilöautojen vero. Alennettuun veroon oikeutettujen pakettiautojen tavaratilan vähimmäiskokoa koskevista vaatimuksista luovuttiin. Kookkaampien tavarankuljetukseen tarkoitettujen pakettiautojen kuljetuskyky kuitenkin otetaan huomioon hiilidioksidipäästöihin perustuvan veron määrää vähentävänä tekijänä. Niistä pakettiautoista, joista ei ole päästötietoa, veroa kannetaan nyt auton kokonaismassan ja käyttövoiman perusteella määräytyvän laskennallisen päästötiedon perusteella.

Autoveroa kertyy nykyisin noin 850 miljoonaa euroa vuodessa. Autoveron suhteellinen merkitys on viime aikoina vähentynyt; nykyisin autovero tuottaa noin $2 \%$ valtion verotuloista. Ajoneuvoveron merkitys on sen sijaan kasvanut niin, että ajoneuvovero on nykyisin jo lähes $3 \%$ valtion verotuloista. Verotuksen painopistettä on tietoisesti siirretty ajoneuvon käyttöönottovaiheesta ajoneuvon käytettävissäolovaiheeseen. Käyttövaiheen polttoainevero bensiinistä ja dieselöljystä tuottaa vuodessa peräti 2,6 miljardia euroa.

\subsubsection{Ajoneuvovero}

Vanhaa ajoneuvoverolakia pidettiin työläänä. Hankalaa oli, että ajoneuvojen käyttäjät itse joutuivat käymään ostamassa veromerkin ja 
kiinnittämään sen ajoneuvon tuulilasiin, varsinkin kun heidän oli samalla poistettava tuulilasista aikaisempi veromerkki.

Eduskunta edellytti hallituksen ryhtyvän toimiin veron kantamiseksi vuotta lyhyemmiltä ajanjaksoilta ja vammaisten käyttämien ajoneuvojen verovapauden toteuttamiseksi. Hallitus antoikin lokakuussa 1996 esityksen uudeksi laiksi ajoneuvoverosta, ja vuonna 1997 siirryttiin kantamaan vero veromerkin sijasta verolipuilla. Keskeisenä tavoitteena oli hyödyntää atk-sovelluksia. Vuodesta 1999 lukien lakia muutettiin ottamalla käyttöön järjestely, jonka mukaan verovelvolliselle palautettiin veroa, jos ajoneuvo poistettiin rekisteristä verokauden aikana.

Vuonna 2004 voimaan tulleiden ja yhä rakenteeltaan voimassa olevien säännösten keskeisenä tavoitteena oli lainsäädäntötekninen uudistus, jolla ajoneuvoveron ja moottoriajoneuvoveron järjestelmät voitiin optimoida soveltuviksi uudistuviin tietotekniikkaratkaisuihin. Ympäristö- ja liikennepoliittiset tavoitteet jätettiin tuossa vaiheessa sivuun.

Kun verokausi voi ajoneuvokohtaisesti vaihdella siten, että se voi päättyä jo ennen 12 kuukauden enimmäisajan päättymistä, ja kun verokausi ei muutoinkaan noudata kaikille ajoneuvoille yhteistä esimerkiksi kalenterivuoteen perustuvaa verokautta, oli luontevaa luopua ilmaisemasta veron määrää vuotuiseksi veroksi laskettuna. Verojen määrästä säädetäänkin nykyisessä laissa päiväkohtaisena verona.

Hallitus antoi vuoden 2007 lopulla esityksen henkilöautoista kannettavan ajoneuvoveron perusveron muuttamisesta hiilidioksidipäästötasoihin perustuvaksi. Esitys annettiin samalla kertaa kun autoverotuksessa toteutettiin uudistus, jossa veromäärä porrastettiin auton päästötason mukaan. Uudistuksessa korostettiin ympäristönäkökohtia. Uudella verolla pyrittiin keräämään valtiolle entinen veromäärä. Niistä ajoneuvoista, joista ei ole päästötietoa, vero määräytyy kokonaismassan perusteella. Trafin tietojärjestelmämuutosten vaatiman ajan takia muutos tuli voimaan vasta 2010 -luvun alussa. - Veromääriä on myöhemmin korotettu. Ajoneuvovero tuottaa nykyisin valtiolle vuodessa runsaat 1,1 miljardia euroa, joka on jo selvästi enemmän kuin autoveron tuotto. 


\subsubsection{Huviveneiden polttoainemaksu}

Huviveneilyssä käytettävän polttoaineen verottomuudelle ei ole energiaverodirektiivissä säännöksiä. Suomi haki EU:lta 20.11.2006 mahdollisuutta käyttää kevyttä polttoöljyä huviveneiden polttoaineena. Komissio ilmoitti 15.3.2007 kielteisen kantansa.

Dieselmoottorilla varustetuissa aluksissa oli meillä käytetty lievästi verotettua kevyttä polttoöljyä. Poikkeuksen päättyminen tarkoitti, että dieselveneilijöiden huviveneissä käyttämä polttoaine muuttui dieselöljynä verotettavaksi. Muutoksen toteuttaminen edellytti lainsäädäntöön lievemmin verotetun polttoaineen käyttökieltoa huviveneissä sekä valvontaa ja sanktiota niitä tilanteita varten, joissa kiellon vastaisesti käytettiin huviveneen polttoaineena esimerkiksi kevyttä polttoöljyä.

Tämän vuoksi säädettiin vuoden 2008 alusta laki yksityisestä huvialuksesta suoritettavasta polttoainemaksusta. Polttoainemaksu pannaan maksuun, jos dieselmoottorilla varustetussa yksityisessä huvialuksessa havaitaan käytetyn dieselöljyä lievemmin verotettua tai verotonta polttoainetta taikka jos bensiiniä käyttämään tarkoitetussa yksityisessä huvialuksessa havaitaan käytetyn moottoribensiiniä lievemmin verotettua tai verotonta polttoainetta. Polttoainemaksu määräytyy valmistajan ilmoittaman konetehon mukaan portaittain. Tehon ollessa enintään $50 \mathrm{~kW}$, vero on 750 euroa. Ylintä polttoainemaksua, joka on 4000 euroa, suoritetaan konetehon ollessa yli 200 $\mathrm{kW}$. Polttoainemaksua voidaan korottaa enintään $50 \%: 1 l a$, jos kielletyn, polttoainemaksun aiheuttavan polttoaineen käyttö toistuu, ja enintään $100 \%: 1 l a$, jos käyttö on erityisen törkeää.

Kysymyksessä on samantapainen suoritus kuin autojen polttoainemaksu. Koska polttoainemaksujärjestelmä täyttää tavoitteensa sitä paremmin, mitä vähemmän tuota veronluonteista maksua on suoritettava, on ymmärrettävää, että polttoainemaksua kertyy niin vähän, ettei sitä erikseen näy valtion talousarviossa eikä tilinpäätöksessä. Maksun fiskaalinen merkitys on siinä, että sen avulla turvataan polttoaineveron kertymää. 


\subsubsection{Väylämaksu ja ratavero}

Nykyinen vesiliikenteen väylämaksulaki on ollut voimassa vuoden 2006 alusta. Sillä uudistettiin väylämaksun perusteita koskevia säännöksiä, jotka koskevat aluksesta suoritettavan väylämaksun määräytymistä. Väylämaksulaki saatettiin vastaamaan verolain vaatimuksia. Maksu määräytyy pääsääntöisesti aluksen jääluokkaan perustuvan yksikköhinnan sekä aluksen nettovetoisuuden perusteella. Se määräytyy nykyisen lain mukaan samojen perusteiden mukaisesti kotimaanliikenteessä ja ulkomaanliikenteessä oleville aluksille. Aluksen jääluokan määräytymistä koskevat säännökset poistettiin väylämaksulaista ja siirrettiin lakiin alusten jäluokista ja jäänmurtaja-avustuksesta. Tulli vastaa väylämaksatuksen toimittamisesta ja valvonnasta. Väylämaksu suoritetaan, kun alus saapuu ulkomailta Suomeen tai suomalaisesta satamasta suomalaiseen satamaan.

Junaliikenteen ratamaksusä̈̈nnökset muutettiin 2000-luvun alussa. Perustuslakivaliokunta totesi vuonna 2002 lausunnossaan hallituksen esityksestä rautatielaiksi, että ratamaksusäännöksiä oli tarkasteltava siltä kannalta, mitä perustuslain 81 \$:ssä säädetään valtiolle kannettavista veroista ja maksuista. Maksulle on ominaista, että se on korvaus tai vastike julkisen vallan palvelusta; muut rahasuoritukset valtiolle sen sijaan ovat veroja. Perustuslakivaliokunta katsoi, että ainoastaan ratamaksun perusmaksu on valtiosääntöoikeudellisessa mielessä maksu. Niukkuusmaksulla, investointimaksulla ja varausmaksulla on maksulle ominaisella tavalla yhteys viranomaisen suoritteisiin, mutta toisaalta niihin sisältyy vastikkeen ylittäviä suorituksia, ja tästä syystä niiden säätely olisi tarkistettava vastaamaan verolain vaatimuksia. Lisämaksu ja haittamaksu olivat valiokunnan käsityksen mukaan valtiosääntöoikeudellisessa mielessä veroja.

Perustuslakivaliokunnan lausunnon johdosta muita maksuja kuin perusmaksua koskevat säännökset poistettiin rautatielaista. Lain voimaantulon jälkeen ratamaksuna perittiin ainoastaan ratamaksun perusmaksua. Koska tarkoituksena oli, että rautatieliikenteen harjoittamiseen kohdistuisivat aikaisempia kustannuksia vastaavat kustannukset, säädettiin vuonna 2003 rataverolaki, joka sisältää veroja ja veronluonteisia maksuja koskevat säännökset. 
Vero perustuu kapasiteetti- ja ratamaksudirektiivissä tarkoitettuun haittamaksuun ja lisämaksuun. Haittamaksussa voidaan ottaa huomioon junan toiminnasta aiheutuvien ympäristövaikutusten kustannukset. Lisämaksua voidaan periä markkinoiden niin salliessa infrastruktuurin käytöstä aiheutuneiden kustannuksien täysimääräiseksi kattamiseksi.

\subsection{Yhteenveto kulutusverotuksen historiasta}

Kehitystä on jo pitkään leimannut yleisen kulutusverotuksen kasvu erityisen kulutusverotuksen kustannuksella. Tätä kehitystä vauhditti voimakkaasti maamme liittyminen Euroopan unioniin. Lisääntyvä mielenkiinto ympäristönsuojelun taloudelliseen ohjaukseen niin sanotulla haittaveroilla on kuitenkin edesauttanut joidenkin erityisten kulutusverojen säilymistä verojärjestelmässä. Huonosti on kuitenkin käynyt useimmille pienituottoisille pisteveroille. 


\section{2 \\ Venevero hallitus- \\ ohjelmassa 2015 ja \\ valtiovarainministeriön \\ esitysluonnoksessa 2016}

\subsection{Tavoitteet ja toteuttamisvaihtoehdot}

Pääministeri Juha Sipilän hallituksen ohjelmassa vuonna 2015 oli kirjaus ottaa käyttöön venevero ja moottoripyörien ajoneuvovero valtion verotulojen lisäämiseksi 50 miljoonalla eurolla. Valtiovarainministeriö ryhtyi valmistelemaan asiasta hallituksen esitystä, ja joulukuussa 2016 ministeriö lähetti esitysluonnokset lausunnolle. Jäljempänä esityksellä tarkoitetaan tuota esitysluonnosta.

Seuraavaksi selostetaan tuota esitystä, mutta esityksen arviointi tapahtuu vasta kirjan myöhemmissä luvuissa. Moottoripyörien ajoneuvoveroa ei tässä kirjassa käsitellä, vaan sitä selvitetään vuodenvaihteessa 2017/2018 ilmestyvässä teoksessa "Autoveron saattohoito ja tieliikenneverotuksen kehittäminen”.

Ministeriön veneveroesityksessä todettiin, että menettelyllisesti käytännössä yksinkertainen ja vähän verotuskustannuksia aiheutta- 
2 Venevero hallitusohjelmassa 2015 ja valtiovarainministeriön...

va tapa olisi säätää vesikulkuneuvoille kalenterivuoteen sidottu vero, jonka veneilijät maksaisivat oma-aloitteisesti. Veron kantaminen voitaisiin toteuttaa myös siten, että veneilijät hankkisivat vuosittain veneisiin kiinnitettävän verotarran. Tarralla kannettava vero voisi olla valvonnallisesti hieman selkeämpi kuin muihin veronmaksutositteisiin tai suoraan rekisteritietoihin perustuva vero, mutta se ei poistaisi rekisteritietojen käyttötarvetta kokonaan. Lisäksi väärinkäytöstilanteissa vero olisi joka tapauksessa pantava maksuun viranomaistoimin. Tarrojen avulla kannettavan veron ongelmana olisivat myös korkeat tarrojen hankinta- ja jakelukustannukset. Koska veron maksamisesta huolehtiminen jäisi yksin veneilijän hoidettavaksi, olisi todennäköistä, että maksamatta jättäminen olisi tahallisuuden, huolimattomuuden tai tietämättömyyden takia yleistä. Tämän takia veron valvontaan tarvittaisiin huomattavasti resursseja.

Toisena vaihtoehtona esityksessä mainittiin viranomaisaloitteisesti maksuunpantava vero, joka autoihin kohdistuvan ajoneuvoveron tapaan perustuisi rekisteritietoihin ja jossa muutoinkin pitkälti noudatettaisiin ajoneuvoverotuksessa omaksuttuja menettelyjä. Tämän vaihtoehdon toteuttamista hankaloittivat rekisteritietojen puutteellisuuden ohella Ahvenanmaan ja muun Suomen rekisteröintivaatimusten erot, joita ei voida eduskuntalailla poistaa maakunnan osalta. Koska veneiden rekisteri ei perustu EU-lainsäädäntöön, on Ahvenanmaalla myös mahdollisuus itsehallinnon puitteissa muuttaa veneiden rekisteröinnin perusteita tai luopua rekisteröintivelvollisuudesta. Jos vero olisi Manner-Suomen osalta sidottu rekisteritietoihin, olisi ratkaistava se, miten Ahvenanmaalla käytössä olevat vesikulkuneuvot verotetaan. Valtakunnan toimivaltaan kuuluvan verotuksen tulee kuitenkin koskea yhdenmukaisin perustein myös Ahvenanmaalla käytössä olevia veneitä. Ahvenanmaalla käytössä oleviin vesikulkuneuvoihin jouduttaisiin tällöin soveltamaan joiltain osin erilaista verotusmenettelyä kuin Manner-Suomessa käytössä oleviin.

Esityksessä todettiin, että veroperusteiden kannalta hallinnollisesti yksinkertaisin ja selkein toteutustapa olisi tasasuuruinen vero. Kaikille vesikulkuneuvoille samansuuruista veroa voitaisiin kuitenkin pitää oikeudenmukaisuuden kannalta ongelmallisena. Jollei veroa haluta säätää kaikille samansuuruiseksi, veron tulee käytännön syistä perustua johonkin rekisteritiedoissa kaikista vesikulkuneuvoista saatavaan 
tekniseen ominaisuuteen tai niiden yhdistelmään. Kysymykseen tulevat tällöin lähinnä vain moottorin teho ja rungon pituus.

Esityksessä todettiin, että veroa ei ole mahdollista toteuttaa esimerkiksi arvoperusteisesti, koska vesikulkuneuvoista ei ole arvotietoa saatavilla. Lisäksi teknisiltä ominaisuuksiltaan samanlaisten alusten arvo vaihtelee huomattavasti aluksen tyypin, iän, kunnon, rakenteiden ja varusteiden mukaan. Veroa ei voida perustaa myöskään tiettyyn ympäristötekijään autojen ajoneuvoveron tavoin, jollei moottorin tehoa katsota polttoaineen kulutukseen korreloivana tällaiseksi perusteeksi.

\subsection{Veron kohde ja rajaukset}

Esityksessä venevero ehdotettiin rajattavaksi vesikulkuneuvoihin, joiden moottoriteho on vähintään 38 kilowattia (= n. 52 hv). Vero koskisi siten vain melko isotehoisella moottorilla varustettuja vesikulkuneuvoja. Sen ulkopuolelle jäisi suurin osa käytössä olevista perämoottorilla varustetuista veneistä. Näiden veneiden arvo sekä käyttö- ja muut kustannukset ovat tyypillisesti vähäisempiä, ja veron osuus veneilyn kustannuksista nousisi siten melko suureksi.

Yksinomaan moottoritehoon perustuva rajaus jättäisi veron ulkopuolelle myös varsin kookkaatkin purjeveneet. Oikeudenmukaisuussyistä esityksessä kuitenkin katsottiin, että veron tulisi koskea myös niitä, minkä takia veronalaisuuden ehdotettiin määräytyvän toissijaisesti vesikulkuneuvon rungon pituuden perusteella. Siten veronalaisuus olisi määritelty niin, että vero koskisi vesikulkuneuvoja, joiden moottorin tai moottoreiden yhteenlaskettu teho on valmistajan ilmoituksen mukaan vähintään 38 kilowattia, sekä vesikulkuneuvoja, joiden rungon pituus on venerekisterilain mukaan mitattuna vähintään yhdeksän metriä.

Verovapautusten ehdotettiin määräytyvän suoraan venerekisterilain mukaista rekisteröintivelvollisuutta koskevien poikkeusten perusteella. Rekisteröintivelvoitteesta ja siten verosta vapautettuja olisivat olleet ainoastaan Puolustusvoimien ja Rajavartiolaitoksen veneet, yksinomaan kilpailukäytössä olevat vesikulkuneuvot sekä ne alukset, jotka on merkitty alus- tai kalastusalusrekistereihin. 
2 Venevero hallitusohjelmassa 2015 ja valtiovarainministeriön...

Rekisteröintivelvoitteesta ja verosta vapaita olisivat olleet myös sellaiset Suomessa tilapäisesti käytettävät vesikulkuneuvot, joiden omistajalla tai haltijalla ei ole Suomessa kotikuntaa eikä kotipaikkaa. Veroa ei kannettaisi myöskään koetunnuksilla vesiliikenteeseen käytettävistä vesikulkuneuvoista.

Ehdotetuilla perusteilla veronalaisiksi tulisi Manner-Suomen puolella noin 93000 moottorivenettä ja muuta vesikulkuneuvoa ja Ahvenanmaalla arviolta vähän yli 3000 . Moottoritehon perusteella vero koskisi siten noin puolta rekisteröidyistä moottoriveneistä. Pituuden perusteella vero koskisi noin 9000 venettä, joista suurin osa olisi purjeveneitä. Veronalaisia olisi täten noin puolet rekisteröidyistä purjeveneistä. Ahvenanmaan purjeveneiden märä ei ole tiedossa, mutta todennäköisesti kysymys on joistakin sadoista veneistä.

\subsection{Veron peruste ja määrä}

Veron ensisijaiseksi perusteeksi ehdotettiin moottoritehoa ja toissijaiseksi veneen rungon pituutta. Veron määrä ehdotettiin porrastettavaksi moottoritehon perusteella. Käytettävissä olevista teknisistä tiedoista moottoritehon voi katsoa jonkin verran kuvastavan vesikulkuneuvon arvoa yleisellä tasolla, joten porrastaminen lisäisi hieman veron oikeudenmukaisuutta tasaveroon verrattuna.

Esityksen mukaan verotaso määräytyisi suoraan vesikulkuneuvon moottoritehon perusteella siten, että jokainen kilowatti suoraan vaikuttaisi veron määrään veron ala- ja ylärajan välillä. Tällä pyrittäisiin välttämään yhden veroportaan tai vain harvojen veroportaiden jyrkästä porrastuksesta aiheutuvat markkinavaikutukset vesikulkuneuvojen ja niiden moottoreiden kauppaan ja valmistukseen. Ajoneuvojen hiilidioksidipäästöihin perustuvassa verotuksessa on vastaava lähtökohta. Ehdotetulla veromallilla myös lievennettäisiin houkutusta ilmoittaa rekisteriin väärä tieto moottoritehosta tai vaihtaa moottori pienempitehoiseen.

Veron vuotuiseksi määräksi ehdotettiin 100 euroa vesikulkuneuvolle, jossa on vähintään 38 kilowatin tehoinen moottori. Tämän tehon ylittävältä osalta vero kasvaisi kahdella eurolla kultakin täydel- 
tä kilowatilta, jolloin esimerkiksi 39 kilowatin tehoiselta moottorilta vero olisi 102 euroa vuodessa.

Veron enimmäismääräksi ehdotettiin 300 euroa, joka vastaisi 138 kilowatin eli noin 188 hevosvoiman moottoritehoa. Moottoritehon kasvaessa tätä suuremmaksi veron määrä ei enää nousisi. Tällä rajauksella pyrittiin välttämään veron nouseminen suhteettoman suureksi erityisesti niissä yksittäisissä tapauksissa, joissa moottoriteho ei välttämättä suoraan kuvasta vesikulkuneuvon arvoa. Raja-arvoa tehokkaampien moottoriveneiden osuus venekannasta on myös melko vähäinen, joten verotuoton kannalta veron määrällä ei näiden veneiden osalta olisi suurta merkitystä.

Moottori- ja purjeveneen rungon pituuteen perustuvaksi veroksi ehdotettiin 100 euroa, joka vastaisi moottoritehon perusteella määräytyvää alinta verotasoa. Ainakin purjeveneiden rungon pituuden voi olettaa jonkin verran korreloivan veneen arvoon. Koska veronalaisia purjeveneitä olisi suhteellisen vähän, verotaso olisi kuitenkin hallinnollisen yksinkertaisuuden takia kaikille sama.

Moottori- ja purjeveneen rungon pituuteen perustuva vero olisi toissijainen moottoritehon mukaan määräytyvään veroon nähden. Jos moottori- tai purjeveneestä kannettaisiin veroa moottoritehon mukaan, rungon pituuden perusteella määräytyvää veroa ei maksuunpantaisi.

\subsection{Verotusmenettely}

Ehdotuksen mukaan veron kantaisi Trafi, joka nykyisin ylläpitää vesikulkuneuvoista rekisteriä Manner-Suomessa. Verotus perustuisi lähtökohtaisesti rekisteritietoihin, ja verotusmenettelyssä noudatettaisiin pitkälti ajoneuvoverotuksessa sovellettavaa menettelyä.

Trafi kantaisi veron myös Ahvenanmaalla käytössä olevista vesikulkuneuvoista. Manner-Suomen ja Ahvenanmaan rekisteröintivelvoitteiden eroavaisuuksien takia verollisiksi säädettävien vesikulkuneuvojen omistajille säädettäisiin velvollisuus antaa vesikulkuneuvosta veroilmoitus Trafille veron maksuunpanoa varten. Ilmoitus annettaisiin vain silloin, kun vesikulkuneuvo otetaan käyttöön tai kun vesikulkuneuvon tiedot muuttuvat. Vesikulkuneuvon asianmu- 
2 Venevero hallitusohjelmassa 2015 ja valtiovarainministeriön...

kainen rekisteröinti venerekisteriin kuitenkin korvaisi veneestä tehtävän veroilmoituksen, jolloin verotus olisi mahdollista toteuttaa siten, että siitä on mahdollisimman vähän hallinnollista rasitetta veneiden omistajille.

Vaikka vero muodollisesti perustuisi tuohon veroilmoitukseen, käytännössä vero valtaosassa tapauksia kannettaisiin viranomaisaloitteisesti suoraan rekisteritietojen perusteella. Veronalaisten vesikulkuneuvojen veroilmoitus- ja venerekisteritiedot muodostaisivat veneveron perusteena käytettävän verorekisterin. Vero kannettaisiin niiden tietojen mukaan, jotka on merkitty tai olisi tullut merkitä rekisteriin taikka joista on annettu tai olisi tullut antaa veroilmoitus verokauden alkaessa.

Veneveroon ei vaikuttaisi kesken verokauden tapahtuva omistuksen tai hallinnan luovutus eikä myöskään vesikulkuneuvon poisto venerekisteristä, toisin kuin ajoneuvoihin sovellettavassa ajoneuvoverossa.

Vesikulkuneuvojen käyttö on hyvin kausiluonteista. Merenkulkulaitoksen tutkimuksen mukaan rekisteröintivelvoitteen alaisia perämoottorilla varustettuja veneitä käytettiin vain noin 20 tuntia vuodessa. Jos verotus perustuisi ajoneuvojen tavoin käyttöpäiviin, päiväkohtaisen veron määrä verolla tavoitellun vuotuisen verotuoton saavuttamiseksi muodostuisi erittäin suureksi.

Esityksessä todettiin, että korkealla, käyttöpäiviin perustuvalla verolla voisi olla veneilyä huomattavasti vähentäviä käyttäytymisvaikutuksia. Korkea päiväkohtainen vero voisi myös lisätä väärinkäytöksiä. Siten vero tulisi kantaa vuoden mittaiselta verokaudelta riippumatta siitä, kuinka paljon vesikulkuneuvoa verokauden aikana tosiasiassa käytetään. Jos vesikulkuneuvo olisi verokauden päättyessä poistettu rekisteristä ja vesiliikenteestä, siitä maksuunpantaisiin uudelleen veroa vasta siitä ajankohdasta, jona se on uudelleenrekisteröity. Vero maksuunpantaisiin vastaavasti, jos havaittaisiin, että vesikulkuneuvo on otettu käyttöön ilman vero- tai rekisteri-ilmoitusta.

Kalenterivuoden sijasta verokautena pidettäisiin liukuvaa 12 kuukauden jaksoa. Ensimmäinen verokausi alkaisi lain voimaantulopäivänä niille vesikulkuneuvoille, jotka silloin on merkitty rekisteriin. Rekisteriin myöhemmin merkittävien vesikulkuneuvojen verokausi alkaisi rekisterimerkinnästä. 
Trafi panisi veron maksuun verovelvolliselle lähetettävillä verolipuilla. Verovelvollinen olisi verokauden alkaessa vesikulkuneuvon rekisteriin merkitty omistaja tai haltija. Jos omistajia tai haltijoita on useita, he olisivat yhteisvastuussa veron suorittamisesta. Verolippu lähetettäisiin kuitenkin ensisijaisesti rekisteriin merkitylle yhteyshenkilölle tai, jos yhteyshenkilöä ei ole ilmoitettu, jollekin omistajista tai haltijoista. Vesikulkuneuvosta, josta on tehty venerekisterilakiin ehdotettava luovutusilmoitus, vero maksuunpantaisiin sille, jolle luovutus on tehty. Omistajan tai haltijan vaihdos kesken verokauden ei vaikuttaisi veron määrään, toisin kuin ajoneuvojen ajoneuvoverotuksessa. Maksettu vero seuraisi siten vesikulkuneuvon mukana uuden omistajan hyödyksi verokauden loppuun. Uuden verokauden alkaessa vero pantaisiin maksuun rekisteriin merkitylle uudelle omistajalle tai haltijalle.

Veroa valvoisivat Poliisi, Tulli ja Rajavartiolaitos. Koska valvontatilanteessa viranomaisilla ei välttämättä ole pääsyä rekisteritietoihin, verovelvollisen tai vesikulkuneuvon käyttäjän olisi esitettävä näyttö siitä, että vesikulkuneuvo on asianmukaisesti rekisteröity venerekisteriin tai että siitä on annettu veroilmoitus. Jos vesikulkuneuvoa käytettäisiin veroa suorittamatta, kannettaisiin sanktioluonteista lisäveroa, kuten ajoneuvoverotuksessa.

\subsection{Venerekisterilain muutokset}

Esityksessä ehdotettiin, että venerekisterilain säännöksiä rekisteröitävän vesikulkuneuvon teknisten tietojen ilmoittamisesta tarkennettaisiin, koska veron perusteena käytettäisiin ensisijaisesti vesikulkuneuvon konetehoa ja toissijaisesti vesikulkuneuvon pituutta. Lakiin lisättäisiin myös tarkemmat määrittelyt erilaisille rekisteriilmoituksille ja siten osaltaan varmistettaisiin kansalaisten oikeusturva esimerkiksi tilanteissa, joissa vesikulkuneuvo on luovutettu eteenpäin.

Vesikulkuneuvon pituus tulisi ilmoittaa vesikulkuneuvorekisteriin valmistajan ilmoituksen mukaan. Jos tällaista ilmoitusta ei olisi saatavilla, rungon suurimman pituuden mittaamiseen tulisi käyttää yhdenmukaistetun standardin mukaista mittaustapaa. Rekisteröintivelvollisuutta koskeviin poikkeuksiin lisättäisiin tarkennus kilpailu- 
2 Venevero hallitusohjelmassa 2015 ja valtiovarainministeriön...

käytöstä. Rekisteröintivelvollisuus ei koskisi yksinomaan veneily- tai purjehduskilpailukäytössä olevaa vesikulkuneuvoa. Kilpailukäytöllä ei tarkoitettaisi esimerkiksi kalastuskilpailuja.

Venerekisterilakiin lisättäisiin mahdollisuus merkitä vesikulkuneuvolle yhteyshenkilö, joka olisi automaattisesti verovelvollinen kyseisestä vesikulkuneuvosta. Yhteyshenkilön tulisi olla vesikulkuneuvon haltija ja/tai omistaja.

Muutosrekisteröinnin määräaikaa lyhennettäisiin 30 päivästä seitsemään kalenteripäivään, jotta rekisteri saataisiin mahdollisimman ajantasaiseksi sekä vältettäisiin virheellisesti maksuunpantuja veroja ja niiden oikaisutarvetta. Lisäksi edellytettäisiin kattavampien tietojen toimittamista vesikulkuneuvoon asennettavasta moottorista myös moottorin vaihdon yhteydessä; moottoriteho olisi veron ensisijainen peruste.

Lakiin lisättäisiin säännös vesiliikennekäytöstä poistosta ja vesiliikennekäyttöön otosta, joiden avulla verovelvolliselle annettaisiin mahdollisuus vapautua veron maksamisesta niiltä verokausilta, joina verovelvollinen ei käytä vesikulkuneuvoa.

Rekisteröintitapahtumiin lisättäisiin vesikulkuneuvon luovutusilmoitus, jotta vesikulkuneuvon luovuttanut henkilö voisi ilmoittaa luopuneensa vesikulkuneuvosta siinä tapauksessa, että luovutuksen saaja jättäisi rekisteri-ilmoituksen tekemättä. Myös vesikulkuneuvon haltijalla olisi jatkossa mahdollisuus ilmoittaa hallinnan päättymisestä Trafille. Lisäksi vesikulkuneuvon tai moottorin lopullista poistoa koskevaan ilmoitukseen liittyen esityksessä tarkennettaisiin, että lopullisesti poistettua vesikulkuneuvoa tai moottoria ei enää voitaisi rekisteröidä uudelleen venerekisteriin.

Vesikulkuneuvoista ja moottoreista tallennettaviin tietoihin lisättäisiin mahdollisuus tallentaa venekulkuneuvorekisteriin myös verotukseen liittyviä tietoja.

Esityksessä ehdotettiin myös muutettavaksi venerekisterilain rangaistussäännöksiä siten, että käyttökiellossa olevan veneveron alaisen vesikulkuneuvon käyttämisestä ei rangaistaisi silloin kun samasta teosta märätään myös veneverolain mukainen hallinnollinen seuraamus lisäverona. Kyseisellä menettelyllä varmistettaisiin, että samaa henkilöä ei rangaista samasta teosta kahdesti. 


\subsection{Taloudelliset vaikutukset}

Esityksessä todettiin, että venerekisterissä nyt olevien vesikulkuneuvojen lukumäärän perusteella veroa kertyisi noin 19 miljoonaa euroa vuodessa vuodesta 2017 alkaen. Tuotosta vajaat miljoona euroa kertyisi purjeveneistä. Verotuoton arvioitiin kuitenkin jäävän pienemmäksi, koska oli oletettavaa, että vesikulkuneuvoja tullaan jättämään rekisteröimättä tai poistamaan venerekisteristä veron välttämistarkoituksessa.

Esityksen mukaan vesikulkuneuvo voitaisiin myös laillisesti poistaa vesiliikennekäytöstä, jolloin siitä ei tarvitsisi maksaa veroa seuraavilta verokausilta. Lisäksi moottorin vaihtaminen veronmaksuvelvollisuuden alarajaa pienemmäksi poistaisi vesikulkuneuvon veron piiristä. Jos oletetaan, että rekisteristä tai muuten veron alaisuudesta poistuisi esimerkiksi $10 \%$ vesikulkuneuvoista, vuotuinen verotuotto jäisi 17 miljoonaan euroon. Oletusta $10 \%$ :n rekisteripoistumasta voitiin pitää varovaisena arviona, joten verotuotto saattaisi jäädä ennustettua alhaisemmaksi. Aktiivisesti käytössä olevien veneiden määrää jossain määrin kuvaa vakuutettujen veneiden määrä, joka vuonna 2015 oli noin 171000 . Tämä oli vain runsaat $80 \%$ rekisteröityjen veneiden määrästä.

Esityksessä todettiin, että lisäksi veron periminen 12 kuukauden liukuvalta jaksolta saattaa osaltaan vähentää verotuottoa. Mahdollisesti joidenkin veneiden osalta veroa ei tulisi kannetuksi jokaisena kalenterivuotena, vaikka venettä käytettäisiin joka vuosi. Kun otetaan huomioon veneiden vähäinen käyttömäärä, voisi olla mahdollista ajoittaa veneiden käyttö siihen ajankohtaan, jolloin edellisenä kalenterivuonna alkanut verokausi ei ole vielä päättynyt. Tällä voisi olla pieni vaikutus veneveron tuottoon.

Venevero vähentäisi kotitalouksien käytettävissä olevia tuloja, minkä esityksessä arvioitiin vähentävän arvonlisäverokertymää noin kaksi miljoonaa euroa vuodessa olettaen, että kotitalouksien kulutus vähenisi veron määrän verran.

Ehdotettu vero koskisi noin puolta rekisteröidyistä vesikulkuneuvoista. Moottoritehoon perustuvan veron määrä vaihtelisi 100 ja 300 euron välillä. Mediaanivero olisi 175 euroa vuodessa. Suurin veron 
2 Venevero hallitusohjelmassa 2015 ja valtiovarainministeriön...

määrä eli 300 euroa kannettaisiin noin 10 prosentilta rekisteröidyistä veneistä.

Veron piiriin tulevista vesikulkuneuvoista noin puolet olisi perämoottoriveneitä. Tyypillisesti niiden hinta uutena oli arviolta 12 000-100 000 euroa. Sisä- tai sisäperämoottoriveneiden hinta uutena vaihteli arviolta 50 000-130 000 euron välillä. Uusien veneiden kauppa oli kuitenkin melko vähäistä venekantaan suhteutettuna. Vesikulkuneuvoja oli ensirekisteröity 2010-luvulla 3 500-5 200 kappaletta vuodessa. Keskimäärin veneitä rekisteröitiin vuosittain noin 900 vähemmän kuin vielä 2000-luvun alkupuolella. Osaltaan tämä selittyi yleisen taloudellisen tilanteen heikentymisellä. Käytettyjä veneitä myytiin vuosittain arviolta 15 000-20 000. Niiden keskihinta oli 7 000-8 000 euroa. Venerekisterin mukaan veneiden keski-ikä on 23 vuotta. Venekanta on siten varsin iäkästä ja myös melko vähäarvoista.

Veneilyn vuosittaiset kustannukset vaihtelevat huomattavasti. Veneilijöille tehdyn kyselyn perusteella aktiivisesti veneilyä harrastavien veneiden vuosittaiset käyttökustannukset voivat olla noin 2500 euroa, mutta useimmilla veneilijöillä kustannukset jäänevät selvästi tätä alhaisemmaksi. Veneveron määrää voi suhteuttaa esimerkiksi keskimääräiseen veneiden vakuutusmaksuun, joka oli 170 euroa vuonna 2015.

Esityksen mukaan rekisterissä olevista vesikulkuneuvoista vero kannettaisiin vuoden pituiselta jaksolta riippumatta siitä, kuinka paljon niitä käytetään vesiliikenteeseen. Vesikulkuneuvojen käyttö on vahvasti kausiluonteista, joten käyttöpäiviin suhteutettuna veron määrä olisi suhteellisen korkea. Esimerkiksi autojen ajoneuvovero on päivää kohden keskimäärin 0,67 euroa. Veneilyä harrastetaan keskimäärin 6-15 päivänä vuodessa, joten venevero olisi 7-50 euroa päivältä eli monenkertainen autojen veroon verrattuna. Ajoneuvoverossa mahdollisen kaltainen verokauden keskeyttäminen liikennekäytöstä poistolla ei olisi vesikulkuneuvojen osalta mahdollinen. Verolta välttyisi vain, jos vesikulkuneuvo olisi poistettuna vesiliikenteestä verokauden alkaessa.

Vero koskisi myös niitä viranomaisten käytössä olevia vesikulkuneuvoja, jotka ovat rekisterissä. Tämä lisäisi jonkin verran viranomaisten kustannuksia. Lisäksi veron piiriin tulisivat esimerkiksi 
pelastustoimintaan meri- ja järvialueilla käytettävät pelastusveneet, joten vero lisäisi myös vapaaehtoisen pelastustoiminnan kustannuksia. Yhteensä edellä mainittuja veneitä arvioidaan olevan yli 1000.

\subsection{Yritysvaikutukset}

Suomessa veneiden valmistuksessa, korjaustoiminnassa ja vuokrauksessa sekä veneiden ja niiden varaosien ja tarvikkeiden tukku- ja vähittäiskaupassa toimii Tilastokeskuksen mukaan vajaat 800 yritystä, joiden yhteenlaskettu liikevaihto on runsaat 600 miljoonaa euroa ja jotka työllistävät yhteensä noin 3000 ihmistä. Suomalaisen venevalmistuksen arvosta noin $70 \%$ menee vientiin. Veneiden viennin arvo oli ulkomaankauppatilastojen mukaan noin 190 miljoonaa euroa vuonna 2015, ja kotimaan myynnin arvo oli alan tietojen perusteella noin 80 miljoonaa euroa.

Veneilyyn liittyvät matkailupalvelut esimerkiksi vierasvenesatamissa tuovat lisätuloja myös niille rannikon, saaristomeren ja sisävesien kunnille, joihin matkaveneily kohdistuu voimakkaimmin. Veron käyttöönotto voisi vähentää uusien veneiden myyntiä tai siirtää veneiden hankintaa pienempiin ja edullisempiin veneisiin. Vero lisäisi veneilyn kustannuksia, joten sillä voisi olla vaikutusta veneilyn määrään ja veneilyyn liittyvien oheispalveluiden käyttöön. Lisäksi veneilyn vähentymisen ja veneiden mahdollisen hinnanlaskun seurauksena kauppiaiden myynti- ja vaihtovarastoissa olevien veneiden arvo saattaisi jossain märin laskea. Esityksessä todettiin, että veron käyttöönotto voisi siten johtaa venealan kannattavuuden ja yleisten toimintamahdollisuuksien lievään heikentymiseen ja jopa työpaikkojen menetykseen.

\subsection{Ympäristövaikutukset}

Esityksessä todettiin, että veneilyn lähiympäristössä ilmeneviä ympäristövaikutuksia ovat esimerkiksi meluhaitat, roskaaminen ja pakokaasuyhdisteet. Lisäksi veteen pääsevät öljyt ja jätteet sekä 
2 Venevero hallitusohjelmassa 2015 ja valtiovarainministeriön...

veneenpohjien maalauksessa käytettävät myrkylliset maalit muodostavat haitan ympäristölle. Huviveneliikenteen ilmastomuutokseen vaikuttavat hiilidioksidipäästöt olivat vuonna 2015 noin 130000 tonnia, joka määrä sisälsi myös veneveron ulkopuolelle jäävien huviveneiden päästöt. Kotimaan vesiliikenteen kokonaishiilidioksidipäästöt olivat noin 440000 tonnia ja ulkomaan vesiliikenteen päästöt Suomen talousalueella noin 2,3 miljoonaa tonnia.

Merenkulkulaitoksen vuonna 2005 julkaisemassa tutkimuksessa huviveneilyn päästöistä arvioitiin aiheutuvan yhteensä noin 10 miljoonan euron suuruiset taloudelliset haitat vuodessa. Merkittävin osatekijä arviossa oli ilmastonmuutokselle annettu painoarvo. Loput päästökustannukset olivat seurausta terveydelle ja luonnolle aiheutuvista haitoista. Veneilyn päästöjen osuus Suomen liikenteen päästökustannuksista oli kuitenkin hyvin pieni.

Venevero olisi esityksen mukaan tavoitteeltaan valtiontaloudellinen eikä ympäristönäkökohtiin perustuva. Tästä huolimatta veron pääasiallisena perusteena olevan moottoritehon voi katsoa yleisellä tasolla liittyvän polttoaineen kulutukseen ja siten veneen ominaishiilidioksidipäästöihin. Jos veneilysuoritteen määrä veneveron takia alenee, tällä voi olla vähäinen vaikutus veneilyn ympäristöhaittojen vähenemiseen.

\subsection{Vaikutukset viranomaistoimintaan}

Veron kantaisi Trafi, joka pitää venerekisteriä Manner-Suomessa. Uuden veron käyttöönotto edellyttää Trafin tietojärjestelmiin kertaluonteisia muutoksia. Kertaluonteista lisätyötä aiheutuisi myös asiakkaiden opastamisesta sekä ohjeistuksen ja lomakkeiden laatimisesta, joka vaatisi ensimmäisenä vuonna arviolta yhden henkilötyövuoden. Trafi sai valtion vuoden 2017 talousarvioesityksen yhteydessä lisärahoitusta vuodelle 2017 veneveron ja kevyiden moottoriajoneuvojen veron kustannuksiin miljoona euroa. Tästä summasta pääosa kuluisi tietojärjestelmätyöhön.

Esityksessä veneveron vuotuisten veronkantokustannusten arvioitiin olevan joitakin satojatuhansia euroja. Venerekisterilakiin ehdotetut muutokset vaatisivat joitakin muutoksia sekä nykyisen 
vesikulkuneuvorekisterin käytäntöihin että järjestelmiin, erityisesti uusien rekisteri-ilmoitusten käyttöönoton myötä.

Veroa valvoisivat Poliisi, Tulli ja Rajavartiolaitos. Valvontaa toteutettaisiin lähinnä näiden viranomaisten muiden valvontatoimenpiteiden yhteydessä.

\subsection{Yhteiskunnalliset vaikutukset}

Veron käyttöönoton ja venerekisterilain muutosten arvioitiin johtavan ajan myötä venerekisterin tietojen nykyistä tehokkaampaan päivittymiseen. Tällä olisi positiivisia vaikutuksia rekisterin käyttökelpoisuuteen erityisesti vesiliikenneturvallisuustarkoitukseen, johon se on alun perin säädetty.

Toisaalta vero voi merkitä vesikulkuneuvojen poistoa rekisteristä veron välttämistarkoituksessa, koska vesiliikenteen valvontamahdollisuudet erityisesti sisävesillä ovat vähäiset. Veroa voitaisiin myös pyrkiä kiertämään vaihtamalla tai poistamalla moottorin tehomerkinnät. Jos vesikulkuneuvojen verotus saisi aikaan vesikulkuneuvojen aiheetonta poistamista venerekisteristä, olisi mahdollista, että rekisterin tietosisällön luotettavuus kärsisi eikä rekisteriä voitaisi enää pitää luotettavana tilastoinnin työkaluna. Sanktioksi ehdotetulla lisäverolla pyrittäisiin kuitenkin vähentämään väärinkäytöksiä.

Esityksen mukaan venerekisterin ja verotusaineiston perusteella arvioiden veneiden omistus on selvästi yleisempää ylemmissä tuloluokissa. Veron piiriin kuuluvista veneistä lähes $60 \%$ kuuluu kahteen ylimpään tulokymmenykseen lukeutuville omistajille, ja yli $80 \%$ veneiden omistajista kuuluu hyvätuloisempaan puoliskoon väestöstä, kun tuloluokkien rajat on laskettu yli 18-vuotiaan väestön tulojen mukaan.

Verotusaineistolla ei kuitenkaan voida muodostaa selkeitä kotitalouksia, joista tulonjakovaikutusarvioissa tavanomaisesti käytettyä Gini-indikaattoria lasketaan. Tilastokeskuksen kulutustutkimuksessa nämä tiedot ovat saatavilla, mutta aineisto on haastatteluluonteensa johdosta epätarkempi ja sisältää runsaasti myös muita kuin veron piiriin ehdotettavaksi kuuluvia veneitä. Kulutustutkimuksen aineistosta ilmenee kuitenkin verotusaineiston tapaan, että moottori- ja 
2 Venevero hallitusohjelmassa 2015 ja valtiovarainministeriön...

purjeveneiden omistus on selvästi yleisempää ylemmissä tuloluokissa. Ylimmän tulokymmenyksen kotitalouksilla veneiden omistus on yli kaksi kertaa yleisempää kuin kotitalouksilla keskimäärin ja lähes kymmenen kertaa yleisempää kuin alimman tulokymmenyksen kotitalouksilla.

Ehdotetun veromuutoksen vaikutus Gini-kertoimella mitattuna olisi kulutustutkimuksen aineistosta laskettuna vähemmän kuin $-0,01$. Vaikka lukuun liittyy epävarmuuksia, se kuvaa kohtuullisella tavalla muutoksen suuntaa ja vaikutuksen kokoa. Vaikutus olisi siis mittaluokaltaan varsin pieni mutta progressiivinen eli suurituloisiin kotitalouksiin voimakkaammin kohdentuva. Vaikutuksen vaimeus johtuu enemmän veron taloudellisen vaikutuksen pienuudesta kuin vaikutuksen kohdentumisesta.

\subsection{Lakitekstiehdotus}

Säädöstekstiehdotus veneverolaiksi oli seuraava:

\section{$1 \int$ Lain soveltamisala}

Suomessa vesiliikenteessä käytettävistä vesikulkuneuvoista on suoritettava valtiolle veneveroa siten kuin tässä laissa säädetään.

Vesikulkuneuvoa katsotaan käytettävän vesiliikenteessä, jos sillä liikutaan tai sitä muuten pidetään vesistössä.

\section{$2 \int$ Veronalaiset vesikulkuneuvot}

Veronalaisia ovat vesikulkuneuvot, joiden moottorin tai moottoreiden yhteenlaskettu teho on valmistajan ilmoituksen mukaan vähintään 38 kilowattia sekä vesikulkuneuvot, joiden rungon pituus on valmistajan ilmoituksen mukaan vähintään yhdeksän metriä.

Veronalaisina ei kuitenkaan pidetä vesikulkuneuvoja, jotka on vapautettu rekisteröintivelvollisuudesta vesikulkuneuvorekisteristä annetun lain (424/2014) 2 \$:n 2 momentin, 4 \$:n, 5 \$:n 2 momentin tai 13 \$:n perusteella eikä vastaavin perustein Ahvenanmaalla vakituisesti käytettäviä vesikulkuneuvoja.

Tässä laissa tarkoitetaan vesikulkuneuvolla veteen tukeutuvaa ja vesillä liikkumiseen tarkoitettua kulkuvälinettä ja laitetta. Rungon pituudella tarkoitetaan vesikulkuneuvorekisteristä annetun lain 3 \$:n mukaisesti rekisteriin merkittyä pituutta. 


\section{S Ilmoittamisvelvollisuus}

Vesikulkuneuvon omistaja on velvollinen tekemään Liikenteen turvallisuusvirastolle veroilmoituksen Suomessa vesiliikenteessä käytettävästä veronalaisesta vesikulkuneuvosta. Jos vesikulkuneuvo on muun kuin omistajan hallinnassa, haltija on velvollinen tekemään veroilmoituksen. Ilmoitus on tehtävä ennen kuin vesikulkuneuvo otetaan ensimmäisen kerran käyttöön Suomessa.

Veroilmoitusta ei kuitenkaan tarvitse tehdä niistä vesikulkuneuvoista, jotka on rekisteröity vesikulkuneuvorekisteristä annetun lain mukaisesti.

Edellä 1 momentissa tarkoitetun veroilmoituksen tulee sisältää selvitys:

1) vesikulkuneuvon omistajasta, haltijasta ja yhteyshenkilöstä;

2) vesikulkuneuvon ja sen moottorin yksilöinti- ja teknisistä tiedoista; sekä

3) vesikulkuneuvon käyttötarkoituksesta ja sen pääasiallisesta käyttökunnasta.

Liikenteen turvallisuusvirasto voi antaa tarkempia määräyksiä verotusta varten ilmoitettavista tiedoista, tietojenantotavasta ja muusta veroilmoittamisen menettelystä.

\section{$4 \int$ Muutoksista ilmoittaminen}

Vesikulkuneuvon omistaja tai haltija on velvollinen ilmoittamaan 3 \$:n 3 momentissa mainittujen tietojen muutoksista Liikenteen turvallisuusvirastolle, jos vesikulkuneuvoa ei ole rekisteröity vesikulkuneuvorekisteristä annetun lain mukaisesti. Lisäksi Liikenteen turvallisuusvirastolle on ilmoitettava, jos tällaisen vesikulkuneuvon käyttö vesiliikenteessä lopetetaan tai käytöstä poistettu vesikulkuneuvo otetaan uudelleen käyttöön.

Vesikulkuneuvon edellinen omistaja tai haltija voi ilmoittaa vesikulkuneuvon luovutuksesta tai hallinnan päättymisestä kuten vesikulkuneuvorekisteristä annetun lain 9 b ja 9 c $\$$ :ssä säädetään. Ilmoitus on annettava ennen kuin vesikulkuneuvoa muutoksen jälkeen käytetään vesiliikenteessä, kuitenkin viimeistään seitsemäntenä päivänä muutoksesta.

Omistajan tai haltijan on ilmoitettava Liikenteen turvallisuusvirastolle seitsemän päivän kuluessa vesikulkuneuvon tai sen moottorin lopullisesta tuhoutumisesta, romuttamisesta tai purkamisesta sekä esitettävä asiasta luotettava selvitys.

Liikenteen turvallisuusvirasto voi antaa tarkempia määräyksiä muutosilmoitusten tiedoista, tietojenantotavasta ja muusta ilmoittamisen menettelystä.

\section{$5 \int$ Verorekisteri}

Liikenteen turvallisuusvirasto pitää veneveron kantamista ja valvontaa varten rekisteriä veronalaista vesikulkuneuvoista (verorekisteri). Rekisteri koostuu vesikulkuneuvorekisteristä annetun lain perusteella rekisteröityjen veronalaisten vesikulkuneuvojen rekisteritiedosta, edellä 3 ja 4 \$:n mukaan 
2 Venevero hallitusohjelmassa 2015 ja valtiovarainministeriön...

annetuista veroilmoitustiedoista sekä Liikenteen turvallisuusviraston muuten rekisteriin merkitsemien veronalaisten vesikulkuneuvojen tiedoista.

Jollei tässä laissa toisin säädetä, verorekisterin tietosisältöön, rekisteritietojen korjaamiseen, tietojen luovuttamiseen ja Liikenteen turvallisuusviraston tiedonsaantioikeuteen sovelletaan soveltuvin osin, mitä vesikulkuneuvorekisteristä annetun lain 14-21 \$:ssä säädetään.

Liikenteen turvallisuusvirasto voi antaa verorekisteriin merkityille vesikulkuneuvoille verotunnuksen. Verotunnuksen antamiseen ja käyttöön sovelletaan, mitä vesikulkuneuvorekisteristä annetun lain 12-13 \$:ssä säädetään rekisteritunnuksesta ja koetunnuksesta.

\section{$6 \int$ Verokausi}

Vero kannetaan 12 kuukauden jaksolta.

Verokausi alkaa, kun vesikulkuneuvosta annetaan veroilmoitus tai kun vesikulkuneuvo merkitään verorekisteriin, kuitenkin viimeistään kun vesikulkuneuvoa aletaan käyttää vesiliikenteessä. Seuraava verokausi alkaa edellisen verokauden päättymistä seuraavana päivänä, jos verovelvollisuus vesikulkuneuvosta ei ole päättynyt 10 \$:n 4 momentin mukaan.

\section{S Veron määräytymisen ajankohta}

Vero kannetaan niiden tietojen mukaan, jotka on merkitty tai olisi pitänyt olla ilmoitettu verorekisteriin verokauden alkaessa.

Jos vesikulkuneuvon moottorin teho on verokauden aikana suurempi kuin verokauden alkaessa, kannetaan vero koko verokaudelta uuden tehon mukaan. Maksuunpantavasta verosta vähennetään verokaudelta aikaisemmin maksuunpantu vero.

\section{$8 \int$ Veron mä̈̈rä}

Vesikulkuneuvosta, jonka moottorin teho tai moottoreiden yhteenlaskettu teho on vähintään 38 kilowattia, on suoritettava veneveroa liitteen verotaulukon mukaan. Veneveron määrä muista veronalaisista vesikulkuneuvoista on 100 euroa.

Venevero kannetaan koko verokaudelta riippumatta siitä, onko vesikulkuneuvo käytössä tai käytettävissä koko verokautta.

9 S Lisävero rekisteröimättömän tai käytöstä poistetuksi ilmoitetun vesikulkuneuvon käyttämisestä vesiliikenteeseen

Jos vesiliikenteessä käytetään rekisteröimätöntä tai käytöstä poistetuksi ilmoitettua vesikulkuneuvoa, josta ei ole kannettu veroa $6 \$$ :n mukaisesti, verokaudelta maksuunpantavan veron lisäksi kannetaan lisäveroa. Lisäveron määrä on verokaudelta laskettava venevero viisinkertaisena.

Lisävero määrätään sen maksettavaksi, joka on vesikulkuneuvosta verovelvollinen. Lisävero määrätään noudattaen ajoneuvoverolain (1281/2003) 47 §:ssä säädettyä jälkiverotusmenettelyä. 


\section{$10 \$$ Verovelvollisuus}

Veneveron on velvollinen suorittamaan verokauden alkaessa verorekisteriin merkitty vesikulkuneuvon omistaja tai haltija taikka se, jolle vesikulkuneuvo on luovutettu.

Jos verorekisteriin on merkitty sekä omistaja että haltija, haltija on verovelvollinen. Jos vesikulkuneuvon omistaja tai haltija on ilmoitettu yhteyshenkilöksi, myös yhteyshenkilö on verovelvollinen.

Jos verovelvollisia on enemmän kuin yksi, he ovat yhteisvastuussa veron suorittamisesta Jos vesiliikenteessä käytetään rekisteröimätöntä tai rekisteristä poistettua vesikulkuneuvoa tai verorekisteriin merkitty tieto on virheellinen, verovelvollinen on se, joka on velvollinen antamaan veroilmoituksen tai joka tulisi olla merkittynä verorekisteriin vesikulkuneuvon omistajaksi tai haltijaksi. Jollei omistajaa tai haltijaa voida osoittaa tai jos käytöstä poistetuksi ilmoitettua, rekisteristä poistettua tai rekisteröimätöntä vesikulkuneuvoa on käytetty omistajan tai haltijan suostumuksetta, eikä vesikulkuneuvosta ole kannettu 1 momentin mukaisesti veroa verokaudelta, verovelvollinen on se, jonka käytössä vesikulkuneuvon on katsottava olleen.

Verovelvollisuus päätyy sen verokauden päättyessä, jonka aikana:

1) vesikulkuneuvo on poistettu rekisteristä tai ilmoitettu käytöstä poistetuksi ja sen käyttö vesiliikenteessä on lakannut;

2) vesikulkuneuvoon tehdyn muutoksen takia sen veronalaisuus on lakannut;

3) vesikulkuneuvon omistaja- tai haltijatieto muuttuu siten, että seuraavalle verokaudelle vero on maksuunpantava uudelle verovelvolliselle; tai

4) vesikulkuneuvo on ilmoitettu anastetuksi, edellyttäen, että tätä koskeva rekisterimerkintä on voimassa verokauden viimeisenä päivänä.

\section{S Veron maksuunpano yhteisvastuullisille verovelvollisille}

Yhteisvastuullisista verovelvollisista vero maksuunpannaan vesikulkuneuvon yhteyshenkilöksi merkitylle haltijalle tai omistajalle. Jos yhteyshenkilöä ei ole merkitty verorekisteriin, vero maksuunpannaan haltijalle tai omistajalle. Jos veroa ei saada perittyä henkilöltä, jolle se on maksuunpantu, vero voidaan maksuunpanna muulle yhteisvastuulliselle verovelvolliselle.

\section{S Viranomaiset}

Liikenteen turvallisuusvirasto vastaa verotuksen toimittamisesta, veronkannosta, verovalvonnasta ja muista tässä laissa säädetyistä viranomaistehtävistä, jollei tässä laissa toisin säädetä. Lisäksi Ahvenanmaan valtiovirasto hoitaa ajoneuvoverolain 56 \$:n 3 momentissa tarkoitettuja avustavia tehtäviä Ahvenanmaalla veneveron osalta.

Tulli, poliisi ja Rajavartiolaitos valvovat veron suorittamista ja oikeellisuutta.

Valtion etua valvoo muutoksenhakua ja oikaisua koskevissa asioissa Liikenteen turvallisuusviraston veroasiamies. 
2 Venevero hallitusohjelmassa 2015 ja valtiovarainministeriön...

\section{$13 \int$ Rekisteröinnin todentaminen}

Verovelvollisen tai vesikulkuneuvon käyttäjän on valvontatilanteessa esitettävä näyttö siitä, että vesikulkuneuvo on asianmukaisesti merkitty verorekisteriin.

\section{S Veneveroa koskevien tietojen julkisuus}

Veneveroa koskevat tiedot ovat julkisia lukuun ottamatta veronhuojennus- ja lykkäyspäätöksiä niihin liittyvine asiakirjoineen. Veneveroa, vesikulkuneuvoa sekä verovelvollista koskevien tietojen julkisuuteen ja tietojen luovuttamiseen sovelletaan lisäksi, mitä vesikulkuneuvorekisteristä annetun lain 22-27 §:ssä säädetään.

\section{S Eräiden lakien soveltaminen}

Jollei tässä laissa toisin säädetä, sovelletaan veneveron kantoon, perintään, ennakkoratkaisuun, veronkorotukseen, jälkiverotukseen, oikaisuun, muutoksenhakuun, avustaviin tehtäviin, tekniseen valvontaan, veronkiertoon, veronhuojennukseen, pienimpään perittävään, maksuunpantavaan ja palautettavaan määrän sekä sähköiseen allekirjoitukseen, mitä ajoneuvoverolain 15, 22-25, 45-47, 48-52, 56 \$:n 3 momentissa, 57 \$:n 2 momentissa, 60-62 ja 65 \$:ssä säädetään ajoneuvoverosta. Siltä osin kuin tässä laissa tai 1 momentissa mainituissa ajoneuvoverolain säännöksissä ei toisin säädetä, sovelletaan veneveroon soveltuvin osin, mitä veronkantolaissa (609/2005) tai sen nojalla säädetään, samoin kuin mitä veronlisäyksestä ja viivekorosta annetussa laissa (1556/1995) sekä verojen ja maksujen täytäntöönpanosta annetussa laissa (706/2007) säädetään.

\section{S Rangaistussäännökset}

Rangaistuksesta veneveron lainvastaisesta välttämisestä ja sen yrittämisestä säädetään rikoslain (39/1889) 29 luvun 1-3 \$:ssä.

Viranomaisen tulee jättää rikosilmoitus tekemättä, esitutkinta toimittamatta, syyte ajamatta ja rangaistus määräämättä, jos vesiliikenteessä käytetään vesikulkuneuvoa, joka on rekisteröimätön, rekisteristä poistettu tai käytöstä poistetuksi ilmoitettu. Asiasta tulee ilmoittaa Liikenteen turvallisuusvirastolle.

\section{7 \& Voimaantulo}

Tämä laki tulee voimaan päivänä kuuta 20 .

Lain 3 \$:n 1 momentissa tarkoitettu veroilmoitus vesikulkuneuvoista, jotka on otettu käyttöön ennen lain voimaantuloa, tulee antaa viimeistään 1 päivänä kesäkuuta 2017. 


\section{3 \\ Veneverosta annetut lausunnot}

\subsection{Pyydetyt ja pyytämättä annetut lausunnot}

Valtiovarainministeriö pyysi 16.12.2016 veneveroesityksestä lausunnon seuraavilta seitsemältä taholta: liikenne- ja viestintäministeriö, oikeusministeriö, Poliisihallitus, Rajavartiolaitos, Venealan Keskusliitto Finnboat ry, Suomen Purjehdus ja Veneily ry ja Veronmaksajain Keskusliitto ry. Ne kaikki antoivat lausunnon. Ministeriölle saapui lisäksi pyytämättä lähes 70 muuta lausuntoa. Suurin osa lausunnoista löytyy netistä valtioneuvoston kotisivulta.

Seuraavassa selostetaan sekä pyydettyjä että pyytämättä toimitettuja lausuntoja. Kaikkia lausuntoja on tässä lyhennetty ja muutenkin jonkin verran muokattu erityisesti toiston vähentämiseksi. Aluksi käsitellään ministeriöiden ja valtion keskusvirastojen kannanottoja. Laajimmin ovat esillä venealan järjestöjen lausunnot. Perusteellisin ja monipuolisin on Venealan Keskusliitto Finnboat ry:n kannanotto, jolle myös seuraavassa annetaan eniten tilaa. 


\subsection{Liikenne- ja viestintäministeriö}

Liikenne- ja viestintäministeriö piti esityksen tavoitteita perusteltuina ja puolsi ajoneuvorekisterin kanssa mahdollisimman yhdenmukaista lainsäädäntöteknistä ratkaisua. Veneverorekisterin perustaminen olisi perusteltua yhdenmukaisen veronkannon mahdollistamiseksi, koska Ahvenanmaalla käytettäviä veneitä ei voida rekisteröidä mannermaan rekisteriin veronkantoa varten. Käytännössä Manner-Suomen venerekisteri toimisi verotuksen pohjana mannermaalla ja uusi veneverorekisteri toimisi Ahvenanmaalla.

Ministeriö kiinnitti huomiota alaisensa Trafin lisääntyviin uusiin viranomaistehtäviin ja kasvavaan hallinnolliseen taakkaan sekä siihen, että virastolle aiheutuu lisämäärärahatarpeita, jotka tulee kokonaisuudessaan ottaa huomioon viraston toimintamenomäärärahan mitoituksessa.

Kaksoisrangaistavuuden kieltoa koskevalta osalta ministeriö kiinnitti huomiota Euroopan ihmisoikeustuomioistuimen suuren jaoston 15.11.2016 antamaan ratkaisuun Norjaa koskevassa ne bis in idem -tapauksessa. Tuomioistuin ei pitänyt ongelmallisena sitä, että Norjassa samasta teosta seuraa sekä rikossyyte että veronkorotus. Ratkaisu poikkesi merkittävästi aikaisemmasta ihmisoikeustuomioistuimen tulkintakäytännöstä.

\subsection{Oikeusministeriö}

Perustuslain 81.1 §:n mukaan valtion verosta tulee säätää lailla, joka sisältää säännökset verovelvollisuuden ja veron suuruuden perusteista sekä verovelvollisen oikeusturvasta. Valtion veroa koskevasta laista tulee yksiselitteisesti ilmetä verovelvollisuuden piiri. Lain säännösten tulee olla niin tarkkoja, että lakia soveltavien viranomaisten harkinta veroa määrättäessä on sidottua harkintaa. Epäselvältä ehdotuksessa vaikutti, miten Suomen vesiliikenteessä vierailevat vesikulkuneuvot (esim. purjevene Virosta tai Helsingissä vieraileva risteilyalus) huomioidaan verotuksessa. Tulisiko niistä tehdä veroilmoitus, koska vero koskee Suomessa tapahtuvaa vesikulkuneuvojen käyttöä ja Suomen 
vesiliikenteessä käytettävästä veronalaisesta vesikulkuneuvosta ilmoitus olisi tehtävä? Ehdotuksesta ei ilmene perustuslain 81.1 \$:n edellyttämällä tavalla yksiselitteisesti verovelvollisuuden piiri.

Ehdotuksessa viitataan muun muassa avustavien tehtävien osalta ajoneuvoverolain 56.3 \$:ään, jonka mukaan veronkantoviranomainen voi tehdä sopimuksen veronkantoon liittyvän avustavan puhelinpalvelun siirtämisestä muun kuin viranomaisen hoidettavaksi. Perustuslain $124 \$: n$ arviointi avustavien tehtävien osalta on tässä kuitattu viittaamalla mainittuun ajoneuvoverolain säännökseen.

Esityksen mukaan Trafi voi antaa tarkempia määräyksiä verotusta varten ilmoitettavista tiedoista, tietojenantotavasta ja muusta veroilmoittamisen menettelystä. Trafin valtuuksia on arvioitava perustuslain 80.2 \$:n kannalta. Sen mukaan muu kuin perustuslain 80.1 \$:ssä mainittu asetuksenantaja voidaan lailla valtuuttaa antamaan oikeussääntöjä määrätyistä asioista, jos siihen on sääntelyn kohteeseen liittyviä erityisiä syitä eikä sääntelyn asiallinen merkitys edellytä, että asiasta säädetään lailla tai asetuksella. Tällaisen valtuutuksen tulee olla soveltamisalaltaan täsmällisesti rajattu. Asetuksenantovaltuuksiin verrattuna tällaisiin valtuuksiin kohdistuu yleistä tarkkarajaisuutta koskeva pidemmälle menevä vaatimus, jonka mukaan valtuuden kattamat asiat on määriteltävä tarkasti laissa. Olisi tarkasteltava, miltä osin määräykset voivat olla viranomaisen antamia määräyksiä ja pitäisikö osa niistä ehkä olla ministeriön asetuksessa.

Verovelvollisuus päättyisi sen verokauden päättyessä, jonka aikana kulkuneuvo on ilmoitettu anastetuksi, edellyttäen, että anastusta koskeva rekisterimerkintä on voimassa verokauden viimeisenä päivänä. Näin mikäli vene varastetaan verokauden viimeisinä päivinä mutta rekisterimerkintä tästä tulee voimaan vasta seuraavan verokauden ensimmäisenä päivänä, varastetun veneen omistaja on velvollinen maksamaan veneveron seuraavalta 12 kuukauden verokaudelta.

Ehdotetun veneverolain mukaan Trafi voi antaa verorekisteriin merkityille kulkuneuvoille verotunnuksen. Säännöksen muotoilu viittaa siihen, että Trafi käyttää harkintavaltaansa siinä, antaako se verotunnuksen vai ei. Ei ole tuotu esiin, missä tilanteissa Trafi ei antaisi verotunnusta.

Ahvenanmaan itsehallintolain nojalla valtionverot ovat valtakunnan lainsäädäntövaltaan kuuluvia asioita. Veneverolaki tulisi siten 
voimaan myös Ahvenanmaalla. Ahvenanmaan maakunnalla on itsehallintolain mukaan lainsäädäntövaltaa asioissa, jotka koskevat muun muassa veneliikennettä. Tältä osin maakunnan viranomaiset ylläpitävät huvivenerekisteriä. Veneverotus toteutettaisiin säätämällä kaikille verovelvollisille ilmoitusvelvollisuus ennen kuin venekulkuneuvo otetaan käyttöön. Menettelyn osasyynä on se, että Ahvenanmaalla maakunnan huvivenerekisteritiedot eivät kata kaikkia niitä venetyyppejä, jotka on valtakunnassa säädetty rekisteröitäviksi. Ilmoitusvelvollisuudesta vapautettuja olisivat kuitenkin niiden verovelvollisten venekulkuneuvot, jotka on rekisteröity valtakunnan venekulkuneuvorekisteriin.

Veneverolailla ei siis ehdoteta ahvenanmaalaiselle verovelvolliselle esimerkiksi erillistä velvoitetta rekisteröidä veneverotuksen piiriin kuuluva vene maakunnan tai valtakunnan venerekisteriin, eikä maakunnan viranomaisille säädettäisi velvollisuutta ilmoittaa verottajalle maakunnan huvivenerekisteritietoja. Koska sääntely ei siten puuttuisi maakunnan lainsäädäntövaltaan säätää esimerkiksi Ahvenanmaalla rekisteröitävistä huviveneistä tai maakunnan viranomaisten tietojenantovelvollisuudesta, se ei itsehallintolaissa säädetyn maakunnan ja valtakunnan välisen lainsäädäntövallan jaon näkökulmasta ole ongelmallinen. Sääntelyä ei myöskään voida katsoa ongelmalliseksi perustuslain 6 \$:n yhdenvertaisuusperiaatteen näkökulmasta, koska ilmoitusvelvollisuus on lähtökohtaisesti säädetty kaikille veneverovelvollisille. Sille, että Ahvenanmaalta kotoisin olevat veneverovelvolliset joutuisivat ilmoitusvelvollisuuden piiriin suuremmassa määrin kuin mannermaalla asuvat, on hyväksyttävä peruste. Verovelvollisten tasapuolinen kohtelu verotuksessa edellyttää, että veneverovelvollisia Ahvenanmaalla ei jätetä veneverotuksen ulkopuolelle siitä syystä, että maakunnalla on lainsäädäntövaltaa säätää veneliikenteeseen kuuluvista asioista.

Oikeusministeriö teki myös hyvin paljon lakiteknisiä ja muitakin korjausehdotuksia säännöksiin siltä osin kuin ne koskivat rangaistuksia, toimenpiteestä luopumista, todistustaakkaa, tietojen julkisuutta sekä säädösviittauksia. 


\subsection{Sisäministeriö, Poliisihallitus, Rajavartiolaitos ja Tulli}

Sisäministeriön poliisiosasto totesi, että esityksen mukaan vero koskisi myös niitä viranomaisten käytössä olevia vesikulkuneuvoja, jotka ovat rekisterissä - siis myös poliisiveneitä ja muita poliisin vesikulkuneuvoja. Poliisin vesikulkuneuvot tulisi vapauttaa veneverosta samoin perustein, joilla Poliisin ajoneuvot ovat verosta vapautettuja ajoneuvoverolaissa. Venevero lisäisi tarpeettomasti poliisitoimen kustannuksia ja hallinnollista taakkaa.

Veron piiriin tulisivat myös pelastustoimintaan rannikko- ja järvialueilla käytettävät vapaaehtoisen pelastustoiminnan pelastusveneet, joten vero lisäisi myös vapaaehtoisen pelastustoiminnan kustannuksia. Vapaaehtoinen pelastustoiminta suorittaa pelastustoimintaa vesialueilla ja siten tukee merkittävällä tavalla viranomaistoimintaa. Meri- ja järvialueiden vapaaehtoiseen pelastustoimintaan kohdistuvat lisäkustannukset heikentäisivät turvallisuutta vesialueilla. Suomen meripelastusseura ry:n vapaaehtoiseen pelastuspalveluun käytettäviä vesikulkuneuvoja ei tulisi verottaa. Poliisin toteuttamaa verovalvontaa pystyttäisiin tekemään lähinnä muun vesiliikennevalvonnan yhteydessä. On tärkeää, että verotukseen liittyvien tietojen luovuttaminen valvovilta viranomaisilta Trafille olisi riittävästi huomioitu säännöksissä.

Sisäministeriön pelastusosasto totesi, että veron piiriin tulisivat pelastustoimintaan meri- ja järvialueilla käytettävät pelastusveneet, joten vero lisäisi myös vapaaehtoisen pelastustoiminnan kustannuksia. Mainittuja veneitä on yhteensä yli 1000 . Pelastustoimintaan ja öljyntorjuntaan käytettävät pelastusveneet (pelastuslaitosten veneet, sopimuspalokuntien veneet ja muiden pelastustoimintaan osallistuvien yhteisöjen veneet) ja muut vesikulkuneuvot tulisi rajata verotuksen ulkopuolelle. Verotus kohdistuisi pääosin sellaisiin tahoihin, joilla ei ole omaa maksuvalmiutta vaan joille varat tulisi ohjata julkisista varoista. Sopimuspalokuntien ja muiden pelastustoimintaan osallistuvien yhteiskunnallisesti hyödyllisten yhteisöjen toimintaedellytyksiä ei tulisi rasittaa kaavaillun kaltaisella verotuksella. Myöskään kuntien rasitteita pelastustoimessa ei myöskään tulisi lisätä. Ehdotettu verotus saattaisi pahimmassa tapauksessa heikentää turvallisuutta. 
Poliisihallitus totesi, että veneveron suorittamista valvoisivat Tulli, poliisi ja Rajavartiolaitos vesiliikenteen valvonnan yhteydessä. Mikäli valvonnassa todetaan veronmaksuun liittyviä puutteita, niistä tulisi ilmoittaa Trafille. Tavoitteena tulisi olla, että tämä tiedon välittäminen tapahtuisi sähköisellä lomakkeella poliisin järjestelmästä suoraan Trafin järjestelmään. Poliisin käytössä on 62 sellaista venettä, joita uusi venevero tulisi koskemaan. Veron maksuun liittyvät prosessikulut ja menettelyyn kuluva työaika puoltavat sitä, että veneveron ei pitäisi koskea poliisiveneitä. Menettely olisi linjassa sen kanssa, että ajoneuvovero ei koske poliisiajoneuvoja.

Rajavartiolaitos totesi, että esityksessä kuvattua menettelyä voidaan pitää valvontaviranomaisen näkökulmasta riittävän toimivana käytännön toteuttamisen kannalta. Veroa kannettaisiin ja valvottaisiin myös Ahvenanmaan maakunnassa. Näyttäisi siltä, että Rajavartiolaitos voisi valvoa veneveron maksamista vesiliikenteen valvonnan yhteydessä myös Ahvenanmaan maakunnan vesialueella. Rajavartiolaitos piti kuitenkin välttämättömänä, että tästä asiasta pyydetään myös Ahvenanmaan asioista vastaavan oikeusministeriön sekä Ahvenanmaan maakunnan lausunto ja että asiasta kirjataan eduskunnalle menevään hallituksen esitykseen selkeä kanta. Veneveroa ei kannettaisi Rajavartiolaitoksen aluksista. Tätä on pidettävä tarkoituksenmukaisena, ja siinä otetaan asianmukaisesti huomioon hallitusohjelman norminpurkua ja hallinnollisen taakan vähentämistä koskevat tavoitteet. Veneverolaissa säädettäisiin venevero vapaaehtoisten meripelastusseurojen aluksille. Rajavartiolaitos piti tätä erittäin huonona asiana ja edellytti meripelastukseen käytettävien alusten vapauttamista veneveron maksuvelvollisuudesta.

Tulli totesi, että luonnoksen mukaan Tulli ja muut valvontaviranomaiset toteuttaisivat valvontaa lähinnä muiden valvontatoimenpiteiden yhteydessä. Tulli piti tällaista valvontatehtävän märittelyä sopivana, sillä nykyisin voimavaroin Tullilla ei ole mahdollisuuksia tätä kattavampaan veneveron valvontatehtävään ja ehdotuksessa ei esitetä Tullille valvontaresurssien lisäämistä. Tullilla ei ole tarkkaa käsitystä siitä, mitä seikkoja Tulli muiden valvontatehtäviensä yhteydessä veneveron osalta valvoisi. Manner-Suomessahan venevero kannettaisiin venerekisterin tietojen perustella. Tällöin Tullin valvonnassa ilmeisesti kiinnitettäisiin huomiota siihen, havaitaanko vesistössä 
olevan veneveron alainen vene, josta puuttuu rekisteritunnus, tai siihen, että tunnuksen oletetaan olevan väärä. Mahdollisesti myös veneen moottorin tehon poikkeamat rekisteritietoihin verrattuna voisivat olla valvonnan kohteina.

Tulli valvoisi todennäköisesti myös sitä, onko Suomessa vesistössä havaitun vesikulkuneuvon omistajan tai haltijan kotipaikka muualla kuin Suomessa. Tällaisista tilapäisesti Suomessa olevista vesikulkuneuvoista ei nimittäin ole rekisteröintivelvollisuutta, eikä niistä sen vuoksi myöskään kanneta veroa. Ahvenanmaalla Tulli valvoisi myös sitä, onko veneveron alaisissa veneissä verotunnus, jonka Trafi antaisi niille veneille, joita ei merkitä venerekisteriin. Henkilötietojen käsittelystä Tullissa annetun lain mukaan Tullilla on oikeus saada tietoja vesikulkuneuvorekisteristä muun muassa tulli- ja verovalvontaa varten. Säännös oikeuttaa Tullin saamaan tietoja vesikulkuneuvorekisteristä myös uuden veneveron valvontaa varten.

\subsection{Ahvenanmaa ja Paraisten kaupunki}

Ahvenanmaan maakuntahallitus vastusti veneveroa. Sen mukaan on epätarkoituksenmukaista luoda uusia veromuotoja, joissa byrokratia paisuu ja joissa kantokustannukset uhkaavat mitätöidä verotulot. Venevero kohdistuisi maassa epätasaisesti. Asukkaat maan rannikkoseuduilla mukaan lukien itsehallinnollinen Ahvenanmaa joutuisivat vastaamaan suuresta osasta veroa. Näillä alueilla vene on usein välttämätön kulkuneuvo, mikä merkitsee sitä, että veneen hankinnan syynä on tarve osallistua tuotantoelämään. Venevero voisi vaikuttaa kielteisesti veneturismiin, mistä taas on negatiivisia seurauksia Ahvenanmaalle. Ahvenanmaalla, kuten koko maassa, on meneillään kattava työ julkisen byrokratian vähentämiseksi. Veneveroehdotus ei sovellu tähän tavoitteeseen.

Statens ämbetsverk på Åland (SÄA) totesi, että Ahvenanmaalla on laaja saaristo, jossa veneet ovat suureksi osaksi välttämättömiä kulkuvälineitä. Venevero on siksi saanut Ahvenanmaalla laajaa kritiikkiä. Maakunnan uudessa vesikulkuneuvolaissa rekisteröintirajaa korote- 
taan niin, että sen piiriin kuuluvat vain suurimmat ja nopeimmat moottoriveneet. Koska rekisterimerkintää ei Ahvenanmaan osalta voida panna verotuksen perusteeksi, olisi veneet verotusta varten yksilöitävä Trafin antamilla veronumeroilla. SÄÅ on veronkantoviranomaisena valmis käsittelemään ehdotetut tehtävät edellyttäen, että se saa riittävästi varoja siihen. Avustavat tehtävät, joita ehdotetaan SÄÅ:lle, ovat asiakasneuvonta, ilmoitusten vastaanotto sekä rekisteröinnit. Toinen mahdollisuus olisi, että Verohallinto hoitaisi nämä tehtävät veroilmoitusmenettelyssä. SÄÅ:lle tulevat tehtävät vastaavat

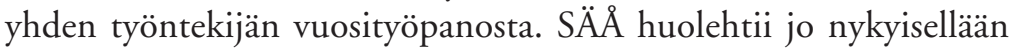
ajoneuvoverotuksesta Ahvenanmaalla.

Paraisten kaupunki totesi verolla olevan vakavia kielteisiä seurauksia. Hallituksen tavoitteena on vähentää byrokratiaa, mutta venevero merkitsisi byrokratian lisäämistä samalla kun veron tuotolla olisi marginaalinen merkitys. Vero kohdistuisi epäoikeudenmukaisesti tavallisiin palkansaajiin, yrittäjiin ja eläkeläisiin. Saaristossa vene on usein välttämätön kulkuväline. Erityisen ankarasti vero kohtelisi perheitä ja yrityksiä, joilla on useita veneitä. Veneily on hieno harrastus monille, jotka kokoavat koko perheen yhteisille veneretkille. Miksi pitää tervettä ja hauskaa vapaa-ajan toimintaa rangaista ja asettaa se huonompaan asemaan kuin muu vastaava toiminta? Venevero on kansainvälisesti hyvin epätavallinen veromuoto. Siellä, missä vero on otettu käyttöön, se on yleensä nopeasti kumottu kielteisten seuraamusten takia; vero on vähentänyt veneteollisuuden työpaikkoja ja polttoaineverotuloja, siirtänyt veneitä toisten maiden rekistereihin jne. Veneveron vuotuiseksi tuotoksi on esityksessä arvioitu 17 miljoonaa euroa. Luultavasti tulot jäisivät vielä pienemmiksi verosuunnittelumahdollisuuksien sekä veneilyharrastuksen vähenemisen takia. Vero myös uhkaa vähentää saaristoturismia. Vierassatamien liikevaihto pienenee ja ravintolat saavat vähemmän asiakkaita. Tulisi lisätä resursseja kehittää saaristoamme ja sen suuria mahdollisuuksia sen sijaan, että säädetään erilaisia maksuja ja veroja. 


\subsection{Veronmaksajain Keskusliitto ry}

Liitto vastusti esitetyn veneveron säätämistä, koska

- veneveron kaltainen, vain tiettyjä tavaroita koskeva pistevero ei ole hyvää verolainsäädäntöä,

- veneveroa ei voida pitää haittaverona, koska sen määrä ei ole riippuvainen veneen päästöistä tai muista haitoista,

- huviveneilyn vähentäminen ei ole hyväksyttävä peruste verolle,

- veron keräämisestä aiheutuvat menot ovat todennäköisesti huomattavasti esitettyä suuremmat, jolloin verotuskustannus suhteessa veron tuottoon nousee kohtuuttomaksi.

\subsection{Suomen Yrittäjät ry}

Suomen Yrittäjät suhtautui veneveroon kielteisesti. Vaikka veropolitiikassa hyväksyttävä suunta on ollut painopisteen siirtäminen työn verottamisesta välilliseen verotukseen, samaan aikaan on myös pyritty välttämään liian kapea-alaisia ja vanhakantaisia pisteveroja. Aiemmin näitä pyrittiin liittämään eri toimintoihin fiskaalisin tarkoituksin ilman muunlaista ohjaustarvetta (mm. televero).

Veneiden valmistuksessa, vuokrauksessa sekä tukku- ja vähittäiskaupassa toimii alle 800 yritystä ja työskentelee noin 3000 henkeä. Alan yhteenlaskettu liikevaihto on runsaat 600 miljoonaa euroa, ja tuotannosta $70 \%$ menee vientiin. Kyse on talouden kokonaisuutta ajatellen kapeasta ja erikoisosaamiseen keskittyneestä toimialasta, jonka toimintaan vero vaikuttaisi kielteisesti.

Venevero vaikuttaisi kotitalouksien vapaa-ajan kulutuskäyttäytymiseen. Veneisiin kohdistuva kuluttaminen vähenisi, mikä heikentäisi venealan myynti- ja valmistusnäkymiä ja siirtäisi painopistettä pienempiin veneisiin. Veneilyyn liittyvien matkailupalveluiden kysyntä on tuonut lisätuloja rannikko- ja sisävesien kunnille, ja tätä kysyntää esitys samalla heikentää.

Verotuksen oikeudenmukaisuuden näkökulmasta on ongelmallista, että venerekisterin tiedot ovat puutteellisia. Venerekisterissä on ainakin 10000 venettä, joita ei ole enää olemassa, ja rekisteristä 
puuttuu veron piiriin ehdotettuja veneitä. Veneistä maksetaan muita veroja, kuten polttoaineveroja ja ostohetkellä arvonlisäveroa.

Venevero on erityisen ongelmallinen pk-yrityksille. Kapeana tasasuuruisena erillisverona se kohdistuu voimakkaimmin pienimpiin yrityksiin. Jos yrityksellä on esimerkiksi 100000 euron liikevaihto ja 15 moottorivenettä ja 15 vesijettiä, joiden keskimääräinen vero on 150 euroa vuodessa, uusi vero on noin 4,5\% liikevaihdosta. Tämä on merkittävä veronkiristys, vaikka hallitusohjelmassa on päinvastoin pyritty estämään veroasteen nousu.

Ammattimaisessa käytössä olevien vesikulkuneuvojen vero merkitsisi veron piiriin kuuluville matkailuyrityksille merkittävää yksittäisen toimialan veronkiristystä, josta todennäköisesti kaikki pienyritykset eivät suoriutuisi. Ammattimainen veneiden tai vesikulkuneuvojen käyttö matkailu- ja ohjelmapalvelutoiminnassa tulisi joka tapauksessa rajata veron ulkopuolelle. Rajaus voitaisiin toteuttaa jättämällä arvonlisäverollinen käyttö kokonaan veron ulkopuolelle.

\subsection{Venealan Keskusliitto Finnboat ry}

\subsubsection{Venealan vastuu julkisesta taloudesta}

Yhdistys lausui, että veneala kantaa vastuunsa maamme saattamisessa jaloilleen. Siihen vaikutetaan muun muassa pitämällä huolta siitä, että kauppatase on oikean suuntainen. Veneteollisuutemme oman valmistuksen arvosta yli $70 \%$ menee vientiin. Veneala on tehnyt voitavansa, että työpaikat säilyisivät Suomessa. Maamme on kaukana markkinoista, ja halvemman työvoiman maista (kuten Puolasta) tuleva kilpailu asettaa teollisuutemme äärimmäisen kovaan kilpailuun.

Maassamme on veneily suuressa murrosvaiheessa. Kuluttajan vapaa-ajankäyttötavat ovat muuttumassa radikaalisti. Matka- ja retkiveneilyn osuus laskee seuraavan kymmenen vuoden aikana, koska vapaa-ajalta haetaan monipuolisuutta. Mökkeily, matkailu ja eri urheilulajit vievät osansa kuluttajien ajasta, ja sitä kautta halu investoida veneisiin (tai muihin pääomaa vaativiin harrastuksiin) vähenee. Lisäkustannukset, olivatpa ne luonteeltaan tai kooltaan mitä tahansa, vaikuttavat negatiivisesti veneilyn määrään Suomessa. 
Venevero vaikuttaisi erittäin negatiivisesti veneilyyn ja venealan mahdollisuuksiin kantaa vastuunsa julkisesta taloudesta erityisesti siksi, että se vähentäisi veneilyn tuottamia arvonlisä- ja polttoaineverotuottoja.

\subsubsection{Fiskaalinen vaikutus}

Jo esityksessä julki tuodut epäilyt veneveron pääasiallisen tavoitteen eli fiskaalisen tavoitteen täyttymisestä kyseenalaistavat veneveron perustan. Luonnoksessa on tyydytty arvioimaan välillisiä vaikutuksia numeerisesti vain siltä osin kuin venevero vähentäisi kotitalouksien käytettävissä olevia tuloja. Esityksessä on todettu, että veron käyttöönotto voisi johtaa venealan kannattavuuden ja yleisten toimintamahdollisuuksien lievään heikentymiseen ja jopa työpaikkojen menetykseen. Näiden vaikutusten lisäksi huomioon tulee kuitenkin ottaa ne verotuottojen menetykset, jotka aiheutuvat suoraan veneiden myynnin ja käytön vähenemisestä veneveron käyttöönoton seurauksena.

\subsubsection{Veneily ja veneet Suomessa}

Suomessa on noin 817000 vesikulkuneuvoa. Niistä noin 203000 on rekisteröintivelvoitteen alaisia, ja periaatteessa niiden pitäisi löytyä Trafin venerekisteristä. Venerekisteri on kuitenkin puutteellinen, ja vaatii melkoisesti työtä ennen kuin vuonna 2014 maistraateista siirretyn venerekisterin tiedot voisivat toimia verotuksen pohjana. Alla esitetyt luvut perustuvat kuitenkin tuohon rekisteriin. Venerekisterissä olevien veneiden määrä kokoluokittain jakautuu seuraavasti:

\begin{tabular}{lr} 
Perämoottoriveneet & 135000 \\
Sisämoottori-/sisäperämoottoriveneet & 49000 \\
Purjeveneet & 14000 \\
Muut (pääsääntöisesti vesijetit) & 4800 \\
\hline Yhteensä & 202800
\end{tabular}


Todelliset veneiden määrät ovat merkittävästi pienempiä kuin edellä mainitut. Rekisterissä on ainakin 20000 "haamuvenettä" eli käytöstä poistettua venettä.

Seuraavassa kuvataan konkreettisesti, millainen kunkin venetyypin keskimääräinen vene on ja mihin sitä käytetään.

1) Perämoottorivene (135000 kpl): Terhi 445 edustaa hyvin keskimääräistä mökki-, kalastus-, perhe- ja muussa sellaisessa käytössä olevaa rekisteröityä perämoottorivenettä. Hintaluokka on keskimäärin 12 000-15 000 euroa. Näitä venetyyppejä on rekisterissä eniten.

2) Sisämoottori-/sisäperämoottorivene (49 $000 \mathrm{kpl}$ ): Tässä luokassa vaihteluvälit ovat selkeästi suuremmat, mutta rekisterissä olevista tämän tyypin veneistä valtaosa on keskimäärin 6-7 metrin kokoluokassa olevia retki- ja yhteysveneitä. Hinta vaihtelee 50 000-130 000 euron välillä. Todettakoon, että yli 10 metrin moottoriveneitä on viime vuosina toimitettu vain 10-20 kappaletta per vuosi.

3) Purjeveneet (14 $000 \mathrm{kpl})$ : Purjeveneiden kauppa on käytännössä pudonnut $90 \%$ vuodesta 2008 . Vuosittain myydään alle 20 uutta purjevenettä. Rekisterissä olevat purjeveneet ovat jo melko iäkkäitä, kuten omistajansakin. Yleisin malli on suuruusluokassa 30 jalkaa, ja muutaman vuoden ikäisenä sellaisen veneen hinta on alle 100000 euroa.

4) Muut rekisterissä olevat vesikulkuneuvot (4 $800 \mathrm{kpl}$ ): Nämä ovat pääasiassa niin sanottuja vesijettejä. Ne ovat vesivetolaitteen avulla kulkevia kahden tai useamman istuttavia nopeakulkuisia laitteita, joiden hintaluokat uusina ovat noin 7 000-30 000 euroa.

\subsubsection{Verokertymä veneilystä}

Venettä harva välttämättä tarvitsee. Kyse ei ole samankaltaisesta välttämättömyyshyödykkeestä kuin esimerkiksi auto on monille. Tällä on vaikutusta muun muassa veneen hankintaan tai siitä luopumiseen sekä veneilyyn käytettyyn aikaan. Usein veneilyn kannalta keskeistä 
on käytettävissä oleva aika ja kustannukset. Keskimääräisen veneilijän kulut (euroa/veneilykausi) vuodessa ovat seuraavat:

\begin{tabular}{ll} 
- käyttökustannukset (polttoaine yms.) & 735 \\
- huoltopalvelut ja korjaus & 327 \\
- laituripaikka & 220 \\
- talvisäilytys & 281 \\
- varusteiden uusiminen & 357 \\
- vakuutukset & 325 \\
- muut kulut & 267 \\
\hline yhteensä & 2512 euroa/veneilykausi
\end{tabular}

Esimerkissä on kyse keskivertoveneestä, jonka käyttötunnit ovat noin 30 tuntia vuodessa. Venettä käytetään siis keskimär̈in kolmen kuukauden veneilykauden aikana 10 tuntia kuukaudessa.

Valtion verotuloja veneilystä kokonaisuutena on haastavaa koota yhteen. Jos arvioinnin perustana käytetään yllä olevaa keskimääräistä kulurakennetta, niin valtion osuus saatavina veroina on noin 976 euroa /vene. Jos kaikki venerekisterissä olevat veneet soveltavat samaa kulurakennetta (mikä ei ole mahdotonta), veneily tuottaa valtiolle verotuloina noin 199 miljoonaa euroa vuodessa. Jos uusia veneitä, moottoreita, varusteita sekä veneilyyn liittyviä palveluja lisäksi myydään vuodessa 254 miljoonalla eurolla, valtion osuus saatavina arvonlisäverotuloina olisi arviolta 61 miljoonaa euroa vuodessa. Lisäksi veneala työllistää noin 3500 henkilöä (Finnboat ry:n jäsenistö), joiden toiminnan tuottamaa tuloverokertymää ei voi jättää huomiotta. Valtion investoinnit muun muassa pienveneväyläverkoston ylläpitoon eivät ole kovin suuria. Yhteenvetona voidaan todeta, että veneily tuottaa valtiolle verotuloina vuodessa seuraavasti:

\begin{tabular}{|l|r|}
\hline käyttöön liittyvät verot & 199000000 euroa \\
\hline arvonlisävero uusista tuotteista & 61000000 euroa \\
\hline muut verotuotot veneilystä & 260000000 euroa \\
\hline
\end{tabular}




\subsubsection{Veneilyn kehittyminen lähivuosina}

Pääosa veneistämme on pieniä "mökkiveneitä", ja venerekisterissäkin olevista valtaosa on pieniä avoveneitä, joita käytetään vapaa-ajan harrastuksiin. Veneily tulee suurten ikäluokkien ikääntymisen myötä merkittävästi vähenemään. Taloudellinen epävarmuus on viimeisen kahdeksan vuoden aikana pudottanut venekauppaa 35-40 \%. Lisäksi kuluttajien vapaa-ajan käyttö on muuttunut ja edelleen muuttuu radikaalisti. Nämä tekijät tulevat edelleen vähentämään venekaupan ja myös veneilyn määrää useita prosenttiyksiköitä vuodessa. Veneverolla on sen taloudellista merkitystä suurempi veneilyä vähentävä signaalinen merkitys. Toki myös veneveron kustannuksella on merkitystä, erityisesti kun veneen käyttö on Suomessa olosuhteista johtuen kausiluonteista ja rajoittuu noin 34 kuukauteen vuodessa.

\subsubsection{Veneveron negatiiviset vaikutukset valtion kokonaisverotuloihin}

Arvion mukaan veropäätös aiheuttaa kahtena ensimmäisenä vuotena noin $10 \%$ :n suuruisen myynti- ja käyttövolyymin laskun. Seuraavina vuosina lasku saattaa olla maltillisempaa mutta kuitenkin selvästi suurempaa kuin veroehdotuksessa on esitetty. Vaikka volyymin lasku olisi pienempääkin, veron negatiiviset signaalivaikutukset aiheuttavat veneilystä kertyviin välillisiin verotuottoihin selvästi suuremman pudotuksen kuin veron tuotto valtiolle olisi. Laskelmissa ei ole huomioitu vähenevän veneilyn kerrannaisvaikutuksia, muun muassa saariston kauppojen, vierasvenesatamien ja muiden veneilypalvelujen kysynnän laskua. Myös saaristoelinkeinon vaatimukset saada valtion tukea tulevat kasvamaan merkittävästi.

Suoranainen verotuottojen pudotus neljän vuoden jaksolla lähtöarvoon (v. 2016) verrattuna olisi Finnboatin jäsenkunnan arvion mukaan 223 miljoonaa euroa.

Tilanteessa, jossa kuluttajat ovat hajauttamassa vapaa-aikaansa ja veneilyn määrä sitä kautta maassamme joka tapauksessa vähenee, vero tulee merkittävästi kiihdyttämään tätä kehitystä. Veneilyn vähentymisen seurauksena verotulojen lisäys ei veneveron käyttöönoton myötä 
toteutuisi vaan päinvastoin kokonaisuutena pienentyisi. Kärsijöiden joukossa olisivat myös herkästi haavoittuva saaristoelinkeino ja rannikkojen pienet kaupungit.

Teollisuuden ja kaupan kohdalla tulee venealalta ja siitä riippuvaisilta sektoreilta häviämään satoja työpaikkoja, jos venevero toteutetaan. Vaikutus voisi olla teollisuuden puolella merkittävästi suurempikin, kun laskevan kysynnän vuoksi kotimaisten toimijoiden tuotantomäärät pienenevät, mikä entisestään lisäisi halpatuotantomaista tulevaa kilpailua. Venevero ei siis olisi viisasta elinkeinopolitiikkaa. Mutta jos valtio uuden veron säätämisen sijasta investoisi veneilijöiden palvelujen kehittämiseen ja alan teollisuuden kansainvälistymiseen, suunnitellun veron tuottoa vastaava summa tulisi moninkertaisena takaisin jo muutamassa vuodessa.

\subsubsection{Verotuottovakaus ja fiskaalinen joustavuus}

Verot voidaan jakaa fiskaalisiin ja ohjaaviin veroihin. Veneveron tavoite on yksiselitteisesti fiskaalinen eli valtion verotulojen lisääminen, ja tämän tavoitteen täyttyminen on jo itsessään erittäin epätodennäköistä. Lisäksi veneveroon liittyy useita muita heikkouksia, jotka kyseenalaistavat sen tarkoituksenmukaisuuden fiskaalisena verona. Hyvältä fiskaaliselta verolta voidaan edellyttää verotuottovakautta. Verotuottovakauden kannalta yksi keskeinen tekijä on se, miten helposti verovelvolliset voivat välttää veron. Veron välttämisessä keskeisessä asemassa ovat yhtäl̈ltä kysynnän hintajouston käsite eli se, miten helposti kysyntä reagoi kyseessä olevan hyödykkeen hintamuutoksiin, ja toisaalta se, kuinka hyvin verot suoritetaan, eli toteutuvan verokertymän suuruus.

Ajoneuvoveroa on yleensä pidetty verotuottovakauden näkökulmasta ihanteellisena verona.

Ajoneuvo on tyypillisesti välttämättömyyshyödyke, jota ilman ainakin työssäkäyvän, haja-asutusalueella asuvan tai perheellisen ihmisen on vaikea toimeen. Sen korvaaminen täysin jollakin vaihtoehtoisella ei-verotetulla hyödykkeellä on käytännössä vaikeaa. Veneveron kohteena ovat pääsääntöisesti harrastuskäytössä olevat veneet. Veneveron vaikutukset veneilyyn ovat merkittävästi suuremmat kuin 
ajoneuvoveron vaikutukset autoiluun. Ääritapauksessa veneilystä voidaan luopua ja se voidaan korvata se jollakin vaihtoehtoisella vapaaajan harrastusmuodolla. Verotuottovakauden näkökulmasta venevero on huono fiskaalinen vero.

Myös verokertymän näkökulmasta ajoneuvoveroa voidaan pitää ihanteellisena verona.

Ajoneuvoveron suorittamatta jättämisestä seuraa ajoneuvon käytön estymine ja se, ettei ajoneuvoa voi katsastaa. Venevero on tästäkin näkökulmasta huono fiskaalinen vero. Esityksessä on tämä todettukin: veneille ei ole pakollista katsastusvelvollisuutta, ja vesiliikenteessä valvontamahdollisuudet ovat tieliikenteen valvontamahdollisuuksia vähäisempiä etenkin sisävesillä, mikä heikentää myös verovalvonnan mahdollisuuksia.

Hyvältä fiskaaliselta verolta edellytetään myös fiskaalista joustavuutta, jolla tarkoitetaan sitä, miten hyvät edellytykset vero tarjoaa lisäverotuottojen lähteeksi. Tästäkin näkökulmasta venevero on huono. Se on kapeapohjainen vero, jonka verotuottopotentiaali on huono. Vaikka venemäärä sinällään on suuri, veron kohteeksi mahdollisten veneiden määrä on huomattavasti pienempi. Venerekisteröintivelvollisuus koskee vain pientä osaa venekannasta. Vuonna 2004 käytössä oli yli 737000 venettä ja muuta vesikulkuneuvoa, joista yli 420 000:ssa käytettiin ainakin toisinaan moottoria. Nykyisin vesikulkuneuvoja arvioidaan olevan yli 800 000, ja niistä rekisteröintivelvollisuus koskee noin neljäsosaa eli reilua 200 000:ta. Jo ehdotetuilla veroperusteilla vero nousee useissa tapauksissa varsin korkeaksi, kun se suhteutetaan veneen käyttöpäiviin, muihin veneen käytöstä aiheutuviin kustannuksiin tai veneen arvoon. Näin ollen verotuottopotentiaalin merkittävä lisääminen veroperusteita kiristämällä ei olisi mahdollista.

Jos kyseessä on selkeästi ohjaava vero, jonka perusteena on esimerkiksi haitallisten ympäristövaikutusten estäminen, verotuottovakaus ja fiskaalinen joustavuus voivat olla merkitykseltään toissijaisia suhteessa ohjaustavoitteeseen. Veneveron tavoite on puhtaasti fiskaalinen, jolloin verotuottovakaudelle ja fiskaaliselle joustavuudelle tulisi antaa keskeinen merkitys veron tarkoituksenmukaisuutta arvioitaessa. Tästäkin näkökulmasta veneverosta tulisi luopua, koska venevero ei täytä hyvän fiskaalisen veron ominaisuuksia. 


\subsubsection{Veneveron epäneutraalisuus ja haitalliset ohjausvaikutukset}

Kapeapohjaisten verojen keskeisiä ongelmia ovat niiden aiheuttamat epäneutraalisuudet ja haitalliset ohjausvaikutukset. Veneveron kohteena olisivat pääosin harrastuskäytössä olevat veneet. Siinä on kyse yhden harrastusmuodon "pisteverotuksesta", joka voi johtaa epäneutraalisuuteen suhteessa muihin ei-pisteverotettuihin harrastusmuotoihin.

Veneveron toteuttamisella olisi useita epäneutraalisuuksia ja haitallisia ohjausvaikutuksia. Vero rajattaisiin vesikulkuneuvoihin, joiden moottoriteho on vähintään 38 kilowattia $(=\mathrm{n} .52 \mathrm{hv})$. Esityksessä todetaan, että vero koskisi näin vain melko isotehoisella moottorilla varustettuja veneitä ja sen ulkopuolelle jäisi siten suuri osa käytössä olevista perämoottorilla varustetuista veneistä. Ehdotetun moottoritehon alarajan perusteella esityksessä on useissa kohdin todettu, että moottoritehoon perustuvan veron alaraja on 100 euroa. Käytännössä nimittäin moottoritehoon perustuvan veron alaraja on korkeampi kuin esitetty 100 euroa. Käytännössä moottorikokoon perustuva vero koskee 60 hevosvoiman eli noin 44,1 kilowatin moottoriteholla varustettuja veneitä, jolloin vuotuisen veron määrä olisi 112 euroa. Moottorin tehoon perustuvan veron alaraja on siis käytännössä $12 \%$ korkeampi kuin esitetty, joitakin harvoja poikkeuksia lukuun ottamatta.

Ainakin pidemmällä aikavälillä veneverolla voisi olla vaikutusta veneen moottoritehoa koskeviin valintoihin sekä käyttäjien että valmistajien taholla. Merkittävin vaikutus voisi olla veron alarajalla, joka on omiaan ohjaamaan valintoja kohti pienempiä moottoritehoja. Veneverolla ei kuitenkaan ole ympäristövaikutustavoitteita, eli kyseessä ei ole luonteeltaan ohjaava vero. Kuluttajien valintojen ohjautuminen kohti pienempitehoisia moottoreita voi merkitä haitallista ohjausvaikutusta. Esimerkiksi avomerikäytössä moottoriteholla on merkitystä meriturvallisuuden kannalta.

Veneverolla voi olla haitallisia ohjausvaikutuksia veneiden kauppaan. Veron käyttöönottovaiheessa venekauppiaiden varastossa olevista veneistä myös voi koitua ylimääräinen kustannus venekauppiaille, joilla voi olla merkittävä määrä vaihtoveneitä. Suomessa myydään 
arviolta 15 000-20 000 vaihtovenettä vuosittain, joten kauppiaiden varastoissa niitä on veneilykauden ulkopuolella varastossa tuhansia. Veneveron kohdistumista kauppiaan varastossa oleviin veneisiin ei ole esityksessä huomioitu. Tämä voi johtaa siihen, että veneitä joudutaan poistamaan venerekisteristä ja uudelleenrekisteröimään epätarkoituksenmukaisen veneverovelvollisuuden välttämiseksi. Liukuvalla verokaudella voi muutoinkin olla haitallisia vaikutuksia venekaupan ajoittumiseen, jos veneiden ostajat pyrkivät "optimoimaan" verokauden ja veneilykauden alkamis- ja päättymisajankohdat verovelvollisuuden minimoimiseksi.

\subsubsection{Oikeudenmukaisuusnäkökohtia}

Sana "oikeudenmukaisuus" esiintyy ehdotuksessa kolme kertaa. Oikeudenmukaisuutta on tarkasteltu erityisesti veron kohteen ja veroperusteiden määrittämisen näkökulmasta. Esityksessä katsotaan, että kaikkiin veneisiin sovellettava tasasuuruinen vero olisi oikeudenmukaisuuden näkökulmasta ongelmallinen. Todetaan myös, että käytännön syistä veneveron veroperusteen tulisi liittyä johonkin venerekisterin tiedoista kaikista veneistä saatavaan tekniseen ominaisuuteen tai niiden yhdistelmään. Tällöin kysymykseen tulisivat lähinnä moottorin teho ja rungon pituus. Kuten esityksessä on todettu, veroa ei voida toteuttaa arvoperusteisesti, koska venerekisteri ei sisällä tietoa veneen arvosta.

Mainituista syistä veron perusteeksi otettaisiin vähintään 38 kilowatin eli noin 52 hevosvoiman moottoriteho tai vähintään 9 metrin runkopituus. Perusteluista ilmenee tarkoituksena olevan, että vero koskisi vain "melko isotehoisella" moottorilla varustettuja veneitä. Koska moottoritehoon perustuva vero jättäisi ulkopuolelle kuitenkin "varsin kookkaatkin purjeveneet", on oikeudenmukaisuussyistä katsottu, että toissijaiseksi veron perusteeksi tulisi säätää veneen rungon pituus.

Veneveron toteuttaminen nykyolosuhteissa ei ole mahdollista tavalla, joka täyttäisi verotuksen oikeudenmukaisuuden tavoitteen. Kuten seuraavat esimerkit osoittavat, veneveron kohdistuminen on täysin mielivaltaista erityisesti suhteessa veneen arvoon: 
- Uusi hollantilainen teräsvene, jossa moottori $50 \mathrm{hv}$, veneen pituus 8,5 metriä, hinta 175000 euroa: ei veroa.

- 50 hv:n perämoottorilla varustettu avovene, veneen pituus 5 metriä, hinta 35000 euroa: ei veroa.

- 50 vuotta vanha mäntyrunkoinen kalastajamallinen vene, 70 hv:n dieselmoottorilla, veneen arvo 5000 euroa: vero 122 euroa.

- Hai-purjevene vuodelta 1972, veneen pituus 9,80 metriä, veneen arvo 3000 euroa: vero 100 euroa.

Esityksen mukaan käytettävissä olevista teknisistä tiedoista moottoritehon voidaan katsoa jonkin verran kuvastavan veneen arvoa yleisellä tasolla. Tämän vuoksi moottoritehoon perustuva vero on ehdotettu porrastettavaksi siten, että vähintään 38 kilowatin tehoisella moottorilla varustetun veneen vero on 100 euroa ja 38 kilowatin ylittävältä osalta vero kasvaisi kahdella eurolla kultakin täydeltä kilowatilta. Tällä pyritään "lisäämään hieman veron oikeudenmukaisuutta tasaveroon verrattuna". Veron enimmäismääräksi ehdotetaan 300 euroa, joka vastaisi 138 kilowatin eli noin 188 hevosvoiman moottoritehoa. Ylärajalla pyritään välttämään veron nouseminen suhteettoman suureksi erityisesti niissä yksittäisissä tilanteissa, joissa moottoriteho ei välttämättä kuvasta suoraan veneen arvoa. Rungon pituuteen perustuvan veneveron osalta on kuitenkin päädytty hallinnollisen yksinkertaisuuden perusteella toisenlaiseen ratkaisuun eli siihen, että vero on kaikissa tapauksissa 100 euroa.

Ehdotettu tapa parantaa veneveron oikeudenmukaisuutta on sinällään oikeansuuntainen. Se ei kuitenkaan riitä poistamaan koko veneveron epäoikeudenmukaisuutta sekä suhteessa muihin harrastusmuotoihin että siihen, miten veron kohteet on määritelty. Veneveron säätäminen riittävän oikeudenmukaiselle tavalla ei ole mahdollista venerekisterin tuomien käytännön rajoitusten vuoksi, ja siksi veron toteuttamisesta tulisi luopua.

Veneily on kausiluonteista. Sitä harrastetaan keskimäärin 6-15 päivää vuodessa, jolloin veneveron suuruus olisi 7-50 euroa käyttöpäivältä. Myös esityksessä on kiinnitetty huomiota tähän ja mainittu vertailukohtana ajoneuvovero, joka on keskimäärin 0,67 euroa 
päivää kohden. Venevero voisi siis käyttöpäiviin suhteutettuna olla jopa monikymmenkertainen ajoneuvoveroon verrattuna. Toisin kuin ajoneuvoverossa, verokauden keskeyttäminen ei tässä olisi mahdollista verokohteen liikennekäytöstä poistamisella. Verolta voisi välttyä vain, jos vene olisi poistettuna venerekisteristä verokauden alkaessa. Tämä voi johtaa epätarkoituksenmukaisiin tilanteisiin, joissa vene kannattaa veron välttämiseksi poistaa venerekisteristä käyttökauden päätteeksi ja rekisteröidä uudelleen seuraavan käyttökauden alkaessa. Veneilykauden lyhyys yhdistettynä verokauden alkamisajankohtaan ja sen mahdolliseen muuttamiseen voi siis johtaa tapauskohtaisesti tilanteisiin, joissa osalla veneistä yksi verokausi kattaa kaksi veneilykautta, kun taas osalla veneistä yhtä verokautta vastaa yksi veneilykausi.

Esityksen mukaan venevero koskisi myös viranomaisten ja vapaaehtoisten harjoittamaan pelastustoimintaan käytettäviä pelastusveneitä. Tältäkin osin vertailu voidaan tehdä ajoneuvoveroon: ajoneuvoverosta vapautettuja ovat palo- tai pelastusauto, kun sillä osallistutaan kunnalliseen palo- tai pelastustoimintaan, ja sairasauto, kun sen omistajalla tai haltijalla on sairaankuljetuslupa. Perustelujen mukaan venevero koskee myös pelastusveneitä, koska ne ovat venerekisterissä. Tämäkin veneveroon liittyvä yksityiskohta osoittaa, ettei veneveron kohteiden rajauksia ole riittävästi mietitty oikeudenmukaisuus- tai muistakaan tarpeellisista näkökulmista.

Esityksessä on käsitelty ehdotetun veneveron tulonjakovaikutuksia. Perustelujen mukaan veneiden omistus on selvästi yleisempää ylemmissä tuloluokissa. Veneveron tulonjakovaikutusten osalta todetaan, että vaikutus olisi mittaluokaltaan pieni mutta kuitenkin progressiivinen eli suurituloisiin kotitalouksiin voimakkaammin kohdentuva.

Suomen verojärjestelmässä veronmaksukyvyn huomioon ottaminen eli niin sanottu vertikaalinen oikeudenmukaisuus toteutuu erityisesti progressiivisen ansiotuloverotuksen sekä perintö- ja lahjaverotuksen kautta. Kulutuksen verotus toteutetaan arvonlisäverotuksen kautta, ja lisäksi käyttöön kohdistuu muun muassa polttoaineverotus. Kaikki mainitut verot kohdistuvat jo nykyisellään koko veneilyn elinkaareen veneen hankinnasta veneen käyttöön asti. Yhteen harrastusmuotoon kohdistuva pistemäinen ylellisyysvero olisi nykyisen verojärjestelmämme näkökulmasta epäjohdonmukaista veropolitiikkaa ja merkitsisi paluuta menneisyyden ylellisyysveroajatteluun. 


\subsubsection{Venerekisterin puutteellisuudet ja epäluotettavuus}

Sipilän hallitusohjelman mukaan yksi verotuksen kärkitavoitteista on tämä: "Verotusmenettelyt ovat asiakaslähtöisiä ottaen huomioon verotuksen johdonmukaisuuden, ennakoitavuuden ja oikeusvarmuuden sekä tietojen saannin.” Venevero on jyrkässä ristiriidassa tämän tavoitteen kanssa. Kuten esityksessäkin on nimenomaisesti todettu, veneveron toteuttamisen ongelmana on pidetty Trafin ylläpitämän venerekisterin tietojen puutteellisuuksia ja veneveron valvontamahdollisuuksien vähäisyyttä, jotka osittain liittyvät juuri venerekisterin puutteisiin. Venerekisteriä ei ole suunniteltu käytettäväksi verotustarkoituksiin. Venerekisterin keskeinen käyttötarkoitus liittyy vesiliikenteen turvallisuuteen. Esityksessä on myös tuotu esiin aiheellinen huoli siitä, että rekisterin tietosisällön luotettavuus sen varsinaisen tarkoituksen suhteen voi kärsiä, jos rekisteristä aletaan poistaa veneitä veron välttämistarkoituksessa.

Veneveroa ei voida perustaa venerekisteriin, koska tämän tiedot eivät ole tarpeeksi kattavia ja luotettavia oikeudenmukaisen veron toteuttamiseksi ja ylläpitämiseksi. Esityksessä on todettu, että veneveron käyttöönoton ja venerekisterilain muutosten arvioitaisiin ajan myötä johtavan venerekisterin tietojen nykyistä tehokkaampaan päivittymiseen. Tämä lähestymistapa on täysin mahdoton hallinnollisen tehokkuuden ja verovelvollisten oikeusturvan kannalta. Se merkitsisi ensi vaiheessa sitä, että Trafi lähettäisi tuhansia, mahdollisesti kymmeniätuhansia, verolippuja väärille verovelvollisille venerekisterin virheellisten tai puutteellisten tietojen perusteella. Sen lisäksi, että venerekisterissä yhä on jo käytöstä poistettuja veneitä eli niin sanottuja haamuveneitä, veneiden omistajatiedoissa on merkittäviä puutteita. Esimerkkinä voidaan mainita osamaksulla ostetut veneet, joiden omistajina olleet rahoitusyhtiöt saattavat edelleen näkyä veneiden omistajina, sekä muut veneiden omistajanvaihdostilanteet, kuten myynnit ja perintötilanteet, joita ei ole asianmukaisesti rekisteriin merkitty. Lisäksi venerekisterin tietojen virheellisyydet voivat johtaa veron määräämiseen väärin perustein. Esimerkkinä voidaan mainita tilanne, jossa veneeseen on vaihdettu teholtaan aiempaa suurempi tai pienempi moottori mutta muutosta ei ole merkitty venerekisteriin. 


\subsubsection{Verovelvollisen ilmoittamisvelvollisuus}

Veroilmoitusta ei tarvitsisi tehdä niistä veneistä, jotka on rekisteröity venerekisteriin siitä annetun lain mukaisesti. Tällä perusteella suurimman osan veronalaisten veneiden omistajista tulisi vapautua erillisestä veroilmoitusvelvollisuudesta. Käytännössä venerekisterin nykyisistä virheellisyyksistä ja puutteellisuuksista johtuen veneveron käyttöönottovaiheessa erillinen ilmoittamisvelvollisuus koskisi kuitenkin tuhansia tai jopa kymmeniätuhansia veneiden omistajia. Esityksessä todetaankin, että veneveron yhteydessä venerekisterilakiin ehdotettujen muutosten olisi tarpeen tulla voimaan jo ennen veneverolain ehdotettua voimaantuloa, jotta verovelvollisilla olisi mahdollisuus tehdä tarvittavia rekisteri-ilmoituksia ennen kuin vero otetaan käyttöön. Esitetty lähestymistapa on aikataulullisesti täysin mahdoton ja verovelvollisten oikeusturvan vastainen. Venerekisterin ajantasaistamiseen tulee varata vähimmilläänkin yhdestä kahteen vuotta - vasta silloin ehdotettu vero voitaisiin toteuttaa verovelvollisten oikeusturvan kannalta kestävällä tavalla. Veneenomistajien ilmoittamisvelvollisuudella ei voida korjata venerekisterin puutteellisuuksia.

\subsubsection{Hallinnointikustannukset}

Hyvän verojärjestelmän keskeinen piirre on yksinkertaisuus: verotuksen hallinnointikustannusten ja verolain noudattamiskustannusten olisi oltava niin alhaiset kuin suinkin. Ehdotetun veneveron osalta nämä edellytykset eivät täyty. Veneveron toteuttamisen perustana ovat venerekisterin tiedot ja käytännössä toissijaisesti veneen omistajan veneveroilmoituksessa antamat tiedot. Lähtökohta on hallinnollisen tehokkuuden näkökulmasta oikea, mutta venerekisterin tiedoissa on merkittäviä virheitä ja puutteellisuuksia, koska rekisteriä ei ole tarkoitettu käytettäväksi verotuksessa. Siksi verotusta suuressa osassa tapauksia ei tosiasiassa voida perustaa venerekisterin nykyisiin tietoihin, vaan rekisterin tiedot on saatettava ajantasaisiksi sekä viranomaisettä verovelvollistoimin ennen kuin verotus voidaan toteuttaa oikealla tavalla. Mitä vähemmän veneveron toimittamisessa voidaan suoraan hyödyntää viranomaisrekistereitä, sitä työläämmäksi hallinnollisesti ja kalliimmaksi verotus muodostuu. 
Veneveron käyttöönotto edellyttäisi Trafin tietojärjestelmiin kertaluonteisia muutoksia, joista aiheutuu kustannuksia. Kertaluonteista lisätyötä aiheutuu myös asiakkaiden opastamisesta, ohjeistuksesta, lomakkeista ynnä muista vastaavista toimenpiteistä. Viranomaiskustannusten lisäksi verotuksen hallinnollista tehokkuutta ja kustannuksia tulee arvioida verovelvollisten näkökulmasta. Venerekisterin puutteellisuudet ja virheellisyydet tulevat aiheuttamaan merkittävää hallinnollista työtä myös verovelvollisille. Esimerkkinä voidaan mainita tilanne, jossa verolippu lähetetään venerekisterin virheellisten tietojen perusteella väärälle verovelvolliselle, jonka silloin tulee hakea oikaisua verotuspäätökseen.

Verovelvollisten verolain noudattamiskustannuksissa tulee lisäksi huomioida se, mitä toimenpiteitä veronvalvontatilanteessa verovelvolliselta edellytetään. Ehdotuksen mukaan Trafin lisäksi Tulli, Poliisi ja Rajavartiolaitos valvoisivat veron suorittamista ja oikeellisuutta. Käytännössä valvontatilanteessa niillä ei kuitenkaan aina ole yhteyttä Trafin ylläpitämään verorekisteriin, josta veron suorittamisvelvollisuuden täyttäminen voitaisiin todentaa. Siksi ehdotetussa veneverolaissa säädettäisiin verovelvolliselle tai muulle veneen käyttäjälle velvollisuus esittää valvontatilanteessa näyttö siitä, että vene on asianmukaisesti merkitty verorekisteriin. Perustelujen mukaan tämä käytännössä tarkoittaa, että viranomaiselle esitetään rekisteriote tai esimerkiksi kyseisen verokauden verolippu. Tästä vaatimuksesta tulisi aiheutumaan paljon käytännön ongelmatilanteita. Valvontaviranomaisten pääsy sekä venerekisteriin että Trafin veneveroa varten perustettavaan verorekisteriin tulisi varmistaa ennen ehdotetun veron toteuttamista. Vain näin verovelvollisten verolain noudattamiskustannukset ja veneveron asianmukainen verovalvonta saataisiin hyväksyttävälle tasolle.

\subsubsection{Verovelvollisten yhdenvertaisuus}

Perustuslain 81.1 \$:n mukaan valtion verosta säädetään lailla, joka sisältää säännökset verovelvollisuuden ja veron suuruuden perusteista sekä verovelvollisen oikeusturvasta.

Perustuslain 6.1 \$:n mukaan ihmiset ovat yhdenvertaisia lain edessä. Säännös ilmaisee paitsi vaatimuksen oikeudellisesta yhden- 
vertaisuudesta myös ajatuksen tosiasiallisesta tasa-arvosta. Yhdenvertaisuussäännös kohdistuu myös lainsäätäjään; lailla ei voida mielivaltaisesti asettaa kansalaisia tai kansalaisryhmiä toisia edullisempaan tai epäedullisempaan asemaan. Yhdenvertaisuussäännös ei kuitenkaan edellytä kaikkien samanlaista kohtelua, elleivät asiaan vaikuttavat olosuhteet ole samanlaisia.

Verovelvollisten yhdenvertaisuuteen on esityksessä viitattu siltä osin kuin kyse on venerekisterin tietojen käyttämisestä verotuksen perusteena. Esityksessä on todettu, että veneveron tulisi koskea yhdenmukaisin perustein sekä Manner-Suomessa että Ahvenanmaalla käytössä olevia veneitä. Ongelmallisen tilanteesta tekee se, että Ahvenanmaalla käytössä oleva venerekisteri soveltuu veneverotuksen tarpeisiin vielä huonommin kuin Trafin ylläpitämä venerekisteri, ja venerekisteriä koskeva lainsäädäntövalta on Ahvenanmaan itsehallintolain nojalla maakunnalla. Näin Ahvenanmaan venerekisterin puutteita ei voida edes yrittää korjata ehdotetun veneveron yhteydessä toteutettavin lainsäädäntötoimin, jota menettelyä Trafin ylläpitämän venerekisterin osalta on ehdotettu. Esityksessä on suoraan todettu, että Ahvenanmaan venerekisteri ei ole sellaisenaan käyttökelpoinen veneveron toteuttamisessa. Esimerkkeinä ongelmista on mainittu muun muassa, että purjeveneitä ei rekisteröidä ja rekisteristä ei voida poistaa käytöstä poistuneita veneitä. Lisäksi on todettu, että Ahvenanmaa voisi itsehallintonsa puitteissa muuttaa rekisteröinnin perusteita tai jopa luopua huviveneiden rekisteröintivelvollisuudesta.

Venerekisterien eroista aiheutuvia ongelmia on pyritty ratkaisemaan verovelvollisen eli veneen omistajan ilmoittamisvelvollisuudella. Kuten esityksessä on todettu, tämä johtaa käytännössä osin erilaiseen verotusmenettelyyn Manner-Suomessa ja Ahvenanmaalla.

Tulisi arvioida perustuslain 81.1 \$:n asettaman oikeusturvaedellytyksen ja 6.1 \$:n yhdenvertaisuusedellytyksen valossa tarkemmin sitä, voidaanko veneveron toimittaminen kytkeä ehdotetulla tavalla venerekisterin tietoihin tilanteessa, jossa Ahvenanmaan venerekisteriä ei voida valtakunnallisin lainsäädäntötoimin saattaa yhdenmukaiseksi Trafin venerekisterin kanssa ja ottaen huomioon vielä molempien rekisterien tietojen kattavuus- ja luotettavuusongelmat. Vastaava arviointi tulisi tehdä veneveron valvonnan osalta; valvonta voi asettaa verovelvolliset eriarvoiseen asemaan, jos siinä on merkittäviä eroja 
yhtäältä Suomen eri alueiden (sisävesi- ja merialueet) välillä ja toisaalta Manner-Suomen ja Ahvenanmaan välillä.

\subsubsection{Kansainväliset kokemukset}

Lainvalmistelija ei ole esityksessään viitannut tutkineensa, onko vastaavaa veroa käytössä missään muussa maassa ja millaisia kansainvälisiä kokemuksia veneveroista on ollut. Hyvän lainvalmisteluprosessin tulisi sisältää asiaa koskevien kansainvälisten kokemusten selvittäminen sekä oikeusvertailu ainakin Suomen kannalta keskeisimpien valtioiden osalta.

Kansainväliset kokemukset eivät tue veneveron käyttöönottoa. Finnboat selvitti asiaa joulukuussa 2016 venealan kansainvälisen kattojärjestön ICOMIAn (The International Council of Marine Industry Associations) kautta. Sen jäsenkuntaan kuuluu kaikkiaan 35 maata, ja jäseninä ovat käytännössä kaikki maailman veneteollisuusjärjestöt ja järjestöjen jäsenyyden kautta alan yrittäjät. Saatu tieto on siis otokseltaan käytännössä erittäin kattava. Kysely tehtiin sähköpostilla.

Selvityksestä voi todeta, että erilaisia ja erimuotoisia veneveroja on käytössä vain kahdessa maassa: Turkissa ja Espanjassa. Näistäkin Turkki on tästä verosta luopumassa, koska vero on selvityksen mukaan vahingoittanut alaa ja kääntynyt itseään vastaan. Turkin vero perustuu veneen pituuteen, Espanjassa vero perustuu kertaluonteiseen $12 \%$ :n rekisteröintiveroon yli 8 metrin veneille. Keskustelu käy sielläkin kuumana veron suhteen, sillä on oletettavaa, että ilman tätä veroa valtion tulot lisääntyisivät enemmän, koska myynti kasvaisi ja sen mukana arvonlisäveron tuotto. Kreikka soveltaa monimutkaista veneen ikään sekä omistajan ikään ja kokonaisomaisuuteen perustuvaa veroa.

Erilaisia veneveroja on lisäksi ollut käytössä USA:ssa (maailman suurin veneilymaa) ja Uudessa-Seelannissa. USA:n vero vuosina 1991-1993 oli niin sanottu luksusvero. Se oli 10 \% (vain hankinnan yhteydessä) veneille, joiden hinta oli yli 100000 euroa. Vain kahden vuoden kokeilun jälkeen siitä kuitenkin luovuttiin, koska se kääntyi itseään vastaan, verokertymä jäi kauas suunnitellusta, ja alan toimintakyky alkoi heiketä. Uudessa-Seelannissa oli 1970-luvulla käytössä 
luksusvero (20\%). Se miltei tuhosi alan teollisuuden muutamassa vuodessa ennen kuin se poistettiin. Uusi-Seelanti on nykyisin erittäin merkittävä veneteollisuusmaa. Norjassa oli käytössä moottoreille niin sanottu hevosvoimavero, jolla haluttiin kompensoida moottorien ympäristövaikutuksia. Kyseessä oli oston yhteydessä peritty erillinen kertaluonteinen vero, josta kuitenkin luovuttiin vuonna 2014, koska se oli hallinnollisesti kannattamaton ja hankalasti toteutettava.

Myös Italiassa päätettiin vuonna 2011 yrittää paikata valtion kassan vajausta veneverolla. Veron seurauksena Italiasta hävisi vuodessa 20000 veneteollisuuden työpaikkaa, polttoaineen myynti romahti $40 \%$ ja venesatamien tulot $20 \%$, ja veneilyyn yhteydessä olevien ravintoloiden, baarien ja autovuokraamojen tulot pienenivät merkittävästi. Muutamassa vuodessa saatiinkin italialaisten venevalmistajien kotimaanmyynti romahtamaan $47 \%$ :sta $7 \%$ :n osuuteen myynnistä. Voittajiakin tuli, kun 40000 Italiassa rekisteröityä venettä siirrettiin muualle, erityisesti Kroatiaan ja Korsikalle. Verolla piti kerätä Italian valtiolle 155 miljoonaa euroa vuodessa, mutta tulos jäi murto-osaan tästä. Vero oli lisäksi kallis ylläpitää ja aiheutti lähinnä negatiivisia vaikutuksia, joten se peruttiin.

\subsubsection{Lainvalmistelun laatu ja jatko}

Esitys on puutteellinen erityisesti ehdotetun veneveron verotuottovaikutusten, veneveron käytännön toteutukseen liittyvien näkökohtien ja kansainvälisen vertailun osalta. Oikeuskansleri on toistuvasti kiinnittänyt huomiota lainvalmistelun laatuun ja hyvän lainvalmistelun periaatteisiin. Hän on pitänyt erityisen huolestuttavana sitä, että kiire ja poliittinen paine saattavat syrjäyttää hyvän lainvalmistelun periaatteet. Veneveroa koskevan esityksen valmistelu ja voimaantuloaikataulun tiukkuus ilmentävät juuri oikeuskanslerin huolta kiireestä ja poliittisesta paineesta, joka tämän veron toteuttamiseen ja käyttöönottoon liittyy.

Hallituksen olisi luovuttava veneveron valmistelusta. Jos valmistelua päätetään jatkaa, esitettyjen näkökohtien huomioiminen edellyttää laajaa jatkovalmistelua hyvän lainvalmistelun periaatteiden mukaisesti. 
Mikäli esitys vietäisiin nykyisessä muodossa eduskuntaan, tämän tulisi palauttaa hallituksen esitys uuteen valmisteluun. Kulkuvälineiden verohistoriassa näin ei kävisi ensimmäistä kertaa. Vuonna 1920 automobiileista ja moottoripyöristä suoritettavaa leimaveroa koskeva hallituksen esitys ei mennyt ensi yrittämällä läpi valtiovarainvaliokunnasta, koska esitys ei ollut kaikissa tapauksissa kohtuullinen, asiantuntijat kyseenalaistivat verollepanon teknisen puolen ja lisäksi ei ollut riittävästi pohdittu vaihtoehtoisten kulkuneuvojen, kuten yksinomaan huvitarkoituksiin käytettyjen moottoriveneiden, saattamista verolle. Valtiovarainvaliokunta totesi silloin: "Hallituksen esitys on näyttänyt siksi puutteelliselta valmistellulta, ettei valiokunta ole voinut sitä hyväksyä" (HE 43/1920 siihen liittyvine mietintöineen). Vuonna 1921 hallituksen esitys muutoin hyväksyttiin mutta veneveron osalta todettiin, että "niitä valmistuksia, joita tämän veron on katsottu vaativan, ei vielä ole saatu suoritetuiksi. Valiokunta odottaa, että hallitus ensi tilassa antaa eduskunnalle esityksen kohtuullisen veron panemisesta näillekin moottorikulkuneuvoille" (HE 32/1921 siihen liittyvine mietintöineen). Venevero lienee sittemmin haudattu juuri sen tarkoituksenmukaiseen toteuttamiseen liittyneiden ongelmien takia.

\subsection{Suomen Purjehdus ja Veneily ry}

Yhdistys piti ongelmallisena veron kohdistamista yhteen harrastukseen, joka tapahtuu jo verotetuin välinein ja tuottaa valtiolle välillisesti verotuloja ja jolla on yhteiskunnallisesti työllistävä vaikutus. Kaavailtu vero ei ole määräytymisen osalta yhdenvertainen ja selkeä. Käytettävissä olevat rekisterit ovat epäluotettavia ja alun perin tarkoitettuja muuhun kuin verotukselliseen käyttöön. Veron vaikutus veneilijöiden käyttäytymiseen olisi merkittävämpi kuin kaavaillun verorasitteen voisi arvioida olevan. Veron perusteita ja veronmaksun määräytymisen perusteita ei voida pitää oikeudenmukaisina, yhdenvertaisina eikä eri harrastuksia tasapuolisesti kohtelevina. Lisäksi huvikäyttöä koskeva vero tulisi kohdistumaan monen kansalaisen elinkeinoon, ammatinharjoittamiseen tai päivittäiseen liikkumiseen. Puutteelliset 
rekisterit ja veron suorittamisen valvonnan vaikeus johtaisivat tilanteeseen, jossa osa veneilijöistä ei maksaisi veroa.

Veneilyalan liikevaihto Suomessa on 600-700 miljoonaa euroa vuodessa, ja veneveron seurauksena se pienenisi arvioilta 5-10\%. Valtio kerää veneilystä nykyään vuosittain käyttökulujen verotuksen ja arvonlisäverotuksen kautta noin 300 miljoonaa euroa. Menetykset verokertymissä (alv, tulo- ja palkkaverot sekä polttoaineverot) olisivat vähintään 15 miljoonaa euroa vuodessa.

Esitys yhden alan ja harrastuksen pisteverotuksesta ei täytä hyvän veropolitiikan periaatteita ja verotuksen neutraalisuutta, ja se tulisi toteutuessaan aiheuttamaan valtiolle vähentyneen kulutuksen, heikentyneen työllisyyden ja maamme rajojen ulkopuolelle siirtyvän aktiivisuuden kautta negatiivisen tulonkertymän. Veneverolakia ei pitäisi säätää.

Veron määräytymisen ja veron suuruuden pitäisi perustua johonkin yksiselitteiseen ja helposti todennettavaan tekijään. Moottoriteho on ilmeisesti ainoa käytettävissä oleva kriteeri, joskaan ei erityisen hyvä.

Mikäli verolla halutaan olevan ympäristövaikutuksia, voidaan moottoritehon ajatella korreloivan polttoaineen kulutukseen ja sen myötä hiilidioksidipäästöihin. Käytännössä niin ei kuitenkaan tapahdu. Todelliseen ympäristökuormitukseen vaikuttavat muun muassa veneen kulutus per meripeninkulma, vuotuinen ajosuorite ja moottorin todelliset päästöt, joten ympäristön kannalta paremmin ohjaavaan verotukseen päästään nykyisen polttoaineveron kautta. Veneilyn aiheuttama ympäristökuormitus on kaiken kaikkiaan erittäin vähäistä. Moottoritehoon perustuva veron määräytyminen luonnoksessa suunnitellulla tavalla aiheuttaisi tilanteen, jossa moni hyvinkin iäkäs pienehkö ja arvoltaan vähäinen vene olisi yhtä suuren verorasituksen kohteena kuin satojatuhansia euroja maksava uusi moottorijahti.

Suomalainen venekalusto on vanhahkoa ja vaatimatonta: venerekisterissä olevien veneiden keski-ikä on 23 vuotta, ja niiden keskimäräinen markkina-arvo jäänee reilusti alle 10000 euron. Näille veneille vuotuinen verorasitus olisi niiden arvoon verrattuna kohtuuton. Veneiden käyttö rajoittuu keskimäärin alle kymmeneen päivään vuodessa, rekisterivelvoitteen alaisilla perämoottoriveneillä vain noin 20 tuntiin vuodessa. Veron päiväkohtainen kustannus nousisi siis korkeaksi. 
Venerekisterissä olevista suuritehoisista moottoriveneistä osa on meripelastuksen, palo- ja pelastustoimen sekä muiden viranomaisten käytössä tai saaristolaisten yhteysliikenteessä. Venerekisterissä arvioidaan olevan noin 1000 pelastustoiminnassa käytettävää venettä.

Isojen huvikäytössä olevien moottorijahtien määrä on vähäinen, muutamia satoja. On todennäköistä, että niistä moni tultaisiin jatkossa siirtämään ulkomaiselle yhtiölle. Jatkossa isommat veneet todennäköisesti hankittaisiin ulkomaisilta leasingyhtiöiltä. Uusia yli 10-metrisiä moottoriveneitä maassamme myydään vain kymmenkunta vuodessa.

Käytännössä verorasitus kohdistuisi pitkälti tavallisten kansalaisten verotetuilla tuloilla hankkimiin melko vaatimattomiin harrastus- ja kulkuvälineisiin. Tämä kehitys ei olisi myöskään toivottavaa puolustusvalmiutemme kannalta, sillä huviveneiden alusotolla on oma roolinsa poikkeusolojen varautumissuunnittelussa.

Perustelu verotuksen oikeudenmukaisuudesta yli 9-metristen alle 38 kilowatin tehoisten veneiden kohdalla on epälooginen. Näitä veneitä arvioidaan meillä olevan noin 9000 . Huviveneen rungon pituudelle on virallinen huvivenestandardin määritelmä, mutta veneiden myyjillä on ollut tapana ilmoittaa veneiden kokonaispituus, johon sisältyvät mahdolliset rungon ulkopuolella olevat uimataso, ankannokka ja kaiteet. Näin ollen monella veneellä on venerekisterissä virheellinen tai arvioitu pituusmitta. Nämä veneet tulisi näin ollen tarkistusmitata.

Tähän ryhmään kuuluvat myös useat saaristolaisten perinteiset "fiskarit" sekä monet vanhat pitkät ja kapeat klassikkopurjeveneet. Monet näistä purjeveneistä ovat moottorittomia tai varustettuja pienellä apumoottorilla tuulen tyyntymisen varalta. Niiden osalta ainakaan polttomoottorin ympäristöpäästöt eivät voi olla oikeudenmukainen peruste.

Suurella osalla pienellä moottorilla varustetuista yli 9-metrisistä purjeveneistä pääasiallisena käyttönä ovat matka- ja avomerikilpailut sekä niihin harjoittelu. Kilpailuihin osallistuvat veneet tulee voida siirtää vesitse kilpailupaikoille ilman veronalaisuutta. Ahvenanmaan venerekisterissä näitä veneitä ei nykyäänkään ole. Verotuksen tulee kohdistua yhdenmukaisin perustein sekä Manner-Suomen että Ahvenanmaan veneisiin. 
Pelkästään pituuden mukaan verotettavista veneistä tulisi verotuottoa ehkä hieman yli puoli miljoonaa euroa, mutta erityisesti näiden veneiden osalta verotuksen yhdenvertaisuus, oikeudenmukaisuus ja tasapuolisuus olisivat hyvin kyseenalaisia. Lisäksi veronkannon kustannukset puutteellisten rekistereiden vuoksi nousisivat suuriksi tuottoon nähden.

Merilaki tunnistaa yli 12 metriä pitkät ja yli 24 metriä pitkät alukset. Uusi kansallinen määräys yli yhdeksän metriä pitkien veneiden verokohtelusta ei olisi yhteneväinen kansainvälisen lainsäädännön kanssa. Tämä saattaisi myös uusien veneiden myyjät ja maahantuojat eriarvoiseen asemaan. On hyvin oletettavaa, että kotimainen veneteollisuus ryhtyisi tekemään 8,90 metriä pitkiä hyvin leveitä 37 kilowatin koneteholla varustettuja veneitä. Tämä kehitys ei olisi toivottavaa vesiliikenteen turvallisuuden eikä kansainvälisen kaupan esteiden poistamisen kannalta.

Suomessa ei ole luotettavia rekistereitä veneistä. Rekisterit ovat muodostuneet vuosien kuluessa veneiden omistajien omista ilmoituksista, ja tietojen oikeellisuuden tarkistaminen ei ole ollut kovin tarkkaa. Veneiden pituudet ja konetehot on ilmoitettu omistajan parhaan tietämyksen perusteella. Myytyjä ja tuhoutuneita veneitä ei välttämättä ole poistettu rekisteristä, joten sama, eri maistraattien alueelle edelleen myyty vene voi esiintyä rekistereissä eri rekisteritunnuksilla useaan kertaan. Moottorien vaihtoja ei ole välttämättä päivitetty rekisterinpitäjälle.

Merkittävää osaa käytössä olevista veneistä ei valmistaja ole merkinnyt millään tunnuksilla. Käytännössä vasta 16.6.1998 jälkeen käyttöön otetut CE-merkityt veneet on varustettu yksilöinnin mahdollistavalla valmistenumerolla.

Veneiden omistuksen siirtoa, kuten muunkaan irtaimen kauppaa, ei ole aikaisemmin vaadittu tekemään kirjallisesti. Näin ollen vanhemmista veneistä ei ole myöskään kauppakirjoja tai vastaavia omistuksen todentavia asiakirjoja.

Puutteidensa, virheellisten tietojensa ja tuplarekisteröintien takia venerekisteri ei sovellu veneveron verotustietojen pohjaksi. Rekisterissä on arvioiden mukaan 10-20\% niin sanottuja haamuveneitä ja lisäksi paljon puutteellisia ja virheellisiä tietoja. Yksi venerekisterin ylläpidon peruste on ollut veneilyturvallisuus ja sen hyöty pelastustoi- 
mille. Nyt kansalaiset kiihtyvällä vauhdilla poistavat veneitään venerekisteristä. Vuoden 2016 aikana venerekisteristä on poistettu yli 4000 venettä. Poistamisen perusteluina esitetään, että vene ei tule olemaan ensi kaudella käytössä. Todennäköistä on, että jatkossa liikenteessä tulee olemaan tällaisia rekisteristä poistettuja veneitä. Saaristolaisilla ja saariston mökkiläisillä on monesti useita yhteysveneitä, joista osa nyt poistetaan rekisteristä. Tällainen kehitys on veneilyturvallisuuden kannalta valitettavaa.

Esityksessä mainitaan rekisteriin voitavan tallentaa merkintä veneen katsastamisesta. Onko lakiesityksellä samalla tarkoitus antaa Trafille mahdollisuus määrätä huviveneet katsastettaviksi? Tuleeko tämä aiheuttamaan lisää kustannuksia veneilijöille? Katsastus olisi käytännössä mahdotonta tehdä niin, että siitä olisi kenellekään hyötyä. Vesiliikenteen turvallisuuteen liittyvän vesikulkuneuvorekisterilain muuttaminen ajoneuvoliikennerekisterilain kaltaiseksi laiksi ei edistä vesiliikenteen turvallisuutta vaan vaarantaa sitä.

Verovalvonta tulisi olemaan haasteellista. Maassamme on paljon sellaisia vesistöjä, joissa kaavailluilla valvontaviranomaisilla Poliisilla, Tullilla ja Rajavartiolaitoksella ei olisi valvontaan resursseja eikä tarvittavaa kalustoa. Verotettavista veneistä vain osa on julkisissa venesatamissa, joten valvonta tulisi kohdistaa vesille. Tiettyjen vesistöjen alueilla valvonta tulisi olemaan niin epätodennäköistä, että verolain kunnioitus voisi joutua koetukselle.

Veneily on maamme tuhansien järvien ja jokien sekä rikkonaisen rannikkolinjan ansiosta koko kansan harrastus tulo- ja sosiaaliluokkiin katsomatta. Veneilytaidot ovat kansalaistaitoja, joiden kehittymistä tulisi tukea. Veneily on liikuntamuoto, jota voi harrastaa usea sukupolvi yhdessä. Suomi on maantieteellisestä sijainnistaan huolimatta johtavia olympiapurjehduksen ja nopeuskilpaveneilyn maita. Purjehdus on mitalein mitattuna parhaita kesäolympialajejamme. Laji kannustaa tavallisia kansalaisia ylläpitämään kuntoaan ja aktiivista elämäntapaa.

Joskus liikkuminen huviveneellä on olosuhteiden takia myös ainoa kulkuyhteys kouluun ja töihin. Saaristossamme huviveneillä liikkuvat niin nuohooja kuin rakennusmiehetkin.

Erityisesti saariston elinvoimaisuuden turvaamisen kannalta vero on kyseenalainen. Veneilyn harrastekyselyissä on nähtävissä nuorem- 
man aikuisväestön selvästi vähentynyt kiinnostus veneilyyn. Uusi vero tulisi lisäämään vapaa-ajan aktiviteettien suuntautumista muihin harrastuksiin, monesti mitä ilmeisimmin lomailuun ulkomailla. Tällöin veneilystä pois siirtyvä kotitalouksien kulutus ei jäisi kansantaloutemme kiertoon.

Epäselvien perusteiden ja epäluotettavien rekistereiden vuoksi tämän veron kantokustannukset nousisivat tavanomaista suuremmiksi. Vähentynyt veneiden käyttö ja veneistä luopuminen vähentäisivät kotimaan matkailua, mikä tuntuisi erityisesti Järvi-Suomessa ja rannikolla. Veneilyharrastuksen vähentyminen ja suurempien veneiden lippuvaltion vaihtuminen pienentäisivät venetelakointi- ja korjauspalvelujen käyttöä. Uudet suuremmat veneet ostettaisiin jatkossa mahdollisesti ulkomaisten yhtiöiden nimiin, jolloin valtio ei saisi niiden osalta valtio arvonlisäverokertymää ja todennäköisesti myös kotimainen veneteollisuus menettäisi ostajia.

Vähentyneen arvonlisävero-, polttoainevero- ja tuloverokertymän lisäksi verolla saattaisi olla negatiivisia työllisyysvaikutuksia. Finnboatin 280:ssä jäsenyrityksessä työskentelee noin 3500 suomalaista. Uusien veneiden ja moottoreiden myynti tuottaa valtiolle noin 60 miljoonaa euroa arvonlisäveroja vuodessa. Kyselyjen mukaan keskimääräinen veneilijä käyttää vuodessa veneilyyn runsaat 2500 euroa, josta valtion verokertymä on yli 950 euroa.

Venevero tulisi laskemaan valtion kokonaisverokertymää ja aiheuttamaan negatiivisia vaikutuksia matkailulle, työllisyydelle, suomalaiselle venealalle sekä yhdelle aktiivisuutta ja liikuntaa lisäävälle harrastukselle. Vero vaikuttaisi kuten haitta- tai pisteveron yleensä on tarkoitus vaikuttaa: se ohjaisi kansalaisten käyttäytymistä. Koko veneala tuottaa valtiolle nykyään suoranaisia verotuloja 260-300 miljoonaa euroa vuodessa. Veron taloudellinen vaikutus sen sijaan olisi yhteiskunnalle negatiivinen.

Ruotsissa kokeiltiin veneveroa mutta sen tuotto jäi niin alhaiseksi, että siitä luovuttiin. Suomen venekanta on huomattavasti vaatimattomampi ja pienempi kuin Ruotsissa.

Esitys ei yhdistyksen mielestä täytä hyvän veropolitiikan periaatteita eikä verotuksen neutraalisuutta. Vero tulisi aiheuttamaan valtiolle vähentyneen kulutuksen, heikentyneen työllisyyden ja maamme rajojen ulkopuolelle siirtyvän aktiviteetin kautta negatiivisen tulokertymän. 


\subsection{Suomen Meripelastusseura ry, Ålands Sjöräddningssällskap ja palokunnat}

Suomen Meripelastusseura ry (SMPS) omistaa 134 rekisteröityä ja katsastettua meripelastusalusta, jotka ovat käytössä sen 57 jäsenyhdistyksessä maamme meri- ja järvialueilla. SMPS suorittaa yhteiskunnallisesti merkittävää pelastus- ja avustustehtävää, ja sillä on keskeinen rooli Suomen meri- ja järvipelastuksessa Rajavartiolaitoksen ja muiden viranomaisten tukena ja yhteistyökumppanina. SMPS ja sen jäsenyhdistykset hoitavat merialueilla toiseksi eniten pelastus- ja avustustehtäviä heti Rajavartiolaitoksen jälkeen. Sisävesillä SMPS:n jäsenyhdistyksillä on yhtä suuri tai jopa suurempi tehtävämäärä kuin viranomaisilla.

Rajavartiolaitoksen johdolla suoritettavien meripelastustehtävien määrä on vuositasolla yhteensä noin 1 500-2 000 tehtävää. Niistä on vapaaehtoisten meripelastajien suorittamia noin 20-25\%. Lisäksi SMPS:ään kuuluvat paikallisyhdistykset osallistuvat sisävesillä lähes yhtä moneen viranomaisen johdolla suoritettuun pelastustehtävään joka vuosi. Todennäköiseltä menehtymiseltä SMPS pelastaa vuosittain noin 30-50 henkilöä. Vuoden 2016 pelastustehtävistä hälytys SMPS:n yksiköille tuli 668 kertaa joltakin viranomaiselta (meripelastuskeskus, hätäkeskus, Poliisi, pelastuslaitos, merivartiosto). Kaikkiaan SMPS:n alukset suorittivat 1590 pelastus- ja avustustehtävää, joissa apua sai 3464 ihmistä. Avun kohteena oli 1312 alusta. Yksistään vuonna 2016 SMPS:n suorittamien pelastustehtävien suorittaminen vaati 10148 henkilötyötuntia.

Osaamisen ja valmiuden ylläpitämiseksi SMPS:n 57 pelastusyksikköä harjoittelevat säännöllisesti. Valmiuden ylläpito 24/7-periaatteella koko avovesikauden ajan sitoo miehistöjä keskimäärin noin 200 päivää vuodessa. Kun tämä valmius sekä tehtäviin ja harjoitteluun käytetty aika muutetaan "työtunneiksi", saadaan yhteiseksi tuntimääräksi keskiarvoisella 3,5 henkilön valmiusasteella 957600 h/ vuosi (57 yhdistystä x 24 h x 200 vrk x 3,5 hlöä). Koska kaikki tämä työ tehdään täysin vapaaehtoisvoimin, SMPS:n alaisesta vapaa- 
ehtoistyöstä koituu yhteiskunnallisesti laskennallinen yli 20 miljoonan euron hyöty vuosittain.

SMPS rahoittaa toimintansa sekä Raha-automaattiyhdistyksen (nyk. Veikkaus) tuotoista myönnettävillä avustuksilla että jäsenmaksutuloilla ja lahjoituksilla. Lisäksi se esimerkiksi vuonna 2016 sai vuosiavustuksena Rajavartiolaitoksen budjettivaroista 204000 euroa. SMPS:n vuosibudjetti on noin 3-3,5 miljoonaa euroa, josta valtaosa käytetään pelastusveneiden hankintaan, korjauksiin, ylläpitoon ja turvavarustehankintoihin sekä koulutukseen.

Meripelastuslain mukaan Rajavartiolaitos on johtava meripelastusviranomainen, ja se käyttää meripelastustoimessa apunaan SMPS:ään kuuluvia meripelastusyhdistyksiä. Näiden käyttämät meripelastusalukset on virallisesti hyväksytty kansainvälisten meripelastusta koskevien sopimusten mukaisesti etsintä- ja pelastusyksiköiksi Rajavartiolaitoksen suorittamalla katselmoinnilla. Rajavartiolaitoksen mukaan meripelastuslaissa tarkoitetun meripelastustoimen suoritustaso edellyttää toimivaa ja kattavaa vapaaehtoisten meripelastusseurojen alusyksikköjen valmiudessaoloa, ja alusyksiköillä täydennetään Rajavartiolaitoksen ja muiden toimintaan osallistuvien viranomaisten tuottamaa palvelua.

SMPS piti veneveroehdotuksen kohdistumista vapaaehtoisten meripelastusjärjestöjen pelastusaluksiin edellä oleviin seikkoihin viitaten erittäin huonona ja edellytti yhdenvertaisuuden vuoksi meri- ja järvipelastukseen käytettävien alusten rajaamista veneveron ulkopuolelle Rajavartiolaitoksen alusten tavoin. Veron määräämisellä olisi vesillä tapahtuvaan pelastustoimeen negatiivisia vaikutuksia johtuen veron aiheuttaman taloudellisen taakan lisäyksestä. Ehdotetussa muodossaan vero tarkoittaisi noin 34000 euron vuosittaista lisäkulua SMPS:Ile. Tämä lisälasku voi johtaa SMPS:n toiminnan supistamiseen, ja vapaaehtoisen pelastustoiminnan hankaloittaminen tai supistaminen ei liene yhteiskunnan etu.

Hallitusohjelman tavoitteena on helpottaa vapaaehtoistoimintaa. Esitetty ehdotus ei ole linjassa tämän tavoitteen kanssa. Pelastusalusten verottamisesta koituva fiskaalinen hyöty valtiolle olisi vähäinen, mutta yksittäiselle 134 aluksella vapaaehtoista pelastustoimintaa harjoittavalle toimijalle verosta aiheutuva haitta olisi hyvin merkittävä. Esityksen jatkovalmistelussa olisikin tärkeää arvioida panos-tuotto- 
suhdetta pelastusalusten veronalaisuuden osalta. Pelastusalusten rajaaminen veron ulkopuolelle tuottaa yhteiskunnallista hyötyä, kun varat silloin voidaan veneveron sijasta käyttää pelastus- ja valistustoimintaan.

Vapaaehtoisten meripelastusseurojen alusten erityisasema ja erityistehtävät on jo aikaisemminkin tunnistettu useissa säädöksissä, ja pelastusalukset on jätetty lakien soveltamisalan ulkopuolelle. Pelastusalukset suorittavat yhteiskunnalle ja kansalaisille tärkeää humanitaarista tehtävää. Maapuolella vastaavaa toimintaa harjoittavat pelastus- ja sairasautot, jotka on vapautettu suunniteltua veneveroa vastaavasta ajoneuvoverosta. Ei siis ole perusteltua kohdella samantyyppistä yhteiskunnallisesti tärkeää toimintaa suorittavia kulkuneuvoja verotuksellisesti eri tavoin sen mukaan, liikkuuko kulkuneuvo maalla vai vedessä. SMPS:n alukset on merkitty Trafissa ammattiveneiksi. Veneet on lisäksi rekisteröity SMPS:n omassa rekisterissä, ja ne ovat siten tarvittaessa helposti yksilöitävissä veneverosta vapautettaviksi. Meripelastusseurojen alukset on siis mahdollista rajata veneverolain ulkopuolelle täsmällisesti ja tarkasti.

Allands Sjöräddningssällskap (ASRS) puolestaan lausui, että veneveroesitys on syvästi epäoikeudenmukainen saariston ja rannikon asukkaille sekä suoraan vahingollinen venematkailijoiden kansalliselle ja kansainväliselle turismille. Esitys iskee voimakkaammin rannikkoon ja saaristoon, jossa ruotsinkielisten osuus on suurempi kuin muualla maassa. Esityksen seuraukset ovat epäoikeudenmukaisia, koska vanhempia hyötyveneitä verotetaan ankarammin kuin uudenaikaisia huviveneitä, joiden koneteho on 50 hevosvoimaa tai vähemmän. Erityisen onnetonta ÅSRS:n mukaan on, että sen ja muiden vastaavien organisaatioiden veneitä ehdotetaan verolle. ÅSRS:n toiminta perustuu vapaaehtoisuudelle, joten vero veneille, joita käytetään ihmishenkien pelastamiseen, on epäsuorasti vero yhdistystoiminnalle ja aatteelliselle työlle. Se olisi äärimmäisen onnetonta sitä taustaa vasten, että koko maan pitäisi kannustaa vapaaehtoista työtä eikä rangaista siitä.

Veron perimisestä tulisi äärimmäisen byrokraattista. Työpaikkoja voidaan menettää, saaristomatkailu kärsii ja valvonta on äärimmäisen haastavaa. Venevero ei kohdistuisi eniten "herrojen huvijahteihin", vaan eniten joutuisivat maksamaan tavalliset palkansaajat ja eläkeläiset. 
ÅSRS tekee parhaillaan suurta katsausta ahvenanmaalaisista vierassatamista luodakseen paremmat edellytykset veneturismille, joka on hyväksi koko maan elinkeinoelämälle - erityisesti harvaan asutuille seuduille, joilla yrittäminen on haastavaa. Venevero uhkaa vähentää kiinnostusta venematkailuun, mikä olisi kohtalokasta niille seuduille, jotka enemmän kuin muut tarvitsevat turistinsa. Veneverohanke on romutettava, ja on sen sijaan kannustettava kestävää veneilyä merillä ja tuhansilla järvillämme. Veneily on tervehenkistä toimintaa, ja matkailuelinkeinolla on maasamme suuret mahdollisuudet.

Suomen Sopimuspalokuntien Liitto ry vaati lausunnossaan, että pelastustoimeen ja öljyntorjuntatehtäviin käytettävät veneet ja vesikulkuneuvot olisi rajattava veneverosta vapaaksi, samalla tavalla kuin verosta olivat vapaita lakiluonnoksessa Puolustusvoimien ja Rajavartiolaitoksen vastaavat veneet. Pelastustoimeen ja sen piirissä toimiviin yleishyödyllisiin yhdistyksiin kohdistuva veneverolaki saattaisi vaikuttaa turvallisuuteen ja vähentää tarpeellista venekalustoa. Vapaaehtoiset palokuntayhdistykset ylläpitävät VPK-sopimuspalokuntia, joiden talous kestää huonosti uusia lakisääteisiä kustannuksia.

\subsection{Venepuuseppä}

Venepuuseppä $A$. Vaittinen totesi pääasiallisen toimeentulonsa tulevan veneiden korjauksesta. Kevätkiireiden aikaan hän yleensä työllistää itsensä lisäksi yhden tai joskus kaksi kausityöntekijää. Asiakkaat ovat tyypillisesti iäkkäämpiä tai kiireisiä veneilyn harrastajia, jotka ylläpitävät vanhaa mutta hyväkuntoista venettä. He ovat tavallisesti keskituloisia palkansaajia tai eläkeläisiä, jotka säästävät koko syksyn ja talven teettäk̈kseen veneelleen tarvittavat keväthuollot ja korjaukset. Asiakkaista suurin osa pohtii, onko veneharrastuksessa ja veneen omistamisessa mitään järkeä, kun kustannukset per käyttötunti ovat lyhyen kesämme vuoksi hyvin korkeat. Veneily Suomessa on suojaisten vesistöjemme ansiosta suhteellisen matalan kynnyksen harrastus; pienemmillä ja vanhemmillakin veneillä pärjää meidän vesillämme.

Veneily on pääasiassa keskituloisten eläkeläisten ja perheiden yhteinen ulkoilu- ja retkeilyharrastus. Nämä ryhmät joutuvat jo nyt säästämään muun osan vuotta voidakseen haluamallaan tavalla matkailla 
ja harrastaa kotimaassa. Hyvin monille vero olisi riittävä syy lopettaa harrastus, joka muutenkin on kallista.

Miten kansalaisten kotimaassa tapahtuvan retkeily- ja ulkoiluharrastuksen verottaminen palvelee yhteiskunnan kokonaisetua ja miten se tukee suomalaisten onnellisuutta ja hyvinvointia?

Venealalla tyypillisesti suuri osa vuoden liikevaihdosta tehdään keväällä ja muu osa vuotta pitää sinnitellä keväällä aikaansaaduilla säästöillä ja pienemmillä töillä. Jo tähänastinen veneverokeskustelu on häivyttänyt yrityksen keväälle 2017 sovituista töistä ja tilauskannasta noin $40 \%$.

Veneen omistaja laittaa veneensä ennemmin romuksi kuin alkaa maksaa siitä muiden kulujen lisäksi vielä epäoikeudenmukaiseksi koettua vuotuista veroa. Mitä hallitusohjelman tavoitteita palvelee pienyrittäjän tuomitseminen luopumaan ammatistaan ja toimeentulostaan tämän ehdotuksen myötä?

\subsection{Vesiskootteri- eli vesijettiyrittäjät}

T. Ylikännö totesi, että veneverolaki olisi syrjivä. Veneet ovat harrastus- ja vapaa-ajanviettovälineitä. Mikäli ne pannaan verolle, on kyseessä ainoa harrastus, jota verotetaan erillisellä lailla. Ensisijaisesti olisi syytä luopua koko verosta ja pyrkiä olemassa olevan veropohjan laajentamiseen valtiontalouden paikkaamiseksi.

Jos poliittisista syistä ei olisi mahdollista luopua ehdotetusta verolaista, veroa ei kuitenkaan pitäisi periä alle nelimetrisistä aluksista. Tämä rajaisi verotuksesta pois käytännössä ainoastaan vesiskootterit eikä heikentäisi veron fiskaalisia vaikutuksia liikaa. Vesiskootterien omistaminen pitäisi säilyttää verovapaana, koska nyt esitetty vero kohtelee sitä erityisen epäreilusti.

Vesiskootteri on laite, jota käytetään pääasiassa hyvien ilmojen salliessa - käytännössä silloin, kun on tarpeeksi tyyntä ja vesi on tarpeeksi lämmintä. Yleensä käyttöaika on pari viikkoa heinä- ja elokuun vaihteen molemmin puolin. Lyhyestä kaudesta johtuen vesiskootteria käytetään tyypillisesti enintään 5-10 tuntia kesässä. Vesiskoottereissa on niiden kokoon nähden suuri moottoriteho, joten useimmista vesiskoottereista maksettaisiin esityksen mukaan suurinta, 300 euron 
vuosimaksua. Tämä tekisi käyttötunnin hinnaksi 30-60 euroa tunnissa. Verorasitus käyttötuntia kohden olisi lausujan mukaan suorastaan pöyristyttävän törkeä.

Käytetyn vesiskootterin hinta on noin 3 000-6 000 euroa. Esitetty 300 euron vero olisi siis 5-10\% laitteen arvosta. Näin korkea suhteellinen veron osuus olisi liikaa jo kertaluonteisenakin, saati vuosittain perittävänä. Mikäli vesiskoottereita ei haluta kokonaan jättää verottamatta, ehdotettuja säännöksiä olisi muutettava niin, että aluksen pituus vaikuttaa veroon ja vesiskoottereille ja muille alle neljän metrin aluksille asetettaisiin sadan euron vuotuinen vero, joka sekin on korkea mutta paremmin suhteessa laitteen todelliseen käyttöön ja arvoon.

Myös $M$. Eerola otti kantaa vesijettien asemaan. Hän totesi, että mahdollisen vesijettien tehon mukaisen verotuksen tulee perustua aukottomaan tietoon moottorin tehosta; muutoin vero ei ole tasapuolinen. Suomessa on käytössä tuhansia vanhoja vesijettejä, joiden moottorin tehosta ei ole tietoa kenelläkään. Jokin oletettu teho on tarvinnut venerekisteriin ilmoittaa, jotta laite on saatu rekisteröityä. Ilmoittaja on omistaja itse; hän on saanut tehosta tiedon suullisesti myyjältä tai olettanut tehon muiden epävirallisten lähteiden perusteella. Venerekisterin pitäjä, maistraatti, ei ole tietoa tarkastanut eikä vaatinut todennusta. Ilmoitettuihin tehoihin perustuva vesijettien verotus ei ole riittävän luotettavaa asettamaan ihmisiä tasa-arvoiseen asemaan. Lisäksi tehoihin perustuva verotus houkuttelee verovilppiin, ilmoittamaan laitteista vääriä tehoja, koska tehoja ei voida todentaa. Jotta teho voisi olla verotusperuste, jokaisesta laitteesta pitää olla saatavilla valmistajan ilmoittama teho. Nyt sitä ei ole. Lausunnon antaja vaati veneveron hylkäämistä.

Myös $M$. Hiekkamäen lausunnossa todettiin lakiluonnoksen kohtelevan epäreilusti vesiskoottereita. Vesiskoottereissa on usein melko suuri moottoriteho, mutta vesiskootterit ovat kuitenkin arvoltaan melko vähäisiä. Esimerkiksi jo noin 5000 euron arvoisessa käytetyssä vesiskootterissa voi olla yli 200 hevosvoimaa, mikä tarkoittaa, että sen venevero tulisi olemaan maksimi 300 euroa vuodessa (saman verran kuin vaikkapa puolen miljoonan arvoisessa huvipurressa). Tämä on kohtuuttoman suuri vuosivero suhteutettuna laitteen vähäiseen arvoon ja siihen, että laitetta saatetaan käyttää vuodessa vain muu- 
taman tunnin ajan (tyypillisesti n. 10 tuntia kesässä). Käyttötuntien hinta muodostuisi näissä tapauksissa niin suureksi, ettei kyseisenlaisten vesiskoottereiden omistamisessa enää olisi järkeä.

Esityksen mukaan maksun määrä perustuisi veneen moottorin tehoon, joka korreloi polttoaineen kulutuksen kanssa. Tämä pätee jossain mär̈rin veneisiin, mutta se ei kohtele oikeudenmukaisesti vesiskoottereita. Nykyaikainen nelitahtinen vesiskootteri kuluttaa polttoainetta vähemmän kuin samantehoinen vene, koska sillä ei ole suurta massaa työnnettävänään ( $j a$ näin ollen vesiskootteri saastuttaa vähemmän). Itse asiassa moni nykyaikainen vesiskootteri ei kuluta polttoainetta sen enempää kuin pienehkö moottorivene, josta sen pienen moottoritehon takia ei välttämättä jouduttaisi maksamaan veroa ollenkaan.

Moottoriteho ei korreloi polttoaineen kulutukseen, mikäli verrataan venettä ja vesiskootteria. Lisäksi vesiskootterien käyttämän propulsion hyötysuhde on paljon huonompi kuin perämoottoreissa (mikä kompensoidaan suuremmalla moottoriteholla), joten vesiskootterin moottorin hevosvoimien määrä veron perusteena on (veneisiin nähden) epäreilu. Vesiskoottereilla tulisi olla erilainen verotaulukko kuin veneillä luontaisesti suuremman tehon ja pienemmän kulutuksen (myös pienemmän arvon) vuoksi. Vesiskoottereita on Suomessa niin vähän, että niiden verokertymä olisi lähes merkityksetön. Suunniteltu ankara verotus johtaisi vain siihen, että lajin harrastaminen vähenisi tai kuolisi kokonaan. Tämä taas tarkoittaisi valtiolle verotulojen menetystä pienemmän arvonlisäverokertymän kautta ja esimerkiksi polttoaineen myynnin vähentymisen kautta.

Asiasta lausui myös Sydän-Hämeen Safarit $O y$, jonka päätuote ovat vesijeteillä, moottorikelkoilla ja mönkijöillä tapahtuvat ohjatut turvalliset safariretket. Oheistuotteena yhtiö järjestää verkoston kautta ryhmille myös sauna-, kuljetus-, majoitus- ja ateriapalvelut. Veneveron vaikutus ohjelmapalveluita tuottavan yrityksen talouteen tulisi olemaan kohtuuton. Verolla olisi taannuttava vaikutus kotimaan matkailuun. Hallitus lupasi kautensa alussa, että se ei tule nostamaan pienyrittäjän maksuja. Kaavailtu vero aiheuttaisi yhtiölle, kotimaan matkailun mikroyritykselle, kohtuuttoman suuren kaksinkertaisen verotuksen. Yhtiö maksaisi veroa lopputuotteesta ja veneveroa kalustosta, jolla se tekee tätä työtä. Sillä on 16 rekisteröitävää vesi- 
jettiä, joista jokaista verotettaisiin keskimäärin 250 euroa/vuosi, siis yhteensä 4000 euroa vuodessa. Verollinen laskutus vesijettisafarien osalta oheispalveluineen vuonna 2016 oli noin 35000 euroa, joten suunniteltu vero tulisi olemaan vesiskootterisafarien osalta runsaat $11 \%$ verollisesta vuotuisesta laskutuksesta. Veneveroa ei tulisi soveltaa ammattimaiseen käyttöön matkailu- ja ohjelmapalvelualoilla, tai vaihtoehtoisesti vero olisi hyvitettävä takaisin.

\subsection{Venekerhot}

Helvene on helsinkiläisten, lähes 80 venekerhon kommodorien kokouksessaan vuosittain valitsema yhteenliittymä, jonka tehtävänä on yhteistoiminta Helsingin kaupungin kanssa ja veneilyn harrastamisen kaikinpuolinen edistäminen. Helvene totesi lausunnossaan, että esitys ei täytä hyvän veropolitiikan periaatteita, verotuksen neutraalisuutta eikä edes taloudellisia tavoitteitaan. Veron vaikutukset olisivat hyvin laajalti yhteiskunnallisesti ja taloudellisesti erittäin negatiiviset muun muassa sitä kautta, että ne suuresti heikentäisivät kotimaista kulutusta ja työllisyyttä.

Vakavin ongelma esityksessä kohdistuu perustuslaissa turvatun kansalaisten yhdenvertaisuuden toteutumattomuuteen. Lisäksi esitys toteutuessaan oleellisesti heikentäisi koko veneilyharrastusta ja kaikkea siihen liittyvää toimintaa. Veron haitalliset vaikutukset veneturvallisuuteen olisivat äärimmäisen huolestuttavat. Veneilyn verotusta on merkittävästi korotettu jo sillä, että polttoöljyn käyttö kiellettiin ja veneilijät pakotettiin käyttämään raskaasti verotettua dieselpolttoainetta.

Trafin venerekisteriä ei ole aikoinaan määritelty verotuksen pohjana käytettäväksi. Tästä seuraa lukuisia perustavanlaatuisia ongelmia. Kyse on rekisteristä, jota maistraatit aikoinaan ylläpitivät veneiden omistajien ilmoituksiin perustuvana. Jo rekisterin siirtyessä Trafille todettiin, ettei se ole luotettava. Trafi ainoastaan kirjasi maistraattien rekisterit mutta ei ole ryhtynyt rekisteriä tarkistamaan. Rekisterin perusteet (veneen pituus ja moottorin teho) soveltuvat rekisteröintiin mutta eivät missään tapauksessa verotukseen. Käytännössä voi esimer- 
kiksi miljoonan euron arvoinen vene kokonaan välttyä veneverolta mutta alle kymmentuhannen euron vene voi joutua verotetuksi.

Venerekisterissä on paljon vanhoja veneitä, joiden keskimääräinen ikä on noin 30 vuotta ja joista huomattava osa on jo poistunut käytöstä. Siinä on noin 200000 vesikulkuneuvoa eli moottoriteholtaan yli 20 hv:n ja/tai pituudeltaan yli 5,5 metrin venettä. Haamuveneitä on $10000-20000$.

Vaatimattomaan yhteysvene- tai kalastuskäytössä olevaan venekalustoon venevero kohdistuisi voimakkaasti. Sen piiriin tulisivat sellaisetkin alukset, joiden käyttö ei ole huviveneilyä vaan yhteiskunnallisesti merkittävää, esimerkkinä vapaaehtoinen meripelastustoiminta ja palontorjunta sekä eräät viranomaistoiminnat.

Ahvenanmaalla rekisteröinnin pituusraja on 24 metriä tai 20 hevosvoimaa perämoottoreissa ja 50 hevosvoimaa sisämoottoreissa. Ahvenanmaalla käytössä olevat erilaiset rekisteröintiperusteet johtavat siihen, että suurin osa purjeveneistä ja hidaskulkuisista sisämoottoriveneistä ei siellä ole rekisterissä. Kansalaisten yhdenvertaisuusperiaate edellyttää, että kaikki Suomen kansalaiset ovat tasapuolisessa asemassa verotusperusteiden osalta.

Veron tuoton on ilmeisesti ajateltu muodostuvan erityisesti isojen, koneteholtaan suurien veneiden maksuista. Veneilijöiden keskuudessa on jo laajalti esiintynyt ennakollista verosuunnittelua veneverolta välttymiseksi. Mahdollisesti kyseiset veneet siirtyisivät jatkossa ulkomaisten, erityisesti tätä varten ulkomaille perustettavien yhtiöiden omistukseen ja kyseisen toisen maan venerekisteriin. Asiakokonaisuuteen voitaisiin liittää veneiden talvisäilytys ulkomailla.

Ruotsissa kokeiltiin veneveroa mutta sen tuotto jäi niin alhaiseksi, että verosta päätettiin luopua. Miten tämä hanke voisi onnistua Suomessa, jossa venekanta on määrällisesti paljon vähäisempi ja ominaisuuksiltaan vaatimattomampi? 


\subsection{Matkapurjehtijat}

Merikarhut ry on Suomen suurin matkapurjehdusyhdistys. Sen 2700 jäsentä ja 1200 venettä edustavat $10 \%$ :n osuutta Suomen matkapurjehdusveneistä. Merikarhut pyrkivät sääntöjensä mukaan "herättämään ja vahvistamaan merimatkailun ja matkapurjehduksen harrastusta sekä mahdollisuuksia tällaisten matkojen tekemiseen”. Yhdistyksen toimintaan ei yleensä kuulu edunvalvonta, mutta nyt on päädytty tekemään poikkeus, koska veneverolaki vaikuttaisi hyvin haitallisesti yhdistyksen tavoitteisiin. Sekä veneilyharrastus että saariston matkailuelinkeino tulisivat kärsimään verosta.

Kyseessä olisi pistevero, joita ei ole aikoihin pidetty mielekkäinä, ellei tavoitteena ole jonkin selkeän haitan tai ei-toivotun käyttäytymisen estäminen. Mistään ei ilmene, onko nyt tavoitteena yrittää ohjata kansalaiset kohti ympäristöystävällistä toimintaa vai palata jo kertaalleen poistettuun varallisuusverotukseen, tällä kertaa tosin vain yhden yksittäisen esineluokan osalta. Veron pontimena lienee populistinen ja kateuteen perustuva tavoite lisätä niiden verotaakkaa, joilla veron ideoijien mielestä on varaa maksaa. Ikävä kyllä venevero kohdistuu myös vaatimattomaan ja satunnaisessa käytössä olevaan sekä yhteysvene- tai kalastuskäytössä olevaan venekalustoon. Lisäksi moni kalliimmankin veneen omistaja on jo kertaalleen verotetuilla tuloilla ja usein lisäksi lainarahalla saanut kokoon rahoituksen unelmiensa veneeseen, josta nyt vielä uudelleen halutaan kerätä ylellisyys- tai kateusveroa.

Suomen ja sen ympäristönsuojelun kannalta esimerkiksi polttoaineveron korotus olisi paljon perustellumpi veromuutos kuin nyt kaavailtu venevero, jossa jopa täysin päästöttömät purjeveneet joutuisivat verolle pituutensa tähden. Hyvin ikäviä tilanteita syntyy niille, joilla on omistuksessaan useita mutta arvoltaan vähäisiä ja pienellä käytöllä olevia veneitä.

Tavoitellun tuoton saaminen voi johtaa yksittäistapauksissa kohtuuttomaan verorasitukseen. Samalla verotus kohdistuu sattumanvaraisesti yhteen toimialaan ja vaikuttaa negatiivisesti alan työllisyyteen. Veneily on maassamme koko kansan harrastus, ja valtiovallan tulisi mieluummin tukea sitä kuin kurittaa. Maamme venekanta on 
hankittu jo verotetuilla tuloilla, veneistä on maksettu arvonlisävero ja niiden käytöstä valtio kerää huomattavan summan polttoaineen hintaan sisältyvänä polttoaineverona sekä arvonlisäverona.

Veron on ajateltu muodostuvan erityisesti isojen ja kalliiden, koneteholtaan suurien veneiden maksuista. Veneveron ideoijilta on vain jäänyt huomiotta se, että näitä veneitä on lukumääräisesti todella vähän, ja ne ovat usein ulkomaisten, esimerkiksi venäläisten tai virolaisten, yhtiöiden omistuksessa.

Venetoimialaan liittyvät palvelut ovat merkittävä työllistäjä. Veneverolla olisi negatiivinen vaikutus suomalaisille veneveistämöille, venesatamille, huolto- ja asennusyrityksille, telakkatoiminnalle, rantakahviloille ja monille muille palveluntuottajille, joiden asiakkaita ovat veneellä liikkujat. Veneen omistamisen kustannusten kasvu vaikuttaisi suoraan kaikkien näiden palvelujen myyntiä alentavasti ja sitä kautta pienentäisi muun muassa polttoaineveron ja arvonlisäveron kertymiä.

Ajoneuvojen (veneet mukaan lukien) käyttämään bensiiniin ja dieseliin sisältyvät verotuotot ovat vuodessa noin 4 miljardia euroa (polttoainevero 2,785 miljardia + polttoaineiden alv 1,283 miljardia). Puolen prosenttiyksikön korotus polttoaineiden veroihin kerryttäisi valtiolle noin 20 miljoonaa euroa eli enemmän kuin veneveron optimistisesti arvioitu 17 miljoonaa, eikä veron kerääminen aiheuttaisi mitään lisäkustannuksia. Kun veneveron arvioidusta bruttotuotosta vähennetään suorat ja välilliset keräämiskulut sekä otetaan huomioon arvonlisäverovelvollisten palveluiden ja polttoaineen käytön väheneminen, ollaan todennäköisesti negatiivisessa verokertymässä. Fiskaaliselta kannalta suunnitelmassa ei ole mitään järkeä.

Verotuksen tulisi kansalaisten perusoikeuksiin kuuluvan yhdenvertaisuuden vuoksi kohdella samassa tilanteessa olevia kansalaisia samalla tavalla. Maassamme ei ole luotettavia rekistereitä veneistä. Sama vene, joka useilla kaupoilla on siirtynyt maistraatin alueelta toiselle, voi esiintyä rekistereissä eri rekisteritunnuksilla useaan kertaan. Myytyjä tai tuhoutuneita veneitä ei ole välttämättä poistettu rekistereistä, eikä moottorien vaihtoja ole päivitetty rekisterinpitäjälle.

Merkittävä osa rekisteröidyistä veneistä on kalastuksessa ja yhteysveneinä käytettäviä niin sanottuja pulpetti- ja puolikannellisia moottoriveneitä, joihin venevero kohdistuisi sattumanvaraisesti sen 
mukaan, sattuuko koneteho olemaan yli vai alle $38 \mathrm{~kW}$ tai pituus yli vai alle 9 metriä.

Venevero kohdistuisi kansalaisiin sattumanvaraisesti. Yhdenvertaisuutta loukkaavien, perusteiltaan haasteellisten ja kateusveroa muistuttavien verojen sijaan tulisi miettiä, kuinka voidaan edistää työllisyyttä, saaristomatkailua ja suomalaista venealaa ja tätä kautta saada kokonaisuutena suurempi verokertymä. Venevero ei ole linjassa hallituksen norminpurkutalkoiden kanssa, vaan se synnyttää veronmaksajissa epätietoisuutta, katkeruutta ja lisääntyvää kiinnostusta verojen välttämiseen laajemminkin.

\subsection{Klassikkovene- ja höyrypursiseurat}

Klassikkoveneiden asiantuntijaraati vaati, että kulttuurihistoriallisesti arvokkaat huvi- ja kilpaveneet on vapautettava veneverosta. Käytännössä se tarkoittaisi Klassikkorekisteriin hyväksyttyjä veneitä. Menettely olisi samanlainen, joka on jo olemassa museorekisteröidyillä autoilla. Klassikkorekisteri on vuonna 2012 perustettu kansallinen rekisteri, jonka tarkoituksena on kartoittaa ja dokumentoida Suomessa olevat kulttuurihistoriallisesti arvokkaat huvi- ja kilpaveneet. Klassikkorekisteriin hyväksytään vähintään 50 vuotta vanhoja veneitä, jotka on rakennettu Suomessa tai joiden suunnittelija on suomalainen. Rekisteriin on tähän mennessä hyväksytty 181 venettä, ja rekisteriä ylläpitää Mahogany Yachting Society (MYS) Museoviraston ja Forum Marinumin valvomana. Myöhemmin rekisterin on tarkoitus siirtyä Museoviraston hallintaan.

Klassikkorekisterin vanhimmat edelleen purjehtivat veneet ovat yli 100 vuotta vanhoja (rekisterin vanhin vene on rakennettu vuonna 1911, useita veneitä on 1910-, 1920- ja 1930-luvuilta). Veneet edustavat kukin oman aikakautensa huviveneilyn merellistä kulttuurihistoriaa. Niiden kautta on myös mahdollista ymmärtää eri aikakausien rakennus- ja työmenetelmiä. Veron seurauksena myös klassikkoveneitä tultaisiin poistamaan venerekisteristä, kulttuurihistoriallisesti arvokkaiden veneyksilöiden seuranta vaikeutuisi ja huonokuntoisten 
ja harvinaisten veneiden tuhoutumisen tai romuttamisen riski kasvaisi.

Klassikkoveneiden veneilykauden pituus on huomattavan lyhyt. Kevätkunnostukset voidaan tehdä vasta lämpötilan salliessa, ja syksyllä veneet on nostettava kuivumaan hyvissä ajoin ennen pakkasia. Vanhojen puuveneiden kunnostaminen ja ylläpito on taloudellisesti raskasta. Sopivia venehalleja puuveneiden säilytykseen on enää vähän, osaavia puuvenekorjaajia on harvassa ja veneiden kunnostuskustannukset ovat korkeat. Moni veneenomistaja joutuu tekemään valtaosan kunnostustöistä itse.

Lausunnon antoi myös Suomen Höyrypursiseura ry, joka on Euroopan suurimpia perinteisten ja kulttuurihistoriallisesti arvokkaiden höyrylaivojen säilyttämiseen keskittyneitä harrastaja- ja asiantuntijajärjestöjä. Sen tavoitteena on säilyttää höyryaluksiin ja niiden käyttöön liittyvää tietoutta ja perinnettä, järjestää merenkulkutaitoihin ja erityisesti höyrytekniikkaan liittyvää koulutusta sekä varmistaa tiedon siirtyminen nuoremmille höyryharrastajille. Osoituksena turvallisuusosaamisesta osoituksena Tukes ja Trafi ovat myöntäneet Suomen Höyrypursiseuralle höyrylaivojen omakatsastusoikeuden.

Suomessa jäljellä olevat höyrylaivat ovat kulttuurihistoriallisesti arvokkaita perinnealuksia, joiden kulkukelpoisena pitäminen on keskeistä niiden säilyttämiseksi jälkipolville. Alusten ylläpito ja kunnostus on suurelta osin täysin yksityisten omistajien rahoituksen varassa. Järjestely on valtion kannalta kustannustehokas verrattuna maihin, joissa perinnealusten omistus ja säilyttäminen on yleisesti julkisen rahoituksen varassa. Suomalaiset höyrylaivat ovat vuosittain lukuisissa tapahtumissa suuren yleisön tutustuttavissa.

Seuran rekisterissä oli vuoden 2017 alkaessa 90 höyryalusta, joista muutamat ovat ammattiliikenteeseen rekisteröityjä, muutamat eiliikkuvia museoaluksia ja osa vielä kunnostamista odottavia tai muuten poissa aktiivisesta käytöstä. Suunnitellun veneveron tuotto näiden alusten osalta olisi marginaalinen: se koskisi vain hieman yli puolta kaikista höyryaluksista.

Suomen Höyrypursiseura esitti ensisijaisesti kaikkien perinnehöyrylaivojen vapauttamista veneverosta ja toissijaisesti vapautusta niille Trafin venerekisteriin merkityille höyrylaivoille, jotka ovat samanaikaisesti hyväksyttyjä Museoviraston perinnelaivarekisteriin. 


\subsection{Partiolaiset}

Suomen Partiolaiset totesi, että venevero koskettaisi myös suomalaisten lasten ja nuorten harrastamista. Se katsoi lakiesitystä ainoastaan lasten ja nuorten veneilyharrastustoiminnan kannalta. Suomen Partiolaiset on Suomen suurin nuorten vapaaehtoisjärjestö; sillä on 65000 jäsentä. Partiotoimintaa harjoitetaan 750 lippukunnassa kautta maan. Meripartiotoiminta on monipuolista ja haastavaa toimintaa tytöille ja pojille; sen koulutusohjelma käytännön harjoitteluineen tarjoaa meripartiolaisille ainutlaatuisen ympäristön harrastaa ja oppia yhdessä uusia taitoja ja asioita. Meripartiolaisia on noin 6500 , ja he toimivat noin 70 lippukunnassa sekä merellä että järvillä.

Venevero koskettaisi yli 50:tä partioalusta, joilla koulutetaan lapsista ja nuorista vastuullisia veneilijöitä yhteiskuntaamme. Suomen Partiolaiset ilmaisi huolensa siitä, millaisia vaikutuksia kaavaillulla verolla olisi tärkeään lasten ja nuorten meripartiotoimintaan. Veneverolaissa tulisi ottaa paremmin huomioon lasten ja nuorten parissa tehtävä meripelastus- ja koulutustoiminta. On ongelmallista, että verotus koskettaisi vain yhtä harrastusmuotoa ja näin asettaisi lapset ja nuoret epätasa-arvoiseen asemaan. Veneverolaki ei saisi asettaa nuorten meripelastus- ja koulutustoimintaan lisää kulueriä.

Veneverotukseen liittyvä ongelma poistettaisiin esimerkiksi lisäämällä kaavailtuun veneverolakiin säännös, jolla poistettaisiin verovelvollisuus vesikulkuneuvon omistajana/haltijana toimivilta yhdistyksiltä, jotka järjestävät pääasiallisesti koulutusta tai meripelastustoimintaa alle 29-vuotiaille lapsille ja nuorille. Lakia laadittaessa määriteltäisiin ne keskusjärjestötahot, joiden paikallisyhdistykset saisivat verohelpotuksen.

\subsection{Sukeltajat}

Sukeltajaliitto totesi olevansa 60 vuotta toiminut sukelluksen valtakunnallinen lajiliitto. Eri puolilla Suomea sijaitsevat 161 sukellusseuraa ovat sen jäseniä, ja jäsenyyden piirissä on lähes 10000 harrastajaa. Sukeltajaliitto vastaa myös Vapaaehtoisen pelastuspalvelun Vapepa- 
sukeltajien kouluttamisesta. Vapepa-sukeltajat toimivat viranomaisten apuna ei-kiireellisissä etsintätehtävissä.

Liitto painotti yleishyödyllisten yhdistysten näkökulmaa. Vapaaehtoisuuteen perustuvassa kansalaistoiminnassa eri yhdistyksissä opitaan tärkeitä kansalaistaitoja, ja yhdistyksissä tehtävä vapaaehtoistyö on myös yhteiskunnallisesti merkittävää. Muun muassa sukellusseurat ja vapaaehtoiset meripelastusseurat tekevät viranomaisyhteistyötä ja täydentävät viranomaisresursseja. Esimerkiksi vedenalaisiin etsintöihin ei viranomaisilla maanlaajuisesti aina ole tarvittavia resursseja tai osaamista. Suomessa toimii lukuisia sellaisia yleishyödyllisiä yhdistyksiä, joissa veneiden käyttö on oleellinen osa toimintaa - esimerkkeinä sukellusseurat, meripartiolaiset, meripelastusseurat sekä purjehdus- ja veneilyseurat. Yhdistystoiminnassa koulutus on tärkeä toiminnan osa-alue. Seurat toimivat usein pienin resurssein, mutta ne ovat merkittäviä veneilyn turvallisuutta ja veneilytaitoja lisäviviä toimijoita; niiden toimintaedellytyksiä ei tulisi heikentää uusilla veroilla. Sukellusseuroilta tulee jatkuvasti viestejä heikentyneestä taloudellisesta tilanteesta. Moni kunta on korottanut esimerkiksi uimahallien käyttövuoromaksuja, mikä rasittaa seurojen taloutta. Venevero toteutuessaan olisi jälleen yksi sellainen kuluerä, joka heikentäisi yleishyödyllisten yhdistysten toimintaedellytyksiä. Yleishyödyllisten yhdistysten omistamat veneet olisi jätettävä veneveron ulkopuolelle.

\subsection{Kalastajat ja kalastusoppaat}

Suomen Vapaa-ajankalastajien Keskusjärjestö esitti veneverosta luopumista. Vero kohdistuisi suurelta osin kalastuksen harrastajiin; se vaikeuttaisi etenkin uistelijoiden ja heittokalastajien harrastusta merellä ja suurien järvenselkien alueilla. Vapaa-ajankalastus on suomalaisten luontoliikuntamuodoista merkityksellisimpiä. Maassamme oli vuonna 2014 hieman alle 1,6 miljoonaa vapaa-ajankalastajaa, eli suomalaisista lähes joka kolmas harrastaa kalastusta. Harrastuksen tuottaman 29 miljoonan kalakilon ohella saadaan merkittäviä määriä aineettomia hyötyjä, kuten positiivisia terveysvaikutuksia. Merkittävä osa vapaa-ajankalastuksen saaliista pyydetāän käyttämällä apuna moottorilla varustettua venettä. 
Veneiden turvallisuus on kehittynyt viimeisen vuosikymmenen aikana. Aaltoa paremmin halkaisevat V-pohjat tuovat veneisiin vakautta aallokkoisessa kelissä. Nykyiset veneet vaativat suuren konetehon: jopa vain viiden metrin mittaisissa avoveneissä käytetään yli 38 $\mathrm{kW}: \mathrm{n}$ tehoisia moottoreita. Vero johtaisi vapaatehoisten moottoreiden suosimiseen ja veneiden pienenemiseen, mikä lisäisi turvattomuutta vesillä.

Veroa ollaan asettamassa 12 kuukauden aikajaksolle. Tämä tuo eriarvoisuutta kansalaisten asuinpaikan mukaan. Saaristomerellä veneilykausi voi olla jopa 10 kuukautta vuodessa, mutta Lapissa se voi jäädä jopa vain neljään kuukauteen. Vero ei erittele veneen arvoa, joten vero nousee kohtuuttoman suureksi vanhempien veneiden osalta.

Verokertymä oli esityksessä arvioitu yläkanttiin. Venerekisteri on puutteellinen ja sisältää suuren määrän haamuveneitä, joista ei tulla maksamaan veroa vaan jotka ilmoitetaan käytöstä poistetuiksi. Tämä tulee pienentämään kertymää. Lisäksi veron vaikutukset venekauppaan ja kalastustarvikekaupan osalta erityisesti vetouistelutarvikekauppaan tulevat olemaan negatiivisia ja näin pienentämään verokertymää.

Suomen Kalastusopaskilta ry esitti, että ammattikäytössä olevien vuokravenekatsastettujen opasveneiden tulisi olla vapaita veneverosta. Alusrekisterissä olevat ammattimaisen liikenteen alukset ovat jo esitysluonnoksen mukaan verovapaita. Ammattimaista vesiliikennettä harjoitetaan myös sellaisilla aluksilla (veneillä), joita ei voida kokonsa puolesta rekisteröidä alusrekisteriin. Ammatinharjoittajien, yritysten ja kaupallisten kalastajien tasapuolisuuden turvaamiseksi olisi verottomuus taattava myös näille pienemmillä veneillä ammattitoimintaa harjoittaville. Kalastusoppaan liiketoiminnassaan käyttämän aluksen pitäisi olla verovapaa, kuten ovat ammattikalastajan kalastusalusrekisterissä olevat alukset, jos seuraavat ehdot täyttyvät:

1. Veneen omistaja on yritys (voimassa oleva Y-tunnus).

2. Vene on katsastettu vuokraveneeksi.

3. Veneelle on asetettu miehitystodistus.

4. Yrittäjällä on ammattimaisessa liikenteessä vaadittava kuljettajakirja. 
5. Alus on merkitty kalastusalusrekisteriin. Kaupallisen kalastajan alle 10-metrisen veneen saa kalastusalusrekisteriin, mutta sitä eivät koske alusrekisterin katsastus- ja varuste- tai pätevyysvaatimukset, kuten vuokraveneitä. Näin ollen kalastusoppaat ovat veneveron, veneen varustelun ja opastoiminnan suhteen eri asemassa kuin ammattikalastajat. Ammattikalastajia kehotetaan ja koulutetaan yhä enenevässä määrin harjoittamaan kalastusopastoimintaa rekisteri- ja verovapaalla kalustollaan. Opasalusten merkintä kalastusalusrekisteriin on tehtävä mahdolliseksi.

6. ELY-keskus on myöntänyt oppaalle kalastuslain $18 \$$ :n mukaisen alueellisen luvan kalastusopastoimintaan.

Kaavailtu venevero saattaisi houkutella käyttämään henkilökuljetuksiin riittämättömän kokoista kalustoa $(50$ hv:n tai pienempi moottori). Raskaat kuormat, pienehkö vene ja alitehoinen moottori heikentävät turvallisuutta. Jos henkilökuljetuksiin käytetyt veneet ja moottorit ovat vapaita veneverosta, se kannustaa käyttämään suurempia ja turvallisempia yhdistelmiä.

Kalastusmatkailua ja venevuokrausta harjoittava yritys Fishinno Finland totesi, että ministeriön esityksessä oli huomioitu alusrekisteriin ja kalastusalusrekisteriin kuuluvien alusten vapautus verosta. Ammattikäytössä on kuitenkin myös muita veneitä, joita ei kokonsa tai toiminnan luonteen vuoksi voida rekisteröidä kyseisiin rekistereihin. Esimerkiksi kalastusmatkailu- ja venevuokraustoiminnan piirissä olevista veneistä on Trafin ylläpitämä vuokravenerekisteri. Tasapuolisuuden nimissä tulisi myös nämä muut ammattikäytössä olevat veneet vapauttaa verosta. On kohtuutonta, että työkäytössä olevista veneistä pitäisi maksaa vuotuista käyttöveroa. Minkään muun ammattiryhmän työkaluja ei veroteta samantyylisellä pisteverolla. Esimerkiksi sorvarin ei tarvitse maksaa sorvista käyttöveroa eikä metsurin sahastaan moottorisahaveroa. Venevero kohtuuttomasti ja epäoikeudenmukaisesti rankaisisi liiketoiminnassaan venettä/veneitä käyttäviä yrityksiä.

Fishinnolla on ammattimaisessa kalastusmatkailu- ja järviretkeily liiketoiminnassa kolme kaavaillun veron piiriin kuuluvaa pienvenettä. Tälle pienyritykselle lankeaisi kohtuuton 760 euron vuotuinen vero liiketoiminnassa käytettävistä työkaluista. Kalastusoppaan tai 
venevuokrausta harjoittavan yrityksen vuokraveneeksi katsastetun ja yksinomaan liiketoiminnassa käytettävän veneen pitäisi olisi yhtäläisesti verovapaa kuin kalastusalus tai alusrekisterissä olevat alukset. Seuraavia kriteereitä olisi mahdoton kiertää, mikäli joku haluaisi tässä keinotella, sillä esimerkiksi arvonlisäverolaki määrittelee tiukasti huvitai urheilukäyttöön valmistetun veneen arvonlisäverokelpoisuuden. Verovapauden kriteereinä voisivat olla esimerkiksi seuraavat:

- veneen omistaja/haltija on yritys (voimassa oleva Y-tunnus),

- veneellä on Trafin vuokravenekatsastus, ja vene on merkitty Trafin vuokravenerekisteriin,

- vene on täysin arvonlisäverovelvollisessa yritystoiminnassa.

\subsection{Saariston siisteyden edistäjät}

Pidä Saaristo Siistinä ry on valtakunnallinen, vuonna 1969 perustettu veneilijöiden ja vesillä liikkujien ympäristöjärjestö. Se edistää Suomen merialueiden, sisävesien, rantojen ja saariston puhtautta, viihtyisyyttä ja turvallisuutta sekä veneily- ja retkeilymahdollisuuksia. Näiden päämäärien eteen tehdään konkreettista jätehuoltotyötä ja ympäristökasvatustyötä sekä toteutetaan erilaisia projekteja. Yhdistyksen toiminnalla ehkäistään vähäisin kustannuksin ympäristön roskaamista ja vesistöjen rehevöitymistä sekä ylläpidetään vesillä liikkujille laajaa retkisatamaverkostoa jätehuolto- ja käymäläpalveluineen. Järjestö osallistuu aktiivisesti Itämeren suojeluun ja kehittää uusia keinoja veneilyn ympäristövaikutusten pienentämiseksi. Tämän toiminnan rahoittamisessa ovat veneilijöiden maksamista vapaaehtoisista jäsenmaksuista kertyvät tuotot ensiarvoisen tärkeitä. Yhdistys ylläpitää ja tuottaa yhteistyössä useiden tahojen kanssa kokonaistaloudellisesti erittäin edullisesti laajoja palveluja vesillä eri tavoin liikkuville. Palvelut mahdollistavat luonnossa virkistäytymisen ja liikkumisen ympäristöä rasittamatta.

Yhdistys totesi uhaksi sen, että veneveron vuoksi merkittävä osa veneilijöistä tasapainottaisi veneilystä aiheutuvia kustannuksia luopumalla muun muassa Pidä Saaristo Siistinä ry:n jäsenmaksun kaltaisista vapaaehtoisista maksuista. Tätä kautta veron negatiiviset vaikutukset 
ympäristöön voivat olla yllättävän suuret. Esityksessä arvioitu veneverokertymä olisi 0,3 promillen luokkaa valtion budjetista. Kertymän merkitys valtion talouteen olisi vähäinen, mutta toteutuessaan vero olisi negatiiviselta vaikutukseltaan sitäkin suurempi suhteessa veneilijöiden käyttämien palvelujen laajuuteen, veneilykoulutukseen, vapaaehtoiseen meripelastustoimintaan ja myös kyseisenlaisiin yleishyödyllisiin yhteisöihin, joiden toiminta tukeutuu pitkälti veneilijöiden vapaaehtoisesti maksamiin maksuihin.

Vesikulkuneuvoihin kohdistuvat jo nyt polttoainevero ja arvonlisävero. Arvonlisäveroa kertyy lisäksi veneilijöiden hyödyntämien palvelujen kautta. Venerekisteriä ei ole suunniteltu käytettäväksi verotustarkoituksiin, eikä uuttakaan rekisterilainsäädäntöä kehitettäessä sellaiseen ole varauduttu. Esimerkiksi Ruotsissa veneverosta luovuttiin kokeilun jälkeen, koska veron tuotto jäi varsin pieneksi. Venerekisterin puutteellisuuksista johtuen veron keräämiseen liittyvät hallinnolliset kustannukset Suomessakin nousisivat saatavaan tuottoon nähden suhteettoman suuriksi.

Verojärjestelmän ensisijainen tehtävä on rahoittaa julkisia palveluja ja tulonsiirtoja. Kotitaloudet tekevät jatkuvasti erilaisia pitkävaikutteisia taloudellisia valintoja. Siksi veropolitiikan tulisi olla myös johdonmukaista ja ennustettavaa, ei veneveron kaltaiseen pisteveroon tukeutuvaa. Veron tulisi myös olla yksinkertainen ja helposti kerättävissä.

Esitys ei täytä hyvän veropolitiikan periaatteita, eikä se myöskään tue ympäristön kannalta myönteisiä toimia.

\subsection{Sähköajoneuvojen puolestapuhujat}

Sähköautoilijat ry totesi, että vaikka verolaki on luonteeltaan valtiontaloudellinen, lain rajauksella voitaisiin ohjata veneilyä ympäristöystävällisempään suuntaan. Tämä tapahtuisi siten, että veroa ei veneestä kannettaisi, jos moottorin käyttövoima olisi sähkö. Suomessa ei ole vielä yhtäkään yli 38 kilowatin moottorilla varustettua sähköllä toimivaa venettä, mutta Euroopan ja USA:n markkinoilla sellaisia jo on. 
Lisäksi on meillä ainakin yksi ja Ruotsissa toinen hyvinkin pitkällä oleva kaupallinen sähkövenehanke, jonka tuotteet valmistuessaan olisivat ehdotetun lain piirissä. Kevyiden moottoriajoneuvojen veroehdotuksessa rajattiin veron ulkopuolelle sellaiset kevyet moottoriajoneuvot, joiden käyttövoima on sähkö. Tämä on erittäin hyvä ja ohjaava elementti ympäristön ja tulevaisuuden kannalta. Suomessa on nykyisin rekisterissä noin 35 sellaista L3- ja L3e-luokan ajoneuvoa, joiden käyttövoima on sähkö.

Sähkömoottoreihin otti kantaa myös J. Rintamäki. Hän totesi, että veneverotuksesta tulisi ensisijaisesti luopua sen tasapuolisen soveltamisen mahdottomuuden ja vähäisen verokertymän vuoksi. Mikäli veneiden verottamiseen päädyttäisiin, olisi moottoritehoon perustuva veron porrastus luonteva ja oikeansuuntainen. Veneiden verotuksessa tulisi soveltaa samaa ohjausvaikutusta kuin tieliikenteessä ja sitoa vero ainoastaan päs̈stöihin, vaihtoehtoisesti moottorin tehoon. Veneen pituuteen sidottu vero ainoastaan mitätöi ohjausvaikutukset, jotka ohjaavat veneilyä ympäristöystävälliseen purjeveneilyyn. Lakiesitys on puutteellinen myös perusteiltaan, koska veroperusteena on käytetty pelkästään moottoritehoa. Sähkömoottorit ovat lyömässä itseään läpi myös veneilyssä, ja tällaisenaan venevero ei kannusta ympäristölle edullisen tekniikan yleistymistä.

\subsection{Auto- ja liikennetoimittajat}

Auto- ja liikennetoimittajat ry AuLi oli huolissaan veron vaikutuksista muun muassa ympäristöohjaavuuden, venealan suoran ja välillisen työllisyyden sekä valtion verotulojen kasvun kannalta. Pistemäinen omistuspohjainen venevero merkitsisi paluuta menneisyyden vanhentuneisiin huvi- ja ylellisyysveroihin. Veneen käyttö on pääasiassa virkistysharrastus ja kausiluonteinen liikennemuoto. Harrastuksen omistusverottaminen ei täytä hyvän verojärjestelmän ominaisuuksia sen paremmin fiskaalisten tavoitteiden, tasapuolisuuden, oikeudenmukaisuuden kuin hallinnollisen tehokkuudenkaan osalta.

Veroon liittyisi useita oikeudenmukaisuusongelmia. Venevero on todennäköisesti perustuslain vastainen koskiessaan käytännössä vain 
osaa Suomea. Yksittäisenä esimerkkinä veron ongelmista yhdistys mainitsee, että kilpakäyttöön tarkoitetut veneet lakiluonnoksen mukaan välttyisivät verolta, sillä niitä ei tarvitse rekisteröidä. Onko lainsäätäjä tietoinen siitä, että myös perhepurjeveneillä kilpaillaan? Miksi esimerkiksi kilpakalastaminen on lainsäätäjän mielestä vero-ohjausta kaipaava harrastemuoto, mutta rekisteröity nopeuskilpailukäyttö ei?

Omistuspohjainen venevero sopisi huonosti nykyiseen verojärjestelmään, jossa progressiivinen ansiotuloverotus, kulutuksen arvonlisäverotus ja käytön verotus muodostavat toimivan kokonaisuuden. Veroa ei voida myöskään perustaa nykyiseen venerekisteriin, koska sen tiedot eivät ole tarpeeksi kattavat ja luotettavat.

Veneveron ympäristöohjaavuus olisi surkealla tasolla. Vero ei huomioi nykyaikaista moottoritekniikkaa eikä veneiden todellisia käyttöpäiviä, vaan verotus perustuisi omistamiseen. Jos lainsäätäjä on halunnut vain ylellisyysverottaa veneharrastusta, on sekin lähtökohta yksityiskohdiltaan ja päästöohjaavuuteen suhteutettuna erittäin outo. Esimerkiksi miljoonan euron purjeveneen omistaja maksaisi selvästi vähemmän vuotuista veneveroa kuin muutaman tonnin arvoisen perusmoottoriveneen omistaja. Veneveron kaltaisia veroja on käytössä vain kolmessa maassa. Kansainväliset kokemukset veneveroista ovat huonoja, eivätkä ne tue veron toteuttamista Suomessa.

Esitys ei täytä hyvän ja huolellisen lainvalmistelun periaatteita. Esitys on valmisteltu poliittisessa paineessa ja kiireessä, ja veneveron tuotto jäisi selvästi alle esitettyjen laskelmien. Verolla olisi haitallinen vaikutus veneilyyn, veneiden kotimaiseen valmistukseen ja kauppaan sekä kaikkeen muuhunkin veneilyyn ja satamien kesään liittyvään liiketoimintaan, mikä osaltaan leikkaisi valtion verotuottoja.

Yhdistys oli huolissaan myös alan toimittajien sekä vene- ja vesiliikenneaiheista mediasisältöä tuottavien medioiden puolesta. Veron aiheuttama toimialan ja sitä kautta veneilevän yleisön supistuminen koskisi välillisesti myös aiheesta kirjoittavia medioita sekä näille sisältöä tekeviä erikoistoimittajia ja muuta journalistista henkilöstöä. 


\subsection{Veroprofessori}

Ministeriö ei pyytänyt lausuntoa yhdeltäkään vero-oikeuden professorilta, mutta finanssioikeuden emeritusprofessori Esko Linnakangas lähetti kannanottonsa sekä veneverosta että moottoripyörien ajoneuvoverosta, koska teema kiinnosti häntä tutkijana. Hän totesi, että verotulojen lisääminen on hyväksyttävä tavoite varsinkin alijäämäisten budjettien aikana. Esityksiä valmisteltaessa oli kuitenkin selvinnyt, että kyseisillä veroilla ei voida saavuttaa tuota tavoitetta. Verotuotto jäisi hallitusohjelmassa mainittua selvästi alemmaksi. Esitetyt verot myös heikentäisivät yritystoimintaa ja työllisyyttä ja olisivat siten ristiriidassa jopa hallitusohjelman tavoitteiden kanssa.

Entisaikojen ylellisyysverojen sukulaisina kyseiset verot eivät nyt ole oikea ja tehokas keino valtion verotulojen lisäämiseksi. Verotulojen lisäämistavoite saavutetaan paljon paremmin ja veronmaksukykyisyyttä kunnioittaen esimerkiksi valtion tuloverotusta ylemmissä tuloluokissa minimaalisesti tiukentamalla. Varallisuusveroa ei ole mieltä synnyttää uudelleen ainoastaan veneiden ja moottoripyörien verolle panemiseksi.

Esitetyt verot eivät olisi myöskään oikeasuhtaisia, koska ne olisivat käyttöpäiviä kohden laskettuna moninkertaisia verrattuna autojen ajoneuvoveroon. Esitykset herättävätkin epäilyjä perustuslaissa turvatun yhdenvertaisuusperiaatteen loukkaamisesta. Voidaan myös kysyä, onko ajoneuvojen luokittelussa verollisiin ja verottomiin mielivaltaisuutta.

Vakava puute lainvalmistelussa on nyt se, että esityksiin ei sisälly oikeusvertailua veneiden eikä moottoripyörien ajoneuvoverotuksesta. Ehdotuksessa ei kerrota edes sitä, onko esimerkiksi Virossa ja muissa naapurimaissamme vastaavia veroja. Mikäli maakohtaiset erot ovat suuria, voi syntyä myös EU-oikeudellisia ongelmia.

Veneverohankkeesta olisi luovuttava. Jos luopumista ei hallitusohjelman vuoksi pidetä mahdollisena, esityksiin olisi lisättävä ainakin oikeusvertaileva osa sekä analyysi perustuslakimme ja EU-oikeuden vaatimuksista. Mikäli esitykset eduskunnalle annetaan, olisi harkittava perustuslakivaliokunnan lausunnon pyytämistä.

Tasapuolisuuden vuoksi veromääriä olisi alennettava olennaisesti, vaikkapa kolmannekseen nykyehdotuksista. Mutta silloin esityksillä 
ei olisi mitään valtiontaloudellista merkitystä ja eduskunnan tulisi jo sillä perusteella hylätä esitykset.

Jos taas tavoitteena on haittavero, siis jos halutaan myös vähentää ajoneuvojen hankintaa ja käyttöä ympäristö- ja terveyshaittojen vuoksi, perustelut olisi kirjoitettava aivan uusiksi. Veromääriä pitäisi silloin vaikuttavuuden lisäämiseksi myös selvästi nostaa ja verollisten ajoneuvojen piiriä laajentaa. Tällainenkin vero voisi synnyttāä perustuslaillisia kysymyksiä siitä huolimatta, että perustuslakivaliokunnan linjaukset vuoden 2016 lopulla (eläketulon lisävero, metsälahjavähennys) antavat hallitukselle ja eduskunnalle varsin suuren vapauden veropolitiikkansa harjoittamiseen.

\subsection{Yksittäiset kansalaiset}

Edellä mainittujen tahojen lisäksi lausuntonsa antoi hyvin moni yksityishenkilö. Seuraavassa selvitetään näistä lausunnoista muutamia. Esille otetaan lähinnä näkökohtia ja ehdotuksia, joita ei ole jo laajasti käsitelty edellä selostetuissa lausunnoissa.

H. Timgren totesi, että jotkut harrastavat veneillään kalastusta, jotkut matkaveneilyä kesäloman ajan, jotkut haluavat vain olla vesillä; jotkut harrastavat kilpapurjehdusta ja joillekin uistelukilpailut ovat tosi tärkeitä. Monet käyttävät kilpapursiaan myös perhepurjehdukseen. Nämä veneet on varusteltu täyttämään ennen kaikkea kilpapurjehduksen vaatimukset. Miksi nämä veneet pannaan verolle samalla kun "kilpaveneet" jäävät verotuksen ulkopuolelle? Ehdotuksessa puhutaan pelkästään kilpailukäytössä olevista veneistä, jotka siis jäävät veron ulkopuolelle. Tarkoittaako tämä sitä, että kun yli yhdeksänmetrinen vene viedään purjehtimalla Helsingistä Sandhamniin Gotland Runt -kisan lähtölinjalle, veneessä ei saa olla muita kuin kilpailumiehistö? Miksi "kilpaveneitä" halutaan suosia ja kilpailuissa käytettäviä myös perheveneilyyn sopivia pursia halutaan syrjiä? Uistelukilpailuharrastus on suosittua. Siihen käytettävät veneet on varusteltu pelkästään uistelua varten, ja niitä vedetään trailereilla ympäri Suomea kilpailusta toiseen. Esityksessä mainitaan, että verovapaus ei koske kalastuskilpailuveneitä. Miksi valtiovalta katsoo uistelukilpailuharrastuksen jotenkin huonommaksi ja haluaa syrjiä sitä? 
V. Stenvallin mielestä veron määrä kohdistuu epäoikeudenmukaisesti liukuvarunkoisiin veneisiin. Liukuvarunkoinen vene tarvitsee kohtuullisen ison moottoritehon toimiakseen teknisesti siten kuin on suunniteltu. Muita venetyyppejä ovat uppoamarunkoinen, puoliliukuva, moottoripurjevene ja purjevene. Nämä venetyypit eivät ole niin riippuvaisia moottoritehosta. Veron määräytymisperuste olisi muutettava venetyyppien välillä oikeudenmukaiseksi ja tasavertaiseksi vastaamaan vesikulkuneuvojen todellista arvoa. Määräytymisperusteessa olisi myös otettava huomioon vesikulkuneuvon käyttöönottovuosi, joka on yksi venerekisterissä käytettävissä olevista tiedoista. Määräytymisperuste voisi rekisteröidyille veneille muodostua seuraavasti:

\begin{tabular}{|c|c|}
\hline ennen vuotta 1980 & 0,3 \\
\hline 1980-1990 & 0,5 \\
\hline 1990-2000 & 0,7 \\
\hline 2000-2010 & 0,9 \\
\hline 2010-2016 & 1,0 \\
\hline
\end{tabular}

J. Hopponen totesi, että venevero on perustuslaillisesti kyseenalainen, koska kyseessä on yhdenlajisen irtaimen omaisuuden verottaminen. Samaan aikaan yhtä "turhia" pienempiä veneitä, kilpaveneitä tai alle yhdeksänmetrisiä pienmoottorisia veneitä ei veroteta. Myöskään ei lisäveroteta ravihevosia tai edes niiden kuljetuskärryjä. Hiljaa pyöritettäviä uppoumaveneitä verotetaan kuten harvinaisia todellisia muskeliveneitä. Veneisiin on saatettu alun perin turvallisuussyistäkin asentaa veneen runkonopeuden tarpeen ylittävä moottori. Käyttöteho jää murto-osaan siksi, että venettä ylipäänsä ei juuri kukaan käytä myrskyssä, vaikka sen varalta vene pitää suunnitella, jotta se olisi aina turvallinen. Veneveroa parempi vaihtoehto olisi esimerkiksi kaikille tasapuolinen polttoaineveron nosto, joka toteutuisi ilman perintäkuluja ja "aiheuttaja maksaa" -periaatteen mukaisesti. Hopponen aikoo veneveron mahdollisesti tullessa luopua veneestä ja ryhtyä har- 
rastamaan ulkomaanmatkailua; hän ei hyväksy yhteen harrasteeseen kohdistuvaa rankaisevaa omaisuusveroa, joka lisäksi on fiskaaliselta kannalta ja perimiskustannuksiltaan aivan absurdi ja jolle olisi ilmainen vaihtoehto. Veneilyä ei tarvitse kokonaan lopettaa, koska sitä voi jatkossa harrastaa vuokraveneillä esimerkiksi Britanniassa, Kroatiassa, Virossa, Kreikassa ja muualla Euroopassa.

K. Kakko esitti veron porrastamista veneen iän mukaan siten, että yli 50 vuotta vanha vene olisi kokonaan verosta vapaa. Tämä tarkoittaa kahden prosenttiyksikön veronalennusta kutakin ikävuotta kohden. Tulisi asettaa myös tehohaarukka kaikkien markkinoilla olevien huviveneiden tehoja vastaavaksi. Oikeustajua koettelee, jos tavallisen perheveneen vero on samansuuruinen kuin tuhannella hevosvoimalla varustetun miljoonaveneen. Samoin asetettaisiin vero veneen käyttöpäivien mukaan, niin kuin autojen ajoneuvovero. Tulisi harkita sitäkin vaihtoehtoa, että verotuksen piiriin tulisivat ainoastaan sertifioidut, esimerkiksi CE-kilvellä varustetut veneet. Niistä on kattavat tietokannat, jolloin poistuisi kaikki epävarmuus teknisistä tiedoista eikä verotuksen tarvitsisi olla veneen omistajan ilmoittamien tietojen tai luulojen varassa. Mikäli nämä tasa-arvoa tukevat muutokset johtavat verotuspohjan kapenemiseen kannattamattomaksi, ei Suomen kaltaisessa sivistysvaltiossa ole syytä tämän veron valmistelua jatkaa.

$M$. Suominen puolestaan sanoi ymmärtävänsä ylellisyyshyödykkeiden verotuksen, mutta esitetty venevero ei kohtelisi kansalaisia yhdenvertaisesti. Perussuomalaisten puheenjohtaja Timo Soini on perustellut veneveroa viittaamalla "huvikuunareihin". Viiden miljoonan euron vene kyllä onkin huvikuunari, mutta saman veron maksavaa 4000 euron paattia ei voi sellaiseksi kutsua. Lisäksi edullisista veneistä, joissa on isohko moottori, tulisi veron myötä käytännössä arvottomia. Jos veneilyä haluttaisiin verottaa, oikeudenmukaisempaa olisi verottaa uusia veneitä. Tällöin vero pohjautuisi oikeudenmukaisesti veneen oikeaan arvoon ja kohtelisi kansalaisia tasapuolisesti. Se tosin vähentäisi uusien veneiden kauppaa ja nostaisi käytettyjen veneiden arvoa. 


\section{4 \\ Tiivistelmä veneveron haitoista ja eduista}

\subsection{Kielteistä}

Valtiovarainministeriössä valmistuneesta veneveroesitysluonnoksesta annetuissa lausunnoissa esitystä kritisoitiin seuraavanlaisilla perusteilla:

1. Veneveroa kertyisi paljon vähemmän kuin tavoitellaan.

2. Kun muiden verojen pieneneminen otetaan huomioon, valtion verotuotto olisi negatiivinen.

3. Veneiden määrä vähentyisi.

4. Venevero loukkaisi perustuslaissa turvattua yhdenvertaisuutta.

5. Venevero olisi sattumanvarainen verokohteissa ja -määrissä.

6. Veneveron pohjana oleva venerekisteri on epäluotettava.

7. Veneteollisuuden ja venealan tavara- ja palvelukaupan työllisyys heikentyisi.

8. Kotimaan matkailu ja matkailualan työllisyys heikentyisi.

9. Ulkomaanmatkailu ja ulkomailla veneily sekä muu kuluttaminen lisääntyisivät.

10. Veneomistus on huono maksukyvyn mittari. 
4 Tiivistelmä veneveron haitoista ja eduista

11. Veron määrä olisi liiallinen veneilykauden lyhyyteen nähden.

12. Veromäärä olisi riippumaton ajomäärästä.

13. Se, että veneiden ikää ei otettaisi huomioon, johtaisi vanhojen veneiden liikaverotukseen uusiin veneisiin verrattuna.

14. Veneveron määrä olisi liiallinen autojen ajoneuvoveroon verrattuna.

15. Venevero olisi kohtuuton rasite veneiden myyjille ja vuokraajille.

16. Venevero olisi kohtuuton veneitä ammatissaan käyttäville.

17. Venevero vaarantaisi vapaa-ajan kalastusta.

18. Venevero vaarantaisi meripelastustoimintaa.

19. Venevero vahingoittaisi vesiurheilutoimintaa.

20. Venevero vaikeuttaisi kulttuurihistoriallista venetoimintaa.

21. Venevero vaikeuttaisi nuorisotoimintaa.

22. Venevero vaikeuttaisi yleishyödyllistä toimintaa.

23. Venevero vaikeuttaisi perheenjäsenten yhteistä harrastustoimintaa.

24. Venevero vaarantaisi turvallisuutta vesillä alitehoisten moottorien takia.

25. Venevero vaikeuttaisi ympäristönsuojelua.

26. Veneveron seurauksena sähköveneiden asema vaikeutuisi.

27. Veneveron heikentäisi saariston siisteyttä.

28. Venevero vaikeuttaisi rannikkoseudun ruotsinkielistä ja muutakin toimintaa.

29. Venevero aiheuttaisi verotuksessa menettelyeroja Manner-Suomen ja Ahvenanmaan välillä.

30. Venevero lisäisi byrokratiaa.

31. Veneverotus lisäisi viranomaisten hallintokustannuksia.

32. Veneverotus lisäisi verovelvollisten hallintokustannuksia.

33. Venevero lisäisi verosuunnittelua ja verovilppiä.

34. Veneveron valvonta olisi vaikeaa.

35. Venevero vaarantaisi oikeusturvaa. 
36. Veneverosta on ulkomailla kielteisiä kokemuksia.

37. Verovero olisi nykyaikaan soveltumaton ylellisyysvero.

Lisäksi useissa kannanotoissa (mm. oikeusministeriön lausunnossa) esitettiin kritiikkiä ehdotuksen yksityiskohdista ja tehtiin niihin muun muassa lakiteknisiä parannusehdotuksia.

Venevero näyttäisi vaikuttavan kielteisesti lähes kaikkeen. Taitaa olla vain yksi tärkeä näkökulma, josta veroa ei ole vielä tuomittu: sukupuolisyrjintä. Ministeriön esitysluonnoksessa ja siitä annetussa lausunnossa veneveroa ei tarkasteltu seksuaalisen tasa-arvon kannalta. Jos miesseuraa etsiville naisille joskus annettu vinkki mennä rannikkolaivurikurssille perustuu faktoihin, venevero tuskin olisi täysin sukupuolineutraali. Moottoripyörien ajoneuvoveroa koskevassa esityksessä veron mainittiin kohdistuvan 90-prosenttisesti miehiin, mutta se esitys kaadettiin muilla perusteilla.

\subsection{Myönteistä}

Valtiovarainministeriölle annetuista netissä julkaistuista noin 50 lausunnosta vain yksi on luokiteltavissa myönteiseksi. Se on liikenneja viestintäministeriön lausunto, jossa esityksen tavoitteita pidettiin perusteltuina ja puollettiin ajoneuvorekisterin kanssa mahdollisimman yhdenmukaista lainsäädäntöteknistä ratkaisua.

Useat lausunnon antajat pitivät verotulojen lisäämistä ymmärrettävänä tavoitteena mutta totesivat, ettei esitetty venevero sovellu siihen. Näitä lausuntoja ei voi luokitella esitykselle myönteisiksi. Veneverolle myönteisenä ei voi pitää myöskään lausuntoa, jossa kannatettiin painopisteen siirtämistä työn verotuksesta kulutusverotukseen mutta vastustettiin veneveroa.

Vaikka ministeriölle annetuista lausunnoista siis vain yhdessä suhtauduttiin veneveroesitykseen myönteisesti, se ei tarkoita, että lausunnon antaja olisi maan ainoa veneveron kannattaja. Veneveroa puolustavien argumentti mielipidesivuilla ja yksityisissä keskusteluissa on yleensä tämä: "Valtio tarvitsee varoja tehtäviensä hoitamiseen, ja se, jolla on varaa hankkia ja pitää vene, pystyy myös maksamaan siitä veroa; verotetaanhan autoistakin." 


\section{5 \\ Veneveron hautaamisesta, elvytyksestä ja korvikkeista}

\subsection{Esityksen torpedoiminen ja verotarve}

Valtiovarainministeriön esitys veneverosta (kuten myös esitys moottoripyörien ajoneuvoverosta) sai annetuissa lausunnoissa ja julkisuudessa murskaavan tuomion. Esitystä arvosteltiin myös hallituspuolueissa. Pisimpään veroa kannatti perussuomalaisten puheenjohtaja, mutta lopulta hänkin antoi periksi. Hallitus päätti 15.2.2017 luopua verohankkeesta, koska hyötysuhde oli heikko eikä löytynyt toimivaa ja tuottavaa mallia.

Luopuminen oli ainoa oikea ja järkevä ratkaisu. Hanke oli ongelmiensa vuoksi niin mahdoton, että tuskin sen valmistelijatkaan siihen oikeasti saattoivat uskoa ainakaan annetut lausunnot luettuaan.

Ennen hankkeesta luopumista esitettiin myös sellaisia kannanottoja, joiden mukaan olisi löydettävä korvaavat verot valtion verotulojen turvaamiseksi. Koska vero olisi tuottanut verotuloja korkeintaan 
marginaalisesti, ei uusia korvaavia verotuloja yksin tällä perusteella kannata etsiä. Mutta koska velkaantunut valtio muutenkin tarvitsee verotuloja, käsitellään tässä myös verotulojen lisäämismahdollisuutta kiinnittäen huomiota erityisesti veneisiin.

\subsection{Haittaveroluonteinen venevero}

Jos on perehtynyt veneveroehdotuksesta annettuihin lausuntoihin, ei voi olla vakuuttumatta siitä, että veneverosta olisi tullut "haittavero"; niin haitalliseksi se koettiin.

Haittaverolla kuitenkin yleensä tarkoitetaan veroa, jolla pyritään vähentämään haittoja. Haittaveroilla yritetään torjua esimerkiksi ympäristö- tai terveysongelmia. Tällä valtiovarainministeriössä laaditulla esityksellä oli yksinomaan fiskaalisia tavoitteita. Jos veneilyllä on esimerkiksi merkittäviä ympäristöhaittoja vaikkapa melun tai vesien saastuttamisen vuoksi, olisi laadittava aivan uusi haittaveroehdotus, jossa tarkasti selvitettäisiin veneilystä aiheutuvat haitat ja tutkittaisiin, millainen vero soveltuisi haittojen poistamiseen paremmin kuin esimerkiksi kieltotyyppiset keinot.

\subsection{Ulkomaanliikenteen matkustajaverot}

Merenkulun matkustajaliikenne saa vuosittain noin 250 miljoonaa euroa vero- ja muuta tukea; keskeisimpiä tukia ovat myynnin ja palvelujen arvonlisä- ja valmisteverovapaudet sekä miehistönkustannustuki (Helsingin Sanomissa 8.3.2017 selostettu Tampereen yliopiston tutkimus). Tukea perustellaan ulkomaankaupan huoltovarmuuden, meriosaamisen kilpailukyvyn ja työllisyyden turvaamisella. Merenkulun kansallisia tukia perustellaan globaalilla ja EU-tason tukipolitiikalla.

Veneverokeskustelussa on heitetty sellainenkin ajatus, että ulkomaanmatkoille olisi säädettävä erityisvero. Tämän kirjan historiaosuudessa on selvitetty, miten meillä on ennen EU-jäsenyyttämme 
huonolla menestyksellä kokeiltu laivoilla ja lentokoneilla tehtävien ulkomaanmatkojen matkustajaveroja. EU-aikana tuollaisten kansallisten verojen säätäminen ja soveltaminen olisi vielä vaikeampaa.

\subsection{Varallisuusverotus}

\subsubsection{Varallisuusveron synty, kehitys, hiipuminen ja kuolema ${ }^{5}$}

Todelliseen tuloon perustuvan yleisen tuloveron rinnalle kehitettiin 1800- ja 1900-lukujen vaihteessa Saksassa koko nettovarallisuuden omaisuus- eli varallisuusvero. Pian tuollainen vero otettiin käyttöön useissa valtioissa. Suomessa näin tapahtui vuonna 1918.

Varallisuusvero oli meillä alkuaikoina valtiontaloudellisesti merkittävä. Sen osuus 1920- ja 1930-luvuilla valtion tulo- ja omaisuusveron yhteistuotosta oli 20-30\%, ja omaisuusveron tuotosta kaksi kolmasosaa kertyi osakeyhtiöiltä. Kansalaisten varallisuus kasvoi, mutta varallisuusveron tuotolle kävi päinvastoin. Varallisuusvero alkoi voimakkaasti hiipua 1960-luvulla, kun se poistettiin osakeyhtiöiltä. Vähitellen varallisuusverotusta lievennettiin niin, että 2000-luvulla sen tuotto oli jo erittäin vaatimaton. Varallisuusveron heikkoon tilaan vaikuttivat verokannan alentamisen lisäksi muun muassa laajat verovapaudet ja omaisuuden varovainen arvostus.

Varallisuusveroa määrättiin vuodelta 2003 vain noin 120 miljoonaa euroa. Verovelvollisten verotettavasta bruttovarallisuudesta $77 \%$ muodostui kiinteistöistä, asunto-osakkeista sekä maa- ja metsätalouden varallisuudesta. Loppuosa muodostui lähinnä arvopapereista, joista pääosa oli osakkeita. Useat maat olivat luopuneet varallisuusverotuksesta.

Alun perin veronalaisten varojen piiri oli ollut laaja ja sisältänyt myös moottoriveneet. Veronalaisiksi ei kuitenkaan katsottu esimerkiksi tavallisia soutuveneitä ja ruuhia sekä koiria, sikäli kuin nämä

5 Esko Linnakangas - Leila Juanto, Verojen historia (2006) s. 69-79. 
eivät olleet luxusluontoisia. ${ }^{6}$ Ennen kesällä 2004 säädettyä muutosta varallisuusveron alaisina mainittiin laissa muun muassa autot, moottoripyörät ja moottoriveneet sekä purjeveneet. Vuosina 2004 ja 2005 veronalaisia eivät enää olleet tavanomaiset verovelvollisen omassa tai perheen käytössä olevat kulkuneuvot.

Yritys- ja pääomaverouudistuksen myötä osakeomistuksen verotus kiristyi, kun yhtiöveron hyvitysjärjestelmästä luovuttiin ja siirryttiin osinkona jaetun voiton osittaiseen kahdenkertaiseen verotukseen. Osinkoverotuksen muutos antoi aiheen tarkistaa osakeomistukseen kohdistuvan verotuksen kokonaisuutta. Omistuksen verottamisen sijasta pidettiin tarkoituksenmukaisempana kohdistaa osakeomistuksen verotus tuoton eli osinkojen verotukseen. Siksi osakevarallisuuden varallisuusverotuksesta ehdotettiin luovuttavaksi.

Pelkkä osakkeiden varallisuusverotuksesta luopuminen olisi merkinnyt sitä, että varallisuusveroa olisi kertynyt lähinnä enää kiinteistövarallisuudesta, joka oli ja on yhä kiinteistöverotuksen piirissä. Kiinteistöverotuksen taustanäkökohdat olivat osin toiset kuin ne olivat varallisuusverotuksessa, mutta yhteistä kummallekin veromuodolle oli se, että vero kohdistui varallisuuteen sen todellisesta tuotosta riippumatta. Osakkeiden varallisuusverotuksesta luopumisen jälkeen ei ollut - myös varallisuusverotuksen hallinnolliset kustannukset huomioon ottaen - syytä ylläpitää kiinteistöjen verotuksessa kahta päällekkäistä veromuotoa.

Hallitus esitti varallisuusverotuksesta luopumista vuoden 2006 alusta, ja eduskunnassa esitys hyväksyttiin äänestyksen jälkeen. Sen jälkeen Suomessa ei ole ollut vakavia pyrkimyksiä yleisen varallisuusverotuksen palauttamiseksi. Yleisen varallisuusverotuksen henkiin herättäminen pelkästään siksi, että veneveron säätäminen epäonnistui, tuntuu perusteettomalta ja muutenkin mahdottomalta. Varallisuusvero voi kuitenkin vielä jossakin muodossa palata, jos esimerkiksi pääomaverotusta halutaan lisätä, jotta olisi varaa vastaavasti alentaa ansiotulojen verotusta. Varallisuusveroa, kuten myös pääomatulojen

6 Näin Aarne Rekola, Tulo- ja omaisuusverolaki (1947) s. 305. Oikeuskirjallisuuden mukaan moottoriveneinä ei ollut pidettävä sellaisia avoimia veneitä, joissa voitiin käyttää pienehköä ulkolaitamoottoria. Edward Andersson - Esko Linnakangas, Tulo- ja varallisuusverotus (2002) s. 446. 
verotuksen tiukentamista, puolletaan voimakkaasti professori Thomas Pikettyn laajassa ja paljon huomiota saaneessa tutkimuksessa "Päöoma 2000-luvulla". Kirja ilmestyi alun perin ranskaksi vuonna 2013, ja suomennos ilmestyi vuonna 2016.

\subsubsection{Varallisuuden verottamistavoista ja hyödykekohtaisesta varallisuusverosta}

Verotuksen perustehtävä on varojen saaminen valtiolle ja muille julkisyhteisöille niiden tehtävien suorittamiseksi. Varoja on saatavissa niiltä veronmaksajilta, joilla varoja on. Varallisuus onkin luonnollisimpia ja vanhimpia verotuskohteita. Joskus on myös sanottu, että veroja on perittävä varallisuudesta siksi, että valtio turvaa varallisuutta. Kysymys siis olisi tavallaan vakuutusmaksuista tai suojelurahoista. Varallisuuden veroja voidaan luokitella monella tavalla, esimerkiksi seuraavasti: ${ }^{7}$

Yleiset ja osittaiset varallisuusverot. Yleisillä varallisuusveroilla pyritään verottamaan koko varallisuutta, kun taas osittaiset varallisuusverot kohdistuvat vain tiettyyn varallisuuden osaan, kuten kiinteistöomaisuuteen tai elinkeino-omaisuuteen.

Nimelliset ja todelliset varallisuusverot. Nimellisissä eli epäaidoissa varallisuusveroissa veron kohteena on omaisuuden tuotto. Nimelliset varallisuusverot ovat pääasiassa tuloveron täydennysveroja eli vakautetun tulon lisäveroja. Todellista eli aitoa varallisuusveroa taas kannetaan kantavarallisuudesta, ei sen tuotosta.

Luonnollisten henkilöiden ja yhteisöjen varallisuusverot. Luonnollisten henkilöiden varallisuusverot kohdistuvat fyysisten henkilöiden eli ihmisten varoihin, kun taas yhteisöjen varallisuusvero kohdistuu juridisten henkilöiden varoihin.

Objektiiviset ja subjektiiviset varallisuusverot. Objektiiviset varallisuusverot eivät ota huomioon luonnollisten henkilöiden henkilökohtaisia olosuhteita, kun taas subjektiivisissa varallisuusveroissa on esimerkiksi verovapaa minimi ja huomiota saavat myös perhesuhteet.

Bruttovarallisuuden ja nettovarallisunden varallisuusverot. Nettovarallisuusveroissa, toisin kuin bruttovarallisuusveroissa, varallisuudesta vähennetään velat.

Klaus Tipke, Die Steuerrechtsordnung (1993) s. 770-771. 
Kulutusvarallisuusverot ja elinkeinovarallisuusverot. Kulutusvarallisuusverot kohdistuvat yksityisessä kulutuksessa olevaan varallisuuteen, elinkeinovarallisuusveroja kannetaan liike- ja ammattivarallisuudesta.

Kauppa-arvoon ja tuottoarvoon perustuvat varallisuusverot. Edellisten pohjana on omaisuuden vaihtoarvo, jälkimmäiset määräytyvät omaisuuden tuottokyvyn mukaan.

Yleinen verovelvollisen kaikkien varojen ja velkojen erotukseen kohdistuva varallisuusvero ei siis ole ainoa tapa järjestää varojen verottaminen. Jos valtiovarainministeriössä valmisteltua veneveroehdotusta tarkastellaan edellä olevan luokituksen pohjalta, venevero olisi osittainen objektiivinen bruttovarojen mukaan määräytyvä kulutusvarallisuusvero. Toista tuollaista veroa ei nykyinen verojärjestelmämme tunne. Vero tuo mieleen lähinnä 1700-luvun ylellisyysverot.

Yksi veneveroehdotuksen keskeinen ongelma oli se, ettei vero olisi määräytynyt veneen todellisen arvon ja käyttöajan perusteella. Jos halutaan säätää arvoperusteinen venevero, olisi harkittava sen kantamista esimerkiksi tuloverotuksen yhteydessä. Tässä mallissa verovelvollisen olisi vuosittain tuloveroveroilmoituksessa ilmoitettava eriteltynä kaikki omistuksessaan tai hallinnassaan olevat veneet, niiden jokaisen arvo erikseen sekä kunkin veneen kohdalla tieto siitä, kuinka monena kuukautena vene on ollut vedessä eli käytettävissä. Sillä, onko kysymyksessä moottorivene vai purjevene, ei olisi merkitystä. Jottei veneelle ilmoitettaisi liian alhaista arvoa, voitaisiin ehkä myös pohtia säädettäväksi valtiolle oikeus lunastaa ja myydä vene verovelvollisen ilmoittamasta arvosta. Veneen arvosta ennen veron laskemista tehtäisiin kiinteä euromääräinen vähennys, jolloin halvimmat veneet kokonaan säästyisivät verolta ja verotus olisi progressiivista. Koska soutuveneet jäisivät kiinteän vähennyksen vuoksi verotuksen ulkopuolelle, ne voitaisiin säätää suoraankin verovapaiksi. Varallisuusverotuksessa ylin marginaalivero oli 2000-luvun alussa noin $1 \%$.

Voitaisiin ajatella esimerkiksi seuraavaa mallia, jossa veneen arvosta tehtävä kiinteä vähennys olisi 5000 euroa ja veroprosentti 0,1\% kuukaudessa. Jos siis 12000 euron arvoinen vene on ollut verovuonna vedessä kuusi kuukautta, vero olisi 42 euroa eli 0,6 x (12 000 5 000). Jos veneen arvo olisi 100000 euroa ja vene olisi vedessä viisi kuukautta, vero olisi 475 euroa eli 0,5 x (100 $000-5000)$. Veroon ei 
olisi vaikutusta sillä, minkä valtion vesillä vene olisi ollut. Jos vene ei olisi ollut vedessä lainkaan, ei siitä menisi myöskään veroa. Vero voitaisiin periä valtiolle tuloveron yhteydessä, kuten yleisradiovero. Sitä ei siis perisi esimerkiksi Trafi venerekisterin perusteella. Venerekisteriä voitaisiin käyttää vain sen selvittämisessä, onko henkilön omistuksessa ylipäänsä veneitä. Valvontaa, johon ei kannattaisi veron vähäisen fiskaalisen merkityksen vuoksi liikaa satsata, hoitaisi tuloverovalvonnan yhteydessä Verohallinto.

Jos tällaisen mallin mukainen verokokeilu onnistuisi, voitaisiin harkita vastaavaa verotusta myös vaikkapa moottoripyöriin ja hevosiin. Vaikka olen nyt tällaisen veneveromallin luonnostellut, en esitä lainvalmistelun aloittamista sen pohjalta. Valtion verotulot voidaan kerätä tarkoituksenmukaisemmin jo voimassa olevilla veroillamme, joita käsittelen seuraavaksi,

\subsection{Tuloverotus}

\subsubsection{Tuloveron synty ja kehitys ${ }^{8}$}

Maaverot ja muut arvioituun tuottoon perustuvat verot ovat hyvin vanhoja veroja. ${ }^{9}$ Vielä 1800 -luvun alussa valtion verotuloista noin 70 \% kertyi niistä. Varsinaiset maaverot lakkautettiin Suomessa vuonna 1925. Niiden sukulainen kunnallinen kiinteistövero sen sijaan voi hyvin, ja sille ennustetaan entistäkin parempia aikoja, koska kiinteistöverotus ei anna samanlaisia mahdollisuuksia kansainväliseen veropakoon kuin tuloverotus; kiinteistöthän eivät voi siirtyä valtiosta toiseen juuri muutoin kuin sotien seurauksena.

Nettotuloon perustuvan tuloverotuksen lähtölaukauksena yleensä pidetään Isossa-Britanniassa vuonna 1799 Napoleonia vastaan käydyn sodan rahoittamiseksi säädettyä tilapäistä veroa. Jatkuvasti tuloverotus on ollut Isossa-Britanniassa käytössä vuodesta 1842. Ison-

Esko Linnakangas - Leila Juanto, Verojen historia (2016) s. 281-304.

9 Maaverojemme vanhemmasta historiasta ks. erityisesti Suvianna Seppälän vuonna 2009 tarkastettu väitöskirja Viljana, nahkoina, kapakalana - Talonpoikien maksamat kruununverot Suomessa vuosina 1539-1609. 
Britannian vero ei kuitenkaan perustunut kokonaistuloon vaan tulon lähteisiin.

Vuosi 1865 oli merkittävä Suomen verohistoriassa. Tuolloin annettiin Keisarillisen Majesteetin Armollinen Julistus siitä suostuntaverosta, jonka Suomenmaan säädyt olivat ottaneet maksaakseen. Valtion tuloveroa kutsuttiin nimellä "suostunta", kuten yleensä muitakin sellaisia veroja, joita hallitsija ei voinut määrätä ilman säätyjen suostumusta.

Näin säädettiin Suomessa ensi kertaa yleinen kokonaistuloon perustuva tuloverotus. Se tapahtui samaan aikaan kuntauudistuksen ja tuloveroperusteisen kunnallisveron säätämisen kanssa. Jokaisen tuli "suostuntawerokomitealle ilmoittaa, kuinka suureksi hän arvaa puhtaan tulonsa wiimeksi kuluneelta wuodelta". Ilmoittamisvelvollisuuden merkitys jäi todellisuudessa vähäiseksi, koska verovelvollisen ilmoitusvelvollisuutta ei ollut sanktioitu veronkorotuksella.

Tulojen todellinen määrä jäikin usein verovelvollisen moraalin varaan, joten verotus muistutti nykyistä arvioverotusta. Valtion tuloverotuksen tuotot jäivät hyvin vähäisiksi, ja tuloverosta luovuttiin vuoden 1885 valtiopäivillä. Tuolloin korostettiin, että tuloverorasituksen kohdistuminen oli erittäin epätasaista, minkä vuoksi tuota veroa kannatti käyttää vain tilanteissa, joissa muut lähteet eivät riittäneet. Viitattiin myös järjestelmän aiheuttamiin kohtuuttoman suuriin kuluihin.

Käsitys valtion yleisen tuloveron tarpeellisuudesta vahvistui 1800-luvun lopussa ja 1900-luvun alussa, ja mallia haettiin erityisesti Saksasta. I maailmansodan rahoittamiseen käytettiin Suomessa lainanoton lisäksi niin sanottuja sotaveroja, jotka otettiin alun perin käyttöön eduskunta sivuuttaen. Ensimmäinen sotavero, joka liittyi tuloverotukseen, oli vuonna 1915 määrätty pääoma- ja kuponkivero. Sotaveroista tuottoisin oli väliaikainen suurten tulojen vero, joka oli progressiivinen ja nousi korkeimmillaan $10 \%$ :iin. Jos tulot olivat edellisvuosista suuresti nousseet, oli maksettava ankarampaa veroa, joka oli suurimmillaan $25 \%$.

Suomessa on ollut pysyvä valtion tulo- ja omaisuusverotus vuodesta 1920 alkaen. Uuteen sotaan varautuminen näkyi muun muassa vuonna 1938 säädetyssä lisäverossa armeijan perushankintoihin. Sen mukaan tulo- ja omaisuusveroa korotettiin $20 \%$. Heti talvisodan 
syttymisen jälkeen korotettiin vuodelta 1939 maksuunpantavaa tuloveroa $20 \%$ ja omaisuusveroa $50 \%$, ja korotukset olivat käytössä myös vuosina $1940-1942$.

Sotien jälkeen Suomen talous alkoi kehittyä voimakkaasti, mutta tuloverotus ja muukin verotus säilyivät ankarina. Sodasta aiheutuneiden kustannusten ja muiden sellaisten menojen lisäksi veroille oli muutakin käyttöä, kun Suomea alettiin kehittää entistä selvemmin kohti hyvinvointiyhteiskuntaa. Vuoden 1967 alusta valtionverotuksen veroasteikkoja korotettiin. Kun nämä asteikot olivat muuttamattomina voimassa vuoden 1973 loppuun asti, inflaatio lisäsi progressiivisen asteikon perusteella tuloverotusta jatkuvasti.

Suomen tuloverojärjestelmää uudistettiin voimakkaasti 1980-luvun lopun taloudellisella nousukaudella. Niin sanotussa kokonaisverouudistuksessa vuodesta 1989 alkaen veropohjaa laajennettiin ja valtion veroasteikkoa alennettiin. Verojärjestelmän neutraalisuutta pyrittiin lisäämään ja sen ohjailuvaikutuksia samalla vähentämään. Oppia haettiin USA:n presidentti Reaganin verouudistuksesta.

Talouslaman aikana vuonna 1991 aloittanut hallitus asetti tavoitteekseen, että verotuksen uudistamista jatkettaessa otetaan huomioon myös verojärjestelmämme kansainvälinen kilpailukyky. Vuoden 1993 alusta meillä siirryttiin niin sanottuun eriytettyyn tuloverojärjestelmään. Siinä ansiotulot säilyivät progressiivisen verotuksen piirissä, mutta pääomatuloihin alettiin soveltaa yhtenäistä suhteellista verokantaa. Pääomatulojen verokannaksi säädettiin aluksi $25 \%$, ja samalla yhteisöverokanta alennettiin $25 \%$ :iin. Nuo verokannat olivat kansainvälisestikin hyvin alhaisia eli kilpailukykyisiä.

Vuoden 1993 alussa tuli voimaan myös nykyinen kiinteistöverolakimme. Sillä korvattiin neljä instituutiota: asuntotulon verotus, kiinteistöjen harkintaverotus, katumaksu ja manttaalimaksu. Kiinteistövero määräytyy kiinteistön arvon perusteella. Kiinteistövero ei perustu tuloveron tavoin verovelvollisen maksukykyyn, vaan siinä näkyy vahvemmin etuperiaate, joka nykyisin liitetään enemmän maksuna kuin verona pidettävään suoritukseen.

Ansiotulojen verotuksessa tapahtuneet lainmuutokset ovat olleet viime vuosina melko pieniä. Pääomatulojen verokantaa on kiristetty, ja suurten pääomatulojen verotus on muutettu verovuodesta 2012 alkaen lievästi progressiiviseksi (v. 2015 verokanta oli 30-33 \% ja 
v:sta 2016 ylin vero on $34 \%$ ). Osakeyhtiöiden ja muiden yhteisöjen verokantaa on meillä viime vuosina alennettu hyvin merkittävästi, kuten on tehty monissa muissakin valtioissa. Vuodesta 2014 alkaen se on ollut vain $20 \%$, joka on alle puolet siitä, mikä se oli vielä 1980-luvulla.

Viime aikojen kehityksessä hyvin merkittävää on ollut tuloverotusmenettelyn automatisointi. Harvan verovelvollisen tarvitsee enää antaa veroilmoitusta, kun nykyisin tietokoneet tietävät ihmisten tulot paremmin kuin ihmiset itse. Luottamusmiespohjaisesta lautakuntaverotuksesta on siirrytty virkailijaverotuksen kautta koneverotukseen. Veropolitiikassa on progressiivisen tuloveron suhteellista merkitystä vähennetty korottamalla kulutusveroja, jotka ovat tasaveroja tai henkilöiden tulotasoon nähden regressiivisiä. Vaikka suuntaus on historiallisesti taantumuksellinen, vielä ollaan kaukana 1800- ja 1900-lukujen vaihteesta, jolloin valtion verotuloista noin $90 \%$ perustui välilliseen verotukseen.

Tuloverojärjestelmää 1800- ja 1900-lukujen vaihteessa luotaessa veroaste oli nykyiseen verrattuna kovin vaatimaton. Silloin saatettiin vakavastikin keskustella siirtymisestä yhteen veroon, joka olisi progressiivinen tulovero. Esimerkiksi Suomen Sosialidemokraattisen Puolueen Forssan kokouksessa vuonna 1903 tavoitteeksi asetettiin "kaikkien henkilöllisten ja välillisten verojen poistaminen yleisellä asteettain nousevalla tuloverolla, jolloin ansioton arvonnousu ja korkotulot sekä perintö on verotettava ankarammin kuin omasta ansiosta tai työstä johtuvat tulot”.

Vaikka tuloveroa saatetaan kutsua kuningasveroksi, yksinvaltiasta ei siitä ole koskaan tullut, eikä siitä sellaista ole tulossakaan. Arvonlisävero on nykyisin valtion verotuloista tuottoisin. Valtion ja kuntien tuloverot ovat yhteensä noin 31,5 miljardia euroa vuodessa, joten tulovero on kyllä nykyisin fiskaalisesti Suomen tärkein vero.

\subsubsection{Osinkoverotuksen uudistaminen}

Pohdittaessa veneveron korvaavia veroja on yhtenä vaihtoehtona otettu esille myös nykyisen osinkotulojen verotuksen uudistaminen. Osinkotulojen verotuksessa meillä siirryttiin 1980- ja 1990-lukujen 
vaihteessa monessa maassa jo aiemmin käyttöön otettuun yhtiöveron hyvitysjärjestelmään, jolla poistettiin osinkotulojen kahdenkertainen verotus mutta samalla varmistettiin yhdenkertainen verotus. Vuonna 2005 osinkoverotuksessa luovuttiin eurooppaoikeudellisesti ongelmallisesta yhtiöveron hyvitysjärjestelmästä ja osingot saatettiin osittain kahdenkertaisen verotuksen piiriin, mutta pienten ja keskisuurten yritysten ja niiden maksamien osinkojen verotusta ei kiristetty. Uusi osinkoverojärjestelmä oli luonnollisten henkilöiden listaamattomista yhtiöistä saamien osinkojen osalta tavattoman monimutkainen ja monessa tapauksessa osingonsaajien osalta huomattavan edullinen.

Valtioneuvoston kanslian tammikuussa 2017 julkaistussa raportissa "Yritysverotus, investoinnit ja tuottavuus" arvioitiin Suomen nykyisen yritys- ja pääomatuloverotuksen ongelmia ja kehittämisvaihtoehtoja investointikannusteiden, taloudellisen tehokkuuden ja tuottavuuden näkökulmista. Suomen osinkoverotuksen ilmeisimpänä ongelmana oli listaamattomista yhtiöistä saatavien osinkojen veroasteen vaihtelu. Nykyiseen verojärjestelmään liittyvä $8 \%$ :n tuottoraja todettiin hyvin korkeaksi verrattuna markkinakorkoihin, ja sitä ehdotettiin alennettavaksi lähemmäs markkinakorkoja.

Helmikuussa 2017 raporttinsa jättäneen yritysverotuksen asiantuntijaryhmän kanta oli samansuuntainen. Siinä ehdotettiin listaamattomien yhtiöiden jakaman osingon verotuksessa huojennetun osingon laskennassa käytettävää tuottoastetta alennettavaksi $4 \%$ :iin, tähän tuottorajaan asti pääomatulona verotettavan osinkotulon veronalaisuusasteen korottamista $40 \%$ :iin ja sen euromääräisen ylärajan poistamista. Muutoksen arvioitiin lisäävän vuotuisia verotuloja 288 miljoonalla eurolla, joka ehdotettiin lähes kokonaan käytettäväksi hyvätuloisten saamien ansiotulojen veroprogression lieventämiseen.

Osinkoverotuksen tiukentaminen on saanut nykyisessä hallituksessa kielteisen vastaanoton keskustalta ja kokoomukselta. Sen sijaan perussuomalaiset ovat suhtautuneet asiaan ymmärtäväisemmin. Osinkotulojen verotusta on voitu vaatia tiukennettavaksi myös siten, että osinkotulojen verovapaus poistettaisiin työmarkkinajärjestöiltä, puolueilta ja muiltakin yleishyödyllisiltä yhteisöiltä. 


\subsubsection{Työmarkkinajärjestöjen jäsenmaksujen vähennysoikeuden rajoittaminen}

Valtion taloustilanteen parantamiseksi kuulee ehdotettavan muun muassa kansanedustajien ja virkamiesten määrän vähentämistä, puoluetukien ja kehitysavun poistamista sekä luopumista ammattiyhdistysten jäsenmaksujen vähennysoikeudesta. Tässä verotusta käsittelevässä kirjassa näistä tarkastellaan vain jäsenmaksujen verovähennystä.

Työmarkkinajärjestöjen jäsenmaksut olivat pitkään vähennyskelvottomia sekä työntekijöiden että työnantajien verotuksessa. Tätä perusteltiin sillä, että järjestöt osallistuvat yhteiskunnalliseen taistelutoimintaan, kuten palkkataisteluihin. Työmarkkinajärjestöjen tukiessa tiettyjä puolueita jäsenmaksujen vähennyskelpoisuuden voidaan myös sanoa merkitsevän piilopuoluetukea.

Työmarkkinajärjestöjen jäsenmaksut on säädetty vähennyskelpoisiksi vuodesta 1969 alkaen. Verokohtelu on edullinen, koska jäsenmaksut ovat verovapaata tuloa yleishyödyllisinä pidettäville työmarkkinajärjestöille. Palkansaajien verotuksessa jäsenmaksut nauttivat erityiskohtelua sikäli, että verotuksen yksinkertaistamiseksi säädetty kaavamainen tulonhankkimisvähennys myönnetään palkansaajille työmarkkinajärjestöjen jäsenmaksujen vähentämisen lisäksi.

Nettotulolle rakentuva tuloverojärjestelmämme perustuu ajatukseen, jonka mukaan tulonhankkimismenoina ei saa vähentää elantokustannuksia ja muita vastaavia menoja. Jäsenmaksun täydellistä vähennysoikeutta voidaan tästä näkökulmasta kritisoida silloin, kun jäsenyydellä rahoitetaan toimintaa, jonka maksuja verovelvollinen ei voisi vähentää maksaessaan ne itse suoraan.

Työmarkkinajärjestöjen jäsenmaksujen vähentämisen lasketaan merkitsevän parinsadan miljoonan euron vuotuista verotukea. Verotulojen lisäykseen pyrittäessä saatetaan kysyä, onko työmarkkinajärjestöjen jäsenmaksujen välttämättä oltava kokonaan vähennyskelpoisia. On-off-periaate ei ole ainoa mahdollinen verotuksessakaan. 
Voitaisiin harkita mallia, jossa vähennyskelpoista olisi kaavamainen osuus, vaikkapa puolet jäsenmaksusta. ${ }^{10}$ Puolittaminen on jo todettu hyväksi ratkaisuksi edustusmenojen vähennysoikeudessa. Vähennysoikeuden osittaminen on tuttua myös asuntolainojen koroissa.

Sellainen "kompromissi", jossa työnantajat saisivat verotuksessaan vähentää omat jäsenmaksunsa mutta työntekijät eivät omia jäsenmaksujaan, voisi panna työntekijät kyselemään perustuslaissakin mainitun yhdenvertaisuuden perään. Työnantajat taas tuskin pitäisivät tasapuolisena järjestelmää, jossa työnantajan jäsenmaksujen verovähennysoikeuden euromääräinen katto olisi sama kuin työntekijällä (esim. 150 euroa vuodessa).

Heinäkuussa 2014 julkaistussa gallupissa (HS 24.7.2014 s. A 14) kysyttiin kannanottoa väitteeseen, jonka mukaan ammattiliiton jäsenmaksuista saatavasta verovähennysoikeudesta tulisi luopua. Suurimpien puolueiden kannattajien vastaukset jakautuivat prosentteina seuraavasti:

\begin{tabular}{|l|c|c|c|c|c|}
\hline & $\begin{array}{c}\text { Täysin } \\
\text { samaa } \\
\text { mieltä }\end{array}$ & $\begin{array}{c}\text { Osittain } \\
\text { samaa } \\
\text { mieltä }\end{array}$ & $\begin{array}{c}\text { Ei osaa } \\
\text { sanoa }\end{array}$ & $\begin{array}{c}\text { Osittain } \\
\text { eri mieltä }\end{array}$ & $\begin{array}{c}\text { Täysin eri } \\
\text { mieltä }\end{array}$ \\
\hline Kok. & 35 & 20 & 11 & 15 & 19 \\
\hline SDP & 7 & 3 & 9 & 19 & 62 \\
\hline PS & 13 & 13 & 13 & 16 & 45 \\
\hline Kesk. & 19 & 18 & 6 & 20 & 37 \\
\hline Vas. & 5 & 4 & 13 & 18 & 60 \\
\hline Vihr. & 9 & 8 & 15 & 28 & 40 \\
\hline Kaikki & 14 & 12 & 15 & 19 & 40 \\
\hline
\end{tabular}

Mielipiteet siis riippuivat voimakkaasti puoluekannasta. Kompromissina voitaisiin harkita vähennysoikeuden osittamista. Osittainen vähennysoikeus voisi sopia ainakin niille, jotka ovat vähennysoikeu-

10 Esko Linnakangas, Puolittaminen jäsenmaksujen verovähennykseen? Verotus 2015 s. 550-551. 
den poistamisesta osittain samaa mieltä tai osittain eri mieltä taikka eivät osaa sanoa.Näihin ryhmiin kuuluvien vastaajien yhteisosuus oli kyselyssä kaikkiaan melkein puolet.

Kristillisdemokraatit, joiden kanta ei näkynyt edellä olevassa tilastossa, ovat vuoden 2016 lopulla esittäneet ammattiliittojen jäsenmaksujen verovähennysoikeuden puolittamista ja työnantajaliittojen jäsenmaksujen verovähennysoikeuden poistamista kokonaan, joilla toimenpiteittä saataisiin 127,5 miljoonan euron säästöt. Puolueen puheenjohtaja Sari Essayah ei usko, että liitoissa tulisi jäsenkatoa, vaikka jäsenmaksujen verovähennysoikeuteen puututtaisiin.

\subsection{Arvonlisäverokantojen korottaminen}

Arvonlisäveroa suoritetaan lähtökohtaisesti kaikesta liiketoiminnan muodossa tapahtuvasta tavaran ja palvelun myynnistä. Arvonlisäverolain 4 luvussa on säädetty poikkeuksia myynnin verollisuudesta. Arvonlisäveroa ei ole suoritettava esimerkiksi kiinteistönluovutuksista, terveyden- ja sairaanhoidosta, sosiaalihuollosta, koulutuksesta, hengellisestä avusta, rahoituspalveluista, sijoituskullasta, vakuutuspalveluista ja yleishyödyllisen yhteisön jäsenlehden painoksesta.

Vesialuksia koskevan AVL 58 \$:n mukaan veroa ei suoriteta sellaisten vesialusten myynnistä, vuokrauksesta tai rahtauksesta, joiden rungon suurin pituus on vähintään 10 metriä ja jotka eivät ole rakenteeltaan pääasiallisesti huvi- tai urheilukäyttöön tarkoitettuja. ${ }^{11}$ Arvonlisäveroa ei suoriteta myöskään mainittuihin verottomiin vesialuksiin sekä tällaisesta aluksesta korjattavaksi irrotettuihin osiin kohdistuvan työsuorituksen sekä työhön käytetyn ja työn yhteydessä alukseen asennetun tavaran myynnistä. AVL 114.1 \$:n 5 kohdan mukaan vähennystä ei saa tehdä, jos kysymys on rakenteeltaan pääasiallisesti huvi- tai urheilukäyttöön tarkoitetuista vesialuksista tai niiden käyttöön liittyvistä tavaroista ja palveluista. Vähennysoikeuden

11 Yhteisöhankintana verotetaan myyjän ja ostajan asemasta riippumatta uudet vesialukset, jos ne ovat yli 7,5 metriä pitkiä (AVL 26d \$). Tämä ei kuitenkaan koske aluksia, jotka AVL 58 \$:n mukaan voidaan myydä verotta. 
rajoitus ei koske alusta, joka on hankittu myytäväksi, vuokrattavaksi taikka käytettäväksi ammattimaiseen henkilökuljetukseen tai ajoopetukseen.

Verollisten tavaroiden ja palvelujen arvonlisäverokanta on nykyisin AVL 84 \$:n mukaan $24 \%$, ellei hyödyke kuulu alennettujen verokantojen piiriin. EU:n direktiivi ei salli normaaliverokantaa korkeampaa verokantaa millekään tuotteelle. Jos esimerkiksi huviveneille haluttaisiin ankarampi verotus, olisi käytettävä sellaisia veroja, jotka eivät ole arvonlisäveron kaltaisia. Kysymykseen voisi tulla vaikkapa veneen arvoon tai teknisiin ominaisuuksiin pohjautuva kansallinen valmistevero edellyttäen, ettei se rajoita ihmisten ja tavaroiden vapaata liikkuvuutta Euroopassa.

AVL 85 §:ssä luetellaan hyödykkeet, joihin sovelletaan $14 \%$ :n verokantaa. Niitä ovat elintarvikkeet sekä ravintola- ja ateriapalvelut. Elävät eläimet, vesijohtovesi, alkoholijuomat ja tupakkavalmisteet sekä myrkyt verotetaan kuitenkin normaaliverokannalla. Elintarvike on ruokatavara, juoma ja muu sellaisenaan ihmisen nautittavaksi tarkoitettu aine sekä niiden raaka-aine ja niitä valmistettaessa tai säilöttäessä käytettävä mauste, säilöntäaine, väri- sekä muu lisäaine. $14 \% . n$ verokannalla verotetaan myös rehuaineet. Niitä ovat rehu ja rehuseos sekä niiden valmistuksessa käytettäväksi tarkoitettu raaka- ja lisäaine, eläinten ruokana käytettävät teollisuuden jäteaineet sekä rehukala.

Seuraavat tavarat ja palvelut ovat AVL 85a \$:n mukaan $10 \%$ :n verokannan piirissä:

- henkilökuljetus (veroa ei kuitenkaan suoriteta henkilökuljetuksesta, joka tapahtuu suoraan ulkomaille tai ulkomailta);

- majoitustilan tai käyntisataman ${ }^{12}$ käyttöoikeuden luovuttaminen;

12 KHO 2016:40. Yhtiö ylläpiti pienvenesatamaa. Yhtiön osake oikeutti yhden venepaikan hallintaan ao. pienvenesatamassa. Yhtiö veloitti osakkaaltaan vastikkeen, joka sisälsi venepaikan lisäksi mm. sähkön, veden, jätehuollon, satama-alueen vartioinnin sekä sen varmistamisen, että laiturit olivat kaikilta osin kunnossa ja veneilijöiden käytössä. Koska yhtiön osakkaalla oli oikeus käyttää kiinteistöä, siis venepaikkaa, omistusoikeutensa perusteella, yhtiön toiminta ei tältä osin ollut verollista pysäköintitoiminnassa tapahtuvaa pysäköintipaikan tai sataman luovuttamista, vaan se oli kiinteistöön kohdistuvan oikeuden verotonta luovuttamista (äänestys 3-2). 
- palvelu, jolla annetaan mahdollisuus liikunnan harjoittamiseen; teatteri-, sirkus-, musiikki- ja tanssiesitysten, elokuvanäytösten, näyttelyjen, urheilutapahtumien, huvipuistojen, eläintarhojen, museoiden sekä muiden vastaavien kulttuuri- ja viihdetilaisuuksien ja laitosten pääsymaksut, mukaan lukien myös huvipuistojen ajolaitteiden ja muiden vastaavien laitteiden käytöstä perittävät pääsymaksunluonteiset maksut;

- Yleisradion saama märä valtion televisio- ja radiorahastosta;

- lääkkeet;

- kirjat; kirjana ei pidetä muulla tavalla kuin painettuna tai siihen verrattavalla tavalla valmistettua julkaisua, kausijulkaisua tai pääasiallisesti mainoksia sisältävää julkaisua;

- sanoma- ja aikakauslehdet vähintään kuukauden ajaksi tilattuina;

- taide-esineet tietyin edellytyksin;

- eräät tekijänoikeuteen liittyvät korvaukset; tietyt tekijänoikeudet ovat verottomia.

Yleisen kulutusverotuksen verokantaa on jatkuvasti nostettu. Liikevaihtoveroa perittiin vuonna 1964 vain $10 \%$ verollisesta hinnasta. Sittemmin verokantaa on korotettu vaiheittain niin, että arvonlisäverotuksen yleinen verokanta on ollut vuoden 2014 alusta jo $24 \%$ verottomasta hinnasta. Verokantamme on kansainvälisesti hyvin korkea, edellämme on vain pari maata. Pieni yleisen verokannan korotus saattaa olla meillä vielä edessä valtion verotulojen lisäämiseksi. Yleisen arvonlisäverokannan korottaminen voidaan kuitenkin välttää alennettujen verokantojen korottamisella, johon lähivuosina hyvinkin saatetaan turvautua. 


\subsection{Polttoaineveron korottaminen ja verotuksen ikuisuus}

Polttoaineveron korotus on helppo ratkaisu myös pohdittaessa veneveron korvikkeita, koska polttoaineveron minimaalisen korotuksen hintavaikutukset jakautuvat niin laajalle, ettei yksittäinen kuluttaja muutosta edes huomaa. Polttoaineveron korotuksella on kompensoitu makeisveronkin poistaminen. Loputtomiin ei polttoaineverolla kuitenkaan voida korvata muita veroja. Fossiilisista polttoaineista kannettava vero loppuu viimeistään fossiilisten polttoaineiden loppuessa.

Elämässä varmaa on vain kuolema ja verotus. Tähän tapaan totesi vuonna 1789 Benjamin Franklin (1706-1790) kirjeessä, joka koski USA:n perustuslakia. Samantapainen väite löytyy monista vanhemmistakin lähteistä, ja se on yleinen tänäkin päivänä. Se mainitaan myös Jeff Koonin ja Andy Powellin 2000-luvun alussa julkaistun teoksen "Alligaattoria ei saa sitoa vesipostiin - 101 todella tyhmää lakia"13 esipuheessa. Tuossa pikku kirjassa keskitytään amerikkalaisiin lakeihin eikä mainita mitään Suomen verolaeista.

Vaikka verotuksen voidaan sanoa olevan ikuista, verolajit ja verotustavat eivät ole pysyviä, minkä tämäkin tutkimus vahvistaa.

13 Englanninkielinen alkuteos You May Not Tie an Alligator to a Fire Hybrant. 101 Real Dumb Laws. 


\section{Asiahakemisto}

A

ajoneuvovero 51,79

alkoholivero $15,19,25,70$

arvonlisävero 70,178

autokumirengasvero 53

autovero 54

C

chartervero 68

E

elintarvikevero 35

elokuvavero 47

elv 79

H

haittavero 111,166

hinnantasausmaksu 33, 56

hopeavero 45

huvivero $18,24,47$

J

junavero 23, 82

jätevero 76

jäätelövero 75

K

kahvivero 17,30

koiravero 14, 18, 20, 46

kultavero 45 kulutusvero 13

käyttömaksu 52

käyttövero 151

käyttövoimavero 52

$\mathbf{L}$

lannoitevero 39

liikevaihtovero 62

liikevaihtoveron lisävero 65

M

makeisvero 27, 72

matkustajavero 66, 166

moottoriajoneuvovero 51,79

moottoripyörien ajoneuvovero 85

moottoripyörävero ks. autovero

P

pelikorttivero 22,50

perustuslaki $82,105,125,142$, $156,158,177$

pistevero 14

polttoainemaksu $44,71,81$

polttoainevero $41,71,76,110$, $122,130,145,158,181$

R

ratamaksu ja -vero 50,82

ravintorasvavero 33

rehuvero 37 
Asiahakemisto

S

sokerivero 32

sotavero 24,172

sähkövero 45,72

T

telefoonivero 23

televero 69, 111

tilauslentovero 67

tulitikkuvero 26

tulli $14,18,24,69$

tulovero 171

tupakkavero $16,20,25,70$

\section{V}

vakuutusmaksuvero 65

varallisuusverot 167

venevero 85

virvoitusjuomavero 28,72

väylämaksu 50, 82

$\mathbf{Y}$

yhdenvertaisuus ks. perustuslaki

ylellisyysvero $5,17,25,30,50$,

$122,154,156,170$ 